\title{
Alaska's Mineral Industry 1999
}

\section{SPECIAL REPORT 54}

Division of Geological \& Geophysical SuRveys in cooperation with 


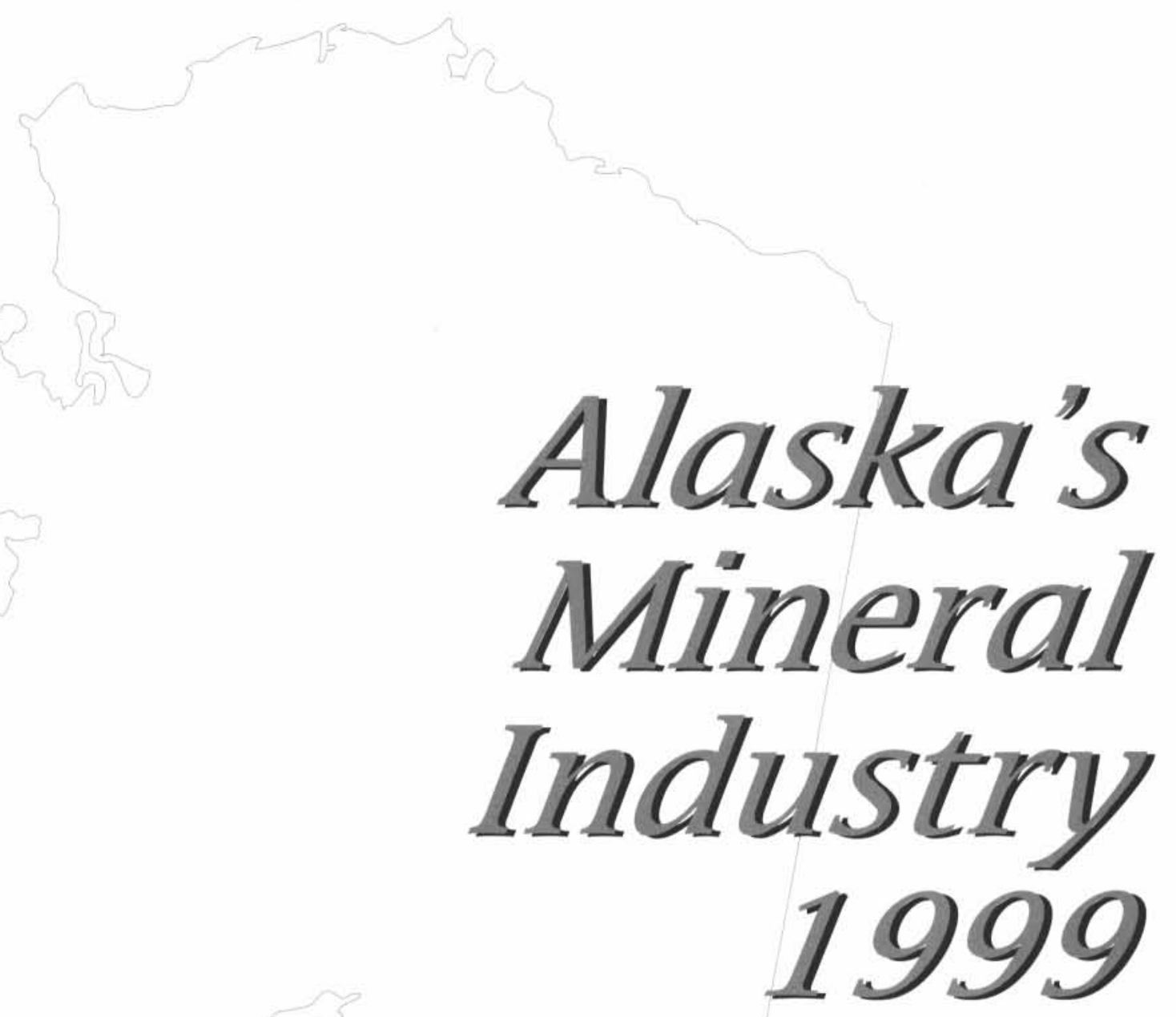

by

R.C. Swainbank, D.J. Szumigala, M.W. Henning, and F.M. Pillifant

Division of Geological \& Geophysical Surveys

SPECIAL REPORT 54 


\section{EXECUTIVE SUMMARY}

Alaska's Mineral Industry 1999, Special Report 54, is the 19th annual report produced jointly by the Departments of Natural Resources and Community and Economic Development through their Divisions of Geological \& Geophysical Surveys (DGGS) and Community \& Business Development (DCBD), respectively.

Despite record low prices for several metals, the total value of Alaska's mineral industry, including exploration and development investments and the value of the production, was $\$ 1.119$ billion. This is an 8 percent increase from the previous year, and only 4 percent below the previous record of $\$ 1.162$ billion in 1997. Of this total, $\$ 52.3$ million was invested in exploration, $\$ 33.8$ million in development projects, and the products were valued at $\$ 1.033$ billion, of which $\$ 921$ million consisted of metals.

Exploration expenditures in Alaska in 1999 declined 9 percent to $\$ 52.3$ million from $\$ 57.3$ million in 1998 , but much larger declines were seen in most other areas of the world. Most of these investments were in the eastern interior region of the state, where gold exploration in the region between Fairbanks and the Pogo deposit north of Delta Junction continued at a robust level. The gold resource at Pogo increased 8 percent to 5.6 million ounces following the 1999 drilling program, and an exploration adit was driven about 3,000 feet under the upper of the two major zones. In the Fairbanks district Kinross Gold had a busy season exploring for mill-feed near Fort Knox mine and at the Gil, Ryan Lode, and True North properties. There was also renewed interest in the northern region following the discovery by Cominco of a major new deep zinc-lead-silver deposit north of the Red Dog Mine, and a \$9 million exploration program is scheduled for the 2000 season. Other areas of the state with active 1999 exploration programs included the Seward Peninsula, the Circle district, the Haines area, and near Greens Creek Mine. Exploration for platinum-group metals increased during 1999 in response to record high prices for platinum, palladium, and rhodium. Most of the activity was in the Alaska Range, but some of the known occurrences in southeastern Alaska were also examined.

About 12,793 state mining claims and 1,892 prospecting sites (7,568 claim-equivalents) were staked in 1999 , as well as 308 federal mining claims. Most of the activity was near Red Dog Mine and in the Big Delta area west of the Pogo deposit.

Development expenditures in 1999 were $\$ 33.8$ million, down 39 percent from the $\$ 55.4$ million in 1998 , mainly due to the completion of the Production Rate Increase (PRI) project at the Red Dog Mine. Substantial investments were made by Kinross in the Fairbanks district, by Coeur Alaska at Kensington Mine north of Juneau, and by Kennecott/ Hecla at Greens Creek Mine. Development projects planned for 2000 suggest that there will be a substantial increase in investment.

Record production of zinc and lead concentrates at Red Dog and Greens Creek mines in 1999 (along with higher base-metal prices) served to offset the decline in both hardrock and placer gold production. During the year the underground Nixon Fork gold mine closed, and the open-pit Illinois Creek hardrock mine was on care-and-maintenance status. There was no production from the major placer mine at Nome, recently acquired by NovaGold Resources, and several small placer mines did not operate due to low gold prices. Nevertheless, the value of production was $\$ 1,032.9$ million, of which $\$ 921$ million (89 percent) was for metals, and zinc accounted for fully 68 percent of the metal value, or 61 percent of all production. Gold, long the mainstay of Alaska's industry, accounted for about 16 percent of the metal production, or 14 percent of all production. Coal production increased in 1999, as did rock production, but there was a slight decline in the production of sand and gravel.

Alaska's mineral industry provided an estimated 3,166 full-time equivalent jobs in 1999, down 9 percent from the previous year. Most of the decline was in mineral exploration and placer mining.

In 1999 DGGS contracted for an airborne geophysical survey of about 1,000 square miles west and north of Pogo, and for the first time added radiometric equipment to complement the standard magnetic and electromagnetic surveys. As in past years the announcement of the pending survey led to additional land acquisition by several mining companies. A DGGS team began geologic ground-truth mapping of the Fortymile area following the airborne geophysical surveys of 1998 and a joint effort by the U.S. Geological Survey and the state Division of Mining, Land \& Water continued baseline water-quality studies in the Fortymile and Goodpaster drainages. Cominco Alaska received the Governor's Exporter of the Year award for 1999, and Wayne Gibson received the Governor's Reclamation Award for his work on Golden Creek in the Melozitna district. Revenues to the State of Alaska and to several municipalities increased from $\$ 14.8$ million in 1998 to $\$ 16.9$ million in 1999. 


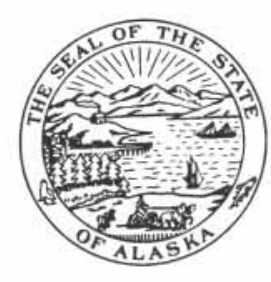

STATE OF ALASKA

Tony Knowles, Governor

\title{
DEPARTMENT OF COMMUNITY \& ECONOMIC DEVELOPMENT
}

Deborah B. Sedwick, Commissioner

\author{
DIVISION OF COMMUNITY \& BUSINESS DEVELOPMENT \\ Pat Poland, Director
}

DEPARTMENT OF NATURAL RESOURCES

Pat Pourchot, Commissioner

\author{
DIVISION OF GEOLOGICAL \& GEOPHYSICAL SURVEYS \\ Milton A. Wiltse, Director and State Geologist \\ DIVISION OF MINING, LAND \& WATER \\ Bob Loeffler, Director
}

DGGS publications may be inspected at the following locations. Address mail orders to the Fairbanks office.
Alaska Division of Geological
\& Geophysical Surveys
ATTN: Geologic Communications
794 University Avenue, Suite 200
Fairbanks, Alaska 99709-3645
Elmer E. Rasmuson Library
University of Alaska Fairbanks
Fairbanks, Alaska 99775-1005

\author{
University of Alaska Anchorage \\ Library \\ 3211 Providence Drive \\ Anchorage, Alaska 99508
}

\begin{abstract}
Alaska Resource Library
3150 C Street, Suite 100

Anchorage, Alaska 99503
\end{abstract}

Alaska State Library

State Office Building, 8th Floor

333 Willoughby Avenue

Juneau, Alaska 99811-0571

\footnotetext{
Publication of this report is required by Alaska Statute 41 "to determine the potential of Alaska land for production of metals, minerals, fuels, and geothermal resources; the location and supplies of groundwater and construction materials; the potential geologic hazards to buildings, roads, bridges, and other installations and structures; and shall conduct such other surveys and investigations as will advance knowledge of the geology of Alaska."

NOTE: Mention of any company or brand name does not constitute endorsement by any branch or employee of the State of Alaska.
} 


\section{GOVERNOR'S FOREWORD}

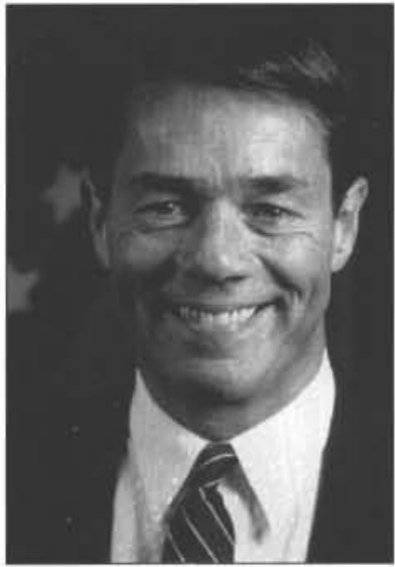

Boosted by record production, Alaska's minerals industry had another outstanding year in 1999 , with a total value of almost $\$ 1.12$ billion, the second highest on record and the fourth billion dollar year in a row. Alaska's mining industry continues to be a major factor in our state's increasingly diversified economy.

Increased production from Alaska's largest mines helped offset low prices for several metals last year. Of the industry's total value of $\$ 1.119$ billion, production accounted for a record $\$ 1.033$ billion, of which $\$ 921$ million was from metals. 1999 was the first year in Alaska's history that production alone topped the billion-dollar mark. Investment in exploration accounted for $\$ 52.3$ million of the industry's overall value and $\$ 33.8$ million was spent on development projects.

Record production of zinc and lead concentrates at Red Dog and Greens Creek mines in 1999, combined with higher base-metal prices, offset declines in both hard-rock and placer gold production. The value of production easily topped the previous high of $\$ 936.2$ million in 1997.

In all, Alaska's mineral industry provided almost 3,200 high paying, full-time jobs for Alaskans. While that number was down from the previous year, mainly due to the temporary closure of placer mining operations, interest in Alaska's mineral wealth remains strong. The Fraser Institute, Canada's leading economic think tank, ranked Alaska among the top ten locations in North America for overall investment attractiveness.

Spending on exploration during 1999 declined 9 percent to $\$ 52.3$ million, but larger declines were seen in other mining regions of the world. Exploration investments were primarily in the eastern interior region of the state where gold exploration in the region between Fairbanks and the Pogo deposit north of Delta Junction continued at a robust level. The gold resource at Pogo increased 8 percent to 5.6 million ounces following the 1999 drilling program, and an exploration adit was driven about 3,000 feet under the upper of the two major zones. There was also renewed interest in the northern region following the discovery by Cominco of a major new deep zinc-lead-silver deposit north of the Red Dog Mine.

The State of Alaska continues to be a partner in encouraging mining development. The Division of Geological \& Geophysical Surveys continued their programs to provide detailed information on Alaska's geologic framework. Airborne geophysical surveys and related field programs help point the way to future exploration and development.

The year 1999 continued to be a healthy one for Alaska's mining industry. While challenges to the industry remain, the State of Alaska plans to continue its support and encouragement for this important sector of Alaska's economy.

Governor Tony Knowles 


\section{COMMISSIONERS' FOREWORD}

Although exploration investment worldwide continued to decline, Alaska was almost immune, with only a slight reduction in exploration in 1999. Highlights included a major new discovery of zinc north of Red Dog, continued excitement at and around the Pogo gold discovery and the Fort Knox Mine near Fairbanks, and greater interest in the platinum-group metals.

The \$1.033 billion value of production for 1999 was over \$100 million greater than for the previous year, mainly due to the increased production of zinc at Red Dog and Greens Creek, and of coal at Usibelli Coal Mine at Healy. Much of the coal, and all of the lead, zinc, and silver is exported, so with the recovery of the world economy, the future looks bright.

With recent reorganization within the Department of Community \& Economic Development, we will be better able to define the aspirations of many of the rural communities, and help diversify the local economies. We expect that in many instances mining will play as much of a role as it does in northwest Alaska.

\section{Deborah B. Sedwick, Commissioner, Department of Community \& Economic Development}

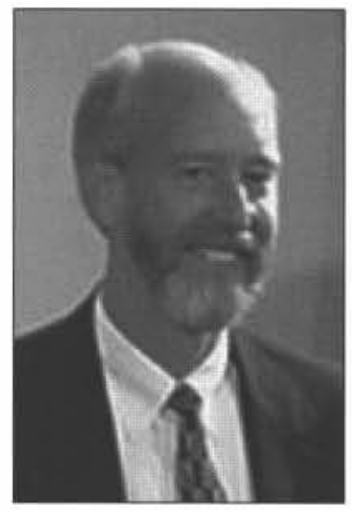

1999 was again a year of challenge for Alaska's mineral industry. Metal prices rebounded early in the year only to fall back to lower levels. Despite the relatively low prices industry interest in state mineral land continued to be strong.

Alaska continued to experience robust exploration activity, bucking a worldwide downturn in mineral exploration of 20 to 30 percent. During 1999, approximately $\$ 52.3$ million was spent on exploration in Alaska. Roughly 70 percent of these expenditures occurred in the eastern interior region. The Goodpaster mining district was the hub of activity as companies conducted exploration programs on claims staked around the Pogo property.

The Department of Natural Resources (DNR) and the U.S. Geological Survey (USGS) also focused research efforts in the eastern interior region. Geologists from the DNR Division of Geological \& Geophysical Surveys began investigations in the Fortymile area to follow up the 1998 airborne survey of this area. Baseline water geochemical sampling and a geological mapping program in the Fortymile and Goodpaster River watersheds were conducted.

In northwestern Alaska, the discovery by Cominco Alaska Inc. of a large, flat-lying zinclead-silver deposit 6 miles north of Red Dog Mine continues to define this district as one of the world's premier lead-zinc districts. This discovery on state land further validates the state's selection decisions. More than 6,000 new state mining claims were staked to cover the new deposit. On the Seward Peninsula, DNR offered 28 offshore mining lease tracts near Nome for competitive bid.

DNR's e-commerce efforts have focused on streamlining the annual placer mining permitting process, an effort that will speed up permit issuance. State land status plats are now available on line thanks to the efforts of the DNR Lands Records Information Section. Check it out at http://www.dnr.state.ak.us/landrecords.

The mining industry will continue to be a major player in the diversification of the rural economy whether the development occurs on state lands, patented mining claims, or Alaska Native corporation lands. The mineral industry will continue to be a vital player in helping to improve the rural standard of living and create employment opportunities for Alaska's rural residents. We at DNR will continue to help foster this relationship with rural Alaska and the mineral industry while maintaining a pro-active stewardship of Alaska's public lands.

Pat Pourchot, Commissioner, Department of Natural Resources 


\section{CONTENTS}

Executive Summary .......................................................................................................................................... i

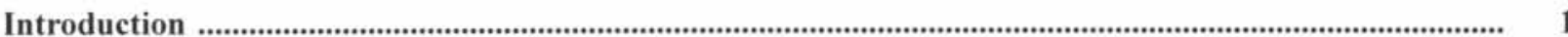

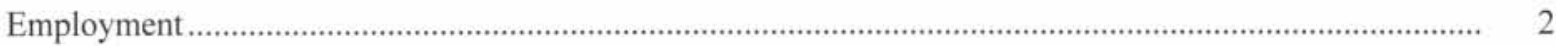

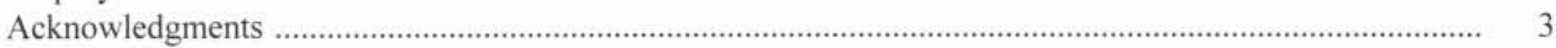

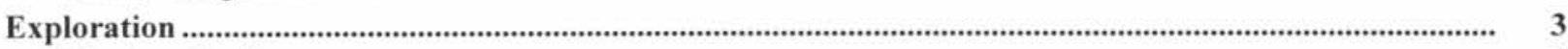

Northern Region ................................................................................................................................

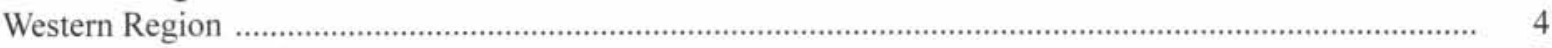

Eastern Interior Region ..................................................................................................................... 8

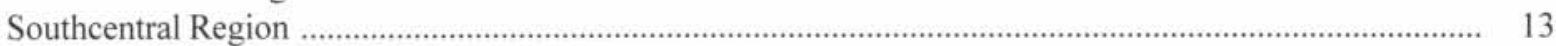

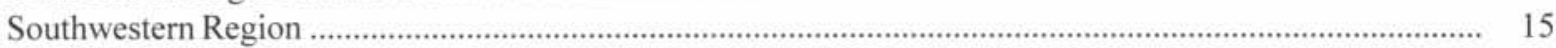

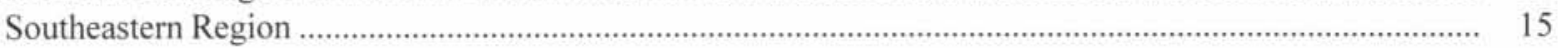

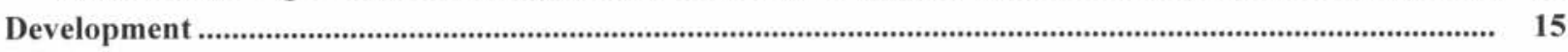

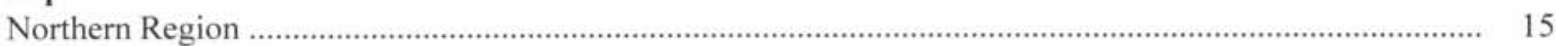

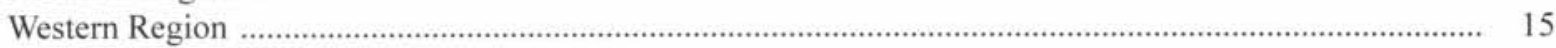

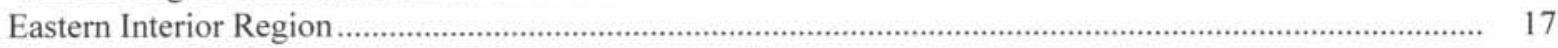

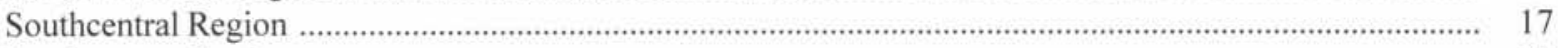

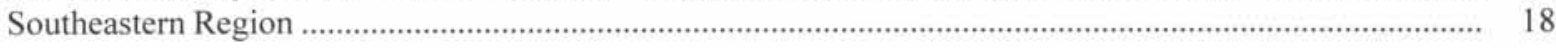

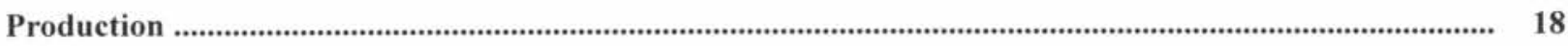

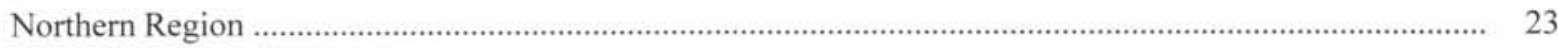

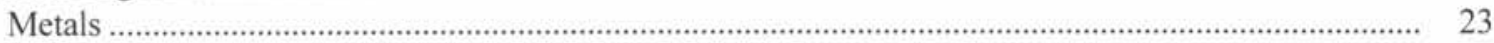

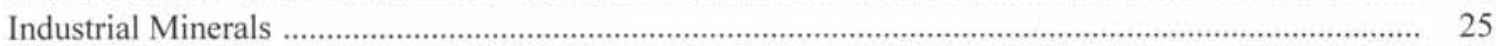

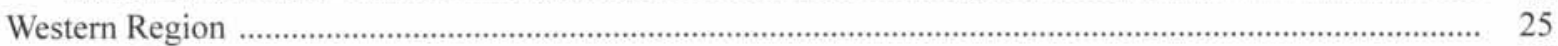

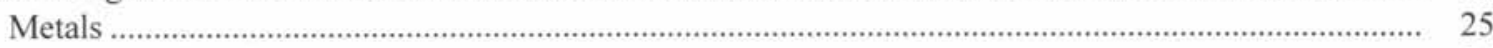

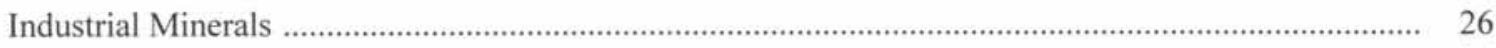

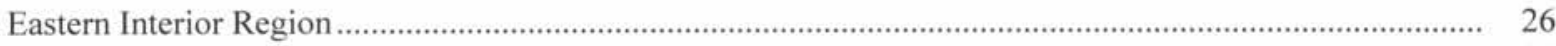

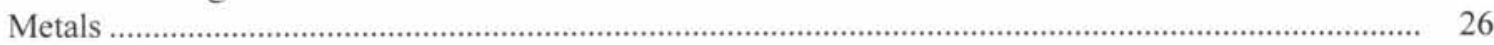

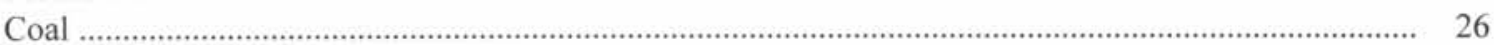

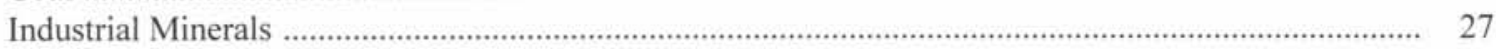

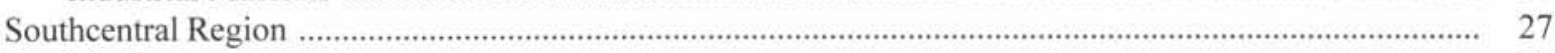

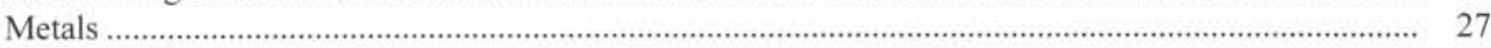

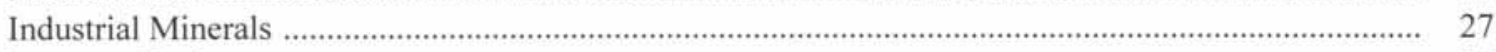

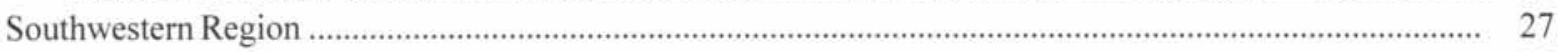

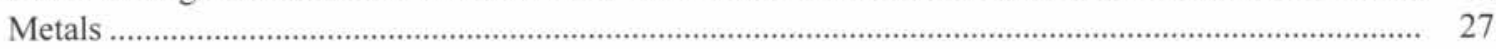

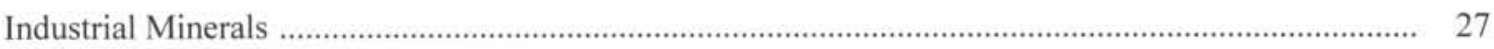

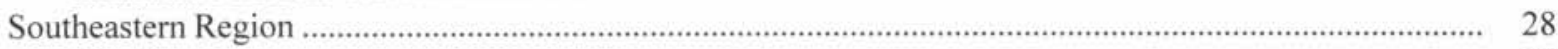

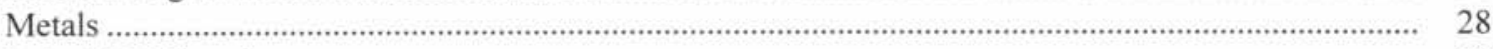

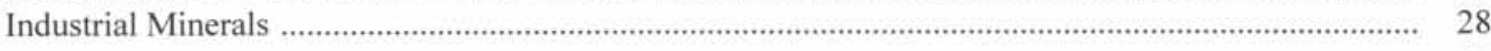

Drilling …...................................................................................................................................................... 28

Government Actions ................................................................................................................................... $\quad 30$

Appendixes

A. New claims staked in Alaska, 1995-99 ........................................................................................ 33

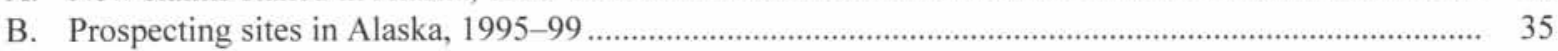

C. Mining licenses issued by and received from the Alaska Department of Revenue ................................. 37

D. Selected significant mineral deposits and mineral districts in Alaska ..................................................... 50

E. State and federal agencies and private interest groups involved in mineral

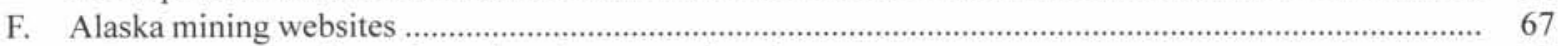

G. U.S. customary units and metric units conversion chart ....................................................................... 69

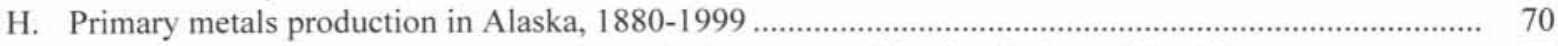

I. Production of industrial minerals, coal, and other commodities in Alaska, 1880-1999 ....................... 72 


\section{CONTENTS}

Figures

1. Graph showing exploration and development expenditures and the value of production

of Alaska mineral industry, 1981-99

2. Chart showing 1999 mineral industry employment by category

3. Map showing regions of mineral activity in Alaska as described in this report

4. Chart illustrating 1999 exploration expenditures by commodity

5. Map showing selected mineral exploration projects in Alaska, 1999

6. Photo showing core drilling for gold mineralization on the Fred Creek prospect at Mt. Distin .........................

7. Photo showing work on the face in the Pogo decline

8. Photo showing composite of the Liese $1 \frac{1}{2}$ vein, a newly discovered vein exposed in the Pogo decline

9. Photo showing early construction of Pogo decline and portal facilities. 10

10. Photo showing Era helicopter landing at American Copper \& Nickel Co. drill site on south face of Tiger Mountain

11. Photo showing Era helicopter performing an airborne geophysical survey 12

12. Map showing selected mineral development projects in Alaska, 1999

13. Graph showing sand and gravel production in Alaska, 1950-99

14. Graph showing amount and value of gold production in Alaska, 1880-1999

15. Graph showing coal production in Alaska, 1915-99, including exports to Korea

16. Map showing selected production projects, 1999

17. Photo showing aerial view of the Main Deposit pit and support facilities at Red Dog Mine

18. Photo showing rock being loaded onto a barge bound for Dillingham

19. Photo showing view of ore processing facilities at Kinross Gold Corp.'s Fort Knox Mine

20. Photo showing view of office, shop, and milling complex at Fort Knox Mine

21. Photo showing work on TJ Enterprises reverse-circulation drill rig

22. Photo showing underground drilling station in Pogo decline

23. Photo showing inflatable kayak beached on gravel bar along Dennison Fork of the Fortymile River ..

24. Photo showing reclamation of Golden Creek in the Melozitna mining district

25. Photo showing reclamation of Golden Creek in the Melozitna mining district 1 2 


\section{CONTENTS}

Tables

1. Total value of the mineral industry in Alaska by year (in millions of dollars) ........................................

2. Estimated Alaska mine employment, $1992-99$............................................................................. 2

3. Reported exploration expenditures and employment in Alaska, 1999 ................................................. 4

4. Reported exploration expenditures in Alaska by commodity, 1982-99 …........................................... 5

5. Summary of claim activity, 1984-99 ………............................................................................

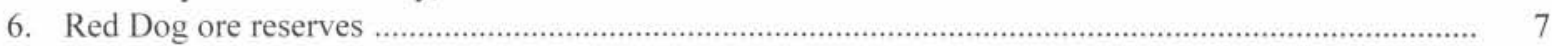

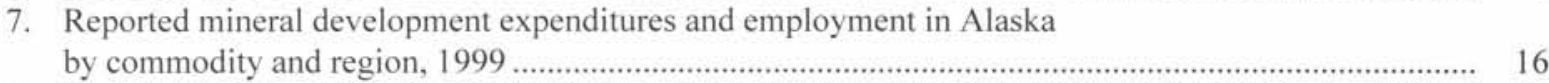

8. Reported mineral development expenditures in Alaska by commodity, 1982-99 _............................... 16

9. Estimated mineral production in Alaska, 1997-99 …...................................................................... 18

10. Companies and individuals reported to be producing metal in Alaska, 1999 ........................................ 19

11. Average metal prices, 1993-99 …………............................................................................... 22

12. Reported refined gold production, number of operators, and industry employment, 1997-99 ............... 23

13. Production for selected Alaska placer gold mines, $1993-99$............................................................. 23

14. Reported sand and gravel production and industry employment in Alaska by region, 1999 ................. 24

15. Reported rock production and industry employment in Alaska by region, 1999 ................................... 24

16. Cominco Alaska's Red Dog Mine production statistics, 1989-99 ....................................................... 25

17. Fort Knox Gold Mine production statistics, 1996-99 …….................................................................... 26

18. Greens Creek Mine production statistics, 1989-99 ………….......................................................... 28

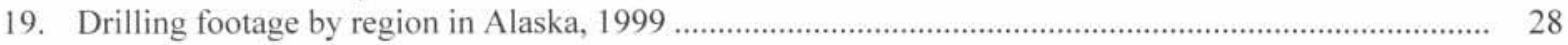

20. Drilling footage reported in Alaska, 1982-99 ............................................................................... 29

21. Companies reporting significant drilling programs in Alaska, 1999 ................................................. 29

22. Revenues paid to the State of Alaska and municipalities by Alaska's mineral industry, 1994-99 .......... 30

23. Table of airborne geophysical survey work contracted by DGGS ...................................................... 


\section{Alaska's Mineral Industry I 999}

R.C. Swainbank, ${ }^{1}$ D.J. Szumigala, ${ }^{2}$ M.W. Henning, ${ }^{3}$ and F.M. Pillifant ${ }^{4}$

\section{INTRODUCTION}

This summary of the 1999 Alaska mineral industry is made possible by information provided through replies to questionnaires mailed by the Alaska Division of Geological \& Geophysical Surveys (DGGS), phone interviews, press releases, and other information sources. Funding for production of the report is provided by the Division of Community \& Business Development (DCBD) in the Department of Community \& Economic Development (DCED). This report is part of a cooperative venture between DGGS in the Department of Natural Resources (DNR), the DCBD, and the Division of Mining, Land \& Water (DMLW) of DNR. This report for the 1999 calendar year is the 19th of the series.

Figure 1 and table 1 show the estimated value of the mineral industry for each year since 1981, divided into exploration and development investments, and the value of the mined products. As in past years, we rely on company information to define the exploration and development parameters. Average metal prices are calculated from the weekly average spot prices on the London Metal Exchange, and are used
Table 1. Total value of the mineral industry in Alaska by year (in millions of dollars)

\section{Exploration Development Production (expenditure) (expenditure) (value) Total}

\begin{tabular}{lrrrr}
1981 & $\$ 76.0$ & $\$ 26.4$ & $\$ 188.6$ & $\$ \mathbf{2 9 1 . 0}$ \\
1982 & 45.0 & 41.6 & 196.4 & $\mathbf{2 8 3 . 0}$ \\
1983 & 34.1 & 27.8 & 232.4 & $\mathbf{2 9 4 . 3}$ \\
1984 & 22.8 & 53.6 & 199.4 & $\mathbf{2 7 5 . 8}$ \\
1985 & 9.2 & 34.1 & 226.6 & $\mathbf{2 6 9 . 9}$ \\
1986 & 8.9 & 24.3 & 198.5 & $\mathbf{2 3 1 . 7}$ \\
1987 & 15.7 & 100.3 & 202.4 & $\mathbf{3 1 8 . 4}$ \\
1988 & 45.5 & 275.0 & 232.2 & $\mathbf{5 5 2 . 7}$ \\
1989 & 47.8 & 134.3 & 277.0 & $\mathbf{4 5 9 . 1}$ \\
1990 & 63.3 & 14.3 & 533.0 & $\mathbf{6 1 0 . 6}$ \\
1991 & 39.9 & 25.6 & 546.5 & $\mathbf{6 1 2 . 0}$ \\
1992 & 30.2 & 30.0 & 560.8 & $\mathbf{6 2 1 . 0}$ \\
1993 & 30.3 & 27.7 & 448.7 & $\mathbf{5 0 6 . 7}$ \\
1994 & 31.1 & 44.9 & 507.5 & $\mathbf{5 8 3 . 5}$ \\
1995 & 34.3 & 148.6 & 537.2 & $\mathbf{7 2 0 . 1}$ \\
1996 & 44.6 & 394.0 & 590.4 & $\mathbf{1 , 0 2 9 . 0}$ \\
1997 & 57.8 & 168.4 & 936.2 & $\mathbf{1 , 1 6 2 . 4}$ \\
1998 & 57.3 & 55.4 & 920.2 & $\mathbf{1 , 0 3 2 . 9}$ \\
1999 & 52.3 & 33.8 & $1,032.9$ & $\mathbf{1 , 1 1 9 . 0}$ \\
& & & & $\mathbf{1 , 1}$ \\
TOTAL & $\$ \mathbf{S 7 4 6 . 1}$ & $\mathbf{\$ 1 , 6 6 0 . 1}$ & $\mathbf{\$ 8 , 5 6 6 . 9}$ & $\mathbf{\$ 1 0 , 9 7 3 . 1}$ \\
\hline
\end{tabular}

SOURCE: Alaska's mineral industry reports published annually by DGGS.

Figure 1. Alaska's mineral industry total value, 1981-99.

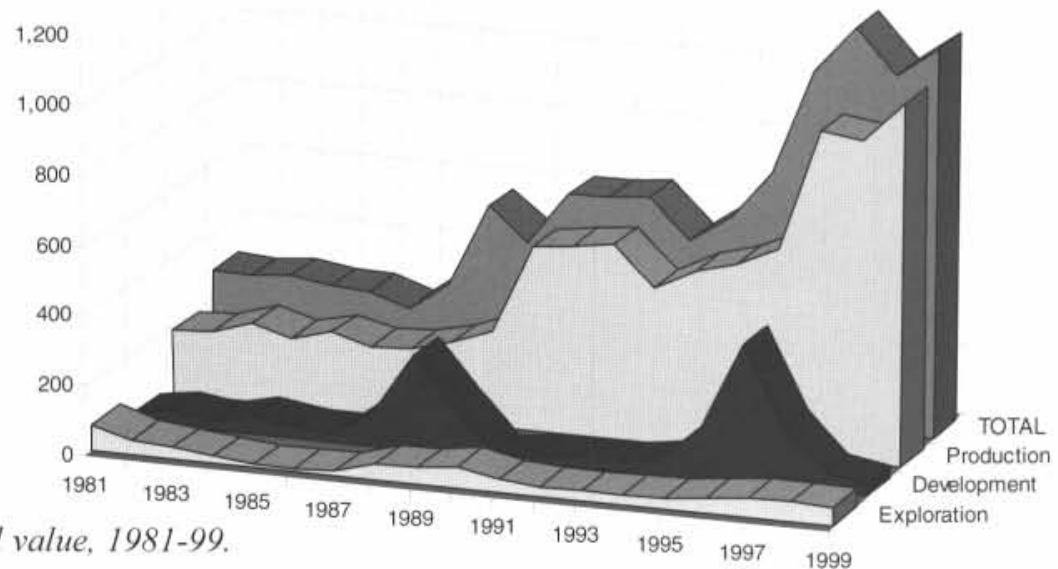

\footnotetext{
'Alaska Division of Community \& Business Development, Unit \#7, 3677 College Road, Fairbanks, Alaska 99709-3732.

${ }^{2}$ Alaska Division of Geological \& Geophysical Surveys, 794 University Avenue, Suite 200. Fairbanks, Alaska 99709-3645.

${ }^{3}$ Alaska Division of Mining, Land \& Water, 550 W. 7th Avenue, Suite 900B. Anchorage, Alaska 99501-3577.

${ }^{4}$ Alaska Division of Community \& Business Development, PO Box 110809, Juneau, Alaska 99811-0809.
} 
to calculate the value of production. Forward sales at higher-than-spot prices are used if reported by a company. These values do not take into account the costs of mining and transportation, or smelter charges and penalties.

Mining companies sometimes report in metric units, but this report uses only U.S./English units. A conversion table is provided in Appendix G. In some instances values are reported as parts per million or parts per billion, reflecting industry standards. Whenever possible, values for gold and silver have been translated to ounces per ton, unless the translation would render the numbers insignificant.

The 1999 cumulative value of the Alaska minerals industry is $\$ 1.119$ billion, an 8 percent increase compared with $\$ 1.033$ billion in 1998 , and only 4 percent less than the record $\$ 1.162$ billion in 1997 . Record metal production (\$921.2 million in 1999 versus $\$ 814.4$ million in 1998) was offset by a decline in both exploration ( $\$ 52.3$ million in 1999 versus $\$ 57.3$ million in 1998) and development ( $\$ 33.8$ million in 1999 versus $\$ 55.4$ million in 1998) (table 1; fig. 1). Record production of zinc from both Red Dog and Greens Creek mines ( $\$ 630.8$ million in 1999 versus $\$ 505.4$ million in 1998) more than compensated for the lower value of gold production ( $\$ 144.3$ million in 1999 versus $\$ 174.6$ million in 1998). Fort Knox Mine near Fairbanks is Alaska's largest gold producer with an average daily production of approximately 1,000 ounces of gold.

\section{EMPLOYMENT}

The estimated total employment by the Alaska mineral industry was 3,166 full-time-equivalent jobs (table 2; fig. 2). This is a decline of 311 ( 9 percent) from the 3,477 jobs

Table 2. Estimated Alaska mine employment, 1992-99a

\begin{tabular}{|c|c|c|c|c|c|c|c|}
\hline & 1993 & 1994 & 1995 & 1996 & 1997 & 1998 & 1999 \\
\hline \multicolumn{8}{|l|}{ Gold/silver mining } \\
\hline Placer & 1,205 & 1,150 & 975 & 825 & 780 & 710 & 591 \\
\hline Lode & N/A & .. & 38 & 138 & 415 & 345 & 296 \\
\hline Polymetallic & 26 & -. & - & 68 & 230 & 275 & 275 \\
\hline Base metals & 376 & 311 & 397 & 407 & 478 & 466 & $549^{b}$ \\
\hline Recreational & 270 & 280 & 255 & 260 & 270 & 255 & 240 \\
\hline Sand \& gravel & 580 & 640 & 577 & 598 & 700 & 658 & 590 \\
\hline Rock & 205 & 210 & 200 & 149 & 123 & 121 & 128 \\
\hline Coal & 109 & 115 & 120 & 115 & 118 & 128 & 121 \\
\hline Peat & 49 & 55 & 30 & 38 & 42 & 40 & 38 \\
\hline $\begin{array}{l}\text { Tin, jade, soapstone, } \\
\text { ceramics, platinum }\end{array}$ & 20 & 25 & 20 & 20 & 20 & 20 & 20 \\
\hline Mineral development & 132 & 115 & 637 & 862 & 409 & 177 & 135 \\
\hline Mineral exploration & 164 & 182 & 157 & 257 & 277 & 282 & 183 \\
\hline TOTAL & 3,136 & 3,083 & 3,406 & 3,737 & 3,862 & 3,477 & 3,166 \\
\hline
\end{tabular}

Production Employment

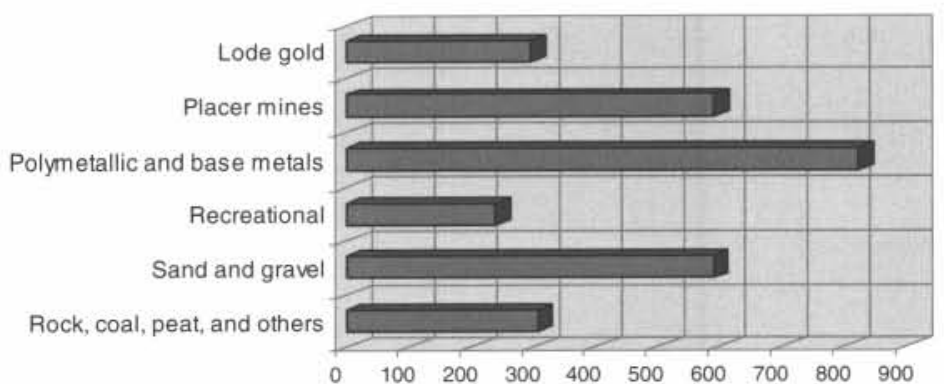

1999 Total: 3,166 full-time-equivalent jobs

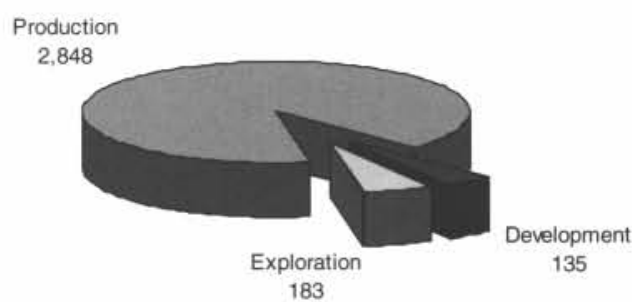

Figure 2. 1999 mineral industry employment by category. 
in 1998. Most of the decline was in the precious metals sector, with the closure of the large placer gold mine at Nome, and the hardrock mines at Nixon Fork near McGrath and Illinois Creek Mine near Galena. There was a 23 percent drop in mineral development jobs and a 33 percent drop in mineral exploration jobs from 1998 to 1999.

\section{ACKNOWLEDGMENTS}

This report on the Alaska mineral industry is designed to provide current, accurate, and technically reliable information. The authors wish to thank all companies, agencies, and individuals who responded to questionnaires or phone calls, and provided information about their activities and operations. Without your voluntary and timely information this report would not be possible.

DGGS mailed approximately 1,000 questionnaires in November 1999, and received 187 replies. Dick Swainbank (DCBD) and Dave Szumigala (DGGS) prepared the body of the text, tables, and appendices with the assistance of Frankie Pillifant (DCBD) and Mitch Henning (DMLW).

The cover design is by Joni Robinson, and graphic illustrations are by Alfred Sturmann and Joni Robinson. Paula Davis edited the final version, and Joni Robinson completed the layout and design. Publication was made possible by funds from the Division of Community \& Business Development.

\section{EXPLORATION}

Estimated minimum exploration expenditures throughout Alaska during 1999 were $\$ 52.3$ million, down 9 percent from the $\$ 57.3$ million invested in 1998. Alaska's exploration sector fared quite well, considering the massive reductions (20-25 percent) in exploration budgets worldwide. Figure 3 shows the regions of the state used in this and subsequent sections. Expenditures and employment figures by commodity and region are listed in table 3 . Exploration expenditures in Alaska by commodity for the past 18 years are listed in table 4 . Figure 4 is a graphical representation of exploration expenditures by commodity. Figure 5 shows the location of significant exploration projects in Alaska during 1999. Sixty-nine percent of exploration expenditures were spent in the eastern interior region of Alaska. The Goodpaster mining district was the hub of exploration activity as companies conducted initial exploration programs on claims staked around the Pogo property in 1998.

About 12,793 new state mining claims, 1,892 new state prospecting sites $(7,568$ claim-equivalents), and 308 new federal claims were staked in Alaska in 1999. An additional 2,060 prospect sites ( 8,240 claimequivalents) were extended for another year. Table 5 summarizes the number of claims staked and current from 1984 through 1999. It has been modified to account for new data generated by the Department of Natural Resources' Land Records Information Section. Most of the claim staking (appendixes A and B) was north of the Red Dog Mine and in the area between Fairbanks and Big Delta, and the majority of the prospecting sites were to the east of Fairbanks.

\section{NORTHERN REGION}

Cominco Alaska Inc. had a large diamond drill program in 1999 and announced a new large, flat-lying zinc-lead-silver deposit, named Anarraaq, located about six miles north of Red Dog Mine. The discovery of Anarraaq was the result of an integrated geophysical and geologic effort and it is the first high-grade discovery outside of the Red Dog mineral system. Drill intercepts up to 240 feet thick with 20 percent zinc and 5 percent lead were found at approximately 2,200 feet below the surface in holes spaced between 800 and 900 feet apart. Mineralization is open in all directions except to the southeast. Eight of nine core holes drilled to target depth intersected significant massive sulfide mineralization. Two holes were

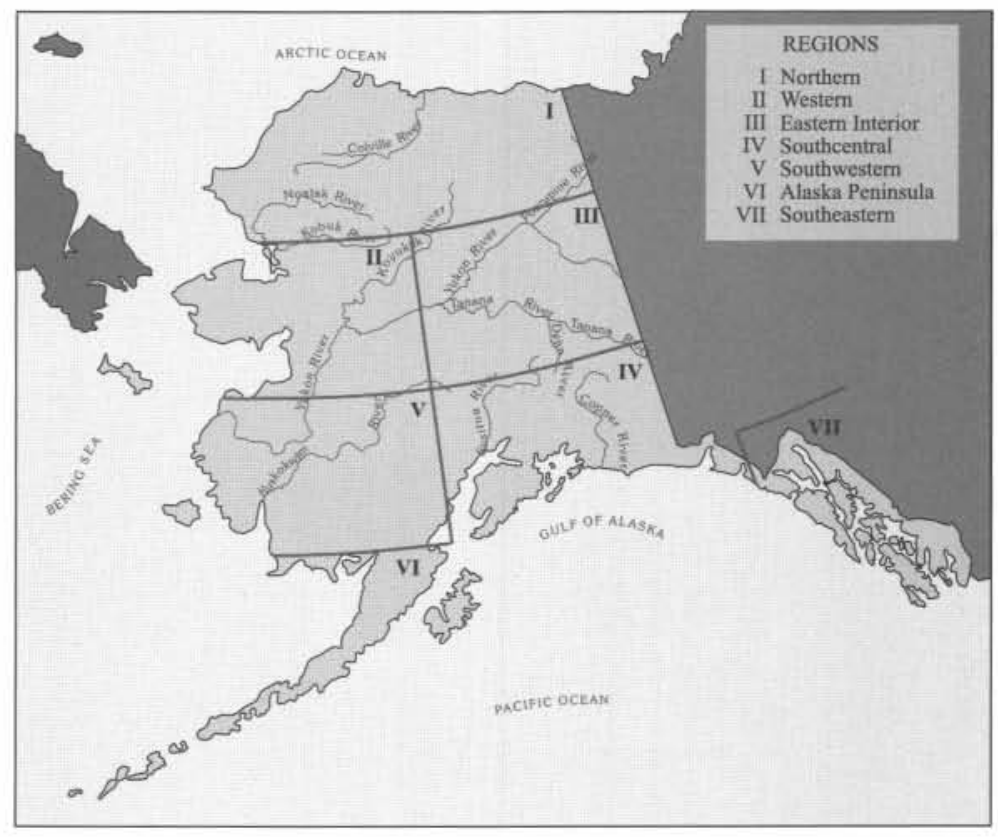

Figure 3. Regions of mineral activity in Alaska as described in this report. 
stopped short of target depth and will be completed next year. Best mineralized intercepts include 30 percent zinc and 6 percent lead between 2,227 and 2,280 feet in hole $806 ; 15$ percent zinc and 5 percent lead between 2,182 and 2,202 feet in hole $808 ; 18$ percent zinc and 5 percent lead between 2,229 and 2,459 feet in hole 809; and 20 percent zinc, 5 percent lead, and 4 ounces per ton silver between 2,160 and 2,400 feet in hole 810 .

The Anarraaq deposit lies within a large, 2 milligal gravity anomaly that defines the areal extent of a large (over 1 billion tons) barite body overlying the deposit. The barite and sulfides are separated by a thrust fault and 300 feet of barren shale. Mineralization consists of banded to massive sphalerite, galena, and pyrite. A preliminary interpretation of the Anarraaq mineralization by Cominco suggests the possibility of 13.2 million tons grading 18 percent zinc, 5 percent lead, and 2.89 ounces of silver per ton. Anarraaq is slightly lower grade than the main Red Dog ore body, but it will increase the grade of total ore reserves in the Red Dog area (table 6). The new discovery occurs on state-owned lands, unlike the present mine that is located on NANA Regional Corp. (First Nation) lands. Over 6,000 new state mining claims were staked to cover this potential new deposit that would need to be mined from an underground facility.

In addition to the Anarraaq discovery, Cominco's regional exploration program identified several other attractive drill targets. Additional exploration drilling is expected to outline the Anarraaq deposit and search for additional deposits within the region. Cominco is also considering drilling to evaluate the potential for natural gas in shale deposits near Red Dog Mine. Cost savings from using natural gas instead of imported diesel could make marginal deposits profitable and reduce environmental risks.

Kennecott Minerals continues to evaluate the Bornite and Arctic deposits in the Ambler mineral belt. Drilling results at Arctic in 1998 were encouraging, and a new geologic model suggests that mineralization extends deeper. No work was done in 1999, but the company is considering the possibility of developing Arctic as an open-pit and underground mine. Lack of access to transportation remains the key problem to making Bornite and Arctic viable mining operations.

\section{WESTERN REGION}

Exploration was quite active on the Seward Peninsula during 1999. NovaGold Resources Inc. drilled the Anvil Creek area north of Nome in a $\$ 500,000$ program funded by Kennecott Exploration Co. in a region with more than 3 million ounces of historic placer gold production. Rich placer production from Anvil Creek overlies a flexure in a major structural feature - the Anvil Creek shear zone. The shear zone is coincident with quartz-carbonate-sulfide stockwork veins and pervasively silicified schist along the valley bottom. At least 7,000 feet of reverse-circulation drilling was completed in 32 holes. Drill intercepts included multiple 5 -foot intervals averaging up to 0.277 ounces per ton gold, with northwest-trending drill fences spaced from 2,000 to 4,000 feet apart. Kennecott withdrew from the joint-venture agreement after drilling results did not meet expectations.

NovaGold optioned part of its Rock Creek gold deposit nearby to Viceroy Resource Corp. and continued to

Table 3. Reported exploration expenditures and employment in Alaska, 1999

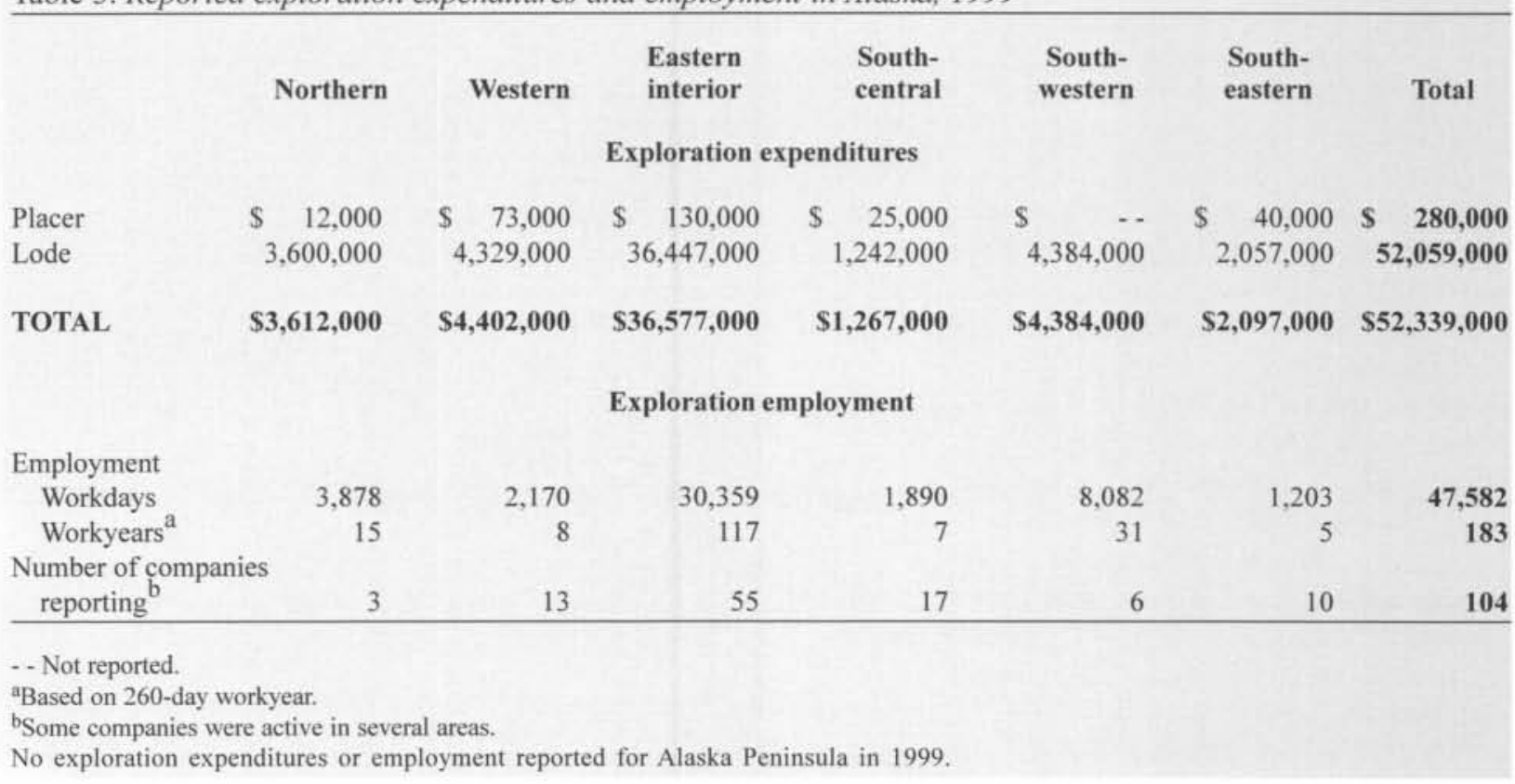


act as operator on the project. A six-hole reverse-circulation drilling program included twinning previous holes and the recent results are 59 percent higher than previous results. Other highlights from the drilling include intercepts of 135 feet with 0.07 ounces per ton gold (including 40 feet with 0.186 ounces per ton gold), 150 feet with 0.071 ounces per ton gold (including 35 feet with 0.114 ounces per ton gold), and 145 feet with 0.04 ounces per ton gold (including 15 feet with 0.114 ounces per ton gold). The measured, indicated, and inferred resource at Rock Creek is presently 740,000 ounces of gold grading 0.081 ounces per ton gold using a cut-off grade of 0.03 ounces per ton. There is an additional inferred resource of 260,000 ounces of gold at a gold grade of 0.065 ounces per ton at the Saddle deposit 1.8 miles to the southeast. Metallurgical testing indicates that mineralization consists of native gold, pyrite, sulfosalt minerals, and arsenopyrite. Gold recoveries using cyanide averaged between 91 and 98 percent, with 37 to 86 percent (dependent on two main ore types) recovery possible using a gravity circuit at a 65 -mesh grind.

NovaGold Resources Inc. also announced a 2-millionounce placer gold resource on its Nome patented mining

Table 4. Reported exploration expenditures in Alaska by commodity, 1982-99

\begin{tabular}{|c|c|c|c|c|c|c|c|}
\hline & $\begin{array}{c}\text { Base } \\
\text { metals }\end{array}$ & Polymetallica & $\begin{array}{c}\text { Precious } \\
\text { metals }\end{array}$ & $\begin{array}{c}\text { Industrial } \\
\text { minerals }\end{array}$ & $\begin{array}{c}\text { Coal } \\
\text { and peat }\end{array}$ & Other & Total \\
\hline 1982 & $\$ 31,757,900$ & N/A & S $10,944,100$ & $\$ \quad \ldots$ & $\$ 2,900,000$ & 15,300 & S $45,617,300$ \\
\hline 1983 & $9,758,760$ & N/A & $20,897,555$ & $2,068,300$ & $1,338,454$ & 70,000 & $34,133,069$ \\
\hline 1984 & $4,720,596$ & N/A & $14,948,554$ & 270,000 & $2,065,000$ & 279,500 & $22,283,650$ \\
\hline 1985 & $2,397,600$ & N/A & $6,482,400$ & . & 270,000 & - & $9,150,000$ \\
\hline 1986 & $1,847,660$ & N/A & $6,107,084$ & 170,000 & 790,000 & -. & $8,914,744$ \\
\hline 1987 & $2,523,350$ & N/A & $11,743,711$ & 286,000 & $1,150,000$ & 31,000 & $15,734,061$ \\
\hline 1988 & $1,208,000$ & N/A & $41,370,600$ & 160,200 & $2,730,000$ & - & $45,468,800$ \\
\hline 1989 & $3,503,000$ & N/A & $43,205,300$ & 125,000 & 924,296 & 5,000 & $47,762,596$ \\
\hline 1990 & $5,282,200$ & $\mathrm{~N} / \mathrm{A}$ & $57,185,394$ & 370,000 & 321,000 & 97,000 & $63,255,594$ \\
\hline 1991 & $4,789,500$ & N/A & $34,422,039$ & 92,000 & 603,000 & 2,000 & $39,908,539$ \\
\hline 1992 & $1,116,000$ & $3,560,000$ & $25,083,000$ & 25,000 & 425,000 & - & $30,209,000$ \\
\hline 1993 & 910,000 & $5,676,743$ & $23,382,246$ & 163,500 & . & 125,000 & $30,257,489$ \\
\hline 1994 & 600,000 & $8,099,054$ & $18,815,560$ & 225,000 & $2,554,000$ & 810,000 & $31,103,614$ \\
\hline 1995 & $2,770,000$ & $10,550,000$ & $20,883,100$ & 100,000 & . & 3,000 & $34,306,100$ \\
\hline 1996 & $1,100,000$ & $11,983,364$ & $31,238,600$ & 400,000 & $\ldots$ & . & $44,721,964$ \\
\hline 1997 & $1,700,000$ & $22,347,000$ & $32,960,500$ & 80,000 & 720,000 & .. & $57,807,500$ \\
\hline 1998 & $1,000,000$ & $13,727,000$ & $42,441,000$ & 12,000 & 87,000 & - & $57,267,000$ \\
\hline 1999 & $3,869,000$ & $3,168,000$ & $44,891,000$ & 1,000 & . & 410,000 & $52,339,000$ \\
\hline TOTAL & $\$ 80,853,566$ & $\$ 79,111,161$ & $\$ 487,001,743$ & $\$ 4,548,000$ & $\$ 16,877,750$ & $\$ 1,847,800$ & $\$ 670,240,020$ \\
\hline
\end{tabular}

Figure 4. 1999 exploration expenditures by commodity.

Precious metals $\$ 44,891,000$

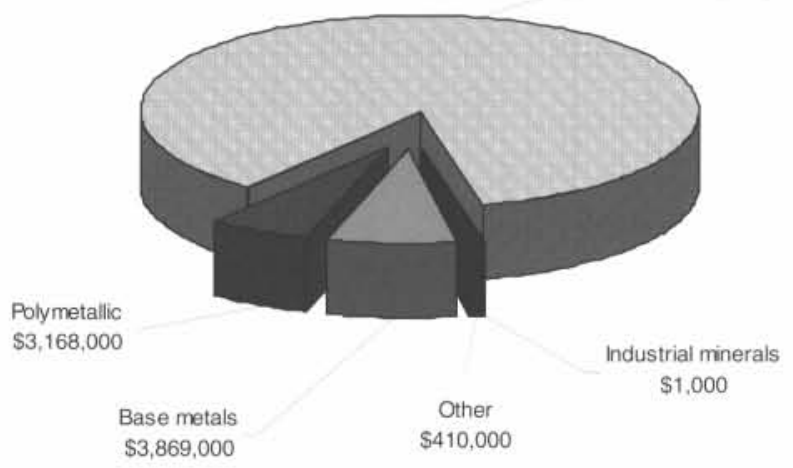


claims in marine beach and alluvial deposits. The resource was estimated using a modified polygonal method with data derived from 7,248 churn drill holes and over 70 years of historic production records. NovaGold believes that alternative stripping and mining methods, as well as improvements in fine gold recovery, could reduce overall mining costs and significantly enhance revenues.

Farther north at Mt. Distin (fig. 6), Consolidated Aston Resources Ltd. drilled 24 reverse-circulation holes for a total of 6,244 feet at the Fred Creek prospect and conducted other exploration work across the rest of the Mt. Distin property. Consolidated Aston is party to an exploration agreement and option to lease with Bering Straits Native Corp. (First Nation) and its subsidiary, Golden Glacier Inc. Drilling results are interpreted to reveal a strongly disseminated gold system that is tabular, crudely stratiform, and hosted by metasedimentary rocks. The mineralized zone is up to 285 feet thick, and can be traced along strike for at least 1,640 feet and down-dip 330 feet. Gold assay results are remarkably consistent, with many holes mineralized over their entire length. For example, hole MDRC-99-13 averaged 0.012 ounces per ton gold from collar to 308-foot depth, and hole MDRC-99-11 averaged 0.010 ounces per ton gold from collar to 308 -foot depth. Gold grades and thickness appeared to increase down-dip. Consolidated Aston believes that the pattern of mineralization is consistent with a leakage halo emanating from a down-dip mineralized source along the main structural trend. The company also conducted a phase 2 , four-hole, core-drilling program on the Fred Creek gold target. Core

\section{Northern Region}

1. Red Dog Mine/District-Cominco Alaska Inc.

2. Arctic deposit-Kennecott Minerals Co.

\section{Western Region}

3. Nome area-NovaGold Resources Inc./ Kennecott Exploration Co./Viceroy Resource Corp.

4. Mt. Distin-Consolidated Aston Resources Ltd., Altar Resources

5. Kaiyah-North Star Exploration Inc.

6. Indian River-North Star Exploration Inc.

\section{Eastern Interior Region}

7. Salcha River area-NovaGold Resources Inc., Camnor Resources Ltd., Oromin Exploration Ltd.

8. Fairbanks district

a. Fort Knox-Kinross Gold Corp.

b. Gil claims - Kinross Gold Corp./ Teryl Resource Corp.

c. General-Kinross Gold Corp.

9. Circle district - Copper Ridge Explorations Inc./Camnor Resources Ltd., Golden Phoenix Mineral Inc., Newmont Exploration Ltd.

10. Pogo

a. Pogo-Teck Corp./Sumitomo Metal Mining America Inc.

b. Pogo/Goodpaster area-Numerous companies

11. Bonnifield district - Grayd Resource Corp., Camnor Resources Ltd., Oromin Exploration Ltd.

12. Richardson district-Kennecott Exploration Co., Placer Dome Exploration Inc., Golden Phoenix Alaska Inc., Tri-Valley Corp.

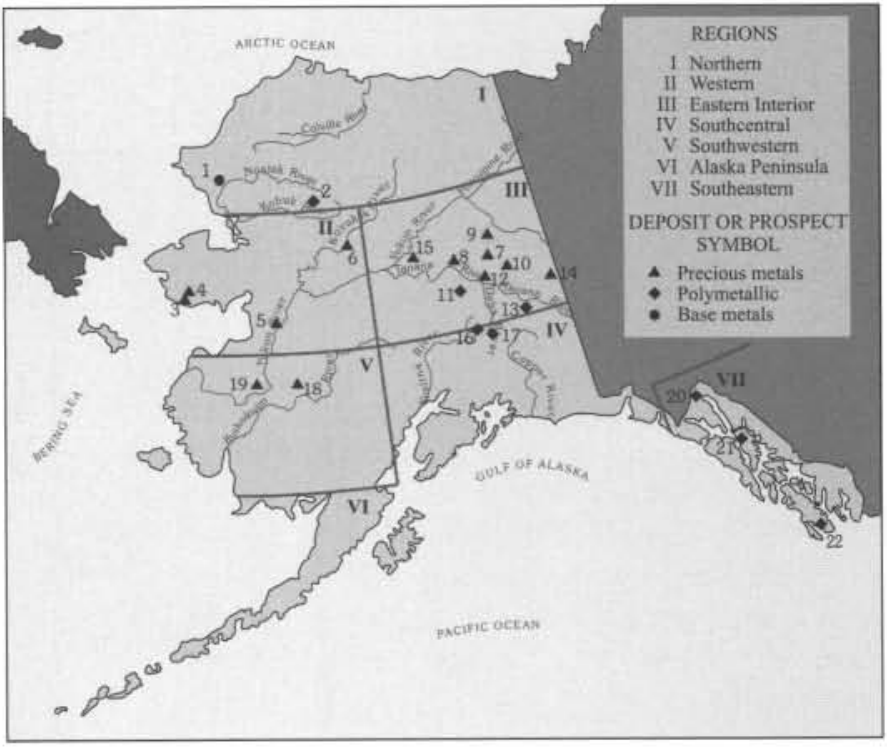

13. Delta Mineral Belt - Grayd Resource Corp.

14. Fortymile district (Napoleon project and general) - Kennecott Exploration Co.

15. Elephant Mountain - North Star Exploration Inc.

\section{Southcentral Region}

16. Caribou Dome (Denali Copper)-Atna Resources Ltd.

17. Nikolai Mafic-Ultramafic Belt-M.A.N. Resources Inc./Nevada Star Resource Corp., Fort Knox Gold Resources Inc./Inco Ltd.

\section{Southwestern Region}

18. Donlin Creek-Placer Dome Exploration Inc.

19. Stuyahok - Placer Dome Exploration Inc.

\section{Alaska Peninsula Region}

\section{Southeastern Region}

20. Palmer claims-Rubicon Minerals Corp.

21. Greens Creek-Kennecott Minerals Co./Hecla Mining Co.

22. Niblack-Abacus Minerals Inc./Teck Corp.

Figure 5. Selected exploration projects in Alaska, 1999. 
Table 5. Summary of claim activity, 1984-99

\begin{tabular}{|c|c|c|c|c|c|c|c|c|c|}
\hline \multirow[b]{2}{*}{ Year } & \multicolumn{3}{|c|}{ New Claims } & \multicolumn{3}{|c|}{ Active Claims } & \multicolumn{3}{|c|}{ Total Claims } \\
\hline & State & Federal & Subtotal & State & Federal & Subtotal & State & Federal & Total \\
\hline 1984 & 5,236 & 3,111 & 8,347 & na & na & 78,612 & na & na & 86,959 \\
\hline 1985 & 4,219 & 2,554 & 6,773 & na & na & 75,009 & na & na & 81,782 \\
\hline 1986 & 3,579 & 1,739 & 5,318 & na & na & 65,705 & na & na & 71,014 \\
\hline 1987 & 5,002 & 3,274 & 8,276 & na & na & 60,072 & na & na & 68,348 \\
\hline 1988 & 8,062 & 3,786 & 11,848 & na & na & 63,694 & na & na & 75,542 \\
\hline 1989 & 3,928 & 1,664 & 5,592 & na & na & 64,123 & na & na & 69,715 \\
\hline 1990 & 2,573 & 1,888 & 4,461 & 32,275 & 25,792 & 58,067 & 34,848 & 27,680 & 62,528 \\
\hline 1991 & 3,273 & 1,299 & 4,572 & 35,191 & 23,222 & 58,413 & 38,464 & 24,521 & 62,985 \\
\hline 1992 & 2,640 & 695 & 3,335 & 34,281 & 20,254 & 54,535 & 36,921 & 20,949 & 57,870 \\
\hline 1993 & 2,110 & 601 & 2,711 & 32,781 & 9,298 & 42,079 & 34,891 & 9,899 & 44,790 \\
\hline 1994 & 4,056 & 341 & 4,397 & 31,703 & 8,495 & 40,198 & 35,759 & 8,836 & 44,595 \\
\hline 1995 & 4,508 & 376 & 4,884 & 27,250 & 7,766 & 35,016 & 31,758 & 8,142 & 39,900 \\
\hline 1996 & 9,488 & 681 & 10,169 & 28,273 & 9,346 & 37,619 & 37,761 & 10,027 & 47,788 \\
\hline 1997 & 8,671 & 1,872 & 10,543 & 35,219 & 11,320 & 46,539 & 43,890 & 13,192 & 57,082 \\
\hline 1998 & 9,776 & 427 & 10,203 & 40,579 & 11,033 & 51,612 & 50,355 & 11,460 & 61,815 \\
\hline 1999 & $12,793^{a}$ & 308 & 13,101 & 44,583 & 10,176 & 54,759 & 57,376 & 10,484 & 67,860 \\
\hline
\end{tabular}

${ }^{a}$ An additional 1,892 prospecting sites, equivalent in area to 7,568 mining claims, were located in 1999, and 2,060 existing prospecting sites ( 8,240 claim equivalents) were extended for a second year.

Federal claims $=20$ acres, State claims $=40$ acres, State prospecting sites $=160$ acres.

na - Specific data regarding State and Federal claims not available.

Information post 1990 provided by John Cacy (Land Records Information Section, DNR) and Evvie Garis (USBLM). Table has been reorganized to conform with computer records available after 1990. Data prior to 1990 from Special Reports 40 and 44.

drilling totaled 2,267 feet with best results of 87 feet of 0.014 ounces per ton gold in hole MDC99-10 and 421 feet grading 0.10 ounces per ton gold in hole MDC99-11. To date, the Fred Creek prospect has a preliminary, estimated gold resource of 74,000 ounces at an average grade of 0.016 ounces per ton gold with a cut-off grade of 0.01 ounces per ton gold. The estimate was prepared using a cross-sectional method.

Altar Resources explored its Divide gold prospects and several base-metal showings. Pan sampling on the Divide property continued definition of a placer gold resource. During 1999 Altar Resources hand excavated and bulk sampled five pits that extended mineralized bedrock to a total distance of 2,300 feet with an average gold content of 0.02 ounces per ton. Geologic mapping at a 1:1,000 scale by Dr. Wyatt Gilbert on the Bulk Gold prospect reveals a spatial relationship between feldspathic orthogneiss (metagranite) and gold anomalies. Three shallow Winkie AX core holes were drilled at the Bulk Gold prospect for a total of 260 feet. Drillhole 99BGDH3 confirmed the presence of anomalous gold up to

Figure 6. Core drilling by TJ Enterprises for gold mineralization on the Fred Creek prospect at Mt. Distin. Phase 2 of Consolidated Aston Resources Ltd.'s exploration drilling program. Photo provided by Tom Sparks, Bering Straits Native Corp.
Table 6. Red Dog ore reserves ${ }^{a}$

\begin{tabular}{lcccc}
\hline & $\begin{array}{c}\text { Tons } \\
\text { (millions) }\end{array}$ & $\begin{array}{c}\text { Zinc } \\
(\mathbf{w t} \%)\end{array}$ & $\begin{array}{c}\text { Lead } \\
(\mathbf{w t} \%)\end{array}$ & $\begin{array}{c}\text { Silver } \\
(\mathbf{o z} / \text { ton) }\end{array}$ \\
Main (Proven \& Probable) & 51.2 & 19.0 & 5.2 & 2.95 \\
Aqqaluk (Possible) & 80.4 & 13.6 & 3.7 & 1.90 \\
Hilltop (Indicated) & 10.6 & 17.8 & 5.5 & 3.41 \\
Paalaaq (Inferred) & 14.3 & 15.0 & 4.0 & 2.63 \\
Total/Average & $\mathbf{1 5 6 . 5}$ & $\mathbf{1 5 . 8}$ & $\mathbf{4 . 3}$ & $\mathbf{2 . 4 2}$ \\
\hline
\end{tabular}

aAs of December 31, 1999 from Cominco 1999 Annual Report.

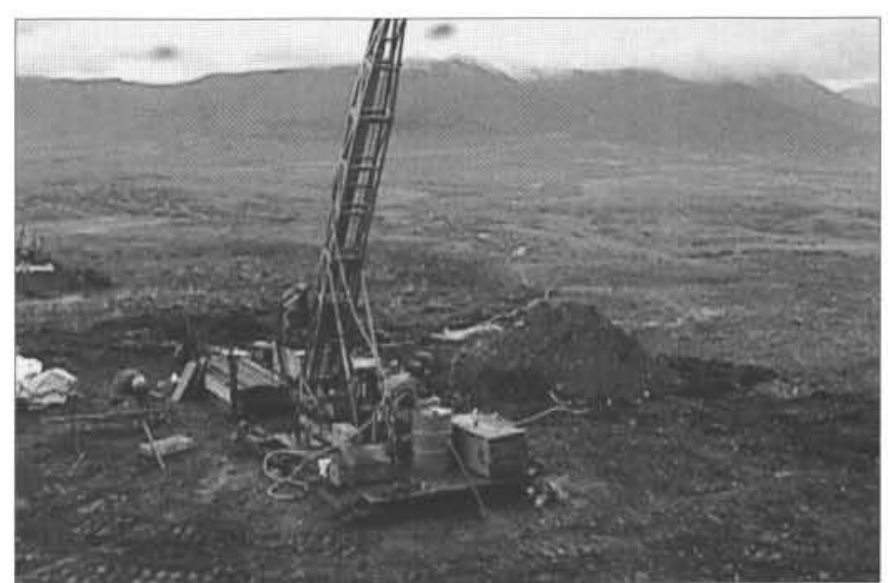


0.0375 ounces per ton, with 9,310 parts per million arsenic, and 7,170 parts per million antimony in a five-foot intercept, and an average of 0.02 ounces per ton gold over the entire 55-foot depth. Altar subsequently optioned the Bulk Gold property to Consolidated Aston Resources Ltd.

Altar also conducted exploration on the Midas Well property on the east side of the Mount Distin property. A coincident gold, arsenic, and antimony anomaly was identified by 80 mobile metal ion soil geochemical samples and 12 conventional soil samples. The geochemical anomaly is coincident with a northeast-trending magnetic anomaly on the DGGS airborne magnetic map of the Nome D-2 Quadrangle. Noranda Mining and Exploration Inc. conducted several days of sampling on Altar's Think Zinc and Metal Heaven base-metal properties.

Viceroy Alaska, a division of Viceroy Resources Corp., conducted exploration at the Illinois Creek Mine near Galena as part of its evaluation of the deposit.

North Star Exploration Inc. discovered a new goldsilver epithermal prospect approximately 80 miles southwest of Galena on the west side of the Yukon River. North Star's Kaiyah prospect consists of 80 state claims and 17 state prospecting sites totaling 5,920 acres. Host rocks include sandstone, shale, and conglomerate of the Koyukuk terrane adjacent to the Poison Creek caldera. Volcanic rocks include intermediate to felsic ash flow tuffs, massive basaltic andesite, and a small area of siliceous sinter. Anomalous gold and silver values occur in outcropping silicified sedimentary units cut by radial faults immediately east of the caldera rim. Structural analysis from fused Landsat and total field magnetic data suggests that the caldera system may extend over 12 miles in diameter.

North Star collected 236 rock samples at Kaiyah, and 46 samples contained over 0.003 ounces per ton gold. Gold values ranged up to 0.30 ounces per ton and silver values ranged up to 13.6 ounces per ton. Arsenic and bismuth values are elevated with higher precious-metal values, and mercury occurs in the low parts per million range. Silica veining was mapped in a structurally bounded zone that is 9,000 feet long and averages 4,000 feet wide. The upper part of the mineralized system consists of vuggy silica with open spaces lined by comb quartz; 300-400 feet lower in the system, silicification is characterized by stockwork veinlets and quartz flooding as a dense matrix. Altered areas contain pervasive alunite, jarosite, and sericite. Some steeply dipping veins are over 100 feet thick.

North Star also explored on Doyon Ltd.'s land near the village of Hughes on the east bank of the Koyukuk River. Fieldwork on the Indian River property identified an altered granodiorite body. The granodiorite exposure coincides with magnetic and resistivity geophysical anomalies. North Star believes that the granodiorite may be the source of the Indian River placer gold deposits.
North Star also worked on several properties within Doyon's Block 20 along the Yukon River. The Windy Creek zinc prospect is on the northwest side of the Yukon River near Senatis Mountain, approximately 25 miles north-northeast of Tanana. During 1999, North Star extended an 8,000 -foot zinc soil anomaly outlined by WGM in 1977 to almost five miles in length, with a maximum width of 700 feet. Two new areas of bedrock zinc mineralization were discovered: a mineralized carbonate breccia that assayed 3.6 percent zinc and 0.2 percent lead, and a gossanous area with up to 3.18 percent zinc. Float samples of massive pyrite with sphalerite are common in the area. The target model is a carbonate replacement deposit, possibly a skarn, related to a nearby Cretaceous granite body.

\section{EASTERN INTERIOR REGION}

The biggest news from the Fairbanks district was the announcement that Kinross Gold Corp. completed acquisition of Newmont Exploration's rights in the 1.3-million-ounce True North gold project. Kinross paid $\$ 28$ million to buy back 100 percent interest in the deposit. The property had been part of a joint venture between Newmont and La Teko Resources; the latter company was recently acquired by Kinross. Newmont had expended about $\$ 19$ million at the True North property since taking over project management in 1995. Kinross immediately began evaluating the deposit with respect to trucking ore to the Fort Knox mill. True North ore grades are nearly three times that of Fort Knox ore. Production from True North is projected to increase annual production through the Fort Knox mill by about 100,000 ounces of gold. Kinross also acquired the adjacent Whiskey Gulch property from Silverado Gold Mines Ltd. in exchange for a net smelter royalty based on gold price at production.

Kinross Gold and 20 percent joint venture partner Teryl Resources announced drilling results for their Main Gil and North Gil prospects; indicated and inferred resources stand at 10.7 million tons grading 0.040 ounces per ton (433,000 ounces of gold). Drilling consisted of five diamond core holes $(3,911$ feet $)$ and nine reverse-circulation holes (4,038 feet). Highlights of drilling at Gil North include 65 feet grading 0.041 ounces per ton and 75 feet grading 0.043 ounces per ton. Significant intercepts at the Main Gil prospect included 40 feet grading 0.068 ounces per ton and 120 feet grading 0.036 ounces per ton. Geophysical data interpretation indicated previously unknown geologic structures with east-west and northeast trends, and exploration targets on the east side of Slippery Creek and in All Gold Creek. Soil sampling outlined new areas with anomalous gold values in the North Gil area and in the eastern portion of the Gil Venture claim block. Kinross and Teryl also conducted some exploration on the West Ridge property abutting the southern boundary of the True North property. Kinross conducted a limited reverse- 
circulation drilling program on the Amanitaville property south of Fort Knox Mine, with best drill intercepts of 50 feet of 0.08 ounces per ton of gold, 50 feet of 0.29 ounces per ton of gold, and 90 feet of 0.04 ounces per ton of gold.

The Goodpaster mining district to the east of Fairbanks was the locus of most exploration activity during 1999. The Pogo deposit, a 5.2-million-ounce gold prospect being evaluated by Teck Corp. and partner Sumitomo Metal Mining, was the largest exploration project in Alaska during 1999. An underground exploration permit from state and federal agencies was received in March and development work immediately began on the adit (fig. 7). Plans are to dig approximately 5,200 feet into the hillside (Pogo Ridge) hosting the Liese 1 zone orebody. The adit will intersect the Liese 1 zone (fig. 8), the uppermost of three known mineralized zones on the project. Access to the Liese 1 zone will allow collection of a bulk sample for metallurgical testing purposes, obtain geotechnical data, and test continuity of ore bodies. Drilling from the Liese 1 level will attempt to better define the deep Liese 3 zone previously intersected in two holes drilled from the surface. Teck had excavated approximately 3,000 feet of the adit, drilled a shaft pilot hole to 2,500 feet and completed a prefeasibility study by the end of 1999 (fig. 9).

Teck also conducted a $\$ 2.6$ million surface exploration program on the 1,200-claim Pogo property. Sixty-four diamond core holes, totaling 50,000 feet, were drilled in 1999, including 32,000 feet of infill definition drilling around the Liese zone, 7,000 feet of geotechnical drilling, and 4,000 feet of exploration drilling. As a result of the summer surface infill-drilling program, the geologic (indicated and inferred) resource for the Pogo project has been upgraded seven percent to 10.7 million tons at a grade of 0.524 ounces per ton, for a total of 5.6 million contained ounces.

Teck announced a new orebody, the "North Zone," approximately 800 feet northwest of the Liese zone. The North Zone, consisting of two north-trending, east-dipping

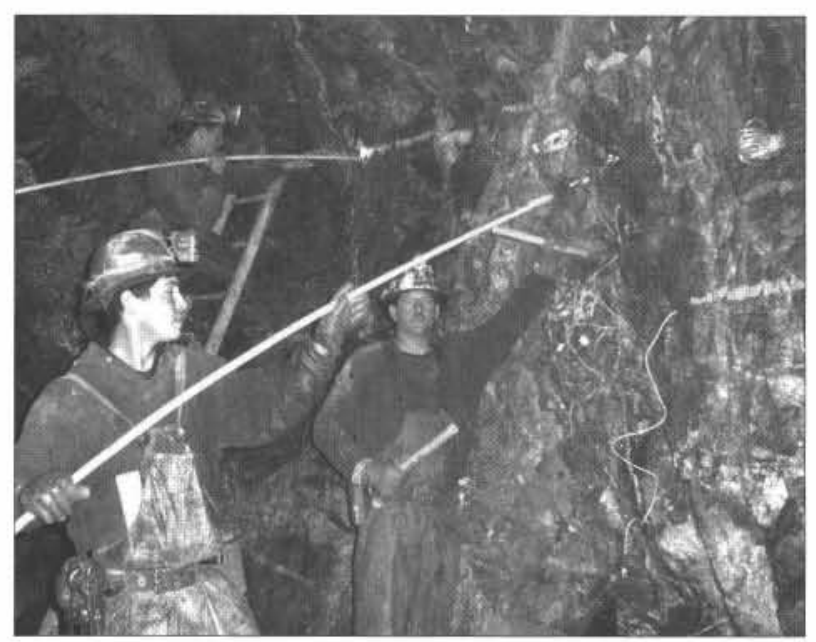

quartz veins, was discovered on surface and intersected in the planned shaft pilot hole. Other exploration drill footage targeted the southeast extension of the main Liese zone mineralization and the Sonora Creek prospect 5 miles southeast of the main deposit area. The Sonora Creek soil grid reportedly has higher gold anomalies than the original Liese soil anomaly.

Numerous companies staked land around the Pogo deposit in 1998, and though depressed gold prices hindered financing necessary to complete exploration programs, several 1999 programs identified interesting gold targets in the Goodpaster region. Avalon Development Corp. managed joint exploration programs for nine different companies in the Goodpaster district. Their work revealed that in some places in the Goodpaster area, 10 parts per billion gold might be a significant value to pursue with further geochemical sampling.

Western Keltic Mines Inc. struck a deal with Barrick Gold Corp. on five of Western Keltic's and Rimfire Minerals Corp.'s properties (California, Surf, Big Bend, Boogie, and Central Creek) in the Goodpaster district. Barrick has the option of earning a 51 percent interest in any of the five properties. Exploration in 1999 consisted of geologic mapping, prospecting, and geochemical sampling of soils and rocks on the Boundary prospect along the northern border of the California and Surf properties, on the southeastern part of the Surf property, and in the Beverly Creek area of the California property. Western Keltic collected over 3,400 soil, 375 rock, and 285 streamsediment samples for geochemical analysis. This work resulted in the discovery of large multi-element soil geochemical anomalies and zones of gold-bearing quartzveined boulders, with values of up to 0.72 ounces per ton of gold. The Boundary prospect has a 2,300-foot-long soil anomaly with gold values ranging from 10 to 40 parts per billion associated with anomalous arsenic, bismuth, tellurium, antimony, and tungsten. The southeast Surf soil anomaly extends over 2.7 miles in a northwest-southeast direction and contains gold values up to 70 parts per billion with associated anomalous arsenic, bismuth, antimony, and tungsten. The Beverly Creek area has anomalous gold values in stream-sediment samples with an undefined extent.

Hyder Gold Inc. optioned five properties from Rimfire Minerals Corp. in the Pogo area and completed a Phase I program of contour soil sampling, stream-sediment sampling, prospecting, and reconnaissance geological mapping. Coincident gold (up to 0.009 ounces per ton), arsenic, bismuth, and antimony anomalies outlined a 1.8 -mile by 0.9 -mile area on the Eagle property and quartz-veined float on the Bou property. A Phase II program of systematic grid-based

Figure 7. Day shift working on the face in the Pogo decline. Photo provided by Teck Resources Inc. 
soil sampling, detailed geological mapping, and further prospecting on these properties identified gold mineralization (up to 0.17 ounces per ton of gold) related to quartz veinlets cutting Cretaceous granite. Elsewhere, Blackstone Resources terminated its option on Rimfire's Falcon property due to lack of financing.

Copper Ridge Explorations Inc. acquired five properties from KGE Management Ltd., which acquired the properties from Kinross Gold immediately after the closing of the Kinross-La Teko Resources merger. Alaskan properties include Discovery Gulch in the Circle mining district and Ogopogo in the Goodpaster mining district. Discovery Gulch had been under option to Camnor Resources Ltd. but Camnor terminated its option after a five-hole ( 1,520 foot) reverse-circulation drilling program in 1999 with the best intercept of 20 feet of 0.035 ounces per ton of gold in sericite-chlorite-carbonate-altered granodiorite with quartz veins containing up to 5 percent pyrite and 1 percent arsenopyrite. Copper Ridge conducted a soil auger sampling to test two significant gold-in-soil anomalies. Copper Ridge Explorations also acquired the right to earn 100 percent of the McKenzie claim block in the Circle district and conducted a reconnaissance sampling program.

Copper Ridge's Ogopogo project 1999 exploration program involved collecting 121 stream-sediment samples.
Gold values in stream sediments ranged up to 0.006 ounces per ton and coarse fraction samples returned gold values up to 0.047 ounces per ton. Other anomalous elements include arsenic, antimony, and tungsten. A subsequent soil geochemical survey collected 325 samples and identified three targets with gold values up to 0.008 ounces per ton and anomalous arsenic, bismuth, lead, antimony, and tellurium. Kinross Gold acquired the Northern Cross prospect from Copper Ridge Explorations. The Northern Cross prospect is 2 miles north of the Pogo deposit and is host to bismuth and tungsten pan concentrate anomalies from streams underlain by rocks similar to those which host the Pogo deposit.

Almaden Resources Corp. and partner Williams Creek Exploration Ltd. conducted stream-sediment, coarse-fraction sampling and prospecting programs on the Sonora property. Five drainages contained samples with values up to 40 parts per billion gold, with a background of less than 5 parts per billion gold.

Camnor Resources Ltd. and Oromin Exploration Ltd. conducted soil sampling, mapping, and prospecting on the 6-square-mile South Salcha project 25 miles northwest of the Pogo property. The work program consisted of 27 linemiles of soil sampling, geologic mapping, and rock sampling. Three linear, east-west-trending soil anomalies

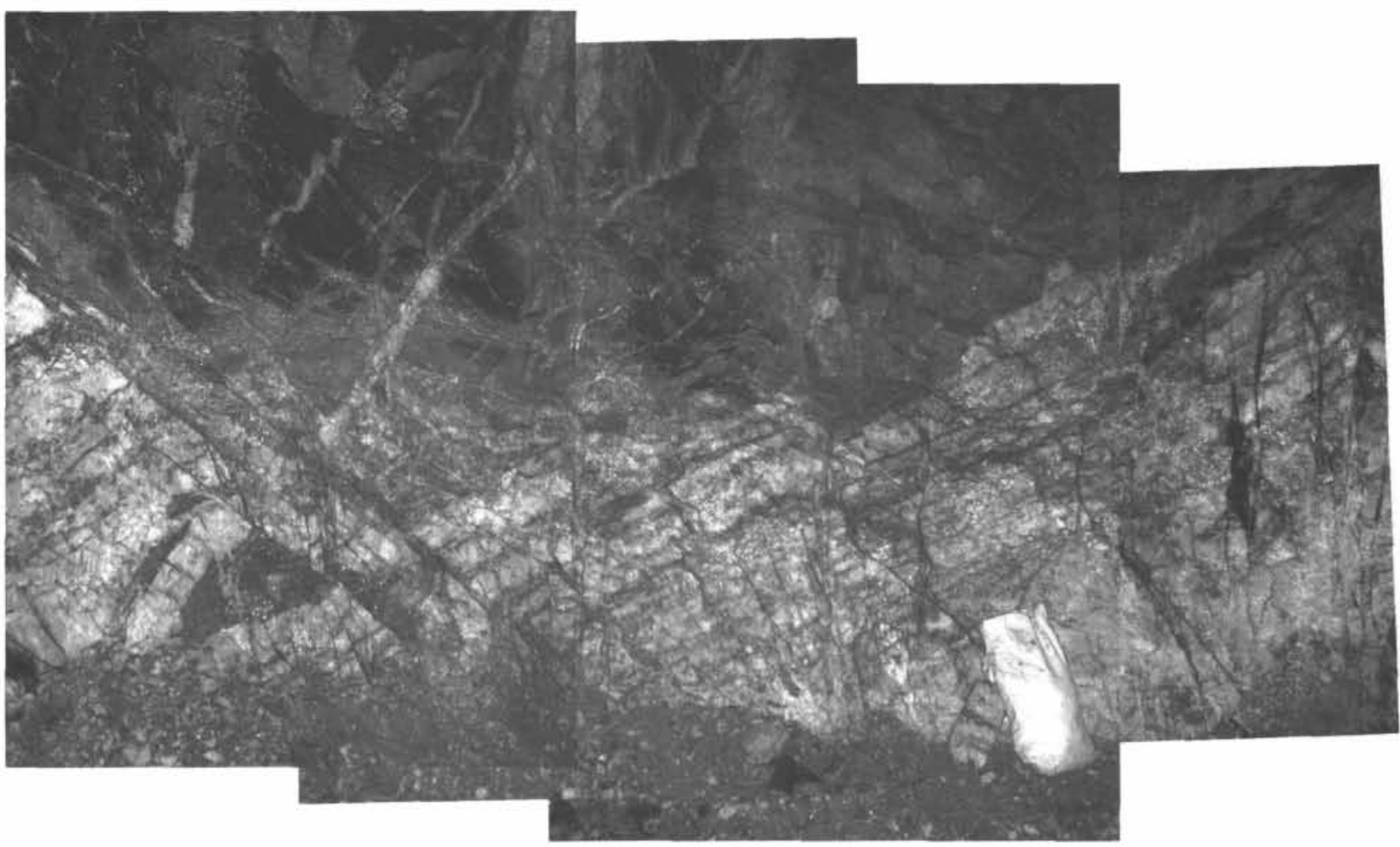

Figure 8. Composite photo of the Liese 11/2 vein, a newly discovered vein exposed in the Pogo decline that occurs between the Liese 1 and Liese 2 veins. Black bands in white quartz vein are mostly fine-grained sulfide minerals and some wallrock. Sample bag size is 11 inches by 17 inches. Photo provided by Teck Resources Inc. 
defined by greater than 20 parts per billion gold occur at or near contacts between intrusive and gneissic rocks. The anomalies are 650 feet wide and vary from 2,600 to 4,600 feet long, with soil sample assays up to 140 parts per billion gold.

Valerie Gold Resources Ltd. entered into two option agreements to acquire an interest in the Octo property northwest of Pogo. Geologic mapping and geochemical surveys were completed, after which Valerie dropped its option.

Troymin Resources Ltd. collected over 400 streamsediment and coarse-mineral-fraction samples from several creeks on five claim blocks southeast of Pogo. Gold values up to 0.015 ounces per ton, associated with anomalous bismuth, arsenic, molybdenum, and copper, were found at several areas.

NovaGold Resources Inc. identified three half-milescale drill targets on its 30-square-mile Caribou Creek project 25 miles northwest of the Pogo property. Each area contains highly anomalous gold, arsenic, antimony, and bismuth in surface rock chip and soil geochemical samples. Follow-up sampling on the No Grub Zone identified anomalous gold in soil values up to 0.03 ounces per ton of gold and rock chip samples with up to 0.11 ounces per ton of gold. Rock chip sampling in the newly identified Headwaters Zone returned values of up to 0.06 ounces per ton of gold. The northeast-trending Caribou Zone had values in rock chip samples up to 0.07 ounces per ton of gold. A detailed aeromagnetic and radiometric geophysical survey was flown over the Caribou Creek project area during the month of August. The 1999 Caribou Creek project exploration program was funded by Kennecott Exploration Co. as part of a joint-venture agreement with NovaGold, but Kennecott elected to discontinue funding after the 1999 season.

Ventures Resource Corp. and equity partner Teck Corp. completed 8,000 feet of diamond drilling in ten holes on the Carrie Creek portion of the Veta property in the
Goodpaster district. Extensive soil sampling augmented the drilling program at the Carrie Creek prospect. The best drill intercept was 23 feet of 0.03 ounces per ton of gold. The final two 1999 drill holes were relocated 2 miles south to test the newly discovered Serpentine zone. Drill core from the Serpentine zone contained altered, fractured, and veined rock. Results from the North Veta Area program (comprising the north-central segment of the Veta property) defined clusters of stream-sediment gold anomalies, with values ranging up to 0.029 ounces per ton gold, and highest panned concentrate values in the ounces per ton range. Sumitomo had a major program including drilling at the nearby Black Mountain prospect.

Ventures Resources also signed an exploration option agreement with Kennecott Exploration Co. on Ventures' 950-square-mile Champion property in the Fortymile mining district. Kennecott will focus its efforts on exploration for intrusive-related gold deposits. The agreement provided Kennecott the exclusive option to secure a joint venture with Ventures prior to October 31,1999.

International Bravo Resource Corp. made a joint-venture agreement with Zeus Exploration, an affiliate of North Star Exploration Inc., for the East Divide, West Pogo, and Central gold prospects near Teck's Pogo property and Venture Resources' Veta property. Rock samples from an east-west trending, 1,000 foot by 4,000 foot quartz stockwork and sheeted zone hosted by intrusive rocks at the East Divide property assayed up to 0.19 ounces per ton gold, 1.1 percent copper and 3,860 parts per million bismuth. Visible sulfides within the quartz veins include pyrite, chalcopyrite, molybdenite, and bismuthinite. The West Pogo property has a wolframite-bismuthinitescheelite vein prospect hosted by igneous rock and values up to 0.029 ounces per ton gold and 2,190 parts per million bismuth have been reported from samples collected there. Three other tungsten- and bismuth-bearing quartz

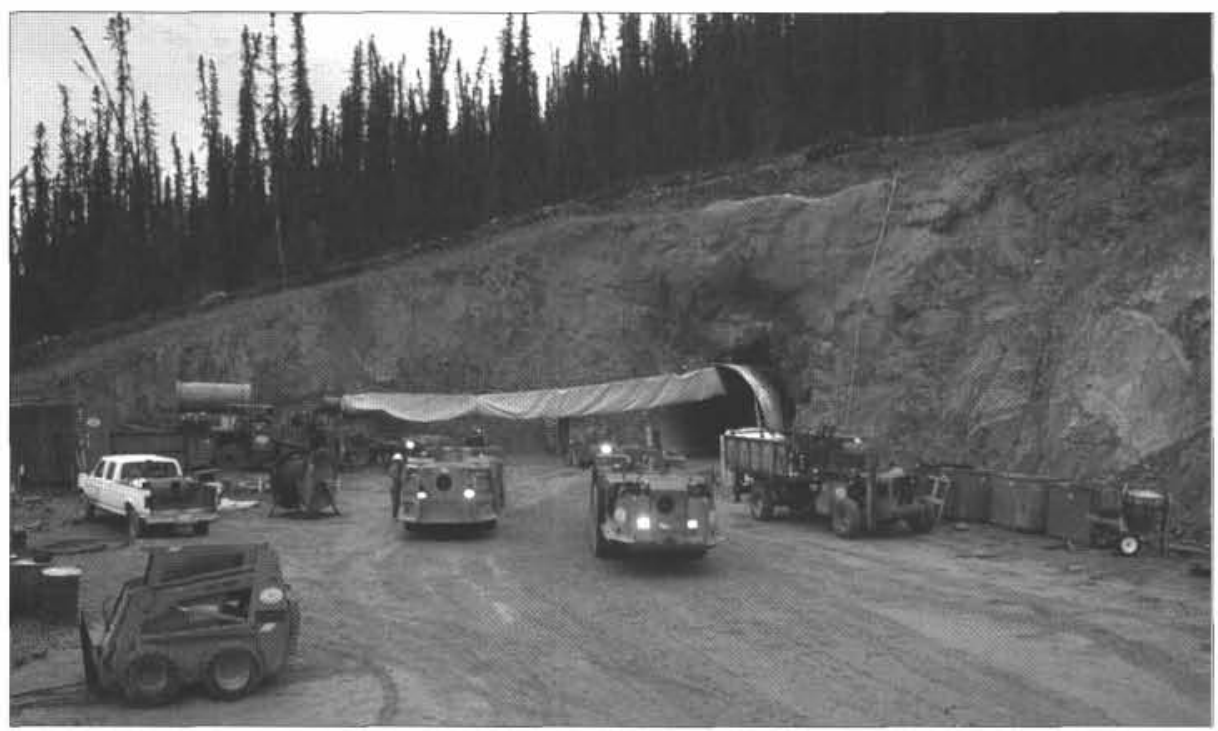

Figure 9. Early construction of Pogo decline and portal facilities. Photo provided by Teck Resources Inc. 
veins occur near the schist-pluton contact on the West Pogo property. International Bravo also signed a letter of intent to acquire 51 percent interest in three other North Star Exploration properties known as the Highway Village Block properties. Bravo acquired an option from Hunter Exploration Group in ten property blocks in the Pogo and Fairbanks areas.

Blue Desert Mining Inc. conducted initial exploration programs on the Gobi-Portal and Mojave properties immediately southeast of the Pogo property. These properties cover 27,000 acres. Two areas with anomalous gold, tellurium, antimony, and bismuth values from stream-sediment samples were discovered and named the Sevenmile Creek and Portal areas. Blue Desert also worked on the Sahara property to the east of Pogo and collected a stream-sediment sample with 0.031 ounces per ton gold along with anomalous tellurium, antimony, and arsenic values. Blue Desert signed an agreement with AngloGold (U.S.A.) Inc. on the three properties in early 2000 .

Fairfield Minerals Ltd. conducted a field program of geochemical sampling and prospecting on the Rock Creek and Shawnee properties northeast of Pogo. Streamsediment and soil samples indicated weak but anomalous gold values ranging from 10 to 40 parts per billion in several areas. Other companies conducting initial exploration programs in the Goodpaster mining district include Snowfield Resources Ltd. on the Boulder Creek property, Camflo Resources Ltd. on the Gobi property, Newmont Alaska Ltd. on a property north of Pogo, and Achieva Development Corp. on the Shaw Creek property.

Golden Phoenix Alaska (Minerals Inc.) joined the flurry of claim staking in the emerging Uncle Sam area of the Richardson district southwest of the Pogo deposit. Other companies in the new staking fray were WGM Inc./ Sumitomo, On-Line Exploration, and Anglo Alaska Gold.

Newmont Alaska Ltd. optioned the Gold Dust property in the Circle mining district from Great Quest Metals Ltd. Previous drilling on the property intercepted one zone containing 0.027 ounces per ton of gold over a width of 180 feet. Newmont confirmed previous work on the Alpine Zone and identified three new areas of anomalous gold values in soil samples. Newmont controls approximately 60 square miles of properties in the district.

Tri-Valley Corp. reached final agreement with Placer Dome Exploration Inc. on the 36-square-mile Buck and Buckeye portions of Tri-Valley's 51-square-mile Richardson project in the Richardson mining district. Placer Dome conducted a geologic mapping and geochemical survey using a broad-base soil auger sample grid. Several coincident gold, bismuth, tellurium, and tungsten anomalies were identified and three diamond drill holes were drilled in the area of one of the anomalies. Placer Dome notified Tri-Valley that it would proceed with the second year of exploration in 2000. Tri-Valley continued explora- tion on the retained 14.5-square-mile portion of the claim block that includes the Democrat Dike lode prospect and on a promising high-grade placer prospect. Previous bulk sampling at the Democrat prospect yielded over 3,000 rough ounces of lode gold from 30,000 tons of partially crushed ore. Three Russian geologists from TsNIGRI continued evaluation of this mineralized dike system and identified a new gold-bearing zone. Ten square miles of 160 -acre prospecting sites were staked to cover the trend. In the same area, Kennecott Exploration optioned ground from Golden Phoenix Minerals Inc. and conducted district-wide exploration.

Grayd Resource Corp. identified a significant goldbearing zone on the Rumble Creek property west of Tok in the Delta mineral belt (fig. 10). Sampling of the White Gold trend outlined gold-bearing silicification zones up to 55 feet wide along the 5-mile trend. Gold values up to 1.79 ounces per ton, along with anomalous arsenic and antimony values, are associated with northeast-trending silicified structures with quartz-sericite and carbonate alteration envelopes and pyrite, arsenopyrite, and stibnite mineralization. Grayd also worked on the Dan-IC gold property in the Delta district. Grayd signed agreements late in the year to acquire 100 percent control of the Delta and Rumble Creek properties.

Grayd optioned its Dry Creek prospect in the Bonnifield district south of Delta to Atna Resources Ltd. in June 1999. Atna funded a 14-hole, 10,260-foot diamond drill program. Twelve drill holes tested the DC North base metal, massive-sulfide mineralized horizon over a 13,500-foot strike length and two holes tested a large alteration zone underlying the DC North horizon. No exploration was carried

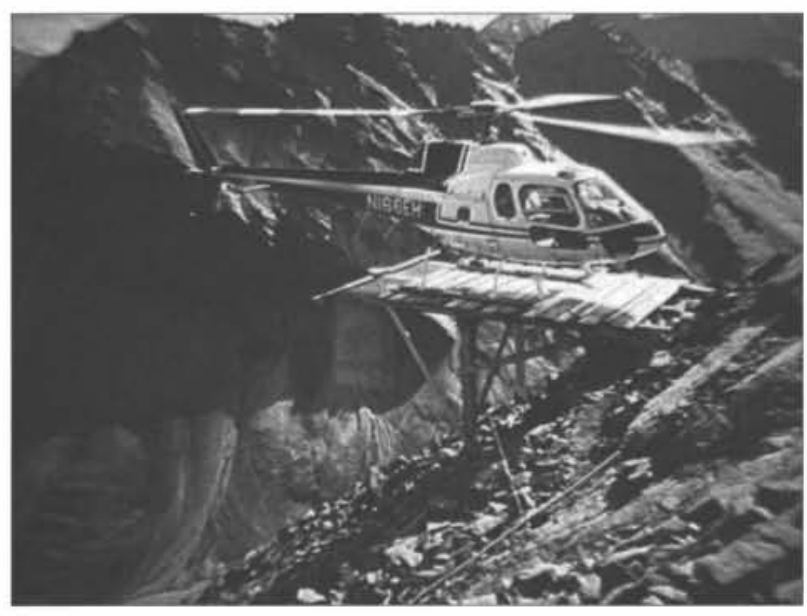

Figure 10. Era helicopter landing at American Copper \& Nickel Co. (ACNC) drill site on south face of Tiger Mountain, Delta mineral belt. Meine Huser of Alaska Dreams Inc. (ADI) constructed helipad. Photo by Sam Dashevsky. 
out in the WTF area or on the Anderson Mountain property. Drilling intersected an intense quartz-sericite-pyrite alteration zone 2,500 feet to the west of the Fosters zone along the DC North horizon. Drill hole DC99-65 intersected 5.5 feet of massive sulfide averaging 7.9 percent zinc, 4.0 percent lead, 3.74 ounces per ton silver, and 0.014 ounces per ton of gold. DC99-63, drilled in the Fosters zone down-dip of DC98-60, averaged 4.3 percent zinc, 2.0 percent lead, 2.07 ounces per ton silver and 0.014 ounces per ton of gold over 160 feet. DC99-64 intersected 10.5 feet grading 5.3 percent zinc, 1.8 percent lead, and 0.82 ounces per ton silver within a pyritic host rock with a true width of 100 feet. DC99-66 in the Discovery zone intersected 56 feet of 2.07 percent zinc, 0.77 percent lead, and 0.13 ounces per ton silver. Drilling results did not meet Atna's objective of defining a large deposit and Atna terminated its option with Grayd.

The 1999 exploration program at the Cirque property in the Bonnifield district by Camnor Resources Ltd. and Oromin Exploration Ltd. consisted of geologic mapping and reconnaissance diamond drilling. Four drill holes were completed on the Discovery zone and two holes were drilled on the Dol zone, for a total of 1,020 feet. The best volcanogenic-massive-sulfide mineralization intercepts were from hole 99-1 drilled on the Discovery zone, with 18 feet at 64 feet depth grading 0.08 ounces per ton of gold, 2.17 ounces per ton silver, and 11.55 percent combined zinc-lead-copper, and a second lens with a 6.6-foot width at 93.8 feet depth grading 0.027 ounces per ton of gold, 1.39 ounces per ton silver, and 11.49 percent combined zinc-lead-copper. The Discovery zone is interpreted to be a west-striking, moderately north-dipping zone plunging shallowly to the east. The Discovery zone has been traced for 2,300 feet along strike to the west and remains open along strike and down-dip to the north. Mineralization at the Dol zone is interpreted to represent mineralization distal to a vent source localized in dolomite.

North Star Exploration Inc. worked on the 89-millionyear-old Elephant Mountain pluton near Rampart. Placer Dome Exploration Inc. discovered visible gold in altered granite outcrops at Elephant Mountain in 1991 and drilled several core holes containing anomalous gold in silicified, highly fractured granite. Placer Dome's soil sampling program outlined an open-ended 6,000 -foot by 1,500-foot zone of anomalous gold and arsenic. Soil sampling by North Star in 1999 indicates that the anomalous zone continues for at least another 2,000 feet along the northeast-striking zone. Some of the soil anomalies coincide with high resistivity linears that are inferred to be surface expressions of fault/fracture zones in the pluton. North Star also explored the Step Mountain and nearby VABM Casca and Three Castle Mountain areas for Mississippi Valley type leadzinc mineralization.
Cambior Exploration worked in the Livengood area. Cusac Gold Mines Ltd. signed an agreement to acquire an 80 percent working interest in the Moran Dome project, a 200-claim block covering 8,000 acres in the Melozitna mining district about 110 miles northwest of Fairbanks. The area contains historic placer mining locations, and streamsediment sampling of local creeks outlines five anomalous regions with samples in excess of 0.30 ounces per ton gold.

Pacific Bay Minerals Ltd. acquired the TRIB property in the Ladue River area near the Canadian border. Limited lode exploration has identified anomalous gold values in quartzite and quartz breccias. Nearby, Achieva Development Corp. optioned a 50 percent interest in the Ladue claims to Luminex Ventures Inc. late in the year.

The State's Division of Geological \& Geophysical Surveys awarded an airborne geophysical contract to Stevens Exploration Management Corp. and subcontractor, Geoterrex-Dighem, for about 950 square miles of the Salcha and Goodpaster mining districts. For the first time, the DGGS survey included radiometric data, which have proven useful for delineating rock types and alteration. Survey results will be released in early February 2000. DGGS conducted geological mapping and geochemical sampling in the area around Chicken as part of groundtruthing airborne geophysical surveys released earlier in the year. This work is part of a planned three-year study of the Fortymile mining district.

\section{SOUTHCENTRAL REGION}

Atna Resources Ltd. concluded a deal in early 1999 to earn 100 percent interest in the Caribou Dome Property. The Caribou Dome Property (previously known as the Denali Copper or Pass Creek prospect) is in southcentral Alaska, approximately 160 miles northeast of the city of Anchorage. The project site is several miles east of the former Valdez Creek placer mine. The Caribou Dome Property consists of 20 federal unpatented lode mining claims, ten millsite claims and 20 State of Alaska mining claims totaling approximately 1,258 acres. Previous work delineated 550,400 tons of mineralized material with an average grade of 5.84 percent copper within three of the nine known sulfide lenses. Atna conducted geochemical, geological, and geophysical surveys followed by a three-hole 2,442 foot diamond drill program to expand the potential size of the deposit. Geophysical surveys included induced polarization (IP), mise-a-la-masse, and ground magnetics. The IP survey defined two significant anomalies beyond previously known mineralization; a strong 700 -foot-long chargeability high trending westward from the No. 2 Zone, and a second 600 -foot-long anomaly south of and parallel to the eastern mineralized trend. Hand trenching extended the main mineralized trend 500 feet farther to the east. Chip samples from the new trench exposures assayed up to 6.7 percent copper over 2 feet. 
Highlights of the 1999 Caribou Dome core drilling program are 5 feet of 5.9 percent copper from 1,059 to 1,064 feet (CD99-101) and one foot of 6.3 percent copper from 309 to 310 feet (CD99-102). Both drill intercepts were hosted in finely bedded pyrite and chalcopyrite within a calcareous argillite sequence. Results from the 1999 surface exploration and diamond drill program indicate good potential exists for expanding the areas of known mineralization of this prospective but complex property.

Usibelli Coal Mine Inc. was granted exploration permits for the Wishbone Hill property. The most coal that Usibelli can haul out of the area under the two-year exploration permit is 250 tons. Exploration trenches can be up to 30 feet wide and 250 feet long. Usibelli's permit allows 50 drill holes.

Shear Minerals Ltd. entered into a letter of intent with Shulin Lake Mining Inc. that allows Shear the right to earn a 50 percent interest in the Shulin Lake property. The property contains a large 2-3 mile diameter circular positive magnetic anomaly that is interpreted to be a high-level intrusive. Historic to recent placer gold is known in the region. Recent work by the property vendors indicates the presence of gold and diamond indicator minerals in the drainage surrounding the anomaly. Shear will investigate the property for kimberlitic/lamproitic intrusions, and base and precious metal potential.

Nevada Star Resource Corp. recently acquired approximately 8,000 acres of mining claims in the Nikolai nickel-platinum-copper belt in the southern Alaska Range. Between June 1996 and December 1998, Monty D. Moore and Associates and Nevada Star Resource Corp. of Seattle acquired mining rights to more than 81,600 acres and 8,580 acres of land, respectively, located on the southern flank of the Alaska Range. M.A.N. Resources Inc. will conduct exploration for platinum-group-element mineralization under a lease agreement with Nevada Star over a total of 2,212 mining claims. The Eureka Creek Project area is approximately 100 miles south-southeast of Fairbanks, and 156 miles northeast of Anchorage. Previous work identified platinum-group-element enriched sulfide concentrations in net textures at the base of the Tangle Lake and Landmark Gap ultramafic complex rocks and as disseminated nickelcopper sulfide mineralization in exposures along Broxson Gulch, Rainy Creek, Eureka Creek, and northern portions of the claim block. Meridian Geoscience Ltd. under contract with M.A.N. Resources, conducted a helicopter-borne magnetic-EM (electromagnetic) survey over the Eureka Creek and Tangle Lakes areas between June 12 and July 16, 1999 (fig. 11). A total of 1,984 line-miles were flown. Traverse flight line spacing was 328 feet $(100 \mathrm{~m})$ in the Tangle Lakes areas and 656 feet $(200 \mathrm{~m})$ in the Eureka Creek area. A number of promising electromagnetic conductors were discovered, particularly in the poorly exposed Tangle Lakes area. Geologic mapping included regional and detailed mapping to ascertain the distribution, orientation, and structural setting of important host lithologies. Ground geophysical surveys are planned to test the identified targets.

Fort Knox Gold Resources Inc. entered into an agreement with Inco Ltd. and American Copper \& Nickel Co. Inc. to increase its ownership from 20 to 100 percent in the Nikolai platinum-palladium-nickel property. Mineralization occurs in layered ultramafic-mafic intrusions and is hosted primarily by gabbro/norite, clinopyroxenite, and serpentinized dunite/wehrlite units. Mineralization varies from weakly disseminated to net-textured sulfides in ultramafic rocks and disseminated to massive sulfides in gabbro/ norite. The predominant sulfide phases are pyrrhotite, pentlandite and chalcopyrite. Platinum and palladium values are elevated in weakly mineralized intrusive rocks and reach as high as 0.45 ounces per ton platinum and 0.08 ounces per ton palladium in grab samples of massive sulfides. Core drilling near the Cantwell prospect intersected 17 feet of 3-5 percent sulfides with assay values of 0.020 ounces per ton platinum, 0.026 ounces per ton palladium, 0.8 percent nickel, and 0.5 percent copper.

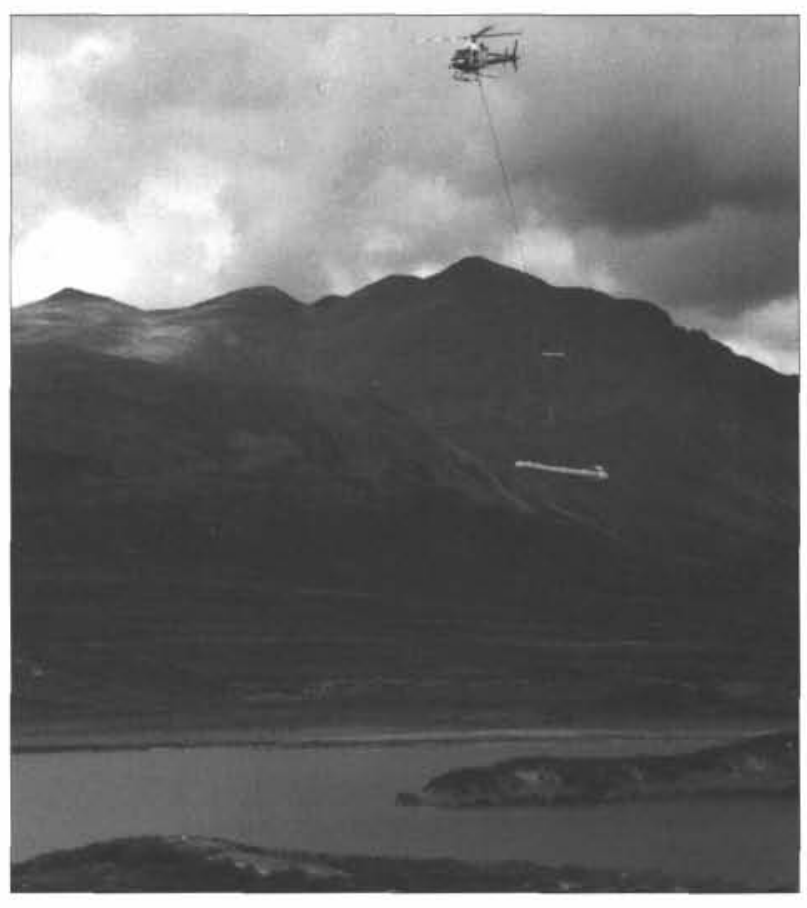

Figure 11. Era helicopter performing an airborne geophysical survey in the Tangle Lakes area, Alaska Range, for M.A.N. Resources Inc. M.A.N. Resources is currently exploring the area for platinum-groupelement mineralization associated with ultramafic to mafic intrusions. Photo provided by Lea Ann McDonald, Era Helicopters. 
Fort Knox Gold also exercised an option to acquire 100 percent interest in the Gunsite property, approximately 90 miles north of Anchorage in the Talkeetna Mountains. Potential copper-gold porphyry mineralization will be tested by an IP geophysical survey in the Prescott Point area.

\section{SOUTHWESTERN REGION}

Placer Dome Exploration Inc. cut back its exploration staff and continued evaluation of its 11.5-million-ounce gold resource at Donlin Creek near Flat with one coredrilling rig. Placer Dome confirmed the grade of the deposit. Placer Dome also conducted a small exploration program on Calista's Stuyahok prospect. Unfortunately, Placer Dome closed its Anchorage office during 1999, but continued exploring in southwestern Alaska and the Richardson district in the eastern interior region. A pre-feasibility study at Donlin Creek was postponed due to dismal gold prices.

Two companies new to Alaska also optioned land in the area. Fjordland Resources Ltd. optioned the Kisa prospect from Cominco Inc. The Kisa prospect is believed to be similar to NovaGold Resources' 1-million-ounce Shotgun gold deposit. Poseidon Minerals Ltd. acquired lease rights to earn a 100 percent interest in the Ganes Creek and Colorado Creek properties, formerly under option to Placer Dome. Ganes Creek occupies a large regional northeast-trending structure and the best placer gold on the property appears to occur at the intersections of related west-northwest and west-southwest structures. Over 260,000 ounces of placer gold has been produced from the Ganes Creek drainage, with much of the gold coarse, angular, and associated with quartz gangue. The Colorado Creek area has produced over 50,000 ounces of placer gold and the creek occupies a large, linear, north-northwest drainage interpreted as a deep-rooted regional structure. Poseidon conducted a mobile metal ion soil geochemical survey on both properties.

\section{SOUTHEASTERN REGION}

Kennecott Exploration continued exploration in and around the Greens Creek Mine. Abacus Minerals continued to assess the Niblack Mine near Ketchikan, and received a $\$ 2.5$ million long-term, non-convertible, lowinterest loan from the Economic and Development Assistance Fund in Ketchikan, Alaska. The funds are planned for further exploration and development at Niblack. A large group of claims was staked in the Wrangell Narrows area near Petersburg following an airborne geophysical survey sponsored by the State of Alaska, the federal government, several local communities, and Sealaska Corp.

Rubicon Minerals succeeded in outlining massive-sulfide mineralization with a ten-hole, 6,153-foot diamond core drilling and mapping program at its Palmer prospect near Haines. A new massive sulfide showing named the RW zone is 600 feet from the Lower Jarvis zone and 1,600 feet from the Upper Main zone along the same stratigraphic horizon. The RW zone was extended by drilling to 680 feet up-dip on sections 170 feet apart, with mineralization open in all directions. Drill results include 8.3 feet grading 5.85 percent zinc, 1.89 percent copper and 1 ounce per ton silver. Two holes drilled to test the MHC prospect did not intersect significant mineralization. The Cap showing was not tested in the 1999 program, but remains a target for future drilling. Another new high-grade surface-mineralized zone was discovered 150 feet above and in the stratigraphic hanging wall to the Main zone mineralization. Two grab samples assayed up to 18.75 percent zinc, 0.28 percent copper, and 0.56 ounces per ton silver.

Santoy Resources Ltd. signed an agreement with Stealth Ventures Ltd. to acquire 100 percent interest in the Salt Chuck copper-palladium-gold-silver deposit on Prince of Wales Island. First-year work commitments were minimal under the deal. Santoy compiled previous work data to better define a future exploration program.

\section{DEVELOPMENT}

Development expenditures dropped again in 1999 to $\$ 33.8$ million from $\$ 55.4$ million in 1998 , though plans at several operations call for increased development in 2000. Table 7 shows the regional employment and development investment, and table 8 compares the 1999 expenditures with those of the prior 17 years. Figure 12 shows the locations of selected development projects. No development projects were reported in the southwestern or Alaska Peninsula regions in 1999.

\section{NORTHERN REGION}

Most of the development in this region was related to Cominco Alaska's Red Dog zinc-lead-silver mine and the associated port, storage, and loading facility about 52 roadmiles to the west. At the mine, preparations were being made to optimize the milling operation in the next few years by modifying the flotation circuit. At the port, drainage lines were installed, and a new 3,500-foot conveyor was installed between the storage area and surge bins.

Minor amounts of development, such as stripping frozen overburden, were reported for some of the northern region placer mines.

\section{WESTERN REGION}

Viceroy Resources conducted a 2,400-foot, 23-hole drill program at the Illinois Creek gold-silver mine during a 
Table 7. Reported mineral development expenditures and employment in Alaska by commodity and region, 1999

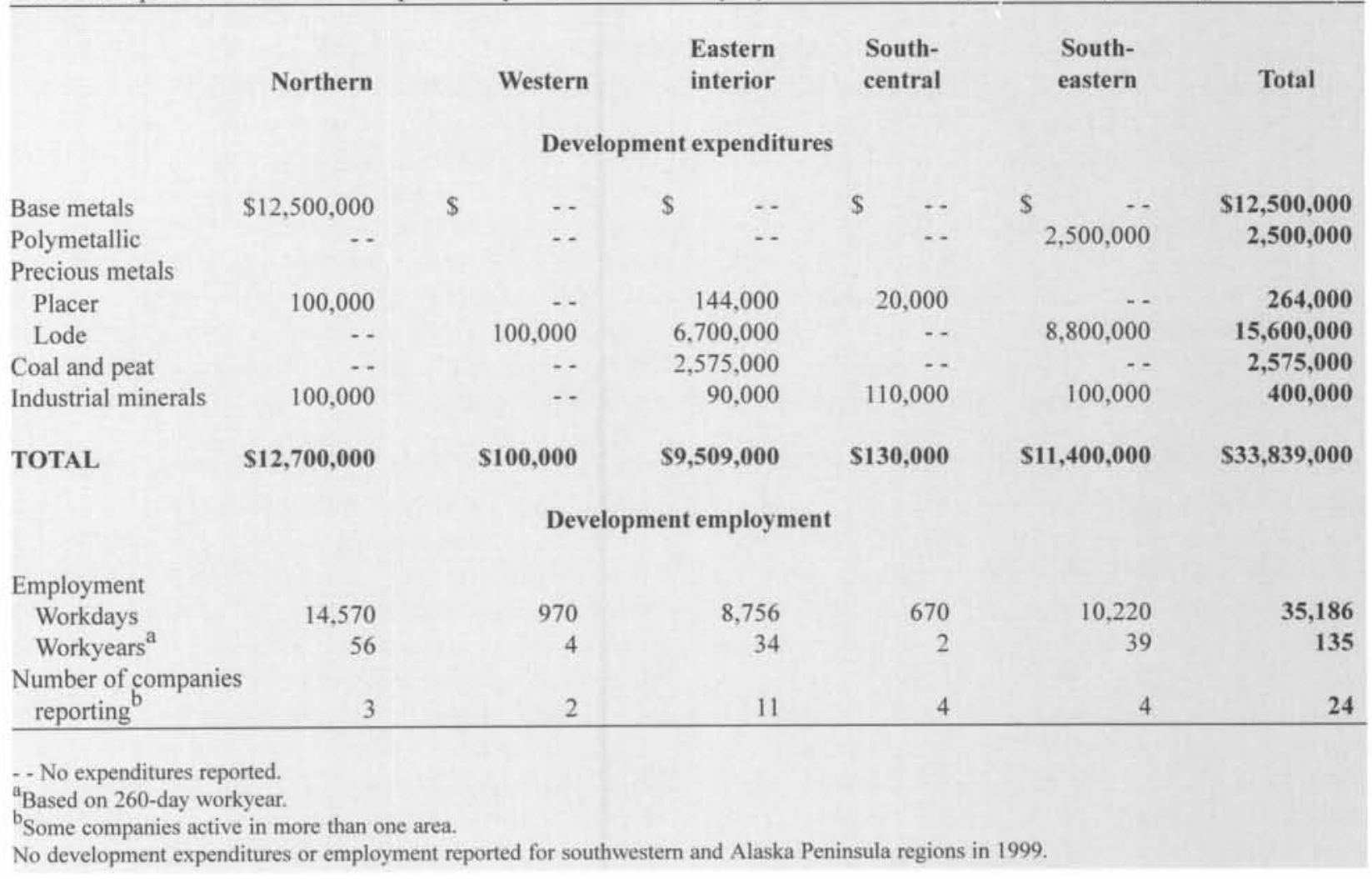

Table 8. Reported mineral development expenditures in Alaska by commodity, 1982-99

\begin{tabular}{|c|c|c|c|c|c|c|}
\hline & Base metals & Polymetallics & Precious metals & Industrial minerals & Coal and peat & Total \\
\hline 1982 & \$ $10,270,000$ & N/A & \$ $19,320,000$ & $\$ 4,251,000$ & $\$ 7,750,000$ & $41,591,000$ \\
\hline 1983 & $19,500,000$ & N/A & $7,112,500$ & $1,000,000$ & 250,000 & $27,862,500$ \\
\hline 1984 & $10,710,500$ & N/A & $15,058,555$ & 579,000 & $27,000,000$ & $53,348,055$ \\
\hline 1985 & $13,000,000$ & N/A & $16,890,755$ & $1,830,000$ & $2,400,000$ & $34,120,755$ \\
\hline 1986 & $3,260,800$ & $8,000,000$ & $12,417,172$ & 124,000 & 530,000 & $24,331,972$ \\
\hline 1987 & $38,080,000$ & $48,000,000$ & $13,640,848$ & 188,000 & 342,000 & $100,250,848$ \\
\hline 1988 & $165,500,000$ & $69,000,000$ & $40,445,400$ & - & $\ldots$ & $274,945,400$ \\
\hline 1989 & $118,200,000$ & 411,000 & $6,465,350$ & $7,000,000$ & $2,196,000$ & $134,272,350$ \\
\hline 1990 & . & $4,101,000$ & $7,136,500$ & 30,000 & $3,079,000$ & $14,346,500$ \\
\hline 1991 & . & $8,000,000$ & $14,994,350$ & 262,000 & $2,318,000$ & $25,574,350$ \\
\hline 1992 & 80,000 & $4,300,000$ & $23,151,300$ & 404,000 & $1,655,000$ & $29,590,300$ \\
\hline 1993 & . & $10,731,136$ & $15,103,000$ & 433,500 & $1,400,000$ & $27,667,636$ \\
\hline 1994 & $10,000,000$ & $5,000,000$ & $27,392,850$ & 5,000 & $2,545,000$ & $44,942,850$ \\
\hline 1995 & $11,200,000$ & $9,590,000$ & $127,165,750$ & 426,000 & 200,000 & $148,581,750$ \\
\hline 1996 & $60,000,000$ & $60,100,000$ & $273,042,000$ & 495,000 & 400,000 & $394,037,000$ \\
\hline 1997 & $133,880,000$ & $7,300,000$ & $26,299,000$ & 500,000 & 410,000 & $168,389,000$ \\
\hline 1998 & $28,000,000$ & $5,600,000$ & $15,602,000$ & $5,355,000$ & 850,000 & $55,407,000$ \\
\hline 1999 & $12,500,000$ & $2,500,000$ & $15,864,000$ & 400,000 & $2,575,000$ & $33,839,000$ \\
\hline TOTAL & $\$ 634,181,300$ & $\$ 242,633,136$ & $\$ 677,101,330$ & $\$ 23,282,500$ & $\$ 55,900,000$ & $\$ 1,633,098,266$ \\
\hline
\end{tabular}

$\mathrm{N} / \mathrm{A}=$ Figures not available prior to 1986 .

- Not reported. 


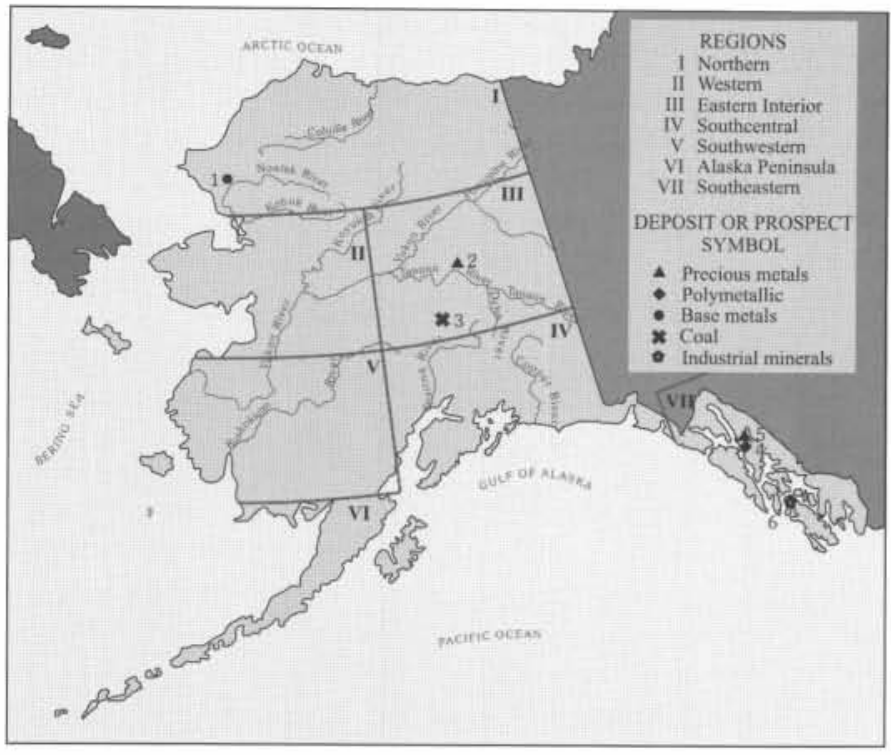

Figure 12. Selected mineral development projects in Alaska, 1999.

\author{
I Northern Region \\ 1. Red Dog Mine - Cominco Alaska Inc. (mill \\ circuit/port storage)
}

\section{Western Region}

\section{Eastern Interior Region}

2. Fairbanks area

a. Fort Knox Mine - Kinross Gold Corp. (drilling, tailing dam construction)

b. Several open-pit and underground placer mines

c. Ryan Lode Mine \& True North Mine, Kinross Gold Corp.

3. Two Bull Ridge operation-Usibelli Coal Mine Inc. (drilling, road construction)

\section{Southcentral Region}

\section{Southwestern Region}

\section{Alaska Peninsula Region}

\section{Southeastern Region}

4. Greens Creek Mine-Kennecott Mineral Co./ Hecla Mining Co. (access drifting, underground drilling)

5. A-J Mine-Kvaerner Environmental (reclamation)

6. Kensington Mine - Coeur Alaska (optimization studies) due-diligence development program while the mine was on care-and-maintenance status, but no other development projects were reported.

\section{EASTERN INTERIOR REGION}

Most of the development was associated with activity at Fairbanks Gold Mining Inc.'s (FGMI) Fort Knox, True North, and Ryan Lode mines. FGMI is a wholly-owned subsidiary of Kinross Gold Corporation.

Activity at Fort Knox Mine consisted of 2,500 feet of reverse-circulation (RVC) drilling and 5,768 feet of core drilling for development in the pit; construction associated with dewatering of the pit; and random waste storage. At the recently acquired True North property development drilling included 18,695 feet of RVC drilling and 5,064 feet of core drilling for confirmation of reserves $(7.242$ million tons of 0.063 ounce per ton ore containing 459,000 ounces of gold) and for baseline hydrology data. Plans are to invest about 30 million dollars to rebuild the access road, and mine the Hindenberg Pit and East Pit at 30,000 tons per day as "gravel pits," trucking about 10,000 tons of ore daily to the Fort Knox mill to blend with about 30,000 tons of Fort Knox ore.

At Ryan Lode west of Fairbanks about 8,000 feet of RVC drilling and 5,957 feet of core drilling were completed for hydrologic and baseline studies, and to better understand the oxide/sulfide boundary of the deposit. The drilling was also conducted to better define and confirm a previously stated geologic resource totaling 2.4 million ounces, with a defined reserve of 820,000 ounces of gold in 14.6 million tons of rock. Kinross has also voluntarily begun $\$ 100,000$ worth of site remediation at Ryan Lode to address perceived environmental problems that occurred prior to their acquisition of the property. Current reserves are 2.4 million tons grading 0.089 ounces of gold per ton, for a contained 214,000 ounces. Further drilling and permitting will continue in 2000 to examine the feasibility of trucking ore from Ryan Lode to the mill at Fort Knox.

Eight placer mines reported minor development work such as stripping frozen overburden and drilling, and several gravel pits and peat operations reported some development.

At the Usibelli Coal Mine near Healy, preparations are being made to move the 2,000-ton Ace-In-The-Hole dragline from the Poker Flats Pit, where it has operated to remove overburden for the last few years, to a new mining lease across the river at Two Bull Ridge. Road construction to access the lease cut several coal seams, and the sale of the coal served to offset the development expenses.

\section{SOUTHCENTRAL REGION}

The only development reported in this region was minor stripping at two placer mines, and development of a gravel pit near Anchorage. 


\section{SOUTHEASTERN REGION}

Coeur-Alaska Inc. continued to study the optimization of the Kensington Mine 45 miles north of Juneau, and to apply for permit modifications to take into account the changing plans for the operation.

Kvaerner Environmental continued with reclamation and rehabilitation of the historic Alaska-Juneau (A-J) Mine in downtown Juneau, and anticipates completion of the main tasks in 2000. Kvaerner is also conducting a comprehensive risk-based assessment at the mine and will establish a fund for long-term environmental monitoring.

Kennecott/Hecla reported about 5,000 feet of development drifting and underground drilling at their Greens Creek Mine.

\section{PRODUCTION}

The total value of production from Alaska's mines and quarries in 1999 was $\$ 1,032.9$ million, up 12 percent from the $\$ 920.2$ million documented in 1998. Most of the increase was due to a full year of mining at the higher rate allowed by the Production Rate Increase project at Red Dog Mine. The Red Dog zinc-lead-silver mine and the Greens Creek polymetallic mine both produced record amounts of concentrates in 1999, more than compensating for low metal prices, the decline in the amount of gold produced, and the low gold price.
For the first time in many years there was no production from the major placer deposits in Nome, and many long-time placer miners opted to sit out the year due to the extremely low gold prices. The Nixon Fork underground gold mine was put on care-and-maintenance status in June, and the Illinois Creek open-pit mine continued to rinse the existing heaps, with no additional placement of new ore.

Table 9 shows the quantity and value of metals and materials produced from 1997 to 1999. Table 10 lists the mines and miners that completed an Alaska Placer Mining

Table 9. Estimated mineral production in Alaska, 1997-99a

\begin{tabular}{|c|c|c|c|c|c|c|}
\hline \multirow[b]{2}{*}{ Metals } & \multicolumn{3}{|c|}{ Quantity } & \multicolumn{3}{|c|}{ Estimated values ${ }^{b}$} \\
\hline & 1997 & 1998 & 1999 & 1997 & 1998 & 1999 \\
\hline Gold (ounces) & 590,516 & 594,191 & $517,890^{\mathrm{c}}$ & $\$ 207,287,000$ & $\$ 174,621,000$ & $\$ 144,262,000$ \\
\hline Silver (ounces) & $14,401,165$ & $14,856,000$ & $16,467,000$ & $70,710,000$ & $82,154,000$ & $85,628,000$ \\
\hline Copper (tons) & 1,720 & 1,900 & 2,100 & $3,543,000$ & $2,850,000$ & $2,982,000$ \\
\hline Lead (tons) & 88,560 & 102,887 & 125,208 & $49,593,000$ & $49,386,000$ & $57,596,000$ \\
\hline Zinc (tons) & 419,097 & 549,348 & 643,642 & $494,888,000$ & $505,400,000$ & $630,769,000$ \\
\hline Subtotal & & & & $\$ 826,021,000$ & $\$ 814,411,000$ & $\$ 921,237,000$ \\
\hline \multicolumn{7}{|l|}{ Industrial minerals } \\
\hline Jade and soapstone (tons) & 2.0 & 2.0 & 2.0 & $\$ \quad 25,000$ & $\$ \quad 25,000$ & 25,000 \\
\hline Sand and gravel (million tons) & 13.8 & 12.40 & 10.6 & $51,913,000$ & $57,280,000$ & 52.418 .000 \\
\hline Rock (million tons) & 3.2 & 1.64 & 2.34 & $20,000,000$ & $14,041,000$ & $18,010,000$ \\
\hline Subtotal & & & & \$ $71,938,000$ & S $71,346,000$ & \$ $70,453,000$ \\
\hline \multicolumn{7}{|l|}{ Energy minerals } \\
\hline Coal (tons) & $1,446,000$ & $1,339,000$ & $1,560,000$ & $\$ 38,048,000$ & $\$ 35,233,000$ & $41,048,000$ \\
\hline Peat (cubic yards) & 38,500 & 38,000 & 38,000 & 192,000 & 190,000 & 165,000 \\
\hline Subtotal & & & & S $38,240,000$ & S $35,423,000$ & $41,213,000$ \\
\hline TOTAL & & & & $\$ 936,199,000$ & $\$ 921,180,000$ & $\$ 1,032,903,000$ \\
\hline
\end{tabular}

aProduction data from DGGS questionnaires, phone interviews with mine and quarry operators, Alaska Department of Transportation and Public Facilities, and federal land management agencies.

bValues for selected metal production based on average prices for each year; for 1999 -gold (\$278.70/ounce) unless other value provided by operator; silver $(\$ 5.20 /$ ounce); copper $(\$ 0.71 / \mathrm{lb})$; zinc $(\$ 0.49 / \mathrm{lb})$; lead $(\$ 0.23 / \mathrm{lb})$. All other values provided by mine operators. Values rounded to nearest $\$ 1,000$.

'Hardrock gold 447,662 ounces, placer 70,228 ounces. 
Table 10. Companies and individuals reported to be producing metal in Alaska, 1999

\section{Operator}

\author{
Gold Dust Mines \\ Lounsbury, Jim \\ Paradise Mining \\ Tri-Con Mining \\ Cominco Alaska Inc.
}

Vial, Dave

Vial, Mike

Taiga Mining

Rosander, Ron

Dakota Mining Corp.

Benesch, George

Mullikin, Donald

Magnuson, Manzie

Real del Monte Mining Corp.

Gibson, Wayne

High Bench

Krutzsch, Betty

Massie, Perry

Olsen, Dave

Pettigrew

Pomrenke, Steve

Walsh, Paul

Kralik, Janos

Tweet, Bruce \& Doug

Clay, Barry

Tryck, Keith

Decker, James

Kiehl, Don

Totat Mining

Catt, Bruce

Fulton, Gordon

Glassburn, Don

Koppenberg, Sam

Lapp, Ed \& Sons

Lines, Lester

Olsen, Steven

Smith, David Jr.

Stone, James

The Mining Co.

Willis Mine Service

Wrede, Ronald

Jensen, Dan

Andresen, John

Bergman, Kevin

Cornelius, Fred

Fairbanks Gold Mining Inc.

Goodwin, Robert

Hassel, Jerry

Hopen, Alf

Jobaric Enterprises

Knudsen, Richard

\section{Creek}

NORTHERn REgion

$\begin{array}{ll}\text { Big } & \text { Chandalar } \\ \text { Union Gulch } & \text { Koyukuk } \\ \text { Birch } & \text { Koyukuk } \\ \text { Nolan } & \text { Koyukuk } \\ \text { Red Dog Mine } & \text { Noatak }\end{array}$

\section{Western Region}

Candle

Dry

Colorado

Illinois Creek Mine

Coffee

Noxapaga

Candle

Nixon Fork Mine McGrath

Golden

Anvil

Specimen Gulch

Cripple

Canyon

Anvil

Tripple

Gold Run

Gold Run

Windy

Swift

Ophir

\section{Fairhaven}

Fairhaven

Hughes

Innoko

Kaiyuh

Kougarok

Kougarok

McGrath

Melotzitna

Nome

Nome

Nome

Nome

Nome

Nome

Nome

Port Clarence

Port Clarence

Ruby

Ruby

\section{Type $^{\text {a }}$}

O/P Placer

O/P Placer

O/P Placer

$\mathrm{O} / \mathrm{P}$ and $\mathrm{U} / \mathrm{G}$ Placer

HR O/P (zinc-lead-silver)

O/P Placer

$\mathrm{O} / \mathrm{P}$ Placer

$\mathrm{O} / \mathrm{P}$ Placer

$\mathrm{O} / \mathrm{P}$ Placer

HR O/P (gold-silver)

$\mathrm{O} / \mathrm{P}$ Placer

$\mathrm{O} / \mathrm{P}$ Placer

$\mathrm{O} / \mathrm{P}$ Placer

HR U/G (gold-copper)

$\mathrm{O} / \mathrm{P}$ Placer

O/P Placer

O/P Placer

$\mathrm{O} / \mathrm{P}$ Placer

O/P Placer

O/P Placer

$\mathrm{O} / \mathrm{P}$ Placer

O/P Placer

O/P Placer

$\mathrm{O} / \mathrm{P}$ Placer

O/P Placer

O/P Placer

O/P Placer

O/P Placer

$\mathrm{O} / \mathrm{P}$ Placer

O/P Placer

$\mathrm{O} / \mathrm{P}$ Placer

$\mathrm{O} / \mathrm{P}$ Placer

O/P Placer

$\mathrm{O} / \mathrm{P}$ Placer

$\mathrm{O} / \mathrm{P}$ Placer

$\mathrm{O} / \mathrm{P}$ Placer

O/P Placer

O/P Placer

$\mathrm{O} / \mathrm{P}$ Placer

$\mathrm{O} / \mathrm{P}$ Placer

O/P Placer

O/P Placer

$\mathrm{O} / \mathrm{P}$ Placer

$\mathrm{O} / \mathrm{P}$ Placer

O/P Placer

H/R O/P (gold)

O/P Placer

$\mathrm{O} / \mathrm{P}$ Placer

$\mathrm{O} / \mathrm{P}$ Placer

$\mathrm{O} / \mathrm{P}$ Placer

$\mathrm{O} / \mathrm{P}$ Placer

aO/P=Open-pit; HR=Hard-rock; U/G=Underground. 


\section{Operator}

Krzykoski, Ben

Largent, Walter

Las, Allen

Loud, Dick

Miscovich, Andy

Moore, Roger

Polar Mining

Read, Donald

Roberts, Mike

Roman, Ron

Stein, Don

Tweiten, Oscar

Yellow Eagle

45-Pup Mining

Bickell, Harvey

Carr, Brad

GeoQuest

Hayden, Forest

Maxwell Mining

Reed, Scott

Regner, Leo

Roberts, Robert

Schofield, Walter

Seuffert, George Jr.

Tallini, Roger

Taylor's Mining

Treesh, James

Cassiterite Placers

Hodges, Jay

Ott, Richard

Wilder, Richard

Wood, James

AK Placer Dev.

Eaves, Samuel

Crow Creek Mining

Girdwood Mining Co.

Hoffman Mining

Willard, Gerald

Miller, Jerry

Mrak Placer Mine

LaCross, Jack

Lake Creek Placers

Chase Bros

Matter, Mark

Nyac Placer

Wilmarth, Richard

Clarke-Wiltz

Little Creek

Lyman Resources

Plano, Ed
Creek

Big Eldorado

Ester

No Grub

Chatanika

Wolf

Ready Bullion

Fox Goldstream

Treasure

Dome/ Little Eldorado

Last Chance

Dome

Chatham

Cripple

Fortymile

Walker Fork

Chicken

Chicken

Kal

$\mathrm{Kal}$

Fortymile

Lilliwig

Chicken

Fortymile

Chicken

South Fork

Fortymile

Cherry/No Name

Tofty

American

Omega

Boulder

Little Boulder

Livengood

Warwick Gulch
District

Fairbanks

Fairbanks

Fairbanks

Fairbanks

Fairbanks

Fairbanks

Fairbanks

Fairbanks

Fairbanks

Fairbanks

Fairbanks

Fairbanks

Fairbanks

Fortymile

Fortymile

Fortymile

Fortymile

Fortymile

Fortymile

Fortymile

Fortymile

Fortymile

Fortymile

Fortymile

Fortymile

Fortymile

Fortymile

Hot Springs

Hot Springs

Hot Springs

Hot Springs

Hot Springs

Tolovana

Tolovana
Type $^{\mathrm{a}}$

O/P Placer

$\mathrm{O} / \mathrm{P}$ Placer

O/P Placer

O/P Placer

$\mathrm{O} / \mathrm{P}$ Placer

$\mathrm{O} / \mathrm{P}$ Placer

$\mathrm{O} / \mathrm{P}$ Placer

U/G Placer

U/G Placer

O/P Placer

O/P Placer

$\mathrm{O} / \mathrm{P}$ Placer

$\mathrm{O} / \mathrm{P}$ Placer

O/P Placer

O/P Placer

$\mathrm{O} / \mathrm{P}$ Placer

$\mathrm{O} / \mathrm{P}$ Placer

$\mathrm{O} / \mathrm{P}$ Placer

O/P Placer

$\mathrm{O} / \mathrm{P}$ Placer

O/P Placer

$\mathrm{O} / \mathrm{P}$ Placer

$\mathrm{O} / \mathrm{P}$ Placer

O/P Placer

O/P Placer

$\mathrm{O} / \mathrm{P}$ Placer

$\mathrm{O} / \mathrm{P}$ Placer

O/P Placer

O/P Placer

$\mathrm{O} / \mathrm{P}$ Placer

$\mathrm{O} / \mathrm{P}$ Placer

O/P Placer

$\mathrm{O} / \mathrm{P}$ Placer

O/P Placer

\section{Southcentral Region}

$\begin{array}{lll}\text { Crow } & \text { Anchorage } & \text { O/P Placer } \\ \text { Crow } & \text { Anchorage } & \text { O/P Placer } \\ \text { Chistochina } & \text { Chistochina } & \text { O/P Placer } \\ \text { Bear } & \text { Hope } & \text { O/P Placer } \\ \text { Willow/Homestake } & \text { Willow Creek } & \text { O/P Placer } \\ \text { Willow } & \text { Willow Creek } & \text { O/P Placer } \\ \text { Willow } & \text { Yentna } & \text { O/P Placer } \\ \text { Lake } & \text { Yentna } & \text { O/P Placer }\end{array}$

\section{SOUTHWESTERN REgiON}

$\begin{array}{lll}\text { Flat } & \text { Anvik } & \text { O/P Placer } \\ \text { Marvel } & \text { Aniak } & \text { O/P Placer } \\ \text { Bear } & \text { Aniak } & \text { O/P Placer } \\ \text { Chicken } & \text { Iditarod } & \text { O/P Placer } \\ \text { Podesie/Ganes } & \text { Innoko } & \text { O/P Placer } \\ \text { Little } & \text { Innoko } & \text { O/P Placer } \\ \text { Queen } & \text { Innoko } & \text { O/P Placer } \\ \text { Anvil } & \text { Innoko } & \text { O/P Placer }\end{array}$

Kennecott/Hecla

SOUtheAstern RegioN

Greens Creek Mine

Admiralty Island

U/G (zinc-lead-silver-gold)

${ }^{\mathrm{a}} \mathrm{O} / \mathrm{P}=$ Open-pit; HR=Hard-rock; $\mathrm{U} / \mathrm{G}=$ Underground. 
Application for the 1999 season, and were thought to have had at least some production. Figures 13, 14, and 15 show historic production of sand and gravel, gold, and coal. Selected 1999 Alaskan production sites are shown in figure 16.

Metals, with a value of $\$ 921.2 \mathrm{mil}-$ lion, account for 89 percent of the total production, followed by industrial minerals (rock, sand and gravel) with a value of $\$ 70.5$ million ( 7 percent), and coal and peat at $\$ 41.2$ million (4 percent).

As in the last few years (and for the foreseeable future) zinc was the most valuable metal produced in Alaska in 1999. The 643,642 dry short tons produced had a gross value of $\$ 630.77$ million, or 68 percent of the total \$921.1 million metal value. Gold, at 517,890 ounces with a value of $\$ 144.3$ million or 16 percent ranked second, followed by silver ( $16.47 \mathrm{mil}-$ lion ounces with a value of $\$ 85.63$ million, 9 percent), 125,208 tons of lead ( $\$ 57.6$ million and 6 percent), and 2,100 tons of copper ( $\$ 3$ million and 0.3 percent).

Table 11 shows the average value of the metal prices used in this report over the last 7 years. The average price for most of the metals produced in Alaska, with the exception of zinc, has declined in the last three years.

These production estimates are from 187 questionnaires returned from miners, Native corporations and municipalities, supplemented by about 90 phone surveys. Additional information was derived from Alaska Placer Mining Applications (APMAs) submitted to the Division of Mining, Land \& Water, but a number of placer miners could not be contacted, so the placer mine production is estimated to be conservative. There may also be some operations listed in table 10 that elected not to mine due to the low price of gold.

The authors wish to thank the Alaska Railroad Corporation (ARR), the Alaska Department of Natural Resources Division of Mining, Land \&

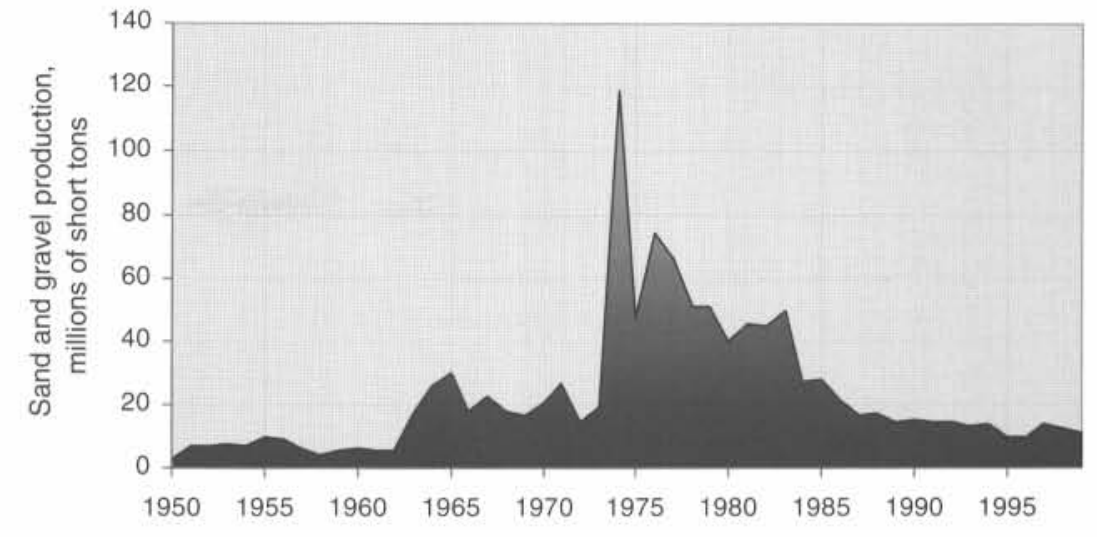

Figure 13. Sand and gravel production in Alaska, 1950-99.

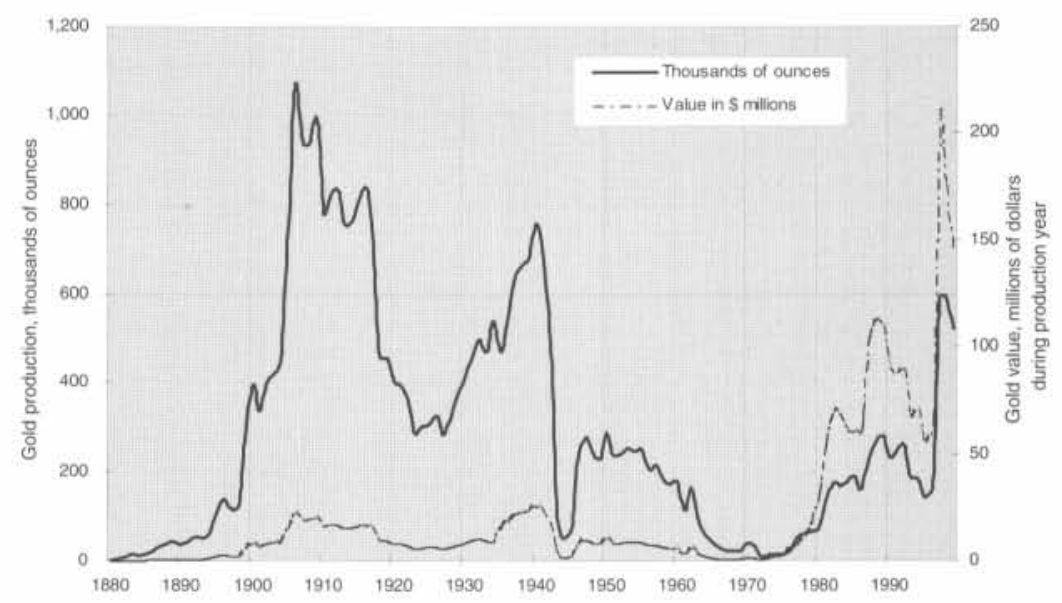

Figure 14. Amount and value of gold production in Alaska, 1880-1999.

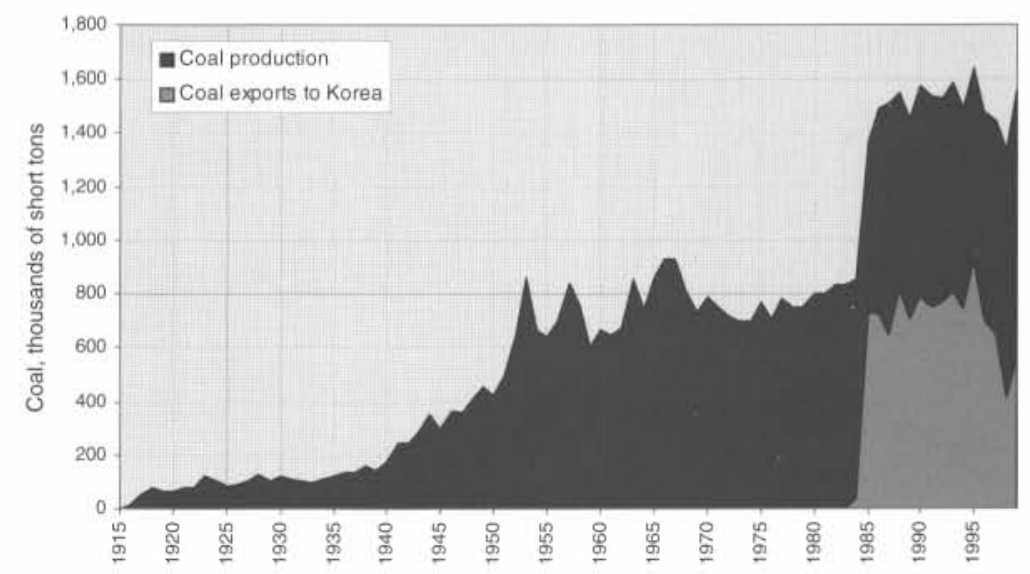

Figure 15. Coal production in Alaska, 1915-99, including exports to Korea. 


\section{Northern Region}

1. Cominco Alaska Inc. Red Dog Mine, Noatak district-zinc-lead-silver (germanium)

2. Tri-Con Mining Alaska Inc. Swede Bench Nolan Creek placer property, KoyukukNolan district-gold

3. Prudhoe Bay and Kuparuk pits (numerous) - sand and gravel

II Western Region

4. Dakota Mining Co. Illinois Creek Mine, Koyukuk-Hughes district-gold-silver

5. Real del Monte Mining Corp., Nixon Fork Mine McGrath-McKinley district-goldcopper-silver-bismuth

\section{Eastern Interior Region}

6. Alaska Placer Development, LivengoodTolovana district-gold-silver

7. Yellow Eagle Mining Inc., Fairbanks district-gold-silver

8. Polar Mining Inc., Fairbanks districtgold-silver-screened aggregate

9. Kinross Gold Corp. Fort Knox Mine, Fairbanks district - gold-silver

10. Usibelli Coal Mine Inc., Bonnifield district - coal

\section{Southcentral Region}

11. Landscape Supply Corp., Hatcher Pass district-topsoil-peat

12. Hermon Brothers Construction Co., Anchorage district-sand and gravel

Figure 16. Selected production projects, 1999.

Water (DMLW), the Department of Transportation \& Public Facilities (DOTPF), the U.S. Bureau of Land Management (BLM), and the U.S. Forest Service (USFS) for providing information for this section of the report.

Some respondents reported costs and unit values, but unless selling costs were expressly provided, the metal values were computed from the weekly averages on the London Exchange, and do not take into account mining, shipping, smelting, or other costs incurred by the reporting company.

Tables 12 and 13 show the gold production by region of the state, and the percentage of placer production by small, medium, and large mines. Hardrock gold production declined from 498,892 ounces in 1998 to 447,662 ounces in 1999, while placer gold production declined to 70,228 ounces from 95,299 ounces a year earlier. The closure of the large Alaska Gold Company mine at Nome accounted for much of the placer decline, and the closures of Illinois Creek Mine and Nixon Fork Mine accounted for the decline in hardrock production.

Tables 14 and 15 show the value and regional importance of sand and gravel and rock production. The amount of sand and gravel used in the state is highly influenced by

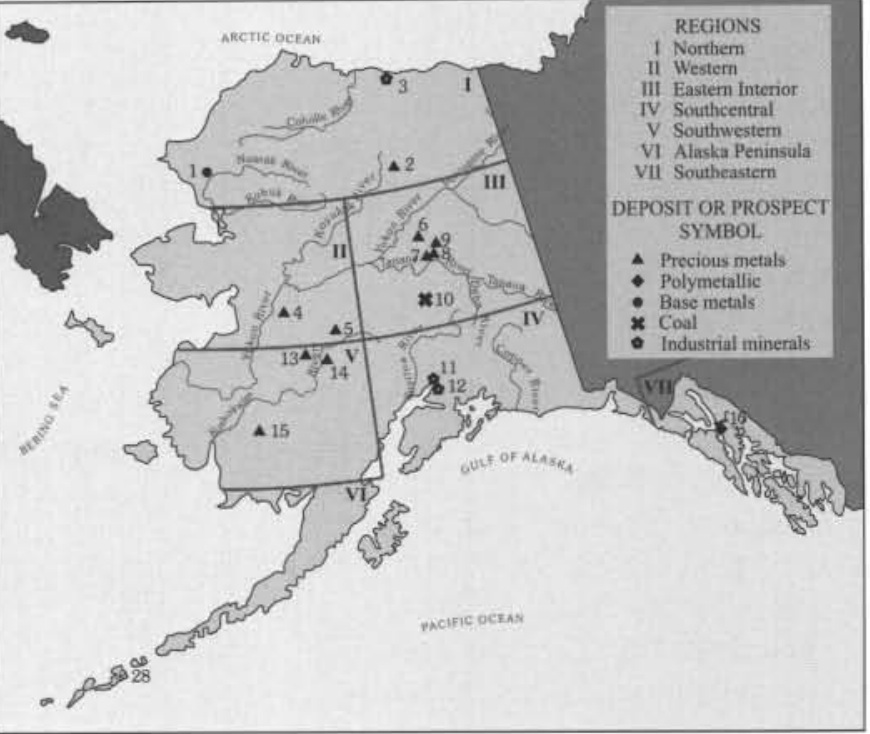

V Southwestern Region

13. Clark-Wiltz Partnership, Innoko district - gold-silver

14. Manzie Magnuson, McGrath-McKinley district - goldsilver

15. NYAC Mining Co., Nyac district-gold-silver

\section{Alaska Peninsula Region}

VII Southeastern Region

16. Kennecott Minerals Co./Hecla Mining Co., Greens Creek Mine, Juneau-Admiralty district-silver-zinc-gold-leadcopper

Table 11. Average metal prices, 1993-99

\begin{tabular}{llllll}
\hline & $\begin{array}{c}\text { Gold } \\
(\$ / \mathbf{o z})\end{array}$ & $\begin{array}{c}\text { Silver } \\
\mathbf{( \$ / 0 z )}\end{array}$ & $\begin{array}{c}\text { Copper } \\
\mathbf{( \$ / l b )}\end{array}$ & $\begin{array}{c}\text { Zinc } \\
\mathbf{( \$ / l b )}\end{array}$ & $\begin{array}{c}\text { Lead } \\
\mathbf{( \$ / / b )}\end{array}$ \\
1993 & 359.00 & 4.30 & 0.87 & 0.44 & 0.18 \\
1994 & 386.00 & 5.41 & 1.05 & 0.45 & 0.35 \\
1995 & 395.00 & 5.43 & 1.33 & 0.48 & 0.34 \\
1996 & 387.60 & 5.19 & 1.03 & 0.49 & 0.37 \\
1997 & 330.76 & 4.91 & 1.03 & 0.59 & 0.28 \\
1998 & 293.88 & 5.53 & 0.75 & 0.46 & 0.24 \\
1999 & 278.70 & 5.20 & 0.71 & 0.49 & 0.23 \\
\hline
\end{tabular}

the amount of road construction, and also by activity in the North Slope oilfields. In 1999 most of the 10.6 million tons was used in road construction, and had a computed value of \$52.4 million. Likewise crushed rock and riprap use has declined substantially as U.S. Forest Service needs have declined. Only 2.3 million tons of rock, with a computed value of $\$ 18$ million, was used throughout the state in 1999, a slight increase over the previous year, but down dramatically from the average of 13 million tons used in the mid 1990s. 
Coal production increased slightly in 1999 to $1,560,000$ short tons, and though shipments for export to Korea, 563,000 short tons, were not as high as expected, they exceeded the 409,000 short tons shipped in 1998. Peat production remained at about the same level as in past years.

\section{NORTHERN REGION}

\section{Metals}

Cominco's Red Dog Mine produced 574,111 tons of zinc, 97,756 tons of lead, and an estimated 6 million ounces of silver in 1999, accounting for almost 70 percent of all metal produced in Alaska. When exploration and development are included, the Red Dog Mine area accounts for a full 59 percent of the total value of Alaska's mineral industry.

Red Dog Mine is located in the Main Zone, one of at least five deposits known in the Red Dog mining district (see the "Exploration" section). In 1999 about 3.283 million tons of ore was milled, with an average grade of 21.3 percent zinc, 5.2 percent lead, with 2.7 ounces of silver per ton. The average zinc and lead contents of the concentrates were 55.2 percent and 58.5 percent respectively. Table 16 shows details of production for the past 11 years.

The Red Dog operation (fig. 17) employs 539 people, with an additional 60 at the port site during the short summer shipping season. Cominco employs 419 people in the mining and milling process, of whom about 60 percent are local corporation shareholders. NANA, the local regional Native corporation, has the contract for housekeeping and services in a NANA-Marriott joint venture, and at yearend entered into the NANA-Lynden joint venture to transport the ore concentrates to the port, 52 miles away on the Chukchi Sea coast south of Kivalina. NANAMarriott has 49 employees, and NANA-Lynden has 59.

\begin{tabular}{|c|c|c|c|c|c|c|c|c|c|}
\hline \multirow[t]{2}{*}{ Region } & \multicolumn{3}{|c|}{ Number of operators } & \multicolumn{3}{|c|}{ Production in ounces of gold } & \multicolumn{3}{|c|}{ Number of employees } \\
\hline & 1997 & 1998 & 1999 & 1997 & 1998 & 1999 & 1997 & 1998 & 1999 \\
\hline Northern & 4 & 4 & 5 & 537 & 731 & 1,262 & 12 & 9 & 8 \\
\hline Western & 24 & 24 & 21 & 104,297 & 113,066 & 36,377 & 324 & 254 & 114 \\
\hline Eastern Interior & 75 & 72 & 57 & 423,676 & 413,959 & 392,237 & 548 & 475 & 443 \\
\hline Southcentral & 6 & 9 & 8 & 971 & 543 & 305 & 12 & 15 & 14 \\
\hline Southwestern & 11 & 7 & 8 & 5,070 & 5,320 & 7,577 & 57 & 27 & 28 \\
\hline Southeastern & 3 & 1 & 2 & 55,965 & 60,572 & 80,132 & 277 & 275 & 280 \\
\hline TOTAL & 123 & 117 & 101 & 590,516 & 594,191 & 517,890 & 1,230 & 1,055 & 887 \\
\hline
\end{tabular}

Table 13. Production for selected Alaska placer gold mines, 1993-99

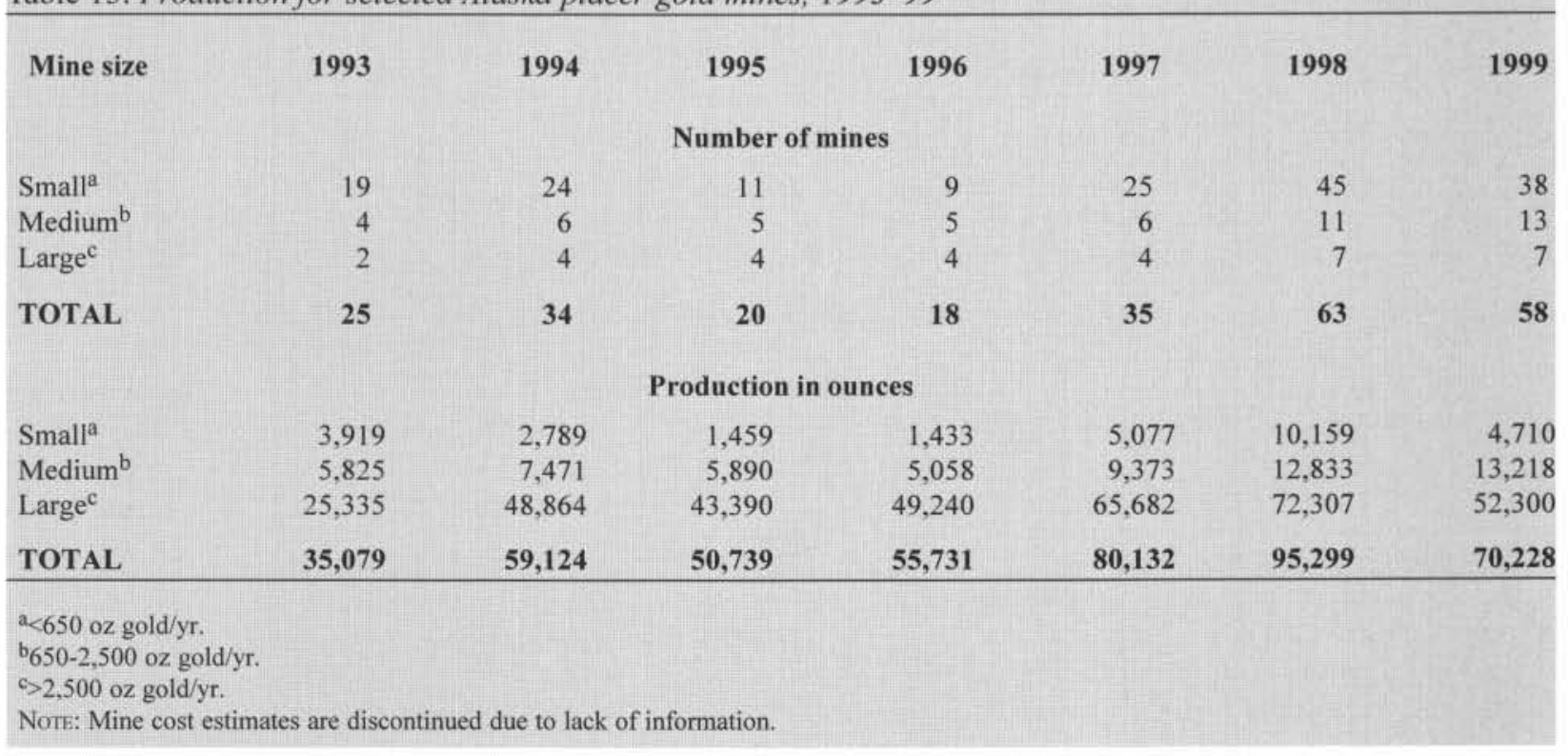


Except for those employees housed at the port site, most are accommodated at "The Doghouse" at the mine.

The mine is a conventional open pit operation, with a jaw crusher and a gyratory crusher at the pit exit. These crushers feed the minus-six-inch coarse ore stockpile, which is trucked to mill. Primary and secondary grinding with a semi-autogenous grinding (SAG) mill and ball mill convert the ore to 80 percent passing 65 microns to liberate the fine-grained ore. Tower mills are used in the regrind section of the mill circuit, which converts 80 percent of the zinc and lead concentrates to less than 22 and $19 \mathrm{mi}-$ crons respectively.

The water for the flotation is treated to maximize efficiency, and naturally occurring carbon and sulfur are removed from the concentrate by a preflotation procedure. Both conventional and column cells are used for flotation, which occurs at an almost neutral pH. Most of the variables can be manipulated from a control panel using on-stream analysis for real-time assay information.

Due to the long winter, water is at a premium much of the year, and water in Red Dog Creek contains high levels of dissolved metals in its natural state, so it must be closely monitored to avoid environmental problems. The mine is a "zero discharge" facility.

Power for the mine is presently provided by diesel generators, but the federal Environmental Protection Agency is attempting to restrict the use of additional power units. Cominco is investigating the use of natural gas derived from the shale basins that contain the ore, and is also looking at the possibility of mine-mouth power from the high-rank coals of the Northwest Arctic coalfields about 60 miles north of the mine. The Arctic Slope Regional Corporation owns some of the coal and has been exploring the export potential for several years, but the lack of any port facility has been a severe constraint. Access to the loading facility at the Red Dog port could be the key to opening the Northwest Arctic coalfields.

During the short summer shipping season up to 100 additional employees are located at the port, to assist with the offloading of supplies and to load concentrates into 35,000 - to 88,000 -ton ships. At present two Foss Maritime barges with on-deck Caterpillar 988 loaders are

Table 14. Reported sand and gravel production and industry employment in Alaska by region, 1999

\begin{tabular}{|c|c|c|c|c|c|}
\hline Region & $\begin{array}{l}\text { Companies and } \\
\text { agencies reporting }\end{array}$ & Tons & $\begin{array}{l}\text { Estimated unit } \\
\text { value }(\$ / \text { ton })^{\mathrm{b}}\end{array}$ & $\begin{array}{l}\text { Total } \\
\text { value }\end{array}$ & $\begin{array}{c}\text { Estimated number } \\
\text { of employees }\end{array}$ \\
\hline Northern & 4 & $1,728,911$ & 4.72 & $8,159,062$ & 107 \\
\hline Western & 3 & 718,055 & 5.36 & $3,845,823$ & 33 \\
\hline Eastern Interior & 5 & $2,663,140$ & 4.78 & $12,741,308$ & 181 \\
\hline Southcentral & 11 & $5,136,434$ & 4.82 & $24,764,903$ & 237 \\
\hline Southwestern & 4 & 125,896 & 12.28 & $1,546,249$ & 17 \\
\hline Alaska Peninsula & 0 & 0 & 0 & 0 & 0 \\
\hline Southeastern & 2 & 229,300 & 5.93 & $1,360,201$ & 15 \\
\hline TOTAL & 29 & $10,601,736$ & $\$ 4.94$ & $\$ 52,417,546$ & 590 \\
\hline
\end{tabular}

aFrom 22 returned questionnaires and 12 phone canvass responses.

${ }^{b}$ Values are based on price and cost estimates from 16 producers.

Table 15. Reported rock production and industry employment in Alaska by region, $1999^{a}$

\begin{tabular}{|c|c|c|c|c|c|}
\hline Region & $\begin{array}{c}\text { Companies and } \\
\text { agencies reporting }\end{array}$ & Tons & $\begin{array}{l}\text { Estimated unit } \\
\text { value }(\$ / \text { ton })^{\mathrm{c}}\end{array}$ & $\begin{array}{l}\text { Total } \\
\text { value }\end{array}$ & $\begin{array}{c}\text { Estimated number } \\
\text { of employees }\end{array}$ \\
\hline Northern & 1 & 60,000 & 8.00 & 480,000 & 6 \\
\hline Western & 2 & 6,000 & 10.00 & 60,000 & 10 \\
\hline Eastern Interior & 3 & 112,000 & 9.00 & $1,008,000$ & 22 \\
\hline Southcentral & 3 & 440,000 & 7.60 & $3,344,000$ & 53 \\
\hline Southwestern & 0 & . & -. & .. & $\ldots$ \\
\hline Alaska Peninsula & 0 & $\ldots$ & -. & $\ldots$ & - \\
\hline Southeastern & 3 & $1,717,000$ & 7.64 & $13,117,880$ & 37 \\
\hline TOTAL & 12 & $2,335,000$ & $\$ 7.71$ & $\$ 18,009,880$ & 128 \\
\hline
\end{tabular}

ancludes shot rock, crushed stone, D-1, riprap, and modest quantities of ornamental stone.

${ }^{b}$ Derived from 8 questionnaires, 10 phone canvass responses.

'Unit value based on data supplied by 7 operations. Unit values for different stone products vary widely.

- Not reported. 
Table 16. Red Dog Mine production statistics, 1989-99a

\begin{tabular}{|c|c|c|c|c|c|c|c|c|c|}
\hline & \multirow[b]{2}{*}{$\begin{array}{c}\text { Tons } \\
\text { Milled }\end{array}$} & \multicolumn{3}{|c|}{ Ore Grade } & \multirow{2}{*}{$\begin{array}{l}\text { Total Tons } \\
\text { Concentrate } \\
\text { Produced }^{\mathrm{c}}\end{array}$} & \multirow{2}{*}{$\begin{array}{c}\text { Contained } \\
\text { Tons } \\
\text { Zinc }\end{array}$} & \multirow{2}{*}{$\begin{array}{c}\text { Contained } \\
\text { Tons } \\
\text { Lead }\end{array}$} & \multirow{2}{*}{$\begin{array}{l}\text { Million } \\
\text { Ounces } \\
\text { Silver }^{b}\end{array}$} & \multirow[b]{2}{*}{ Employees } \\
\hline & & $\underset{\%}{\text { Zinc }}$ & $\begin{array}{c}\text { Lead } \\
\%\end{array}$ & $\begin{array}{l}\text { Silver } \\
\text { oz/ton }\end{array}$ & & & & & \\
\hline 1989 & 33,300 & 20.4 & 7.6 & 3.6 & 8,532 & - & .. & -. & 228 \\
\hline 1990 & 996,700 & 26.5 & 8.5 & 3.6 & 443,600 & 191,981 & 31,187 & $\cdots$ & 350 \\
\hline 1991 & $1,599,300$ & 22.5 & 6.6 & 2.8 & 521,400 & 234,510 & 43,815 & - & 331 \\
\hline 1992 & $1,582,000$ & 19.9 & 6.0 & 2.9 & 474,900 & 231,363 & 15,960 & -. & 349 \\
\hline 1993 & $1,874,600$ & 18.4 & 5.7 & 2.8 & 539,800 & 255,149 & 24,788 & - & 376 \\
\hline 1994 & $2,339,500$ & 18.8 & 5.7 & 2.8 & 658,000 & 328,160 & 32,775 & -. & 391 \\
\hline 1995 & $2,485,900$ & 19.0 & 5.8 & 2.8 & 753,600 & 358,676 & 55,715 & 3.615 & 397 \\
\hline 1996 & $2,312,600$ & 18.7 & 5.0 & 2.8 & 765,300 & 357,680 & 65,886 & 4.304 & 417 \\
\hline 1997 & $2,127,000$ & 20.3 & 5.2 & 2.9 & 799,400 & 373,097 & 69,284 & 4.273 & 479 \\
\hline 1998 & $2,752,587$ & 21.4 & 5.2 & 2.7 & $1,015,773$ & 490,461 & 80,193 & 5.202 & 466 \\
\hline 1999 & $3,282,788$ & 21.3 & 5.2 & 2.7 & $1,207,160$ & 574,111 & 97,756 & 6.205 & $539^{d}$ \\
\hline \multicolumn{10}{|c|}{$\begin{array}{l}\text { aRevised slightly from Bundtzen and others (1996) based on ner } \\
\text { b= No data. } \\
\text { bstimate based on grade and tonnage. } \\
\text { 'Totals for years } 1990 \text { through } 1995 \text { include bulk concentrate. } \\
\text { dIncludes support personnel and } 419 \text { mine-mill personnel. } \\
\text { SotrieE: Gary Coulter and Jim Kulas, Cominco Alaska Inc. }\end{array}$} \\
\hline
\end{tabular}

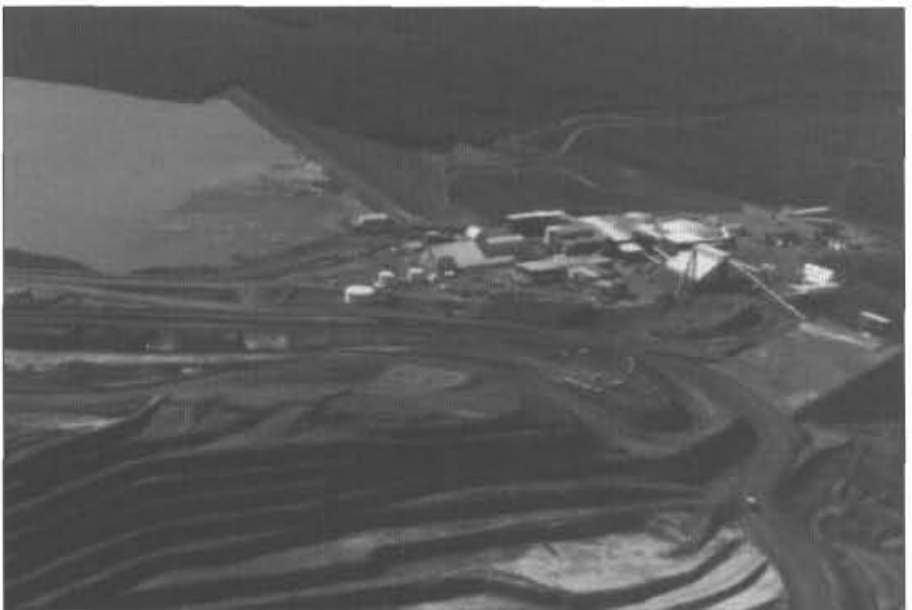

Figure 17. Aerial view of the Main Deposit pit and support facilities at Red Dog Mine. Photo from Cominco webpages (http:/ /www.cominco.com/operations/reddog.htm).

attended by three tugs to lighter the concentrates from the dock, where the water depth is only about 20 feet, to the ships. The possibility of dredging a channel to the dock, and expanding the shiploading capacity of the dock is being investigated.

Placer mines in the Northern region produced only 1,262 ounces in 1999 , mainly from the Wiseman and Chandalar Lake areas.

\section{Industrial Minerals}

About 60,000 tons of rock were used at the Red Dog Mine, but the majority of the sand and gravel, 1.73 million tons, was used at the North Slope oilfields, and for construction projects at the towns in the North Slope Borough.

\section{WESTERN REGION}

\section{Metals}

The underground Nixon Fork gold-copper mine owned by the Real del Monte Mining Corp. was put on care-and-maintenance status on June 4, 1999, but produced about 9,900 ounces of gold and 700 tons of copper prior to closure and during heap rinsing operations throughout the year.

Dakota Mining Corp.'s Illinois Creek gold-silver mine was another casualty of the plummeting gold price, and in 1999 only 6,600 ounces of gold and 62,000 ounces of silver were produced as a result of the rinsing of the ore already on the heap. No new ore was added, but late in the year Viceroy Resources, operator of the Brewery Creek mine in Yukon Territory, opted to examine Illinois Creek for possible future mining. For part of the year the mine was under the stewardship of the State of Alaska Division of Mining, Land \& Water.

About 19 placer mines operated in the Western Region in 1999, producing almost 20,000 ounces of fine gold. Most are small- to medium-sized, though NovaGold Resources Inc. has indicated an interest in resuming mining at the Nome placers, which produced about 25,000 ounces per year for many 
years prior to the 1998 closure.

\section{Industrial Minerals}

There was only minor production of rock from the Sound Quarry at Cape Nome in 1999, but about 718,000 tons of sand and gravel were used for a variety of construction projects throughout the region, mainly on the Seward Peninsula (fig. 18).

\section{EASTERN INTERIOR REGION Metals}

The major mine in the eastern interior region is Fort Knox Gold Mine operated by Fairbanks Gold Mining Inc. for its parent company Kinross Gold Corp. From 30.4 million tons mined, 13.8 million tons were milled in 1999 to produce 351,120 ounces of gold; 4.1 million tons were stored at the stockpile. Gold production from Fort Knox is given in table 17. The mine is a conventional open-pit mine using 23-cubic-yard shovels to load 150-ton trucks for the trip to the in-pit crusher. Crushed ore is conveyed to a storage pile from where it is conveyed to a mill circuit consisting of SAG mills operating in closed circuit with two ball mills and a bank of cyclones (figs. 19, 20). Some raw gold is recovered in various gravity traps, but the bulk is extracted in a cyanide circuit. Gold recovery is approximately 90 percent.
A 1999 report commissioned by the Fairbanks North Star Borough showed that Fort Knox Mine creates 260 direct, and 312 indirect, jobs in Fairbanks. The company spends over \$35 million annually on local goods and services, has an annual \$107 million impact on the local economy, and pays the borough $\$ 4.4$ annually in real estate taxes and other revenue.

About 56 placer gold mines operated in the eastern interior in 1999 , and they produced about 41,123 ounces of gold. All but three would be considered small- to mediumsized, and table 12 shows the distribution by mining district. Many long-time miners are taking a wait-and-see approach to the historic low gold prices that prevailed through much of 1999, and several have elected not to mine in 2000 .

\section{COAL}

Usibelli Coal Mine at Healy produced 1,560,000 short tons in 1999, mainly from the Poker Flats pit that has been the mainstay of production for many years. Some coal was gleaned from the road cuts that are being prepared to access the Two Bull Ridge lease on the east side of the river

Figure 18. Loading rock from the Cape Nome quarry onto a barge bound for Dillingham. Photo provided by Tom Sparks, Bering Straits Native Corp.

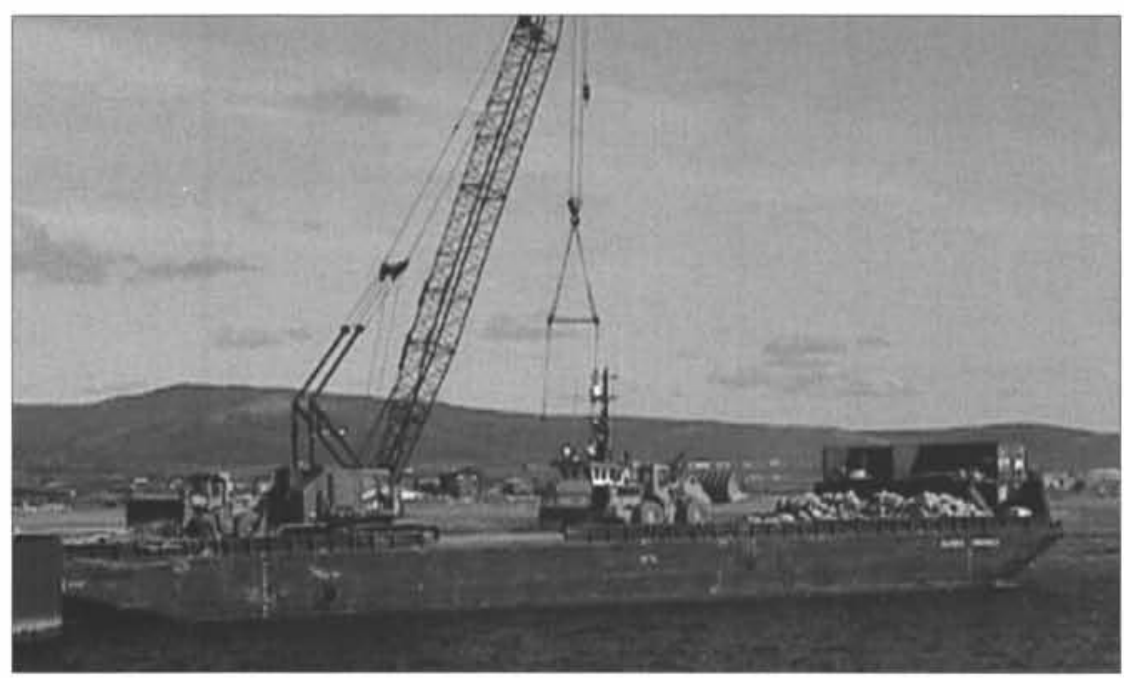

Table 17. Fort Knox Gold Mine production statistics, 1996-99

\begin{tabular}{ccccc}
\hline & $\begin{array}{c}\text { Tons } \\
\text { Mined }\end{array}$ & $\begin{array}{c}\text { Tons } \\
\text { Milled }\end{array}$ & $\begin{array}{c}\text { Ounces } \\
\text { Produced }\end{array}$ & Employment \\
1996 & $16,684,000$ & 769,700 & 16,085 & 243 \\
1997 & $32,380,000$ & $12,163,151$ & 366,223 & 249 \\
1998 & $33,294,000$ & $13,741,610$ & 365,320 & 245 \\
1999 & $30,350,000$ & $13,819,010$ & 351,120 & 253 \\
\hline
\end{tabular}


from the Poker Flats lease. About 563,000 short tons were exported to the KEPCO facility in Korea via the Alaska Railroad and the coal-loading facility at the port of Seward.

Some of the coal in the lowest seam on the Two Bull Ridge is "shaley" and would be ideal for the new Clean Coal Plant at the mine mouth, but disagreements between the parties involved in the construction of the plant have cast a cloud on its future. The plant performed at more than 95 percent availability during a 90 -day test-run.

\section{Industrial Minerals}

Most of the rock, sand and gravel in this region was used in road construction projects, particularly between Delta Junction and Tok, and east of Tok to the Canadian border. About 2.4 million tons of sand and gravel and 112,000 tons of rock were used in the work.

\section{SOUTHCENTRAL REGION \\ Metals}

Eight small placer mines produced a reported 305 ounces of gold in the southcentral region in 1999.

\section{Industrial Minerals}

About 5.1 million tons of sand and gravel and 440,000 tons of rock were used in road construction in the southcentral region in 1999. Much of the sand and gravel was derived from pits in the Palmer and Wasilla areas and hauled by the Alaska Railroad to the construction sites. The major road construction projects in the region were at miles 55-61 of the Glen Highway, miles 35-37 of the Parks Highway, miles $37-45$ of the Sterling Highway, and widening of the railroad tunnel for road access to the port of Whittier on the Gulf of Alaska.

\section{SOUTHWESTERN REGION}

\section{Metals}

Eight placer gold mines produced 7,577 ounces of gold in 1999.

\section{Industrial Minerals}

About 126,000 tons of sand and gravel were used for construction in the Platinum and Goodnews areas.
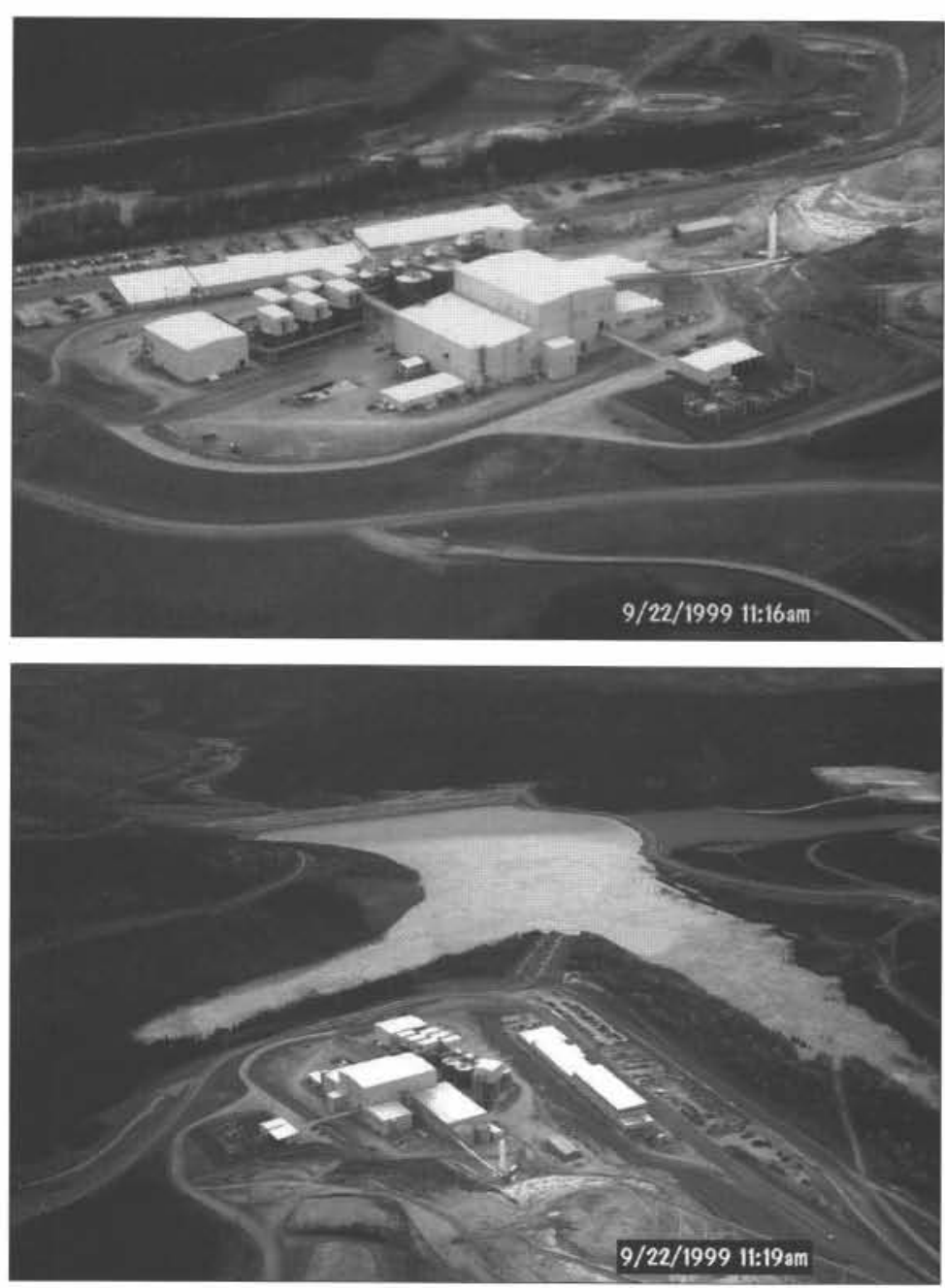

Figure 19. View of ore processing facilities at Kinross Gold Corp.'s Fort Knox Mine. Conveyor belt at right side of photo leads from gyratory crusher and coarse ore stockpile to mill facilities. Tall buildings in center of photo contain mill facilities. Leach tanks and carbon-in-pulp tanks are behind the mill facilities. Office, warehouse, and maintenance shop facilities are located within the long rectangular building complex behind the tanks. Photo by Ryan Hull, DMLW.

Figure 20. View of office, shop, and milling complex at Fort Knox Mine, as described in figure 19, with tailings pond and impoundment dam in background. The tailings impoundment is a zero-discharge system and includes seepage control facilities and monitoring wells. Photo by Ryan Hull, DMLW. 


\section{SOUTHEASTERN REGION \\ Metals}

Greens Creek Mine (70.27 percent Kennecott Minerals Company, 29.73 percent Hecla Mining Company) produced a record amount of zinc and lead concentrate in 1999 (table 18) containing record amounts of gold and silver. From the 578,358 tons milled, the mine produced 68,527 tons of zinc, 25,503 tons of lead, $10,261,835$ ounces of silver and 80,060 ounces of gold. The mine is about 20 miles west of Juneau, and employs 275 permanent workers.

\section{Industrial Minerals}

About 229,000 tons of sand and gravel were used for road and other construction projects throughout the region, and about 1.7 million tons of crushed rock was used by the U.S. Forest Service to maintain the logging roads in the Tongass National Forest.

Table 18. Greens Creek Mine production statistics, 1989-99

\begin{tabular}{|c|c|c|c|c|c|c|c|c|}
\hline & $\begin{array}{c}\text { Tons } \\
\text { Milled }\end{array}$ & $\begin{array}{c}\text { Tons } \\
\text { Concentrate }\end{array}$ & $\begin{array}{c}\text { Contained } \\
\text { Tons } \\
\text { Zinc }\end{array}$ & $\begin{array}{c}\text { Contained } \\
\text { Tons } \\
\text { Lead }\end{array}$ & $\begin{array}{c}\text { Contained } \\
\text { Ounces } \\
\text { Silver }\end{array}$ & $\begin{array}{c}\text { Contained } \\
\text { Ounces } \\
\text { Gold }\end{array}$ & $\begin{array}{c}\text { Contained } \\
\text { Tons } \\
\text { Copper }\end{array}$ & Employees \\
\hline 1989 & 264,600 & - & 18,007 & 9,585 & $5,166,591$ & 23,530 & $\cdots$ & 235 \\
\hline 1990 & 382,574 & $\cdots$ & 37,000 & 16,728 & $7,636,501$ & 38,103 & $\cdots$ & 265 \\
\hline 1991 & 380,000 & $\ldots$ & 41,850 & 16,900 & $7,600,000$ & 37,000 & . & 238 \\
\hline 1992 & 365,000 & 113,827 & 40,500 & 16,500 & $7,100,000$ & 32,400 & $\cdots$ & 217 \\
\hline $1993^{a}$ & 77,780 & . & 9,500 & 3,515 & $1,721,878$ & 7,350 & $\cdots$ & 217 \\
\hline 1994 & . & $\cdots$ & - & - & $\cdots$ & $\cdots$ & $\cdots$ & - \\
\hline 1995 & - & - & - & - & - & - & - & - \\
\hline $1996^{\mathrm{a}}$ & 135,000 & 43,000 & 9,100 & 4,200 & $2,476,000$ & 7,480 & 193 & 265 \\
\hline 1997 & 493,000 & $\ldots$ & 46,000 & 19,000 & $9,700,000$ & 56,000 & 1,300 & 275 \\
\hline 1998 & 540,000 & $\cdots$ & 58,900 & 22,700 & $9,500,000$ & 60,572 & 1,300 & 275 \\
\hline 1999 & 578,358 & $\ldots$ & 68,527 & 25,503 & $10,261,835$ & 80,060 & 1,400 & 275 \\
\hline
\end{tabular}

\section{DRILLING}

Tables 19 and 20 summarize drilling activity in the state during 1999 by region and type of drilling. Many companies had significant drilling programs (table 21). Drilling totals continue the decline begun in 1998 due to slumping metal prices and difficulty in raising venture capital. In particular, placer drilling was down sharply, reflecting the overall low amount of placer mining activity. The increase in the reverse-circulation drilling total from 1998 reflects more drilling at road-accessible properties, particularly in the Fairbanks and Nome areas (fig. 21). There was also an increase in underground exploration drilling due to the Pogo Project (fig. 22).

Table 19. Drilling footage by region in Alaska, 1999

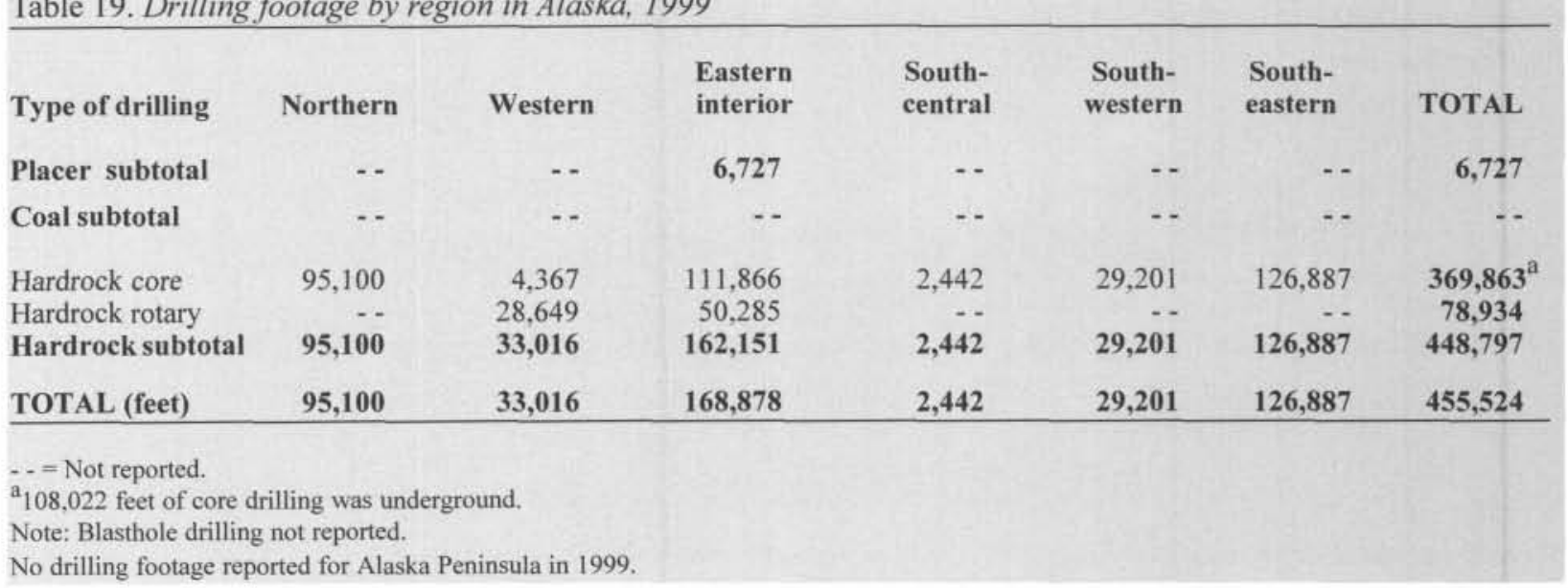


Table 20. Drilling footage reported in Alaska, 1982-99

\begin{tabular}{|c|c|c|c|c|c|c|c|c|}
\hline Year & $\begin{array}{c}\text { Placer } \\
\text { Exploration }\end{array}$ & $\begin{array}{l}\text { Placer } \\
\text { Thawing }\end{array}$ & $\begin{array}{c}\text { TOTAL } \\
\text { PLACER }\end{array}$ & $\begin{array}{l}\text { TOTAL } \\
\text { COAL }\end{array}$ & $\begin{array}{c}\text { TOTAL } \\
\text { HARDROCK }\end{array}$ & $\begin{array}{c}\text { Hardrock } \\
\text { Core }^{a}\end{array}$ & $\begin{array}{l}\text { Hardrock } \\
\text { Rotary }\end{array}$ & $\begin{array}{c}\text { TOTAL } \\
\text { FEET }\end{array}$ \\
\hline 1982 & 30,000 & 94,000 & 124,000 & 80,000 & 200,000 & - & - & 404,000 \\
\hline 1983 & 23,000 & 30,000 & 53,000 & 12,000 & 180,500 & - & $\cdots$ & 245,500 \\
\hline 1984 & 31,000 & 98,000 & 129,000 & 25,700 & 176,000 & . & $\cdots$ & 330,700 \\
\hline 1985 & 46,000 & 34,000 & 80,000 & 8,700 & 131,700 & -. & -. & 220,400 \\
\hline 1986 & 32,400 & 227,000 & 259,400 & 28,800 & 50,200 & ․ & . & 338,400 \\
\hline 1987 & 50,250 & 130,000 & 180,250 & 19,900 & 115,100 & 95,600 & 19,500 & 315,250 \\
\hline 1988 & 152,000 & 300,000 & 452,000 & 26,150 & 353,860 & 223,630 & 130,230 & 832,010 \\
\hline 1989 & 97,250 & 210,000 & 307,250 & 38,670 & 332,230 & 242,440 & 89,790 & 678,150 \\
\hline 1990 & 78,930 & 105,000 & 183,930 & 18,195 & 760,955 & 648,600 & 112,355 & 963,080 \\
\hline 1991 & 51,247 & 130,000 & 181,247 & 16,894 & 316,655 & 205,805 & 110,850 & 514,796 \\
\hline 1992 & 6,740 & 65,000 & 71,740 & 12,875 & 359,834 & 211,812 & 148,022 & 444,449 \\
\hline 1993 & 25,216 & . & 25,216 & . & 252,315 & 124,325 & 127,990 & 277,531 \\
\hline 1994 & 21,000 & .. & 21,000 & 8,168 & 438,710 & 347,018 & 91,692 & 467,878 \\
\hline 1995 & 27,570 & - & 27,570 & - & 415,485 & 363,690 & 51,795 & 443,055 \\
\hline 1996 & 61,780 & - & 61,780 & 8,500 & 658,857 & 524,330 & 134,527 & 729,137 \\
\hline 1997 & 38,980 & $\cdots$ & 38,980 & 13,998 & 704,510 & 523,676 & 180,834 & 757,488 \\
\hline 1998 & 33,250 & - & 33,250 & 2,300 & 549,618 & 505,408 & 45,670 & 585,168 \\
\hline 1999 & 6,727 & - & 6,727 & -. & 448,797 & $369,863^{b}$ & 78,934 & 455,524 \\
\hline
\end{tabular}

${ }^{a}$ Core and rotary drilling not differentiated prior to 1987.

${ }^{b} 108,022$ feet of core drilling was underground.

.. = Not reported.

Note: Blasthole drilling not reported. Approximately 4,920,000 feet in 1999. 5,000 feet of rotary drilling for sand and gravel not included in totals.

\section{Table 21. Companies reporting significant drilling programs in} Alaska, 1999

Alaska Placer Development

Atna Resources Ltd.

Camnor Resources Ltd.

Consolidated Aston Resources Ltd.

Cominco Alaska Inc.

Hecla Mining Co.

Kennecott Exploration Co.

Kennecott Greens Creek

Mining Co.

Kinross Gold Corp.

Newmont Exploration Ltd.

NovaGold Resources Inc.

Figure 21 (top). Bryan Outwater, Bering Straits Native Corp. shareholder, works on TJ Enterprises reverse-circulation drill rig drilling for gold mineralization at NovaGold Resources' Anvil Creek properties near Nome. Drilling performed by a 5.5-inch-diameter hammer and tri-cone drill bit using a 900 CFM capacity compressor: Photo provided by Tom Sparks, Bering Straits Native Corp.

Figure 22 (bottom). Underground drilling station in Pogo decline. Drilling by Major Alaska Drilling Inc, using JKS Boyles B15 drill rig. Photo provided by Teck Resources Inc.
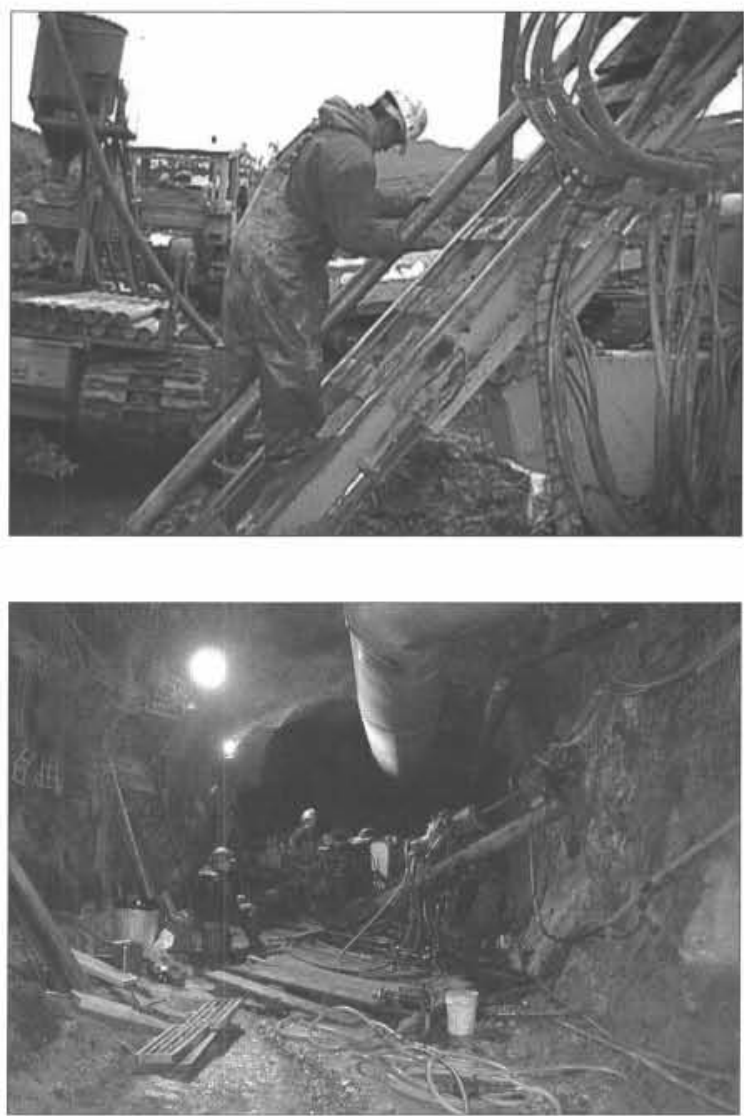


\section{GOVERNMENT ACTIONS}

Table 22 shows the revenues to the state and to several municipalities from the mining industry. The increase in state claim rentals reflects both the maturing of several claim blocks and the consequent doubling of the rental payments, as well as the cost-of-living increase built into the statute requiring the rental. The Mining License Tax will also increase as the 3.5-year exemption is exceeded by operating mines.

The DGGS Airborne Geophysical/Geological Mineral Inventory project was first funded in FY93 as a multi-year investment to expand the knowledge base of Alaska's mineral resources and catalyze private-sector mineral development. The first mineral district surveys were flown in
1993. As of December 1999, 4.62 million acres of geophysical surveys in 14 areas across Alaska had been released (table 23).

In 1999 the State Division of Geological \& Geophysical Surveys (DGGS) contracted for an airborne geophysical survey of about 1,000 square miles northwest of the Pogo deposit, and included radiometrics with the standard electromagnetic and magnetic components. The results are expected by early 2000 . Another magnetic/electromagnetic survey of parts of Prince of Wales Island in southeastern Alaska was completed in 1999 with funding from the U.S. Bureau of Land Management, the Ketchikan Gateway Borough, the cities of Coffman Cove and Helm Bay and the

Table 22. Revenues paid to the State of Alaska and municipalities by Alaska's mineral industry, 1994-99a

\begin{tabular}{|c|c|c|c|c|c|c|}
\hline & 1994 & 1995 & 1996 & 1997 & 1998 & 1999 \\
\hline \multicolumn{7}{|l|}{ State mineral rents and royalties } \\
\hline State claim rentals ${ }^{b}$ & 805,291 & $\$ 703,508$ & $\$ 917,970$ & $\$ 1,036,782$ & $\$ 1,170,812$ & \$ $1,982,453$ \\
\hline Production royalties & 11,003 & 13,661 & 20,002 & 8,930 & 9,489 & 14,214 \\
\hline Annual labor & 42,682 & 32,195 & 55,195 & 80,795 & 118,020 & 90,720 \\
\hline Subtotal & 858,976 & 749,364 & 993,166 & $1,126,507$ & $1,298,321$ & $2,087,387$ \\
\hline \multicolumn{7}{|l|}{ State coal rents and royalties } \\
\hline Rents & 199,124 & 172,026 & 188,210 & 173,773 & 331,716 & 205,983 \\
\hline Royalties & $1,391,614$ & $1,866,954$ & 996,408 & $1,342,077$ & $19,378,995$ & $2,615,858$ \\
\hline Bonus & 0 & 0 & 0 & 0 & 0 & 0 \\
\hline Offshore Prospecting Permits & 3,221 & 4,182 & 0 & 0 & 0 & 0 \\
\hline Subtotal & $1,593,959$ & $2,043,162$ & $1,184,619$ & $1,515,851$ & $2,269,711$ & $2,821,841$ \\
\hline \multicolumn{7}{|l|}{ State material sales } \\
\hline Mental Health & 0 & 10,108 & 63,324 & 57,620 & 40,269 & 32,407 \\
\hline Division of Land & 218,876 & 351,094 & 699,845 & 278,913 & $1,043,602$ & 586,550 \\
\hline SPCO & 128,062 & 115,745 & 26,673 & 27,579 & 28,491 & 28,941 \\
\hline Subtotal & 346,938 & 476,947 & 789,842 & 364,111 & $1,112,362$ & 647,898 \\
\hline \multicolumn{7}{|l|}{ State mining miscellaneous fees } \\
\hline Filing Fees & 1,290 & 2,074 & 1,500 & 4,187 & -251 & 4,288 \\
\hline Penalty Fees & 0 & 1,000 & 0 & 0 & 0 & 8,000 \\
\hline Explore incentive app filing fee & 0 & 0 & 0 & 0 & 2,000 & 3,000 \\
\hline Bond pool payment & 63,251 & 60,619 & 87,411 & 91,666 & 79,929 & 70,692 \\
\hline Surface coal mining app fee & 1,350 & 7,530 & 36,728 & $-16,100$ & 6,890 & 2,500 \\
\hline APMA mining fees & 14,253 & 19,950 & 21,950 & 22,454 & 18,975 & 19,288 \\
\hline Subtotal & 80,144 & 91,173 & 147,589 & 102,207 & 107,543 & 107,767 \\
\hline Mining license $e^{c}$ & 481,907 & 484,035 & 481,000 & $1,900,000$ & $2,037,226$ & $2,400,000$ \\
\hline $\begin{array}{l}\text { State total } \\
\text { Payments to }\end{array}$ & $3,361,924$ & $3,844,680$ & $3,596,215$ & $5,008,676$ & $6,825,163$ & $8,064,893$ \\
\hline $\begin{array}{l}\text { Payments to } \\
\text { Municipalities }\end{array}$ & N/A & N/A & N/A & $8,386,000$ & $7,934,000$ & $8,818,819$ \\
\hline TOTAL & $\$ 2,880,017$ & $\$ 3,360,645$ & $\$ 3,115,215$ & $\$ 13,394,676$ & $\$ 14,759,163$ & $\$ 16,883,712$ \\
\hline
\end{tabular}

aDoes not include state corporate income taxes, which were not released for this study.

bIncludes upland lease and offshore lease rentals.

'Includes metals, coal, and material.

$\mathrm{N} / \mathrm{A}=$ not available.

.. = not reported.

SOURCE: Municipalities, companies, and DNR Financial Services Section. 
Table 23. Airborne geophysical survey work released by DGGS as of December 1999

Nome District western core area

Nyac District core area

Circle District core area

Valdez Creek District

Fairbanks District

Richardson District

Rampart/Manley-Tofty

Upper Chulitna District

Petersville-Collinsville District

Iron Creek District

Ruby District

Fortymile District

Livengood District

229 sq. miles

SalchaRiver/North Pogo

1,032 sq. miles

7,235 sq. miles
Airborne geophysical/ground-truth geological mapping

Airborne aeromagnetic mapping

Airborne geophysical mapping/ground-truth geologic map

Airborne geophysical mapping

Airborne geophysical mapping/ground-truth geologic map Airborne geophysical mapping

Airborne geophysical mapping/ground-truth geologic map Airborne geophysical mapping/ground-truth geologic map Airborne geophysical mapping/ground-truth geologic map Airborne geophysical mapping/ground-truth geologic map Airborne geophysical mapping/ground-truth geologic map Airborne geophysical mapping/ground-truth geologic map (ground-truth began FY00; 3-year project)

Airborne geophysical mapping

Airborne geophysical mapping

(ground-truth begins in FY01; 3-year project)

$1.2 \%$ of Alaska's total area

Note: Surveys listed above are complete except where noted. Additional areas will be scheduled for surveying at later dates contingent on future funding.

Alaska State Mental Health Land Office, with additional survey data from previous years provided by Sealaska Native Corp.

A team of geologists from DGGS began bedrock and surficial geologic mapping in the Fortymile area during 1999 (fig. 23). This area had been the subject of a 1998 airborne survey. A preliminary geologic map of the Eagle A-2 Quadrangle will be released by mid 2000. Field mapping will continue in 2000. A team of scientists from the U.S. Geological Survey and the Alaska Division of Mining, Land \& Water conducted baseline water geochemical sampling and geological mapping program in the Fortymile and Goodpaster River drainages east of Fairbanks.

DGGS and USGS geologists also mapped a portion of the Talkeetna Mountains Quadrangle within the DGGS Iron Creek geophysical survey area. A preliminary geologic map and rock sample analytical results are expected to be released by mid 2000 .

The U.S. Department of the Interior's Minerals Management Service distributed \$4.16 million to Alaska in 1999 as part of the state's share of revenue collected for minerals production on federal lands within the state, plus offshore tracts adjacent to Alaska's shore. The money, $\$ 245,935$ of which came from offshore tracts, represents the state's share of bonuses, rents and royalties. A total of $\$ 541.4$ million was paid to 36 states in 1999 under the program. Amounts vary from year to year according to production and market prices. Alaska was tenth on the payout list, far behind Wyoming, which ranked first with \$241 million.

Red Dog Operations received the Exporter of the Year Award for 1999 from Alaskan governor Tony Knowles. The award acknowledged the successful completion of Red Dog's expansion program and the mine's ability to deliver

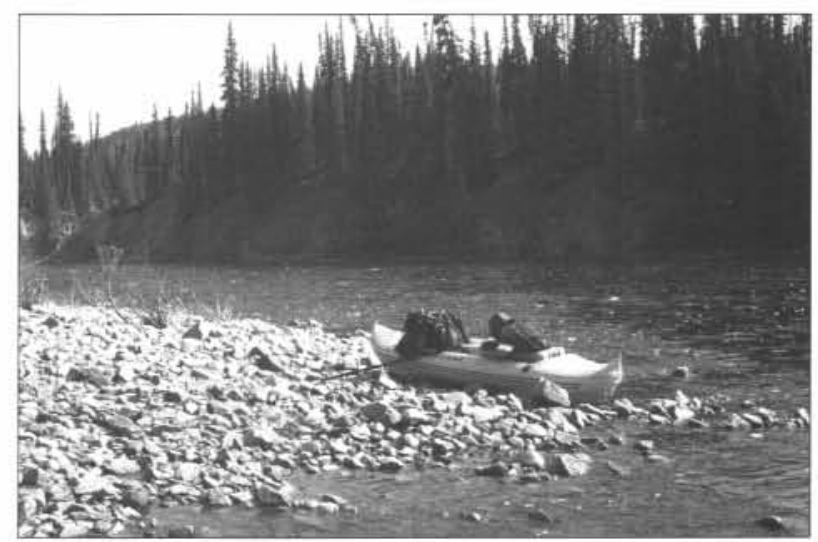

Figure 23. Inflatable kayak beached on gravel bar along the Dennison Fork of the Fortymile River. One of many transportation methods used by DGGS to map the Fortymile area. Photo by David Szumigala. 
higher volumes of ore concentrates to offshore markets.

The 1999 Alaska reclamation award was given to Wayne Gibson for his reclamation efforts on Golden Creek in the Melozitna mining district (figs. 24, 25).

The Delta Mine Training Center (DMTC) was established in Delta Junction, Alaska in early 1999. DMTC was formed to inform community members in the region about the mineral industry and to prepare workers to enter jobs in mining and exploration. The DMTC is a consortium of the following organizations:

- Alaska Miners Association

- University of Alaska Anchorage - Mining and Petroleum Training Service (MAPTS)

- University of Alaska Fairbanks - Tanana Valley Campus

- Tanana Chiefs Conference, Inc.

- Delta/Greely School District

DMTC is now training workers for employment in underground mines. In addition to a 7-week underground miner course, DMTC also provides courses in basic geology, prospecting, and basic field exploration techniques. DMTC plans to develop a training adit for instruction use and add more courses to its schedule.

The Alaska Department of Natural Resources (DNR), Division of Mining, Land \& Water (DMLW) offered 28 offshore mining lease tracts near Nome for competitive bid. DMLW received 76 bids from 15 bidders totaling $\$ 190,000$ for 12,292 acres. Successful bidders received an offshore mining lease that grants exclusive right to locatable minerals in the offshore area on state-owned tide and submerged land. Lease tracts ranged in size from 100 to 1,440 acres and leases were issued for a term of ten years subject to renewal dependent on obtaining all necessary permits from regulating agencies having jurisdiction.

The Land Records Information Section (LRIS) of DNR is in the process of streamlining access to mining claim information. LRIS is building a WorldWideWeb site for on-line status plats at http://www.dnr.state.ak.us/ landrecords. A status plat is a state document that describes the location of state land, the classification of the land, and assignments of state interest in land. A status plat is the graphic land record of the department. The township (36 square miles) is the standard format for a status plat. If there is too much activity to map at this scale, cartographers will create supplemental plats. The most complex townships in the state can have over 100 supplementals. Simple townships with limited activity can have a single plat. DNR maintains about 17,000 plats. LRIS is also working on streamlining the processing of mining claims. Eventually the DNR system will process and load mining claims from data inputted into the computer at State Recorder's offices. The system will also be built to automate the notation of status plats with new mining claims.

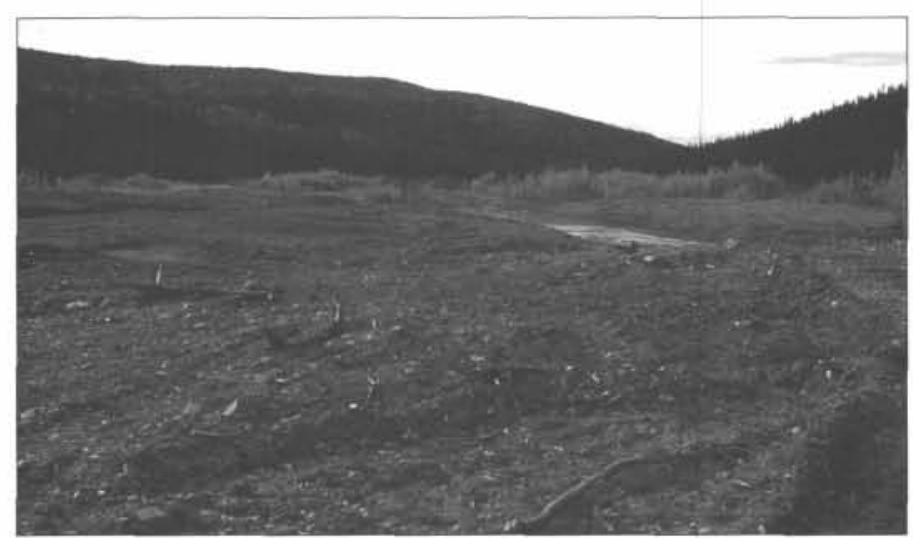

Figures 24 \& 25. Reclamation of Golden Creek in the Melozitna mining district by Wayne Gibson. Photos by Ryan Hull, DMLW.

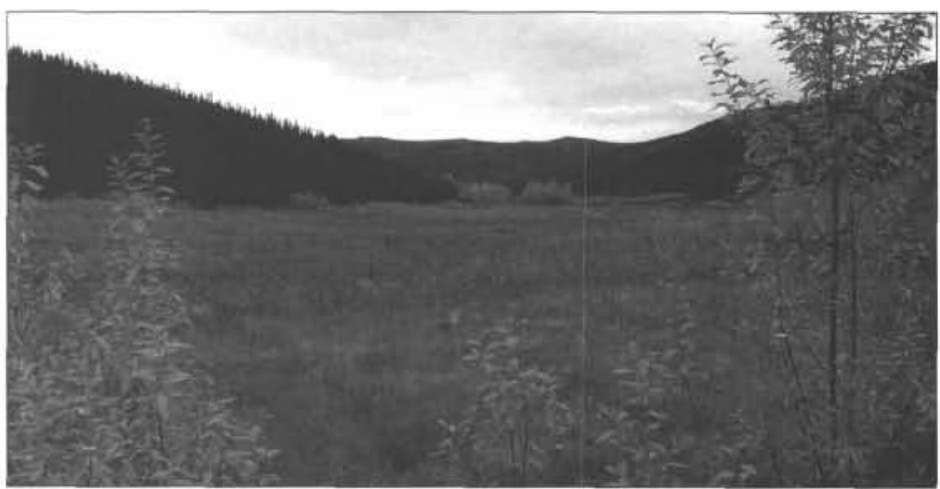




\section{APPENDIX A}

New claims staked in Alaska 1995-1999

\begin{tabular}{|c|c|c|c|c|c|c|c|c|c|c|c|}
\hline \multirow{2}{*}{$\begin{array}{c}\text { Quad } \\
\text { no. }\end{array}$} & \multirow{2}{*}{$\begin{array}{l}\text { Quadrangle } \\
\text { name }\end{array}$} & \multicolumn{5}{|c|}{ New federal mining claims } & \multicolumn{5}{|c|}{ New state mining claims } \\
\hline & & 1995 & 1996 & 1997 & 1998 & 1999 & 1995 & 1996 & 1997 & 1998 & 1999 \\
\hline 17 & Point Hope & 0 & 0 & 0 & 0 & 0 & 0 & 43 & 0 & 0 & 0 \\
\hline 18 & De Long Mountains & 0 & 0 & 0 & 0 & 0 & 28 & 0 & 0 & 0 & $6,054^{\mathrm{a}}$ \\
\hline 20 & Howard Pass & 0 & 0 & 0 & 0 & 0 & 0 & 0 & 0 & 0 & 183 \\
\hline 23 & Philip Smith Mountains & 0 & 0 & 0 & 0 & 0 & 0 & 0 & 0 & 0 & 0 \\
\hline 26 & Noatak & 0 & 0 & 0 & 0 & 0 & 61 & 634 & 96 & 0 & 514 \\
\hline 27 & Baird Mountains & 1 & 0 & 1 & 0 & 0 & 18 & 1 & 0 & 1 & 65 \\
\hline 28 & Ambler River & 0 & 0 & 0 & 0 & 0 & 95 & 0 & 1,333 & 6 & 0 \\
\hline 29 & Survey Pass & 0 & 0 & 0 & 0 & 0 & 0 & 0 & 722 & 0 & 0 \\
\hline 30 & Wiseman & 20 & 0 & 47 & 90 & 13 & 34 & 6 & 44 & 108 & 85 \\
\hline 31 & Chandalar & 12 & 3 & 17 & 1 & 13 & 502 & 118 & 75 & 37 & 0 \\
\hline 32 & Christian & 0 & 0 & 0 & 0 & 0 & 0 & 0 & 0 & 0 & 0 \\
\hline 35 & Kotzebue & 0 & 0 & 0 & 0 & 0 & 4 & 0 & 28 & 0 & 0 \\
\hline 36 & Selawik & 0 & 0 & 0 & 0 & 0 & 0 & 0 & 0 & 0 & 2 \\
\hline 37 & Shungnak & 0 & 0 & 0 & 0 & 0 & 0 & 0 & 0 & 0 & 0 \\
\hline 38 & Hughes & 0 & 0 & 0 & 0 & 0 & 0 & 0 & 72 & 1 & 1 \\
\hline 39 & Bettles & 7 & 0 & 56 & 28 & 12 & 4 & 0 & 0 & 2 & 1 \\
\hline 43 & Teller & 0 & 0 & 0 & 0 & 0 & 42 & 0 & 0 & 0 & 25 \\
\hline 44 & Bendeleben & 0 & 0 & 0 & 0 & 0 & 31 & 55 & 67 & 45 & 60 \\
\hline 45 & Candle & 0 & 0 & 0 & 0 & 0 & 21 & 16 & 201 & 10 & 55 \\
\hline 47 & Melozitna & 0 & 0 & 0 & 0 & 0 & 4 & 4 & 0 & 0 & 0 \\
\hline 48 & Tanana & 0 & 0 & 0 & 0 & 0 & 53 & 76 & 99 & 87 & 24 \\
\hline 49 & Livengood & 0 & 0 & 1 & 0 & 0 & 545 & 1,838 & 352 & 32 & 38 \\
\hline 50 & Circle & 0 & 0 & 0 & 0 & 0 & 413 & 100 & 658 & 698 & 410 \\
\hline 51 & Charley River & 0 & 0 & 0 & 0 & 0 & 0 & 0 & 0 & 0 & 0 \\
\hline 52 & Nome & 0 & 0 & 0 & 0 & 0 & 168 & 195 & 78 & 42 & 0 \\
\hline 53 & Solomon & 0 & 0 & 0 & 0 & 0 & 39 & 31 & 29 & 10 & 2 \\
\hline 54 & Norton Bay & 0 & 0 & 0 & 0 & 0 & 25 & 0 & 0 & 0 & 0 \\
\hline 55 & Nulato & 0 & 0 & 0 & 0 & 0 & 0 & 0 & 0 & 0 & 80 \\
\hline 56 & Ruby & 0 & 0 & 0 & 0 & 0 & 12 & 405 & 200 & 718 & 90 \\
\hline 57 & Kantishna River & 0 & 0 & 1 & 0 & 0 & 14 & 0 & 0 & 0 & 8 \\
\hline 58 & Fairbanks & 0 & 0 & 0 & 0 & 0 & 364 & 360 & 546 & 111 & 22 \\
\hline 59 & Big Delta & 0 & 0 & 0 & 0 & 0 & 421 & 637 & 1,010 & 4,595 & $3,084^{b}$ \\
\hline 60 & Eagle & 0 & 0 & 0 & 0 & 0 & 116 & 122 & 171 & 722 & 371 \\
\hline 64 & Ophir & 0 & 0 & 0 & 0 & 0 & 8 & 13 & 47 & 3 & 11 \\
\hline 65 & Medfra & 0 & 0 & 0 & 0 & 0 & 0 & 0 & 128 & 46 & 38 \\
\hline 66 & Mt. McKinley & 0 & 0 & 0 & 0 & 0 & 0 & 0 & 0 & 0 & 0 \\
\hline 67 & Healy & 0 & 0 & 0 & 0 & 0 & 335 & 80 & 388 & 641 & 66 \\
\hline 68 & Mt. Hayes & 171 & 124 & 772 & 2 & 0 & 858 & 622 & 1,185 & 975 & 483 \\
\hline 69 & Tanacross & 0 & 0 & 0 & 0 & 0 & 69 & 236 & 112 & 748 & 307 \\
\hline 72 & Holy Cross & 0 & 0 & 0 & 0 & 0 & 0 & 0 & 0 & 0 & 0 \\
\hline 73 & Iditarod & 0 & 70 & 0 & 0 & 0 & 223 & 414 & 296 & 94 & 0 \\
\hline 74 & McGrath & 0 & 0 & 0 & 0 & 0 & 0 & 0 & 0 & 0 & 32 \\
\hline 75 & Talkeetna & 3 & 0 & 0 & 0 & 0 & 48 & 129 & 117 & 111 & 73 \\
\hline 76 & Talkeetna Mountains & 0 & 0 & 4 & 0 & 0 & 48 & 234 & 50 & 131 & 3 \\
\hline 77 & Gulkana & 0 & 0 & 0 & 0 & 0 & 0 & 0 & 192 & 7 & 247 \\
\hline 78 & Nabesna & 0 & 0 & 0 & 0 & 0 & 0 & 0 & 2 & 0 & 5 \\
\hline 81 & Russian Mission & 0 & 0 & 0 & 0 & 0 & 0 & 0 & 0 & 0 & 0 \\
\hline 82 & Sleetmute & 0 & 0 & 0 & 0 & 0 & 22 & 0 & 0 & 0 & 80 \\
\hline 83 & Lime Hills & 0 & 0 & 0 & 0 & 0 & 8 & 2 & 238 & 26 & 12 \\
\hline 84 & Tyonek & 0 & 0 & 0 & 0 & 0 & 8 & 0 & 10 & 34 & 69 \\
\hline 85 & Anchorage & 0 & 0 & 0 & 0 & 0 & 79 & 18 & 97 & 88 & 40 \\
\hline 86 & Valdez & 0 & 0 & 0 & 0 & 0 & 20 & 11 & 8 & 0 & 0 \\
\hline 87 & McCarthy & 0 & 0 & 0 & 0 & 0 & 0 & 0 & 0 & 52 & 0 \\
\hline 91 & Bethel & 0 & 0 & 0 & 0 & 0 & 0 & 0 & 98 & 0 & 0 \\
\hline
\end{tabular}




\begin{tabular}{|c|c|c|c|c|c|c|c|c|c|c|c|}
\hline \multirow{2}{*}{$\begin{array}{c}\text { Quad } \\
\text { no. }\end{array}$} & \multirow{2}{*}{$\begin{array}{l}\text { Quadrangle } \\
\text { name }\end{array}$} & \multicolumn{5}{|c|}{ New federal mining claims } & \multicolumn{5}{|c|}{ New state mining claims } \\
\hline & & 1995 & 1996 & 1997 & 1998 & 1999 & 1995 & 1996 & 1997 & 1998 & 1999 \\
\hline 92 & Taylor Mountains & 0 & 0 & 0 & 0 & 0 & 5 & 0 & 142 & 37 & 0 \\
\hline 93 & Lake Clark & 0 & 0 & 0 & 0 & 0 & 0 & 0 & 0 & 0 & 0 \\
\hline 94 & Kenai & 0 & 0 & 0 & 0 & 0 & 0 & 0 & 0 & 0 & 0 \\
\hline 95 & Seward & 58 & 0 & 108 & 44 & 24 & 21 & 23 & 26 & 22 & 38 \\
\hline 96 & Cordova & 0 & 0 & 1 & 0 & 0 & 0 & 0 & 0 & 3 & 0 \\
\hline 97 & Bering Glacier & 0 & 0 & 0 & 0 & 0 & 0 & 2 & 3 & 2 & 0 \\
\hline 102 & Dillingham & 0 & 0 & 0 & 0 & 0 & 4 & 7 & 32 & 0 & 0 \\
\hline 103 & Iliamna & 0 & 0 & 0 & 0 & 0 & 1 & 1 & 325 & 1 & 0 \\
\hline 104 & Seldovia & 0 & 0 & 0 & 0 & 0 & 0 & 0 & 0 & 0 & 0 \\
\hline 107 & Icy Bay & 0 & 0 & 0 & 0 & 0 & 0 & 0 & 3 & 0 & 0 \\
\hline 108 & Yakutat & 0 & 0 & 0 & 0 & 0 & 0 & 0 & 0 & 0 & 0 \\
\hline 109 & Skagway & 2 & 0 & 4 & 0 & 1 & 36 & 8 & 5 & 1 & 38 \\
\hline 111 & Mt. Fairweather & 0 & 0 & 0 & 0 & 0 & 0 & 0 & 0 & 0 & 0 \\
\hline 112 & Juneau & 63 & 199 & 263 & 52 & 10 & 10 & 20 & 2 & 0 & 2 \\
\hline 114 & Sitka & 2 & 0 & 7 & 10 & 0 & 2 & 0 & 0 & 3 & 0 \\
\hline 115 & Sumdum & 0 & 0 & 0 & 0 & 0 & 0 & 0 & 0 & 0 & 0 \\
\hline 116 & Port Alexander & 0 & 0 & 0 & 0 & 0 & 0 & 0 & 0 & 0 & 0 \\
\hline 117 & Petersburg & 23 & 267 & 485 & 183 & 98 & 0 & 0 & 0 & 180 & 2 \\
\hline 118 & Bradfield Canal & 0 & 0 & 0 & 0 & 0 & 0 & 0 & 0 & 0 & 0 \\
\hline 119 & Craig & 14 & 18 & 101 & 3 & 137 & 0 & 48 & 0 & 6 & 0 \\
\hline 120 & Ketchikan & 0 & 0 & 2 & 0 & 0 & 0 & 0 & 0 & 3 & 0 \\
\hline 121 & Dixon Entrance & 0 & 0 & 1 & 14 & 0 & 0 & 0 & 0 & 0 & 0 \\
\hline 123 & Hagemeister Island & 0 & 0 & 0 & 0 & 0 & 0 & 0 & 0 & 0 & 0 \\
\hline 127 & Afognak & 0 & 0 & 0 & 0 & 0 & 32 & 0 & 0 & 0 & 0 \\
\hline 133 & Chignik & 0 & 0 & 0 & 0 & 0 & 0 & 0 & 0 & 0 & 0 \\
\hline 135 & Trinity Islands & 0 & 0 & 0 & 0 & 0 & 38 & 35 & 5 & 0 & 63 \\
\hline 138 & Port Moller & 0 & 0 & 0 & 0 & 0 & 0 & 0 & 0 & 0 & 10 \\
\hline & TOTALS & 376 & 681 & 1,871 & 427 & 308 & 4,889 & 6,544 & 9,292 & 10,439 & 12,793 \\
\hline
\end{tabular}

${ }^{\mathrm{a} C}$ Company records.

bVarious sources.

SOURCE: State of Alaska Division of Mining, Land \& Water Kardex file, DNR Public Information Center and Land Recrods Information Section, DNR. 
APPENDIX B

Prospecting sites in Alaska 1995-1999

\begin{tabular}{|c|c|c|c|c|c|c|c|c|c|c|c|c|c|c|c|c|}
\hline Quad & Quad name & 1995 & 1995 & 1995 & 1996 & 1996 & 1996 & 1997 & 1997 & 1997 & 1998 & 1998 & 1998 & 1999 & 1999 & 1999 \\
\hline no. & & New & Extended & Total & New & Extended & Total & New & Extended & Total & New & Extended & Total & New & Extended & Total \\
\hline 17 & Point Hope & 9 & 0 & 9 & 0 & 0 & $\mathbf{0}$ & 0 & 0 & 0 & 0 & 0 & $\mathbf{0}$ & 0 & 0 & 0 \\
\hline 18 & DeLong Mountains & 0 & 0 & 0 & 0 & 0 & 0 & 0 & 0 & 0 & 0 & 0 & 0 & 27 & 0 & 27 \\
\hline 19 & Misheguk Mts. & 0 & 0 & 0 & 0 & 0 & $\mathbf{0}$ & 0 & 0 & 0 & 0 & 0 & $\mathbf{0}$ & 0 & 0 & 0 \\
\hline 26 & Noatak & 16 & 0 & 16 & 32 & 0 & 32 & 0 & 0 & 0 & 0 & 0 & $\mathbf{0}$ & 0 & 0 & 0 \\
\hline 27 & Baird Mts. & 6 & 0 & 6 & 9 & 0 & 9 & 0 & 0 & 0 & 0 & 0 & $\mathbf{0}$ & 0 & 0 & 0 \\
\hline 28 & Ambler River & .. & - & -- & - & - & - & - & - & - & 0 & 10 & 10 & 0 & 0 & 0 \\
\hline 30 & Wiseman & 10 & 0 & 10 & 61 & 0 & 61 & 10 & 5 & 15 & 25 & 0 & 25 & 0 & 12 & 12 \\
\hline 31 & Chandalar & 2 & 5 & 7 & 28 & 0 & 28 & 34 & 0 & 34 & 15 & 0 & 15 & 14 & 14 & 28 \\
\hline 33 & Coleen & $\cdots$ & - & $\cdots$ & $\cdots$ & $\cdots$ & - & $\cdots$ & - & - & 0 & 13 & 13 & 0 & 0 & 0 \\
\hline 36 & Selawik & $\cdots$ & - & - & $\cdots$ & $\cdots$ & $\cdots$ & - & - & - & 3 & 0 & 3 & 1 & 0 & 1 \\
\hline 38 & Hughes & -. & . & .. & - & $\cdots$ & -. & - & - & - & 0 & 4 & 4 & 1 & 0 & 1 \\
\hline 43 & Teller & 0 & 0 & 0 & 0 & 0 & 0 & 0 & 0 & 0 & 0 & 0 & 0 & 3 & 0 & 3 \\
\hline 44 & Bendeleben & 5 & 4 & 9 & 48 & 0 & 48 & 28 & 16 & 44 & 0 & 26 & 26 & 4 & 0 & 4 \\
\hline 45 & Candle & 5 & 0 & 5 & 8 & 0 & 8 & 91 & 0 & 91 & 0 & 27 & 27 & 6 & 8 & 14 \\
\hline 47 & Melozitna & 0 & 0 & 0 & 222 & 128 & 350 & 0 & 96 & 96 & 0 & 6 & 6 & 8 & 0 & 8 \\
\hline 48 & Tanana & 54 & 15 & 69 & 309 & 133 & 442 & 21 & 193 & 214 & 2 & 0 & 2 & 171 & 0 & 171 \\
\hline 49 & Livengood & 324 & 38 & 362 & 43 & 194 & 237 & 162 & 34 & 196 & 162 & 0 & 162 & 90 & 103 & 193 \\
\hline 50 & Circle & 169 & 85 & 254 & 136 & 166 & 302 & 189 & 110 & 299 & 276 & 142 & 418 & 93 & 61 & 154 \\
\hline 52 & Nome & 45 & 10 & 55 & 96 & 34 & 130 & 52 & 45 & 97 & 16 & 28 & 44 & 21 & 0 & 21 \\
\hline 53 & Solomon & 19 & 1 & 20 & 29 & 5 & 34 & 11 & 38 & 49 & 8 & 12 & 20 & 10 & 0 & 10 \\
\hline 55 & Nulato & 0 & 0 & 0 & 4 & 0 & 4 & 6 & 0 & 6 & 0 & 0 & 0 & 22 & 0 & 22 \\
\hline 56 & Ruby & 0 & 0 & 0 & 21 & 0 & 21 & 70 & 18 & 88 & 47 & 31 & 78 & 8 & 39 & 47 \\
\hline 57 & Kantishna River & 0 & 0 & o & 0 & 0 & o & 0 & 0 & 0 & 0 & 5 & 5 & 0 & 0 & 0 \\
\hline 58 & Fairbanks & 85 & 17 & 102 & 124 & 20 & 144 & 58 & 33 & 91 & 77 & 20 & 97 & 22 & 39 & 61 \\
\hline 59 & Big Delta & 45 & 33 & 78 & 102 & 42 & 144 & 286 & 16 & 302 & 1,849 & 230 & 2,079 & 977 & 1,332 & 2,309 \\
\hline 60 & Eagle & 34 & 7 & 41 & 48 & 11 & 59 & 67 & 48 & 115 & 263 & 88 & 351 & 29 & 144 & 173 \\
\hline 64 & Ophir & 0 & 0 & 0 & 0 & 0 & $\mathbf{0}$ & 33 & 0 & 33 & 0 & 43 & 43 & 0 & 0 & 0 \\
\hline 65 & Medfra & 3 & 0 & 3 & 16 & 0 & 16 & 28 & 8 & 36 & 0 & 0 & $\mathbf{0}$ & 2 & 0 & 2 \\
\hline 67 & Healy & 12 & 0 & 12 & 112 & 7 & 119 & 472 & 119 & 591 & 260 & 355 & 615 & 15 & 46 & 61 \\
\hline 68 & Mt. Hayes & 2 & 12 & 14 & 236 & 12 & 248 & 230 & 30 & 260 & 81 & 97 & 178 & 29 & 63 & 92 \\
\hline 69 & Tanacross & 6 & 166 & 172 & 68 & 0 & 68 & 38 & 15 & 53 & 53 & 38 & 91 & 171 & 39 & 210 \\
\hline 73 & Iditarod & 0 & 0 & 0 & 182 & 0 & 182 & 4 & 66 & 70 & 16 & 7 & 23 & 0 & 0 & 0 \\
\hline 74 & McGrath & 6 & 0 & 6 & 13 & 6 & 19 & 203 & 12 & 215 & 53 & 89 & 142 & 92 & 0 & 92 \\
\hline
\end{tabular}




\section{APPENDIX B}

Prospecting sites in Alaska 1995-1999

(continued)

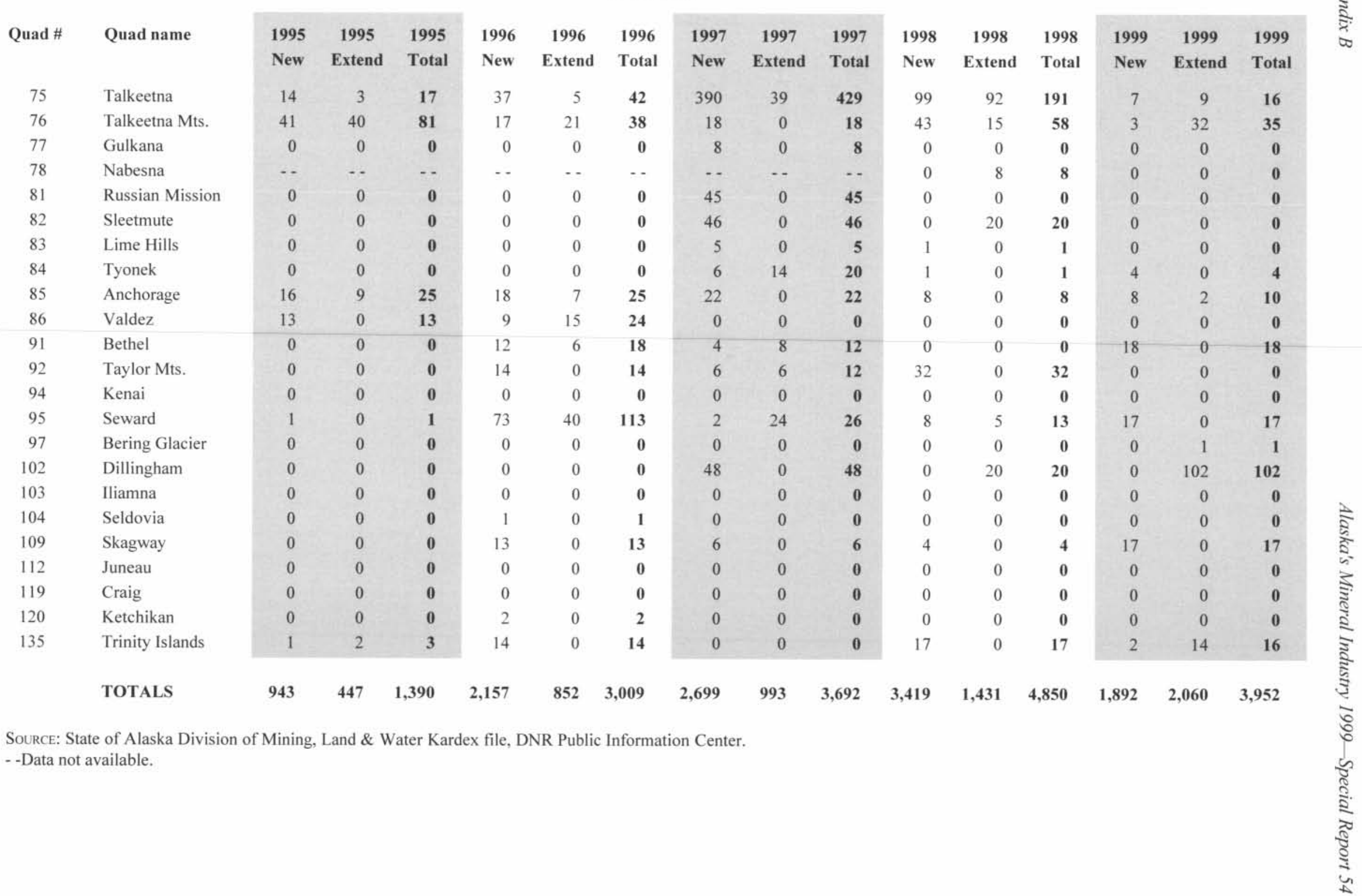




\section{APPENDIX C}

\section{Mining licenses issued by and received from the Alaska Department of Revenue and the Alaska Division of Mining, Land \& Water, 1999}

Entries include in this order: company name (region), address, resource, site of operation, mining district, and license number. Alaska Peninsula Region (APR), Eastern Interior Region (EIR), Northern Region (NR), Southcentral Region (SCR), Southwestern Region (SWR), Southeastern Region (SER), Undistributed (UR), Western Region (WR), and not given (NG).

Ackels, Del M. (NR)

1725 Roosevelt St.

Fairbanks, AK 99709-5112

Gold

Big Creek

Chandalar district

Adler, Kevin P. (SCR)

11976 Wilderness Dr.

Anchorage, AK 99516-2238

Gold

Peters Creek

Yentna district

Agoff, Alvin H. (SWR)

PO Box 2791

Palmer, AK 99645-2791

Gold

Prince Creek

Iditarod district

Alaska Gold Co. (WR)

PO Box 640

Nome, AK 99762-0640

Gold

Anvil Creek

Nome district

Alaska Gold Co. (WR)

PO Box 640

Nome, AK 99762-0640

Gold

Anvil Creek

Nome district

Alaska Gold Co. (EIR)

PO Box 71170

Fairbanks, AK 99707-1170

Gold

Cleary Creek

Fairbanks district

Alaska Gold Co. (EIR)

PO Box 71170

Fairbanks, AK 99707-1170

Gold

Little Eldorado Creek

Fairbanks district

Alaska Gold Co. (EIR)

PO Box 71170

Fairbanks, AK 99707-1170

Gold

Ester Creek

Fairbanks district

Alaska Gold Co. (WR)

PO Box 640

Nome, AK 99762-0640

Gold
Bear Creek

Hughes district

Alaska Gold Co. (WR)

PO Box 640

Nome, AK 99762-0640

Gold

Dry Creek

Nome district

Alaska Gold Co. (EIR)

PO Box 71170

Fairbanks, AK 99707-1170

Gold

Goldstream Creek

Fairbanks district

Alaska Gold Co. (WR)

PO Box 640

Nome, AK 99762-0640

Gold

Center Creek

Nome district

Alaska Gold Co. (WR)

PO Box 640

Nome, AK 99762-0640

Gold

Dry Creek

Nome district

Alaska/Nevada Gold Mines (EIR)

626 Second St. Ste. 202

Fairbanks, AK 99701-3466

Gold

Livengood Creek

Tolovana district

Alaska Pacific Trust Co.

(EIR)

PO Box 71230

Fairbanks, AK 99707-1230

Gold

Goldstream Creek

Fairbanks district

Aldridge, Shirley B. (EIR)

PO Box 1334

Palmer, AK 99645-1334

Gold

Poker Creek

Fortymile district

Aldridge, William J. (EIR)

PO Box 1334

Palmer, AK 99645-1334

Gold

Poker Creek

Fortymile district
Aldridge, William J. (EIR)

PO Box 1334

Palmer, AK 99645-1334

Gold

Turk Creek

Fortymile district

Alminco Alaska Mining Co.

Inc. (NR)

PO Box 91219

Anchorage, AK 99509-1219

Gold

Hammond River

Koyukuk district

American Metals Exploration

Inc. (NR)

c/o Bogle \& Gates Law Offices

$1031 \mathrm{~W}$ 4th Ave. $\# 600$

Anchorage, AK 99501-5907

Gold

Big Creek

Chandalar district

Amidon, Steven C. (SCR)

1925 Buckeye Ln.

Wasilla, AK 99654-3125

Gold

Thunder Creek

Yentna district

Anderson II, Allan G. (WR)

PO Box 37

McGrath, AK 99627-0037

Gold

Dodge Creek

Innoko district

Anderson, Gerald I. (SCR)

11920 Northern Raven Dr.

Anchorage, AK 99516-1935

Gold

Yacko Creek

Nelchina district

Anderson, Ralph S. (WR)

PO Box 1974

Nome. AK 99762-1974

Gold

Coffee Creek

Kougarok district

Anderson, Randi M. (EIR)

1901 Cheechako Dr.

Fairbanks. AK 99709-6542

Gold

Tenderfoot Creek

Fairbanks district
Andresen, John R. (EIR)

PO Box 10263

Fairbanks, AK 99710-0263

Gold

Dome Creek

Fairbanks district

Angell, William(EIR)

417 Glacier Ave.

Fairbanks, AK 99701-3722

Gold

Fortymile River

Fortymile district

Arctic Whitney Inc. (WR)

PO Box 782

Nome, AK 99762-0782

Gold

Norton Sound

Nome district

Arctic Whitney Inc. (WR)

PO Box 782

Nome, AK 99762-0782

Gold

Norton Sound

Nome district

Argo, Adam T. (EIR)

3705 Arctic Blvd. \# 957

Anchorage, AK 99503-5774

Gold

Mosquito Fork

Fortymile district

Babcock, Jack G. (EIR)

1650 Appaloosa Ln.

Fairbanks, AK 99709-6729

Gold

Switch Creek

Circle district

Babcock, Patricia R. (EIR)

1650 Appaloosa Ln.

Fairbanks, AK 99709-6729

Gold

Switch Creek

Circle distric

Bailey, George D. (EIR)

PO Box 2052

Fairbanks, AK 99701-2052

Gold

Fox Creek

Fairbanks district

Bartholomae, Bill A. (WR)

PO Box 2701

Orange, CA 92859-2701

Gold 
Gold Run Creek

Port Clarence district

Bauer, Tod A. (SCR)

PO Box 871502

Wasilla. AK 99687-1502

Gold

Eldorado Creek

Valdez Creek district

Baughman, Errol G. (EIR)

HC 69 Box 91

Belle Fourche, SD 57717-8801

Gold

Gilmore Creek

Fairbanks district

Beck Jr., Jessie D. (EIR)

PO Box 867

Tok. AK 99780-0867

Gold

South Fork Fortymile River

Fortymile district

Beerman Jr., William J. (SCR)

$2416 \mathrm{~S} 1 \mathrm{st}$ St.

Yakima. WA 98903-1552

Gold

Big Four Creek

Chistochina district

Beerman, William J. (SCR)

$2416 \mathrm{~S}$ Ist St.

Yakima. WA 98903-1552

Gold

Big Four Creek

Chistochina district

Beistline, Earl H. (EIR)

PO Box 80148

Fairbanks, AK 99708-0148

Gold

Goldstream Creek

Fairbanks district

Benesch, George (WR)

PO Box 101558

Anchorage. AK 99510-1558

Gold

Coffee Creek

Kougarok district

Berg, Carol B. (EIR)

450 Westridge Dr.

Portola Valley, CA 94028-7719

Gold

Ester Creek

Fairbanks district

Berg, Rhinehart M./Thorleif

Wetlesen, Estate of WR)

c/o Wallis W Brooks

325 Garrison Way

Gulph Mills. PA 19428

Gold

Candle Creek

Fairhaven district

Berg, Rhinehart M./Thorleif

Wetlesen, Estate of WR)

c/o Wallis W. Brooks
325 Garrison Way

Gulph Mills, PA 19428

Gold

Candle Creek

Fairhaven district

Bergman, Kevin M. (EIR)

PO Box 71488

Fairbanks, AK 99707-1488

Gold

Ester Creek

Fairbanks district

Berry, William F. (EIR)

450 Westridge Dr.

Portola Valley, CA 94028-7719

Gold

Ketchum Creek

Circle district

Berry, William F. (EIR)

450 Westridge Dr.

Portola Valley, CA 94028-7719

Gold

Ester Creek

Fairbanks district

Bickell, D. Harvey (EIR)

Rr1 Site 7

Gabriola B.C.

Gold

Walker Fork

Fortymile district

Billings, Henry C. (EIR)

80 W Gibson St.

Canandaigua, NY 14424-1453

Gold

Totatlanika River

Bonnifield district

Black, Dennis (NR)

PO Box 80930

Fairbanks, AK 99708-0930

Gold

Big Creek

Chandalar district

Blair, Patricia A. (SCR)

PO Box 572

Cooper Landing, AK 99572

Gold

Quartz Creek

Seward district

\section{Boundary 8 (EIR)}

c/o Norman Laframboise

1001328 Commissioner's Rd. W.

London. Ontario N6K2Y6

Canada

Gold

Turk Creek

Fortymile district

Bouton, Glenn D. (NR)

855 Cranberry Ridge Dr.

Fairbanks. AK 99712-1104

Gold

Chapman Creek

Koyukuk district
Bouton, Lela (NR)

855 Cranberry Ridge Dr.

Fairbanks, AK 99712-1104

Gold

Chapman Creek

Koyukuk district

Bradley, Joe (SCR)

529 Lynwood Dr.

Anchorage, AK 99518-1856

Gold

Skookum Creek

Yentna district

Brandl, Philip A. (SCR)

14251 Sabine St.

Anchorage, AK 99516-3912

Gold

Cache Creek

Yentna district

Brandl, Philip A. (SCR)

14251 Sabine St.

Anchorage. AK 99516-3912

Gold

Cache Creek

Yentna district

BrandI, Philip A. (SCR)

14251 Sabine St.

Anchorage, AK 995163912

Gold

Cache Creek

Yentna district

Bras, Cy (EIR)

703 Swires Rd.

Kenai. AK 99611-8391

Gold

Canyon Creek

Fortymile district

Brexco Inc. (NR)

423 E 5th Ave.

Anchorage, AK 99501

Gold

Lake Creek

Koyukuk district

Briley, Robert A. (EIR)

PO Box 10585

Fairbanks. AK 99710-1585

Gold

Nugget Creek

Fairbanks district

Brittan, Jon (WR)

PO Box 1313

Nome. AK 99762-1313

Gold

Norton Sound

Nome district

Brooks Range Ventures Inc. (NR)

423 E 5th Ave.

Anchorage. AK 99501-2634

Gold

Lake Creek

Kovukuk district
Brooks, Wallis (WR)

Berg/Wetlesen Estate

325 Garrison Way

Gulph Mills, PA 19428

Gold

Candle Creek

Fairhaven district

Bryant, Thomas L. (NR)

PO Box 264

Ridgway, CO 81432-0264

Gold

Hammond River

Koyukuk district

Bryant, Thomas L. (NR)

PO Box 264

Ridgway, CO 81432-0264

Gold

Chapman Creek

Koyukuk district

Bucy, Michael (EIR)

3638 Dunkirk Dr.

Anchorage, AK 99502-3060

Gold

Warner Creek

Fortymile district

Burns, John R. (EIR)

PO Box 5

Chicken, AK 99732-0005

Gold

Davis Creek

Fortymile district

Busby, Michael R. (EIR)

4481 W Hill Rd.

Homer, AK 99603-8302

Gold

Chicken Creek

Fortymile district

Busk, Leroy (SWR)

PO Box 190649

Anchorage. AK 99519-0649

Gold

Syneva Creek

Aniak district

Busk, Richard L. (SWR)

PO Box 190649

Anchorage. AK 99519-0649

Gold

Syneva Creek

Aniak district

Calista Corporation (SWR)

301 Calista Court Ste. A

Anchorage, AK 99518-3028

Gold

Spruce Creek

Aniak district

Calista Corporation (SWR)

301 Calista Court Ste. A

Anchorage. AK 99518-3028

Gold

Queen Gulch

Iditarod district 
Carlo, Kenneth J. (EIR)

2113 Southern Ave.

Fairbanks, AK 99709-4240

Gold

Hunter Creek

Rampart district

Cariton, Allen (EIR)

631897 th Dr. NE

Everett, WA 98205-1011

Gold

Mosquito Fork

Fortymile district

Carlton, Norma (EIR)

631897 th Dr. NE

Everett, WA 98205-1011

Gold

Mosquito Fork

Fortymile district

Carr, Brad (EIR)

PO Box 25

Chicken, AK 99732-0025

Gold

South Fork Fortymile River

Fortymile district

Carr, Brad (EIR)

PO Box 25

Chicken, AK 99732-0025

Gold

Fortymile River

Fortymile district

Catt, Barbara J. (EIR)

PO Box 45

Central, AK 99730-0045

Gold

Crooked Creek

Circle district

Catt, D. Bruce (EIR)

PO Box 45

Central, AK 99730-0045

Gold

Crooked Creek

Circle district

Cavanagh, James D. (WR)

PO Box 80787

Fairbanks, AK 99708-0787

Gold

Crescent Creek

Innoko district

Christensen, Kathleen (SCR)

PO Box 871075

Wasilla, AK 99687-1075

Gold, heavy metals

Beach Sands

Yakataga district

Christensen, Robert E. (SCR)

PO Box 871075

Wasilla, AK 99687-1075

Gold, heavy metals

Beach Sands

Yakataga district
Clark, Douglas M. (WR)

PO Box 586

Talkeetna, AK 99676-0586

Gold

Ganes Creek

Innoko district

Clay, Barry L.

HC5 Box 6765 a

Palmer, AK 99645-9611

Gold

Swift Creek

Ruby district

Cloyd, Donald R. (NR)

8650 Cameron St.

Anchorage, AK 99507-3519

Gold

Lake Creek

Koyukuk district

Coggins, Anette (WR)

PO Box 3427

Homer. AK 99603-3427

Gold

Lower Willow

Nome district

Coggins, Anette (WR)

PO Box 3427

Homer, AK 99603-3427

Gold

Norton Sound

Nome district

Coggins, Craig C. (WR)

PO Box 3427

Homer, AK 99603-3427

Gold

Lower Willow

Nome district

Coggins, Craig C. (WR)

PO Box 3427

Homer, AK 99603-3427

Gold

Norton Sound

Nome district

Coiner, Doris (SCR)

1831 Balsam Rd. NW

Bemidji, MN 56601-8166

Gold

Valdez Creek

Valdez Creek district

Cole, John H. (EIR)

PO Box 10139

Fairbanks, AK 99710-0139

Gold

Portage Creek

Circle district

Compass Mining Inc. (NR)

PO Box 72700

Fairbanks. AK 99707-2700

Gold

Linda Creek

Koyukuk district
Comstock, B. W. (WR)

10508 Fawn Dr. NW

Gig Harbor, WA 98332-9510

Gold

Candle Creek

Fairhaven district

Cope, Roger C. (EIR)

PO Box 75404

Fairbanks, AK 99707-5404

Gold

Lewis Creek

Fairbanks district

Cornelius, Fred G. (EIR)

1615 Madison Dr.

Fairbanks, AK 99709-5033

Gold

Fox Creek

Fairbanks district

Coup, Cindy (NR)

PO Box 1574

Soldotna, AK 99669-1574

Gold

South Fork Koyukuk River

Koyukuk district

Coup, Joe (NR)

PO Box 1574

Soldotna, AK 99669-1574

Gold

South Fork Koyukuk River

Koyukuk district

Cox, Cecil (EIR)

PO Box 16213

Two Rivers, AK 99716

Gold

Fortymile River

Fortymile district

Cox, Jamie C. (EIR)

PO Box 16213

Two Rivers, AK 99716

Gold

Fortymile River

Fortymile district

Daugherty, Joe A. (SWR)

HC 05, Box 9749

Palmer, AK 99645-9509

Gold

Taylor Creek

Aniak distric

Delima, Don P. (EIR)

PO Box 56106

Manley Hot Springs, AK 997560106

Gold

Golden Creek

Hot Springs district

Dewitt, Estill (SCR)

200 W 34 th Ave. \# 843

Anchorage, AK 99503-3969

Gold

Alfred Creek

Willow Creek district
Doyon Ltd. (SCR)

201 First Ave. Ste. 300

Fairbanks, AK 99701-4848

Gold

Candle Creek

McGrath district

Doyon Ltd. (EIR)

201 First Ave. Ste. 300

Fairbanks, AK 99701-4848

Gold

American Creek

Fortymile district

Doyon Ltd. (EIR)

201 First Ave. Ste. 300

Fairbanks, AK 99701-4848

Gold

Cache Creek

Hot Springs district

Doyon Ltd. (EIR)

201 First Ave. Ste. 300

Fairbanks, AK 9970-4848

Gold

Woodchopper Creek

Hot Springs district

Eagan, Dan F. (EIR)

1564 Hilton Ave.

Fairbanks, AK 99701-4016

Gold

Goldstream Creek

Fairbanks district

Eagan, Peter (EIR)

PO Box 71170

Fairbanks, AK 99707

Gold

Kokomo Creek

Fairbanks district

\section{Earth Movers Of Fairbanks}

Inc. (EIR)

925 Aurora Dr.

Fairbanks, AK 99709-5538

Gold

Fairbanks Creek

Fairbanks district

Eaves, Samuel E. (EIR)

PO Box 10357

Fairbanks, AK 99710-0357

Gold

Livengood Creek

Tolovana district

Edgerton, Judd (EIR)

PO Box 34

Chicken. AK 99732-0034

Gold

Napoleon Creek

Fortymile district

Ellis, Edward E. (SCR)

PO Box 13443

Trapper Creek, AK 99683-0443

Gold

Lake Creek

Yentna district 
Emerson, Robert C. (EIR) 1811 Phillips Field Rd. Fairbanks, AK 99701-2706 Gold

N/A

Fairbanks district

Erikson, Gerald (EIR)

119 Charles St.

Fairbanks, AK 99701-3064

Gold

Fox Creek

Fairbanks district

Faa, Thomas E. (EIR)

PO Box 10906

Fairbanks, AK 99710-0906

Gold

Moose Creek

Bonnifield district

Fairbanks Exploration Inc. (EIR)

PO Box 73795

Fairbanks. AK 99707-3795

Industrial

N/A

Tolovana district

Fairbanks Gold Mining Inc. (EIR)

PO Box 73726

Fairbanks, AK 99707-3726

Gold

Gilmore Creek

Fairbanks district

Faulkner Sr, Harry E. (SWR)

PO Box 1307

Bethel, AK 99559-1307

Gold

Hot Springs

Aniak district

Faulkner, Eddie (SWR)

PO Box 1307

Bethel, AK 99559-1307

Gold

Hot Springs

Aniak district

Faulkner, Elizabeth (SWR)

PO Box 1307

Bethel, AK 99559-1307

Gold

Hot Springs

Aniak district

Faulkner, Jeannine P. (SWR)

PO Box 1307

Bethel, AK 99559-1307

Gold

Hot Springs

Aniak district

Fausett, Lonnie (WR)

$228 \mathrm{E} 350 \mathrm{~S}$

Farmington, UT 84025-3209

Gold

Norton Sound

Nome district
Fejes, William (NR)

PO Box 430

Homer, AK 99603-0430

Gold

Boulder Creek

Koyukuk district

Fichtelman, Guy (EIR)

414 Hawk Eye Downs Dr.

Fairbanks, AK 99712-1213

Gold

Mosquito Fork

Fortymile district

Flothe, Milo Ellsworth, Estate of (SCR)

PO Box 242

Sterling, AK 99672-0242

Gold

Quartz Creek

Hope district

Flothe, Glenn M. (SCR)

PO Box 111968

Anchorage, AK 99511-1968

Gold

Quartz Creek

Hope district

Flothe, Winifred M. (SCR)

Route 2, Box 242

Sterling, AK 99672-0242

Gold

Quartz Creek

Hope district

Fogarty Sr., James L. (EIR)

3498 Laurance Rd.

North Pole, AK 99705-6705

Gold

Flume Creek

Fairbanks district

Fogarty, Sharon L. (EIR)

3498 Laurance Rd.

North Pole, AK 99705-6705

Gold

Flume Creek

Fairbanks district

Frantz, Peter Smith (NR)

PO Box 83172

Fairbanks, AK 99708-3172

Gold

Linda Creek

Koyukuk district

Frasier, James C. (EIR)

1000 Cannan Dr.

Angleton, TX 77515-3310

Gold

Deadwood Creek

Circle district

Fullerton, John E. (SWR) 16935 Maplewild Ave. SW Seattle, WA 98166-3165 Gold

Flat Creek

Iditarod district
Fullerton, John R. (SWR)

PO Box 593

Porterville, CA 93258-0593

Gold

Flat Creek

Iditarod district

Fulton, Gordon (EIR)

PO Box 115

Central, AK 99730-9999

Gold

Switch Creek

Circle district

Funkhouser, Gladys A. (EIR)

1336 W 6th Ave.

Anchorage, AK 99501-1912

Gold (Underground)

N/A

Fairbanks district

Funkhouser, Peter J. (EIR)

$1336 \mathrm{~W} 6$ th Ave.

Anchorage, AK 99501-1912

Gold (Underground)

N/A

Fairbanks district

Gagne, Suzanne (EIR)

3025 S Morgan Valley Dr.

Morgan, UT 84050-9666

Gold

Ester Creek

Fairbanks district

Garrett, Dennis R. (SCR)

PO Box 520481

Big Lake, AK 99652-0481

Gold

Gopher Gulch

Yentna district

Gavora, Steve (EIR)

1967 Camomille Ln.

Fairbanks, AK 99712-2926

Gold

Fairbanks Creek

Fairbanks distric

Gelvin, Stanley M. (EIR) PO Box 30149

Central, AK 99730-0149

Gold

Crooked Creek

Circle district

Gelvin, Stanley M. (EIR)

PO Box 30149

Central, AK 99730-0149

Gold

Crooked Creek

Circle district

Gelvin, Stanley M. (EIR)

PO Box 30149

Central, AK 99730-0149

Gold

Greenhorn Gulch

Circle district
Gerth, James R. (EIR)

1182 Copper St.

North Pole, AK 99705-5777

Gold

Younger Creek

Fortymile district

Gibson, Wayne E. (EIR)

1610 Southern Ave.

Fairbanks, AK 99709-4229

Gold

Golden Creek

Melozitna district

Girdwood Mining Co. (SCR)

PO Box 1089

Girdwood, AK 99587-1089

Gold

Crow Creek

Anchorage district

Glassburn, Don (EIR)

PO Box 107

Central, AK 99730-0107

Gold

Gold Dust

Circle district

Glidden, Ralph F. (EIR)

PO Box 104

Tok, AK 99780-0104

Gold

Chicken Creek

Fortymile district

Global Outdoors Inc. (WR) 43445 Business Park Dr. Ste. 113

Temecula, CA 92590-3671

Gold

Cripple River

Nome district

Globe Creek Mining Inc. (EIR)

1684 Chena Ridge Rd.

Fairbanks, AK 99709-2611

Limestone

N/A

Tolovana district

Gold Run Ltd. (WR)

1250 NE Loop 410 Ste. 900

San Antonio, TX 78209-1524

Gold

Gold Run Creek

Port Clarence district

Goldmark Minerals Alaska Inc. (EIR)

1760633 6th Ave. SW

Calgary

Gold

Walker Fork

Fortymile district

Gonzales, Richard (WR)

200 W 34th Ave. \#1183

Anchorage, AK 99503

Gold

Offshore

Nome district 
Goodson, Richard

107 Cushman St.

Fairbanks, AK 99701-4637

Gold

Seventymile River

Eagle district

Goresen, Dolores A. (SCR)

PO Box 91

Seward, AK 99664-0091

Gold

Tonsina Creek

Seward district

Goresen, Edmund J. (SCR)

PO Box 91

Seward, AK 99664-0091

Gold

Tonsina Creek

Seward district

Granath, Gene Alfred (SCR)

Box 574

Kenai, AK 99611-0574

Gold

Falls Creek

Seward district

Greatland Exploration Ltd. (WR)

3512 Campbell Airstrip Rd.

Anchorage, AK 99504-3838

Gold

Norton Sound

Nome district

Green, Rosanna (EIR)

3025 S Morgan Valley Dr.

Morgana, UT 84050-9666

Gold

Ester Creek

Fairbanks district

Groethe, Lenhart (WR)

PO Box 1504

Kodiak, AK 99615-1504

Gold

Tripple Creek

Nome district

Groppel, Chris L. (EIR)

PO Box 1060

Delta Junction, AK 99737-1060

Gold

Tenderfoot Creek

Fairbanks district

Guidotti, Derek J. (SCR)

PO Box 671727

Chugiak, AK 99567-1727

Gold

Valdez Creek

Valdez Creek district

Gurule, Joe I. (EIR)

PO Box 235869

Honolulu, HI 96823-3515

Gold

Mosquito Fork

Fortymile district
Gustafson, Aaron B. (WR)

8355 N Stony Mountain Way

Flagstaff, AZ 86001-7824

Gold

Norton Sound

Nome district

Hamm, Ralph D. (NR)

4843 Rose Valley Rd.

Kelso, WA 98626-9431

Gold

Porcupine Creek

Koyukuk district

Hammond, Charles R. (EIR) PO Box 7

Chicken, AK 99732-0007

Gold

45 Pup

Fortymile district

Hanks, G. A. (EIR)

Box 2533 Hwy. 16

West Sacramento, CA 95691

Gold

Lost Chicken

Fortymile district

Hanneman, Karl (EIR)

626 2nd St. Ste. 202a

Fairbanks, AK 99701-3466

Gold

Livengood Creek

Tolovana district

Harmon, Robert W. (WR)

PO Box 1472

Nome, AK 99762-1472

Gold

Norton Sound

Nome district

Harmon, Robert W. (WR)

PO Box 1472

Nome, AK 99762-1472

Gold

Norton Sound

Nome district

Harris, Donald D. (EIR)

$315 \mathrm{~S}$ Pearl St.

Centralia, WA 98531-4010

Gold

Slate Creek

Rampart district

Hart, Donald S. (EIR)

PO Box 172

Tok, AK 99780-0172

Gold

Jack Wade Creek

Fortymile district

Haskins, George R. (EIR)

PO Box 171

Healy, AK 99743

Gold

Goldstream Creek

Fairbanks district
Haskins, Laren S. (EIR)

PO Box 71777

Fairbanks, AK 99707-1777

Gold

Goldstream Creek

Fairbanks district

Hassel, Gerald L. (EIR)

PO Box 49

Ester. AK 99725-0049

Gold

Ready Bullion

Fairbanks district

Hayden, Forest A. (EIR)

PO Box 110930

Anchorage, AK 99511-0930

Gold

Kal Creek

Fortymile district

Hayden, Forest A. (EIR)

PO Box 110930

Anchorage, AK 99511-0930

Gold

Squaw Gulch

Fortymile district

Heflinger, Fred (EIR)

PO Box 82390

Fairbanks, AK 99708-2390

Gold

Walker Fork

Fortymile district

Hendrickson Jr., Jack (EIR)

PO Box 30153

Central. AK 99730-0153

Gold

Bottom Dollar

Circle district

Hendrickson, Agnes (SCR)

3549 Dunkirk Dr.

Anchorage, AK 99502-3059

Gold

Falls Creek

Seward district

Hendrickson, Michael (SCR)

3549 Dunkirk Dr.

Anchorage, AK 99502-3059

Gold

Falls Creek

Seward district

Henkel, F. E. (EIR)

412 Glacier

Fairbanks, AK 99701-3723

Gold

Fortymile River

Fortymile district

Henning, John (WR)

630 B Jack St.

Anchorge, AK 99515-3431

Gold

N/A - Beach

Nome district
Hess, Luther C. (EIR)

Estate Trust

PO Box 900

Anchorage, AK 99510-0900

Gold

Goldstream Creek

Fairbanks district

Holt, Laurie A. (SCR)

PO Box 598

Moose Pass, AK 99631-0598

Gold

Quartz Creek

Hope district

Holt, Ryan L. (SCR)

PO Box 598

Moose Pass, AK 99631-0598

Gold

Quartz Creek

Hope district

Hopen, Alf (EIR)

PO Box 74246

Fairbanks, AK 99707

Gold

Cleary Creek

Fairbanks district

Horner, George R. (EIR)

Trust

PO Box 60610

Fairbanks, AK 99710-0610

Gold

Goldstream Creek

Fairbanks district

Horner, Joann E. (EIR)

PO Box 60610

Fairbanks, AK 99706-0610

Gold

Goldstream Creek

Fairbanks district

Houser, Janice (EIR)

Box 12

Chicken, AK 99732

Gold

Fortymile River

Fortymile district

Jackson, O. L. (NR)

PO Box 248

La Center, WA 98629-0248

Gold

Jennie Creek

Koyukuk district

Jacobs, David W. (EIR)

HC 1 Box 3090

Healy, AK 99743-9603

Gold

Moose Creek

Bonnifield district

Jacobs, David W. (EIR)

HC 1 Box 3090

Healy, AK 99743-9603

Gold

Rex Creek

Bonnifield district 


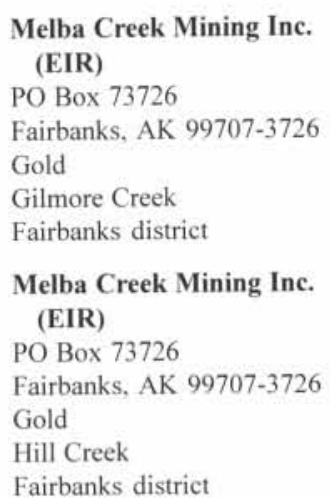

Merrill, Bruce (SCR)

15411 Husky St.

Eagle River, AK 99577-9246

Gold

Falls Creek

Seward district

Merrill, Ivan (SCR)

PO Box 3503

Seward, AK 99664

Gold

Falls Creek

Seward district

Midas Gold Resources Inc. (NR)

100 Cushman St., Ste. 311

Fairbanks, AK 99701-4659

Gold

Big Creek

Chandalar district

Minder, Richard B. (EIR)

PO Box 10263

Fairbanks, AK 99710-0263

Gold

Dome Creek

Fairbanks district

Mir Llc. (SCR)

c/o Stanley Pleninger

7410 Wade Cir.

Anchorage, AK 99518-2047

Gold

Valdez Creek

Valdez Creek district

Miscovich, Andrew W. (NR)

PO Box 71489

Fairbanks, AK 99707-1489

Gold

Porcupine Creek

Koyukuk district

Miscovich, Andrew W. (EIR) PO Box 71489

Fairbanks, AK 99707-1489

Gold

Wolf Creek

Fairbanks district

Miscovich, Andy E. (EIR)

PO Box 1489

Fairbanks, AK 99707-1489
Gold

Gilmore Creek

Fairbanks district

Miscovich, John A. (SWR)

1093 N Greengrove St.

Orange, CA $92867-5812$

Gold

Otter Creek

Iditarod district

Miscovich, Verda M. (NR)

PO Box 71489

Fairbanks, AK 99707-1489

Gold

Porcupine Creek

Koyukuk district

Miscovich, Verda M. (EIR) PO Box 71489

Fairbanks, AK 99707-1489

Gold

Gilmore Creek

Fairbanks district

Mitchell, Harold (EIR)

Rr. 1 Box 287

Baraga. MI 49908-9749

Gold

Mosquito Fork

Fortymile district

Mitchell, Joseph D. (EIR)

Rr. 1 Box 322

Brookville. PA 15825-9721

Gold

Fortymile River

Fortymile district

Mitchell, Mona (EIR)

Rr. I Box 322

Brookville, PA 15825-9721

Gold

Fortymile River

Fortymile district

Mitchell, Rodney D. (EIR)

3133 Chena Hot Springs Rd.

Fairbanks, AK 99712-3304

Gold

Grubstake Creek

Bonnifield district

Montgomery, Lois (EIR)

3643 Road Dr. NW

Ephrata, WA 98823-9790

Gold

Gilliland Creek

Fortymile district

Montgomery, Melvin (EIR)

3643 Road Dr. NW

Ephrata. WA 98823-9790

Gold

Jack Wade Creek

Fortymile district

Montgomery, Melvin (EIR)

3643 Road Dr. NW

Ephrata, WA 98823-9790

Gold
Gilliland Creek

Fortymile district

Monzulla, Linda (EIR)

2920 Monzulla Ln.

Fairbanks, AK 99712-1737

Gold-tungsten

Gilmore Creek

Fairbanks district

Monzulla, Vincent C.

(EIR)

Rt \# 1 Box 659a Ave I

Big Pine Key, FL 33043

Gold-tungsten

Gilmore Creek

Fairbanks district

Moore, Roger L. (EIR)

288 Rambling Rd $\# 26$

Fairbanks, AK 99712-1502

Gold

Ester Creek

Fairbanks district

Moran, Ted H. (SCR)

5611 Lionheart Dr.

Anchorage, AK 99508

Gold

Quartz Creek

Hope district

Mrak Aklestad Hermon \&

Hermon (SCR)

PO Box 1963

Palmer, AK 99645-1963

Gold

Willow Creek

Willow Creek district

Mtnt Native Corp. (SCR)

PO Box 309

McGrath. AK 99627-0309

Gold

Candle Creek

McGrath district

Mud Creek Mining Corp. (WR)

HC 1 Box 109

White Bird, ID 83554-9709

Gold

Mud Creek

Fairhaven district

N.B. Tweet \& Sons (WR)

PO Box 1107

Nome, AK 99762-1107

Gold

Kougarok River

Kougarok district

Neubauer, Jack A. (EIR)

413 Cowles St.

Fairbanks, AK 99701-4434

Gold

Cache Creek

Hot Springs district

Neubauer, Jack A. (EIR)

413 Cowles St.
Fairbanks, AK 99701-4434

Gold

Golden Creek

Hot Springs district

Nevers, Harold A. (EIR)

8148 Pinewood Dr

Juneau, AK 99801-8906

Gold

American Creek

Fortymile district

Newby Sr., Alan R. (EIR)

PO Box 55367

North Pole, AK 99705-5367

Gold

Little Boulder Creek

Hot Springs district

Nicholson, Douglas C.

(NR)

3865 Ullrbahn

Fairbanks, AK 99709-6106

Gold

Linda Creek

Koyukuk distric

Norcross, Irene E. (WR)

PO Box 242

Willow, AK 99688-0242

Gold

Anvil Creek

Innoko district

Norcross, James H. (WR)

PO Box 242

Willow. AK 99688-0242

Gold

Anvil Creek

Innoko district

Nordeen, Claudene (NR)

887 Bouton Ct.

Fairbanks, AK 99712-1448

Gold

Emma Creek

Koyukuk district

Nordeen, William H.

(NR)

887 Bouton $\mathrm{Ct}$.

Fairbanks, AK 99712-1448

Gold

Emma Creek

Koyukuk district

Northern Lights Mining Inc. (NR)

544 North 600 W

Cedar City, UT 84720-2111

Gold

Rye Creek

Koyukuk district

Northland Minerals, Inc. (SCR)

1817 Parkside Dr.

Anchorage, AK 99501-5751

Gold

Cache Creek

Yentna district 
Northland Minerals, Inc. (SCR)

1817 Parkside Dr.

Anchorage, AK 99501-5751

Gold

Cache Creek

Yentna district

Northland Minerals, Inc. (SCR)

1817 Parkside Dr.

Anchorage, AK 99501-5751

Gold

Cache Creek

Yentna district

Nugget Creek Mining (SCR)

1817 Parkside Dr.

Anchorage, AK 99501-5751

Gold

Cache Creek

Yentna district

Nyac Mining Co. (SWR)

$1634 \mathrm{~W} 13$ th Ave.

Anchorage, AK 99501-4217

Gold

Spruce Creek

Aniak district

O'Carroll, John, J., Estate of (WR)

44 West Blithedale Ave.

Mill Valley, CA 94941

Gold

Dodge Creek

Innoko district

O'Carroll, Ellen M., Estate of (SWR)

267 Sunset Way

Muir Beach, CA 94965-9752

Gold

Flat Creek

Iditarod district

Olmstead, Jim (NR)

c/o Richard L. Wright

3910 Tilleson Way

North Pole, AK 99705-6555

Gold

Gold Creek

Koyukuk district

Olson, Dave (WR)

PO Box 2159

Homer, AK 99603-2159

Gold

Canyon Creek

Nome district

Olson, Gordon E. (EIR)

7100 N Milford Rd.

Holly, MI 48442-8563

Gold

Jack Wade Creek

Fortymile district

Olson, Jeffrey G. (EIR)

408 E Exchange $\mathrm{St}$.

Spring Lake, MI 49456-1902
Gold

Jack Wade

Fortymile district

Olson, Judy (EIR)

7100 N Milford Rd.

Holly, MI 48442-8563

Gold

Jack Wade Creek

Fortymile district

Olson, Steven L. (EIR)

PO Box 10655

Fairbanks. AK 99710-0655

Gold

Eagle Creek

Circle district

On Line Expl. Sves. Inc. (EIR)

11976 Wilderness Dr.

Anchorage, AK 99516-2238

Gold

Specimen Creek

Delta River district

O'Riley, Roger (WR)

PO Box 603

Willamina, OR 97396-0603

Gold

N/A - Beach

Nome district

Ott, Richard K. (EIR)

PO Box 72748

Fairbanks, AK 99707-2748

Gold

Omega Creek

Hot Springs district

Ott, Wendy A. (EIR)

PO Box 72748

Fairbanks, AK 99707-2748

Gold

Omega Creek

Hot Springs district

Oudekerk, James A. (EIR)

PO Box 351

Healy, AK 99743-0351

Gold

Rex Creek

Bonnifield district

Owen, Jeffrey R. (EIR)

12307 E Stillwater Way

Redding, CA 96003-9540

Gold

Younger Creek

Fortymile district

Pacific Northwest Resources

Co. Inc. (EIR)

PO Box 4879

Vancouver, WA 98662-0879

Gold

Gilmore Creek

Fairbanks district

Patrick, Michael B. (EIR)

2015 S Main St.

Corona, CA. $91720-5345$
Gold

Fortymile River

Fortymile district

Pennell, Jack (EIR)

PO Box 1928

Grand Junction, CO 81502-1928

Gold

Little Boulder Creek

Hot Springs district

Penz, David C. (SWR)

Box 29

Russian Mission, AK 99657

Gold

Buster Creek

Marshall district

Petersen, Donald E. (SER)

PO Box 172

Haines, AK 99827-0172

Gold

Porcupine Creek

Juneau district

Peterson, Lawrence A. (WR)

118 Slater Dr.

Fairbanks, AK 99701-3428

Gold

Ganes Creek

Innoko district

Peterson, Lawrence A. (EIR)

118 Slater Dr

Fairbanks, AK 99701-3428

Gold

Little Eldorado

Fairbanks district

Pettigrew, Bert (WR)

PO Box 38

Ellensburg. WA 98926-0038

Gold

Anvil Creek

Nome district

Petty, Jack (EIR)

2305 E Polar Bear Ct.

North Pole, AK 99705-5500

Gold

Gilmore Creek

Fairbanks district

Philpott, Ellen (NR)

PO Box 72198

Fairbanks, AK 99707-2198

Gold

Smith Creek

Koyukuk district

Philpott, Roy (NR)

PO Box 72198

Fairbanks, AK 99707-2198

Gold

Smith Creek

Koyukuk district

Plano, Cynthia L. (WR)

PO Box 878275

Wasilla, AK 99687-8275
Gold

Anvil Creek

Innoko district

Plano, Daniel W. (WR)

PO Box 878275

Wasilla, AK 99687-8275

Gold

Anvil Creek

Innoko district

Polar Mining Inc. (EIR)

4545 Wood River Dr.

Fairbanks, AK 99709-3404

Gold

Goldstream Creek

Fairbanks district

Polley Jr., Everett J. (EIR)

10809 Oreland Mill Rd.

Louisville, KY 40229-2427

Gold

South Fork Fortymile River

Fortymile district

Polley, Margaret E. (EIR) 10809 Oreland Mill Rd.

Louisville, KY 40229-2427

Gold

South Fork Fortymile River

Fortymile district

Pomrenke, Steve G. (WR)

19579 63rd St.

Royalton, MN 56373-3727

Gold

Tripple Creek

Nome district

Pushcar, Jerry (WR)

PO Box 1604

Nome, AK 99762-1604

Gold

Iron Creek

Kougarok district

Raines, Larry R. (EIR)

1313 Skyline Dr.

Fairbanks, AK 997121151

Gold

Lewis Creek

Fairbanks district

Raines, Lindy L. (EIR)

1313 Skyline Dr.

Fairbanks, AK 99711-1151

Gold

Lewis Creek

Fairbanks district

Ramier, Brad(EIR)

PO Box 10570

Fairbanks, AK 99710-0570

Gold

N/A

Fairbanks district

Read, Donald M. (EIR)

PO Box 71638

Fairbanks, AK 99707-1638 
Gold

Treasure Creek

Fairbanks district

Read, Donald M. (EIR)

PO Box 71638

Fairbanks, AK 99707-1638

Gold

Vault Creek

Fairbanks district

Reed, Scott C. (EIR)

PO Box 121

Eagle, AK 99738-0121

Gold

N Fork Fortymile

Fortymile district

Reeves, John (EIR)

PO Box 81941

Fairbanks, AK 99708-1941

Gold

Goldstream Creek

Fairbanks district

Reeves, Ramona (EIR)

PO Box 81941

Fairbanks, AK 99708-1941

Gold

Goldstream Creek

Fairbanks district

Richardson, Ralph R. (EIR)

PO Box 4589

Palmer, AK 99645-4589

Gold

Hall Creek

Fortymile district

Roberts, Mike D. (EIR)

PO Box 82182

Fairbanks, AK 99708-2182

Gold

Ltl. Eldorado

Fairbanks district

Roberts, Robert W. (EIR)

PO Box 225

Tok, AK 99780-0225

Gold

Chicken Creek

Fortymile district

Roberts, Roger L. (WR)

300 E Dimond Blvd. Ste. 20

Anchorage, AK 99515-1949

Gold

Ophir Creek

Innoko district

Robison, Robert M. (NR)

760 E Martindale Ln.

Fillmore, UT 84631

Gold

Rye Creek

Koyukuk district

Roland, James G. (EIR)

710 McGrath Rd.

Fairbanks, AK 99712-1524
Gold

Moose Creek

Bonnifield district

Roland, James G. (EIR)

710 McGrath Rd

Fairbanks, AK 99712-1524

Gold

Rex Creek

Bonnifield district

Roland, James G. (EIR)

710 McGrath Rd.

Fairbanks, AK 99712-1524

Gold

Ester Creek

Fairbanks district

Roman, Ronald L. (EIR)

PO Box 71614

Fairbanks, AK 99707-1614

Gold

Hill Creek

Fairbanks district

Roop Sr., John A. (EIR)

9499 Brayton Dr. Lot 22

Anchorage, AK 99507-4004

Gold

Fortymile River

Fortymile district

Rosander Mining Company Inc. (WR)

PO Box 129

Mcgrath, AK 99627-0129

Gold

Colorado Creek

Innoko district

Ross, John (EIR)

776 Bullion Dr.

Fairbanks, AK 99712-2305

Gold

Kokomo Creek

Fairbanks district

Sanders, Kent (WR)

PO Box 2159

Homer, AK 99603-2159

Gold

Canyon Creek

Nome district

Sather, Norman M. (EIR)

1213 Coppet St.

Fairbanks, AK 99709-4724

Gold

Fairbanks Creek

Fairbanks district

Sather, Steven P. (EIR)

1488 Holy Cross Dr.

Fairbanks, AK 99709-6765

Gold

Fairbanks Creek

Fairbanks district

Saunders, Frank L. (EIR)

PO Box 449
Ester, AK 99725-0449

Gold

Ester Creek

Fairbanks district

Sayer, Paul (WR)

PO Box 10

Homer, AK 99603-0010

Gold

10 Pup Little Creek

Innoko district

Schasteen, Dolly (EIR)

410 Frankton Rd.

Hood River, OR 97031-9737

Gold

Moose Creek

Bonnifield district

Schnabel, Erma L. (SER)

PO Box 149

Haines, AK 99827-0149

Gold

Porcupine Creek

Juneau district

Schnabel, John J. (SER)

PO Box 149

Haines, AK 99827-0149

Gold

Porcupine Creek

Juneau district

Scofield, Walter P. (EIR)

PO Box 945

Tok, AK 99780-0945

Gold

South Fork Fortymile River

Fortymile district

Sebens, Mark W. (SER)

PO Box 1107

Haines, AK 99827-1107

Gold

Porcupine Creek

Juneau district

Seuffert Jr., George W. (EIR)

PO Box 68

Chicken, AK 99732-0068

Gold

Chicken Creek

Fortymile district

Seuffert Sr., George W. (EIR)

8191 E Del Joya Dr.

Scottsdale, AZ 85258-2337

Gold

Chicken Creek

Fortymile district

Shafer, Marion H. (EIR)

PO Box 21755

Juneau, AK 99802-1755

Gold

Ready Bullion Creek

Fairbanks district

Shilling, John A. (EIR)

924 W Chestnut St.
Houston, MO 65483-1820

Gold

Thanksgiving Creek

Hot Springs district

Shupe, Michael C. (NR)

1035 W Northern Lights Blvd.

Anchorage, AK 99503-2409

Gold

Boulder Creek

Koyukuk district

Simmons, Shianne (EIR)

PO Box 56331

North Pole, AK 99705-1331

Gold

Walker Fork

Fortymile district

Sitnasuak Native Corp. (WR) PO Box 905

Nome, AK 99762-0905

Gold

Dry Creek

Nome district

Skidmore Jr., Samuel C. (EIR)

PO Box 70470

Fairbanks, AK 99707-0470

Gold

Vault Creek

Fairbanks district

Skidmore, Donna G. (EIR)

PO Box 70470

Fairbanks, AK 99707-0470

Gold

Vault Creek

Fairbanks district

Slate Creek Mining Co. (EIR)

315 S Pearl St.

Centralia, WA 98531-4010

Gold

Slate Creek

Rampart district

Smith Jr., David B. (EIR)

3525 Holt Road

Fairbanks, AK 99701-7411

Gold

Deadwood Creek

Circle district

Smith Jr., David B. (EIR)

3525 Holt Road

Fairbanks, AK 99701-7411

Gold

Deadwood Creek

Circle district

Smith Sr., David B. (EIR)

9235 W Harbor Isle Ct.

Crystal River, FL 34429-5355

Gold

Deadwood Creek

Circle district

Smith, Lynda K. (SCR)

PO Box 681 
Cooper Landing, AK 99572

Gold

None

Seward district

Smith, Sherman C. (SCR)

PO Box 770

Cooper Landing, AK 99572 0770

Gold

None

Seward district

Smith, Stephen J. (EIR)

$6160 \mathrm{~W}$ Baghdad St.

Dunnellon, FL 34433-6512

Gold

Deadwood Creek

Circle district

Soule, Betty M. (SCR)

2840 E 142 nd Ave.

Anchorage, AK 99516-3903

Gold

Windy Creek

Yentna district

Soule, Harold L. (SCR)

2840 E 142nd Ave.

Anchorage, AK 99516-3903

Gold

Windy Creek

Yentna district

Spurlock, Taylor (WR)

43445 Business Park Dr. \#113

Temecula, CA 92590-3671

Gold

Cripple River

Nome district

Stardust Mining Inc. (EIR)

142 Steelhead Rd.

Fairbanks, AK 99709-3041

Gold

Colorado Gulch

Hot Springs district

State of Alaska (WR)

Division of Mining, Land \&

Water

3700 Airport Way

Fairbanks, AK 99707-4699

Gold

Norton Sound

Nome district

State of Alaska (WR)

Division of Mining, Land \&

Water

$550 \mathrm{~W} 7$ th Ave. $\# 900 \mathrm{~b}$

Anchorage, AK 99501-3577

Gold

Norton Sound

Nome district

State of Alaska (WR)

Division of Mining, Land \&

Water

3700 Airport Way
Fairbanks, AK 99707-4699

Gold

Norton Sound

Nome district

State of Alaska (WR)

Division of Mining, Land \& Water

3700 Airport Way

Fairbanks, AK 99707-4699

Gold

Norton Sound

Nome district

State of Alaska (WR)

Division of Mining, Land \& Water

3700 Airport Way

Fairbanks, AK 99707-4699

Gold

Norton Sound

Nome district

State of Alaska (WR)

Division of Mining, Land \& Water

3700 Airport Way

Fairbanks, AK 99707-4699

Gold

Norton Sound

Nome district

State of Alaska (WR)

Division of Mining, Land \& Water

3700 Airport Way

Fairbanks, AK 99707-4699

Gold

Norton Sound

Nome district

State of Alaska (WR)

Division of Mining, Land \& Water

3700 Airport Way

Fairbanks, AK 99707-4699

Gold

Norton Sound

Nome district

Stein, Donald R. (EIR)

105 Dunbar Ave.

Fairbanks, AK 99701-3658

Gold

Gilmore Creek

Fairbanks district

Stein, Donald R. (EIR)

105 Dunbar Ave.

Fairbanks, AK 99701-3658

Gold

Dome Creek

Fairbanks district

Stein, Evelyn J. (EIR)

105 Dunbar Ave.

Fairbanks, AK 99701-3658

Gold

Gilmore Creek

Fairbanks district
Stepp, Vernon E. (EIR)

290 Pearl Dr.

Fairbanks, AK 99712

Gold

Bottom Dollar Creek

Circle district

Sternberg, Thomas H. (SCR)

$3154 \mathrm{E} 19$ th $\mathrm{Ct}$.

Anchorage, AK 99508-3383

Gold

Quartz Creek

Hope district

Sternberg, Thomas H. (SCR)

3154 E 19 th Ct.

Anchorage, AK 99508-3383

Gold

Quartz Creek

Hope district

Stevens, Andrea A. (SWR) 621 Highview Dr.

Anchorage, AK 99515-3718

Gold

Marvel Creek

Aniak district

Stone, James T. (EIR)

PO Box 110842

Anchorage, AK 99511-0842

Gold

Porcupine Creek

Circle district

Stone, L.F. (EIR)

8196 East Cooper Lane

Floral City, FL 34436-2710

Gold

Deadwood Creek

Circle district

Strandberg Jr., Sigvald J. (WR)

PO Box 85125

Fairbanks, AK 99708

Gold

Crescent Creek

Innoko district

Strandberg Sr., Sigvald J.

(WR)

PO Box 80787

Fairbanks, AK 99708

Gold

Crescent Creek

Innoko district

Strandberg, Neil M. (WR)

PO Box 80787

Fairbanks, AK 99708

Gold

Crescent Creek

Innoko district

Stringfellow, JoAnn (EIR)

3051 Central Blvd.

Milford, MI 48380-2205

Gold

Jack Wade Creek

Fortymile district
Stringfellow, Ron (EIR)

3051 Central Blvd.

Milford, MI 48380-2205

Gold

Jack Wade Creek

Fortymile district

Swarthout, Ralph J. (SCR)

PO Box 141801

Anchorage, AK 99514-1801

Gold

Beach Sands

Yakataga district

Sweetsir, Michael A.

PO Box 51

Ruby, AK 99768

Gold

Glen Gulch

Ruby district

Swenson, Lloyd D. (NR)

1843 Bridgewater Dr.

Fairbanks, AK 99709-4102

Gold

Slate Creek

Koyukuk district

Swenson, Richard A. (EIR)

PO Box 16205

Two Rivers, AK 99716-0205

Gold

Doric Creek

Hot Springs district

Taiga Mining Co. Inc. (WR)

PO Box 113108

Anchorage, AK 99511-3108

Gold

Bear Creek

Hughes district

Taiga Mining Co. Inc. (WR)

PO Box 113108

Anchorage, AK 99511-3108

Gold

Dry Creek

Hughes district

Tallini, Roger P. (EIR)

PO Box 3474

Flagstaff, AZ 86003-3474

Gold

Fortymile River

Fortymile district

Tatlow, Carl (SCR)

PO Box 1621

Palmer, AK 99645-1621

Gold

Peters Creek

Yentna district

Tatlow, Janice L. (SCR)

PO Box 1621

Palmer, AK 99645

Gold

Peters Creek

Yentna district

Taylor, June M. (EIR)

PO Box 101 
Eagle, AK 99738-0101

Gold

Fortymile River

Fortymile district

Taylor, Larry R. (EIR)

PO Box 101

Eagle, AK 99738-0101

Gold

Fortymile River

Fortymile district

Tengs, Martin A. (SER)

PO Box 148

Haines, AK 99827-0148

Gold

Porcupine Creek

Juneau district

Teryl Resources Corp. (EIR)

\# 185-10751 Shellbridge Way

Richmond, B.C. V6X 2W8

Canada

Gold

Gilmore Creek

Fairbanks district

This Corporation (WR)

8916 Windwood St.

Wichita. KS 67226

Gold

Offshore

Nome district

Thomas, Scott A. (EIR)

663 Tonsina Dr.

Fairbanks. AK 99712-2038

Gold

Half Dollar Creek

Circle district

Thompson, Kevin D. (SCR)

PO Box 875534

Wasilla, AK 99687-5534

Gold

Roosevelt Creek

Valdez Creek district

Thurman Oil and Mining Inc. (EIR)

925 Aurora Dr.

Fairbanks. AK 99709-5506

Gold

Smallwood Creek

Fairbanks district

Thurman, James L. (EIR)

925 Aurora Dr.

Fairbanks, AK 99709-5538

Gold

Goldstream Creek

Fairbanks district

Thurman, Leta (EIR)

925 Aurora Dr.

Fairbanks, AK 99709-5538

Gold

Goldstream Creek

Fairbanks district
Thurneau, Carol A. (EIR)

1573 Farmers Loop Rd.

Fairbanks, AK 99709-6707

Gold

Fortymile River

Fortymile district

Thurneau, Vernon A. (EIR)

1573 Farmers Loop Rd.

Fairbanks, AK 99709-6707

Gold

Fortymile River

Fortymile district

Titchenal, Robert L. (SCR)

4501 Montrose Cir.

Anchorage, AK 99515-1138

Gold

Busch Creek

Valdez Creek district

Toohey, Camden W. (SCR)

PO Box 113

Girdwood, AK 99587-0113

Gold

Crow Creek

Anchorage district

Toohey, Cynthia D. (SCR)

2642 Forrest Park Dr.

Anchorage, AK 99517-1326

Gold

Crow Creek

Anchorage district

Toohey, Sean (SCR)

PO Box 113

Girdwood, AK 99587-0113

Gold

Crow Creek

Anchorage district

Treesh, James W. (EIR)

18550 Man O'War Rd.

Eagle River, AK 99577-8335

Gold

Cherry Creek

Fortymile district

Tuluksak Dredging Ltd. (SWR)

1634 W 13th Ave.

Anchorage, AK 99501-4217

Gold

Spruce Creek

Aniak district

Turner, Wallace O. II, (EIR)

546 Wilcox Ave.

Fairbanks, AK 99709-3624

Gold

Moose Creek

Bonnifield district

Twogood, Dorothy (EIR)

PO Box 60203

Fairbanks, AK 99706-0203

Gold

Goldstream Creek

Fairbanks district
Twogood, Ron (EIR)

PO Box 60203

Fairbanks, AK 99706-0203

Gold

Goldstream Creek

Fairbanks district

Vander Wal, Jon (EIR)

E 171 Cranberry Creek Rd.

Shelton, WA 98584-7527

Gold

Marguerite Creek

Bonnifield district

Vetter, Adolph, Estate of (EIR) PO Box 70342

Fairbanks, AK 99707-0342

Gold

Gilmore Creek

Fairbanks district

Vetter, Adolph, Estate of (EIR)

PO Box 70342

Fairbanks, AK 99707-0342

Gold

Wolf Creek

Fairbanks district

Vetter, Rudolph (EIR)

PO Box 70342

Fairbanks, AK 99707-0342

Gold

Wolf Creek

Fairbanks district

Vial, D.B. (WR)

10508 Fawn Dr. NW

Gig Harbor, WA 98332-9510

Gold

Candle Creek

Fairhaven district

Vial, Michael L. (WR)

PO Box 292

Willow, AK 99688-0292

Gold

Candle Creek

Fairhaven district

Vogler, Joseph E., Estate of

(EIR)

PO Box 70040

Fairbanks, AK 99707-0040

Gold

Ketchum Creek

Circle district

Vogler, Lynn (EIR)

PO Box 70040

Fairbanks, AK 99707-0040

Gold

Ketchum Creek

Circle district

Vogt, Ray A. (EIR)

4200 Old Elliott Hwy

Unit 8 Box 10

Fairbanks, AK 99712-1073

Gold

Dome Creek

Fairbanks district
Vournas, George (SCR)

c/o Philip Brandl

14251 Sabine St.

Anchorage, AK 99516-3912

Gold

Cache Creek

Yentna district

Vournas, George (SCR)

c/o Philip Brandl

14251 Sabine St.

Anchorage, AK 99516-3912

Gold

Cache Creek

Yentna district

Vournas, George (SCR)

c/o Philip Brandl

14251 Sabine St.

Anchorage, AK 99516-3912

Gold

Cache Creek

Yentna district

Walsh, Daniel P. (WR)

PO Box 61098

Fairbanks, AK 99706-1098

Gold

Dexter Creek

Nome district

Walsh, Daniel P. (WR)

PO Box 61098

Fairbanks, AK 99706-1098

Gold

Dry Creek

Nome district

Walsh, Paul (WR)

PO Box 61098

Fairbanks, AK 99706-1098

Gold

Dexter Creek

Nome district

Walsh, Paul (WR)

PO Box 61098

Fairbanks, AK 99706-1098

Gold

Dry Creek

Nome district

Watts, Donald L. (EIR)

PO Box 81515

College, AK 99708-1515

Gold

Grubstake Creek

Bonnifield district

Weathers, Douglas L. (SCR)

PO Box 8082

Nikiski, AK 99635-8082

Gold

Cache Creek

Yentna district

Weathers, Edith (SCR)

PO Box 8082

Nikiski, AK 99635-8082

Gold

Cache Creek

Yentna district 
Whitten III, Fred J. (NR)

269 Madcap Ln.

Fairbanks, AK 99709-6568

Gold

Mailbox Creek

Koyukuk district

Whitten, Fred J. Jr., (NR)

269 Madcap Ln.

Fairbanks, AK 99709-6568

Gold

Mailbox Creek

Koyukuk district

Wicken, James T. (NR)

1709 Central Ave.

Fairbanks, AK 99709-4220

Gold

Gold Creek

Koyukuk district

Wigger, Walter P. (EIR)

PO Box 70078

Fairbanks, AK 99707-0078

Gold

Ester Creek

Fairbanks district

Wiggers, Dan Sr., Estate of (NR)

HC 30 Box 5382

Wasilla, AK 99654-9712

Gold

Hammond River

Koyukuk district

Wiggers, Dean R. (NR)

PO Box 870224

Wasilla, AK 99687-0224

Gold

Hammond River

Koyukuk district

Wilder, Karen (EIR)

107 7th Ave. \#2

Fairbanks, AK 99701-5063

Gold

Little Boulder Creek

Hot Springs district

Wilder, Richard (EIR)

107 7th Ave. \#2

Fairbanks, AK 99701-5063

Gold

Little Boulder Creek

Hot Springs district

Wilkinson, Fred D. (EIR)

PO Box 72702

Fairbanks, AK 99707-2702

Gold

Ketchum Creek

Circle district
Wilkinson, Fred D. (EIR)

PO Box 72702

Fairbanks, AK 99707-2702

Gold

Porcupine Creek

Circle district

Willard, Gerald L. (SCR)

PO Box 875532

Wasilla, AK 99687-5532

Gold

Bear Creek

Hope district

Willford, Frank E. (EIR)

PO Box 487

Cocolalla, ID 83813-0487

Gold

Woodchopper Creek

Hot Springs district

Williams, Michael A. (EIR)

PO Box 603

Tok, AK 99780-0603

Gold

Kenyon Creek

Fortymile district

Wolf, Ray D. (EIR)

30033 Redwood Hwy.

Cave Junction, OR 97523-9360

Gold

Harrison Creek

Circle district

Wolff, Flint (EIR)

PO Box 56331

North Pole, AK 99705-1331

Gold

Walker Fork

Fortymile district

Wolff, Margaret (EIR)

PO Box 56331

North Pole, AK 99705-1331

Gold

Walker Fork

Fortymile district

Wolff, Timber (EIR)

Box Bya Boundary

Tok, AK 99780

Gold

Walker Fork

Fortymile district

Wolters, Morris (EIR)

622-E, SR 4

Cathlamet, WA 98612

Gold

Crooked Creek

Circle district
Wood, James L. (EIR)

13302 Half S Bridge Ave.

Yuma, AZ 85365-9772

Gold

Little Boulder Creek

Hot Springs district

Wrede, Ronald J. (EIR)

2116 NE 80th St.

Seattle, WA 98115-4538

Gold

Switch Creek

Circle district

Wright Jr., Robert P. (EIR)

PO Box 60783

Fairbanks, AK 99706-0783

Gold

Last Chance Creek

Fairbanks district

Wright, Richard L. (NR)

3910 Tilleson Way

North Pole, AK 99705-6555

Gold

Gold Creek

Koyukuk district

Wright, Richard L. (NR)

3910 Tilleson Way

North Pole, AK 99705-6555

Gold

Gold Creek

Koyukuk district

Wyrick, L.E. (SWR)

PO Box 782

Willow, AK 99688-0782

Gold

Granite Creek

Aniak district

Wyrick, Marilyn A. (SWR)

PO Box 782

Willow, AK 99688-0782

Gold

Granite Creek

Aniak district

Yellow Eagle Mining, Inc.

(EIR)

PO Box 80566

Fairbanks, AK 99708

Gold

Ester Creek

Fairbanks district

Yoder, Dale E. (EIR)

PO Box 70529

Fairbanks, AK 99709-0529

Gold

Goldstream Creek

Fairbanks district
Yoder, Darlene (EIR)

PO Box 70529

Fairbanks, AK 99709-0529

Gold

Goldstream Creek

Fairbanks district

Yoder, Paul (EIR)

PO Box 70529

Fairbanks, AK 99709-0529

Gold

Goldstream Creek

Fairbanks district

Young, Edward J. (EIR)

1303 W 33rd Ave. Ste. 200

Anchorage, AK 99503-3634

Gold

Specimen Creek

Delta River district

Zimmer, George W. (SCR)

PO Box 572

Cooper Landing, AK 99572 0572

Gold

Quartz Creek

Seward district

Zimmer, Lillian L. (SCR)

PO Box 572

Cooper Landing, AK 99572 0572

Gold

Quartz Creek

Seward district

Zimmerman, Charles J. (EIR)

PO Box 41

Manley Hot Springs, AK 99756

Gold

Killarney Creek

Hot Springs district 


\section{APPENDIX D}

\section{Selected significant mineral deposits and mineral districts in Alaska ${ }^{a}$}

The alphabetized list of mineral deposits and mineral districts is keyed to the list of explanatory paragraphs that follow. For example, The Lik deposit in the alphabetized list is "Lik, 1, (fig. D-1)." This says that the location of Lik is shown as number 1 in figure D-1.

Alaska-Juneau, 100, (fig. D-3). Anderson Mountain, 54, (fig. D-1). Aniak district, 84, (fig D-3). Apex-EI Nido, 104. (fig. D-3). Apollo-Sitka mines, 86, (fig. D-3). Arctic, 9, (fig. D-1).

Avan Hills, 12, (Fig. D-3).

Baultoff, 75, (fig. D-2).

Bear Mountain, 21, (fig. D-2).

Big Creek/Ladue, 58, (fig. D-1).

Big Hurrah, 32. (fig. D-3).

Binocular and other prospects, 72 . (fig. D-1).

Bohemia Basin, 103, (fig. D-3).

Bokan Mountain, 122, (fig. D-3).

Bonanza Creek, 45, (fig. D-2).

Bond Creek, 73, (fig. D-2).

Bonnifield district massive sulfide deposits, 54, (fig. D-1).

Bornite, 8, (fig. D-1).

Brady Glacier, 98, (fig. D-3).

BT, 54, (fig. D-1).

Buck Creek, 23, (fig. D-2),

Calder Mine, 133, (fig D-2).

Cape Creek, 22, (fig. D-2).

Carl Creek, 74, (fig. D-2).

Casca VABM, 53, (fig. D-1).

Castle Island, 111, (fig. D-1).

Chandalar mining district, 17, (fig. D-3).

Chichagof, 101, (fig. D-3).

Chistochina, 68, (figs. D-2, D-3).

Circle mining district, 52, (fig. D-3).

Claim Point, 82, (fig. D-3).

Coal Creek, 63, (fig. D-2).

Copper City, 119, (fig. D-1).

Cornwallis Peninsula, 110, (fig. D-1).

Council mining district, 33, (fig. D-3).

Delta massive sulfide belt, 55 , (fig. D-1).

Denali prospect, 67, (fig. D-1).

Dolphin, 49e, (fig. D-3).

Donlin Creek, 137, (fig. D-3).

Drenchwater, 3, (fig. D-1).

Dry Creek, 54, (fig. D-1).

Eagle Creek, 34, (fig. D-3).

Ear Mountain, 25, (fig. D-2).

Ellamar, 78, (fig. D-1).

Ernie Lake (Ann Creek), 15, (fig. D-1).

Esotuk Glacier, 20, (fig. D-2).

Fairbanks mining district, 49, (fig. D-3).

Fairhaven/Inmachuk district, 39, (fig. D-3).

Fort Knox, 49a, (fig. D-3).

Fortymile mining district, 60, (fig. D-3).

Frost, 7a, (fig. D-1)

Funter Bay mining district, 99, (fig. D-3).

Galena Creek, 21a, (fig. D-1).

Gil Claims, 49f, (fig. D-3).

Ginny Creek, 4, (fig. D-1).
Golden Zone mine, 64. (figs, D-1, D-3). Goodnews Bay, 85, (fig. D-3).

Grant Mine, 49c, (fig. D-3).

Greens Creek, 105, (fig. D-1).

Groundhog Basin, 112, (fig. D-1).

Haines Barite/Palmer, 95, (fig. D-1).

Hannum, 27, (fig. D-1).

Hirst Chichagof, 101, (fig. D-3).

Horsfeld, 76, (fig. D-2).

Hot Springs mining district, 47.

(figs. D-2, D-3).

Hyder mining district, 117, (figs, D-1, D-2).

Iditarod district, 43, (fig. D-3).

Illinois Creek, 132, (figs, D-1, D-3).

Independence, 79, (fig. D-3).

Independence Creek, 28, (fig. D-1).

Inmachuk River, 39, (fig. D-3).

Innoko-Tolstoi mining district, 44. (fig. D-3).

Ivanof, 88 , (fig. D-2),

Jimmy Lake, 94, (fig. D-1).

Johnson River, 125, (fig. D-3).

Jualin, 128, (fig. D-3).

Jumbo, 118, (fig. D-1).

Kaiyah, 138, (fig. D-3).

Kantishna mining district, 61, (fig. D-3).

Kasaan Peninsula, 114. (fig. D-1).

Kasna Creek, 92, (fig. D-1).

Kemuk Mountain, 123, (fig, D-3).

Kennecott deposits, 71, (fig. D-1).

Kensington, 127, (fig, D-3).

Kivliktort Mountain, 5a, (fig. D-1).

Klery Creek, 14, (fig. D-3).

Klukwan, 96, (fig. D-3).

Kougarok Mountain, 26, (fig, D-2).

Koyukuk-Hughes mining district, 42 , (fig. D-3).

Koyukuk-Nolan mining district, 16 , (fig. D-3).

Latouche, Beatson, 80, (fig. D-1).

Liberty Belle, 54, (fig. D-1).

Lik. 1, (fig. D-1).

Livengood-Tolovana mining district, 48 , (fig. D-3).

Lost River, 24, (fig. D-2).

Lucky Shot, 79, (fig. D-3).

McLeod, 124, (fig. D-2).

Mertie Lode, 99, (fig. D-3).

Midas mine, 77. (fig. D-1).

Mike deposit, 90, (fig. D-2).

Mirror Harbor, 102, (fig. D-3).

Misheguk Mountain, 13, (fig. D-3).

Mosquito, Peternie, 56, (fig. D-2).

Mt. Prindle, 50, (fig. D-3).

Nabesna mine, 69, (fig. D-3).

Niblack, 121, (fig. D-1).

Nim prospect, 65 , (fig. D-1).
Nimiuktuk River, 126, (fig. D-1).

Nixon Fork, 135, (fig. D-3).

Nome mining district, 30, (fig. D-3).

Nunatak, 97, (fig. D-2).

Omalik, 35, (fig. D-1).

Omar, 7, (fig. D-1).

Orange Hill, 73, (fig. D-2).

Pebble Copper, 129, (fig. D-1).

Placer River, 38, (fig. D-2).

Pleasant Creek, 53, (fig, D-1).

Pogo, 130, (fig. D-3).

Poovookpuk Mountain, 40, (fig. D-2).

Porcupine Lake, 18, (fig. D-2).

Purcell Mountain, 41, (fig. D-2).

Pyramid, 87, (fig. D-2).

Quartz Creek, 37, (fig. D-1).

Quartz Hill, 120, (fig. D-2).

Red Bluff Bay, 109, (fig. D-3).

Red Devil, 83, (fig. D-3).

Red Dog, 2, (fig. D-1).

Red Mountain, 82, (fig. D-3).

Rex deposit, 91, (fig. D-2).

Rock Creek, 31, (fig. D-3).

Rua Cove, 81, (fig. D-1).

Ruby mining district, 46, (fig. D-3).

Ryan Lode, 49b, (fig. D-3).

Salt Chuck, 115, (fig. D-3),

Sheep Creek, 54, (fig. D-1).

Shotgun Hills, 131, (fig. D-3).

Sinuk River region, 29, (fig. D-1).

Slate Creek, 59, (fig. D-3).

Sleitat Mountain, 93, (fig. D-2).

Smucker, 11, (fig. D-1).

Snettisham, 107. (fig. D-3).

Snipe Bay, 113, (fig. D-3).

Solomon mining district, 33, (fig. D-3).

Spirit Mountain, 70, (fig. D-3).

Stampede mine, 62, (fig. D-3).

Story Creek, 5, (fig. D-1).

Sumdum, 106, (fig. D-1).

Sun, 10, (fig. D-1).

Taurus, 57, (fig. D-2),

Three Castle Mountain, 53, (fig. D-1).

Tracy Arm, 108, (fig. D-1).

True North, 49d, (fig. D-3).

Twin Mountain, 51, (fig. D-2).

Union Bay, 116, (fig. D-3).

Valdez Creek district, 66, (fig. D-3).

Vinasale Mountain, 134, (fig. D-3).

Virginia Creek, 54, (fig. D-1).

Von Frank Mountain, 136, (fig, D-3).

War Baby, 79, (fig. D-3).

Weasel Mountain, Bee Creek, 89. (fig. D-2).

Whoopee Creek, 6, (fig. D-1).

Willow Creek, 79, (fig. D-3).

Wind River, 19, (fig. D-1).

Windy Creek, 36, (fig. D-2).

Zackly, 67a, (fig. D-1).

This generalized summary does not describe all of the known 6,400 mineral deposits in Alaska.

NOTE: In cooperation with DGGS and the Russian Academy of Sciences, the USGS published Open-File Report 93-339 (Nokleberg and others, 1993), Metallogenesis of mainland Alaska and the Russian northeast, which describes 273 lode deposits and 43 significant placer districts in Alaska. 


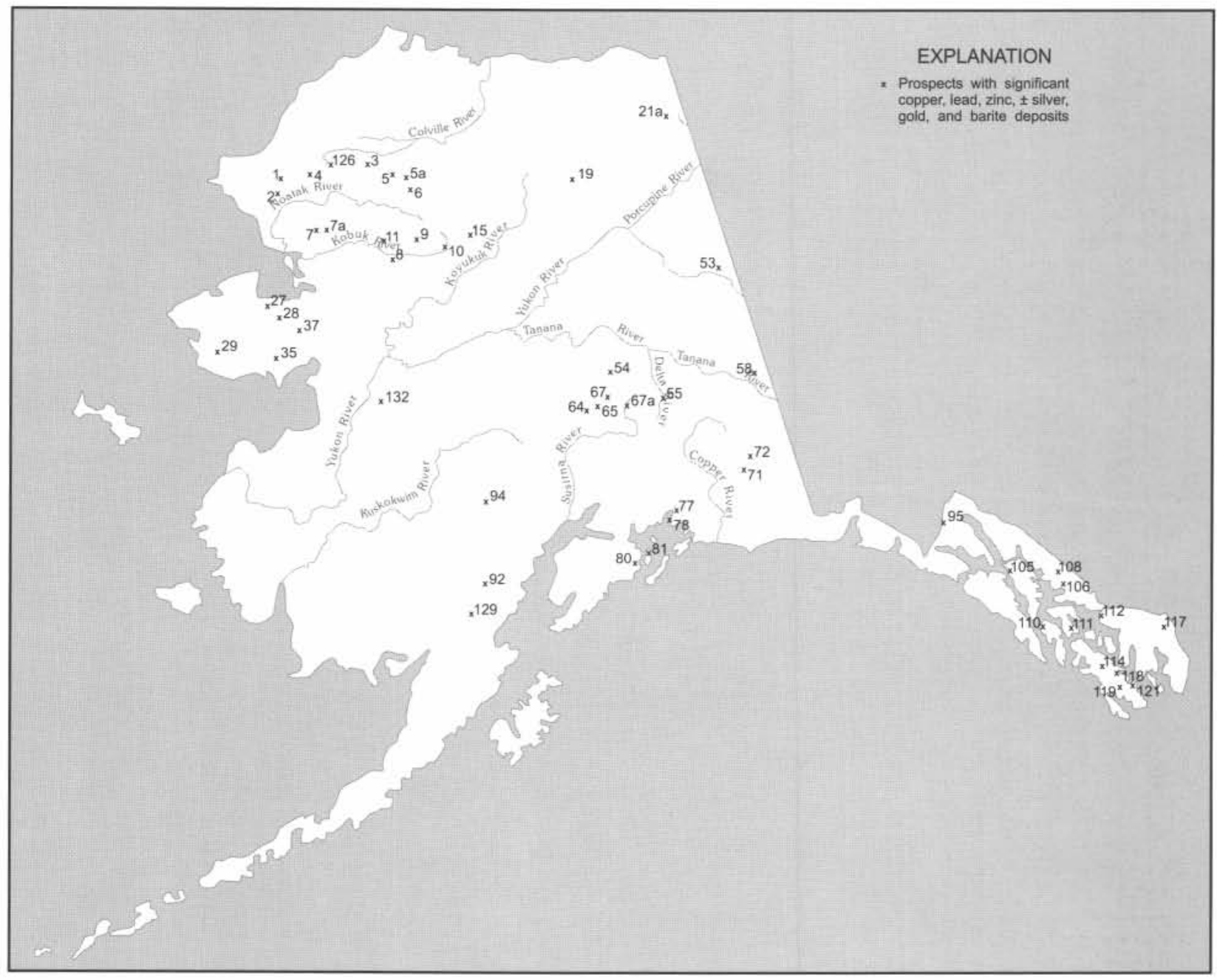

Figure D-1. Significant copper, lead, zinc with credits of silver, gold, and barite deposits in Alaska, 1999.

Map no,

1 Lik-Major stratabound massive sulfide $(\mathrm{Zn}-\mathrm{Pb}-\mathrm{Ag}-$ $\mathrm{Ba})$ deposit in black shale and chert. Proven reserve (Lik) estimate of 24 million tons of $9 \% \mathrm{Zn}, 3.1 \% \mathrm{~Pb}$, and $1.4 \mathrm{oz} /$ ton $\mathrm{Ag}$ (fig. D-1).

2 Red Dog - At least three major stratabound massive sulfide deposits hosted in Pennsylvanian or Mississippian shale; similar to locality 1. (a) The Main deposit at Red Dog contains 52.5 million tons of measured and indicated ore grading $19.2 \% \mathrm{Zn}, 5.2 \% \mathrm{~Pb}$, with $3.2 \mathrm{oz}$ ton $\mathrm{Ag}$. (b) The Aqqaluk deposit contains 80.4 million tons grading $13.6 \% \mathrm{Zn}, 3.7 \% \mathrm{~Pb}$, and $2.1 \mathrm{oz}$ ton $\mathrm{Ag}$. (c) The Hilltop deposit with an indicated reserve is 10.6 million tons grading $17.8 \% \mathrm{Zn}, 5.5 \% \mathrm{~Pb}$, and $3.8 \mathrm{oz} /$ ton Ag. (d) Inferred resource in the Paalaaq deposit is 14.3 million tons of $15.0 \% \mathrm{Zn}, 4.0 \% \mathrm{~Pb}$, and $2.9 \mathrm{oz} /$ ton $\mathrm{Ag}$. (e) Anarraq deposit discovered in 1999 (fig. D-1).

3 Drenchwater-Mississippian and Pennsylvanian shales and cherts contain three stratabound base metal occurrences spatially related to acid volcanics. The lowest unit, a siliceous mudstone, contains a $2 \mathrm{ft}$ layer with up to $23 \% \mathrm{Zn}$. An overlying gray chert contains up to $11 \% \mathrm{Zn}$ and up to $5 \% \mathrm{~Pb}$ with some $\mathrm{Ag}$ in fracture fillings. At the top of the overlying tuffaceous layer, Agbearing $\mathrm{Zn}$ and $\mathrm{Pb}$ mineralization outcrops discontinuously for at least $6.500 \mathrm{ft}$, and contains up to $26 \% \mathrm{Zn}$ and $51 \% \mathrm{~Pb}$ in grab samples (fig. D-1).

4 Ginny Creek - Epigenetic, disseminated $\mathrm{Zn}-\mathrm{Pb}-\mathrm{Ag}$ deposits with barite in sandstone and shale of Noatak Sandstone of Late Devonian through Early Mississippian age. Random grab samples of surface float contain $0.3 \%$ to $3.0 \% \mathrm{Zn}$ and highly variable amounts of $\mathrm{Pb}$ and $\mathrm{Ag}$ (fig. D-1).

5 Story Creek - Epigenetic replacement deposits of $\mathrm{Zn}$ $\mathrm{Pb}-\mathrm{Ag}-\mathrm{Cu}-\mathrm{Au}$ hosted in brecciated zones in Devonian Kanayut Conglomerate or Lower Mississippian Kayak Shale. Grab samples of high-grade material contain up to $0.43 \% \mathrm{Cu}, 34 \% \mathrm{~Pb}, 28.8 \% \mathrm{Zn}, 0.04 \mathrm{oz}$ ton $\mathrm{Au}$, and 30 oz/ton Ag (fig. D-1).

5a Kivliktort Mountain - Mineralized float is widespread on the north flanks of the mountain, apparently spatially related to the contact between shales at the base of the 


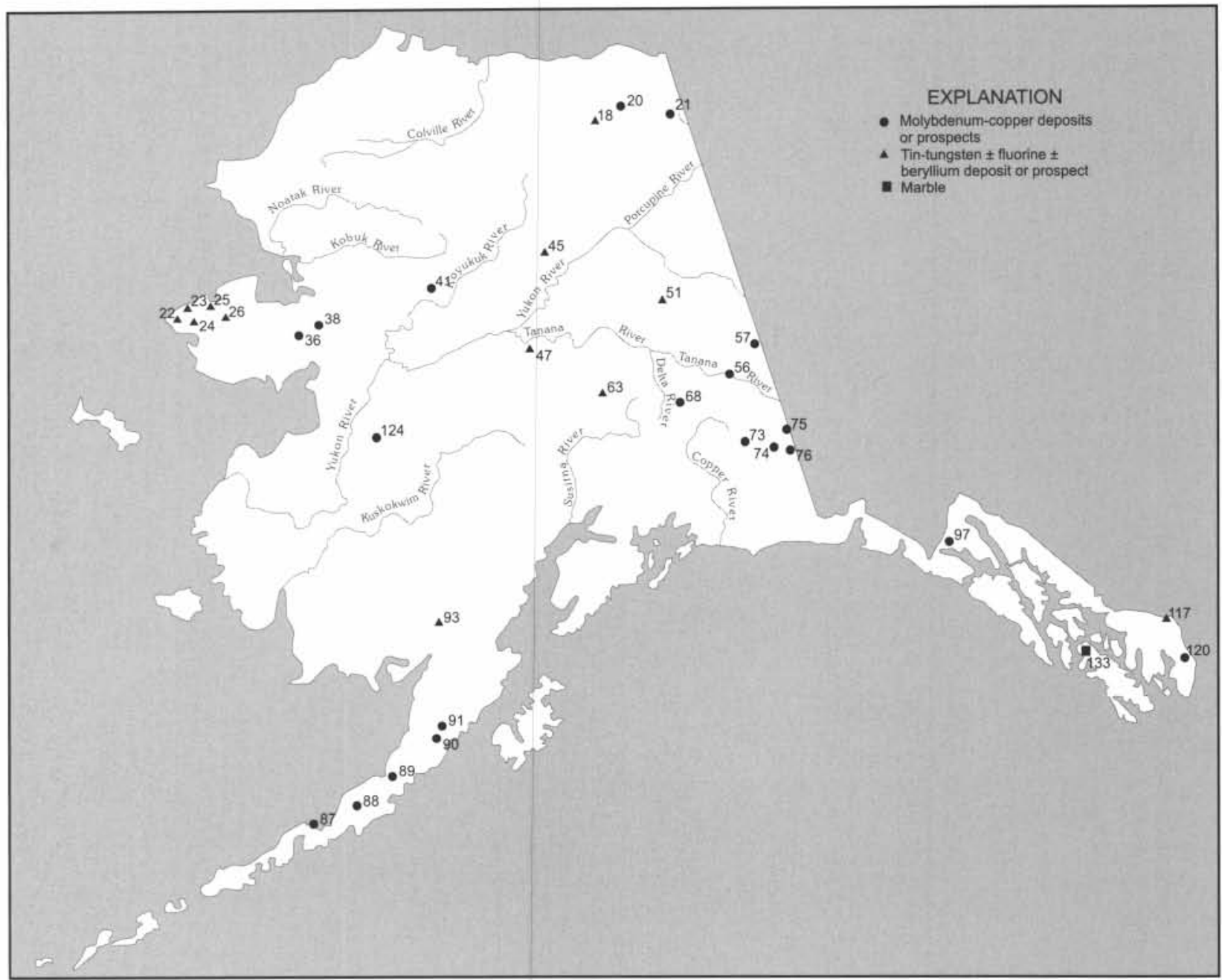

Figure D-2. Significant molybdenum-copper and tin-tungsten with credits of fluorite and beryllium deposits in Alaska, 1999.

hills and coarse-grained siliceous clastic rocks on the upper slopes. Rock samples containing up to $30 \% \mathrm{Zn}$ have been reported (fig. D-1).

6 Whoopee Creek-Epigenetic replacement deposits of $\mathrm{Zn}-\mathrm{Pb}-\mathrm{Cu}-\mathrm{Ag}-\mathrm{Au}-\mathrm{Cd}$ in breccia zones in Devonian Kanayut Conglomerate or Lower Mississippian Kayak Shale. Random grab samples of mineralized material contain $0.24 \% \mathrm{Cu}, 0.37 \% \mathrm{Cd}, 46 \% \mathrm{Zn}, 44 \% \mathrm{~Pb}, 0.14 \mathrm{oz}$ ton $\mathrm{Au}$, and $14.8 \mathrm{oz} /$ ton $\mathrm{Ag}$ (fig. D-1).

7 Omar-Epigenetic replacement deposits of Paleozoic age; include bedded barite occurrences. Grab samples contain $15.3 \% \mathrm{Cu}, 0.15 \% \mathrm{~Pb}, 0.95 \% \mathrm{Zn}, 0.05 \% \mathrm{Co}$, and $0.3 \mathrm{oz} /$ ton Ag. BLM estimates 35 million tons of $4 \% \mathrm{Cu}$ (fig. D-1).

7a Frost-Possible 9 million tons of barite in pods, lenses, and wavy-banded quartz-calcite-barite veins. Chalcopyrite and galena occur in the veins which cross cut Paleozoic limestone and dolomite for a minimum distance of $1 \mathrm{mi}$. Selected samples contain up to $13.2 \%$ Zn (fig. D-1).
8 Bornite-Major stratabound $\mathrm{Cu}-\mathrm{Zn}$ deposit in brecciated carbonate rock of Devonian age; 5.0 million ton orebody contains $4.0 \% \mathrm{Cu}$ and accessory $\mathrm{Zn}$ and $\mathrm{Co}$. Larger reserve estimate of 40 million tons of about $2 \%$ $\mathrm{Cu}$ and undisclosed amount of $\mathrm{Zn}$ and $\mathrm{Co}$. At grade of $1.2 \% \mathrm{Cu}$, reserves are 100 million tons (fig. D-1).

9 Arctic-Major volcanogenic $(\mathrm{Cu}-\mathrm{Zn})$ massive sulfide deposit hosted in sequence of metarhyolite, metatuff, and graphitic schist of Devonian age; indicated reserves of 40 million tons grade $4.0 \% \mathrm{Cu}, 5.5 \% \mathrm{Zn}, 0.8 \% \mathrm{~Pb}, 1.6$ $\mathrm{oz} /$ ton $\mathrm{Ag}$, and $0.02 \mathrm{oz} /$ ton $\mathrm{Au}$ (fig. D-1).

$10 \mathrm{Sun}-$ Major $(\mathrm{Cu}-\mathrm{Pb}-\mathrm{Zn}-\mathrm{Ag})$ massive sulfide deposit in sequence of middle Paleozoic metarhyolite and metabasalt. Average grades are 1 to $4 \% \mathrm{~Pb}, 6$ to $12 \% \mathrm{Zn}$, 0.5 to $7 \% \mathrm{Cu}, 3$ to $11 \mathrm{oz} /$ ton $\mathrm{Ag}$ (fig. D-1).

11 Smucker-Middle Paleozoic volcanogenic massive sulfide deposit; $3,000 \mathrm{ft}$ long and up to $190 \mathrm{ft}$ wide; contains significant tonnage of $\mathrm{Cu}-\mathrm{Pb}-\mathrm{Zn}$ ore that grades $1.5 \% \mathrm{~Pb}, 5$ to $10 \% \mathrm{Zn}, 3$ to $10 \mathrm{oz}$ ton $\mathrm{Ag}$, with minor Au (fig. D-1). 


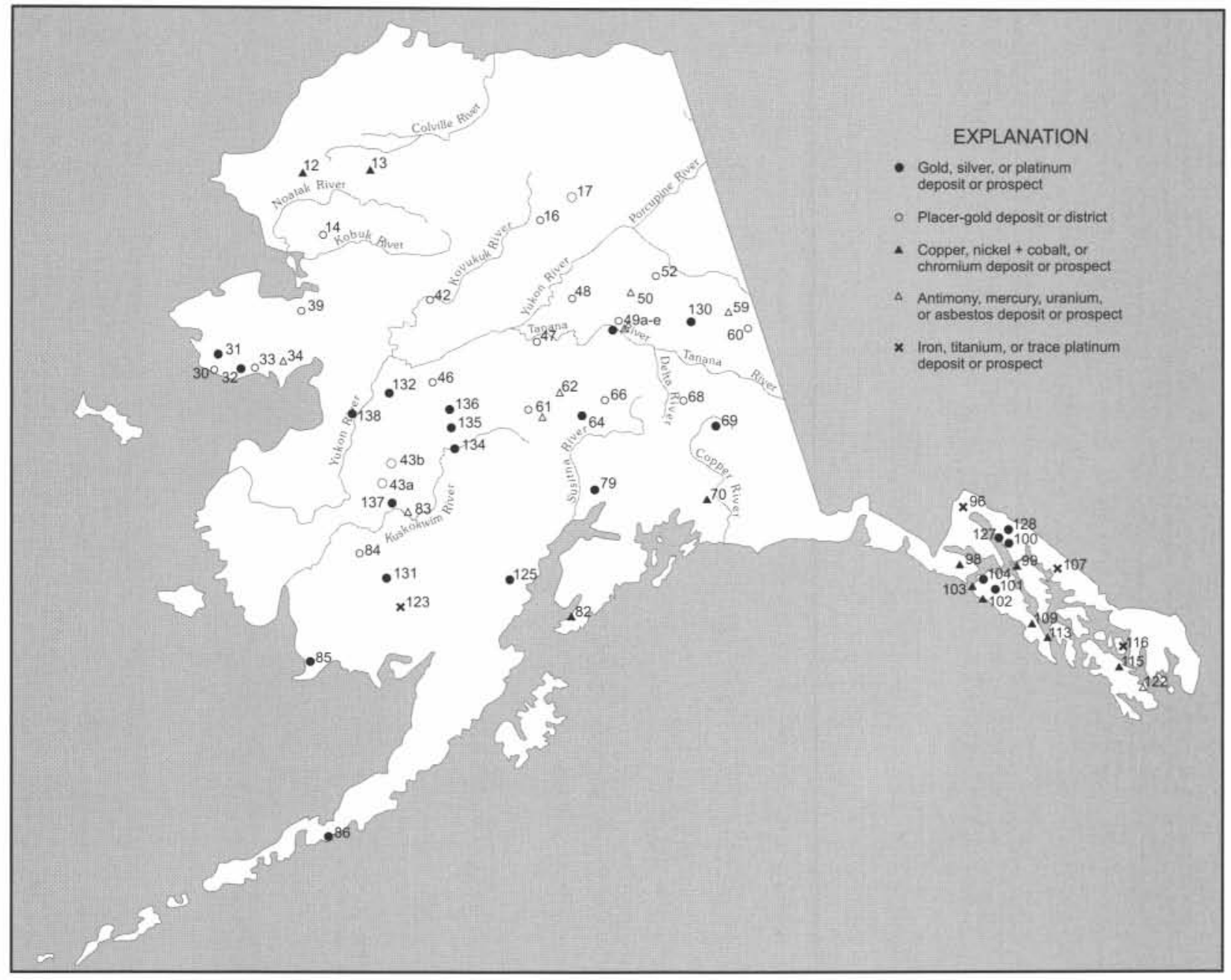

Figure D-3. Significant gold, silver, platinum, and strategic mineral deposits in Alaska, 1999.

12 Avan Hills - Disseminated chromite in layered ultramafic rocks; grab samples contain up to $4.3 \% \mathrm{Cr}$ with $0.015 \mathrm{oz} /$ ton PGM (fig. D-3).

13 Misheguk Mountain - Chromite occurrences similar to those in Avan Hills (fig. D-3).

14 Klery Creek-Lode and placer Au deposits worked intermittently from 1909 through 1930 s. Total production through 1931, mostly from placer deposits, estimated at $31,320 \mathrm{oz} \mathrm{Au}$ (fig. D-3).

15 Ernie Lake (Ann Creek) - Stratabound massive sulfide occurrence in metarhyolite, metatuff, and marble. Gossan zones strongly anomalous in $\mathrm{Cu}-\mathrm{Pb}-\mathrm{Zn}$ and $\mathrm{Ag}$ (fig. D-1).

16 Koyukuk-Nolan mining district-Major placer $\mathrm{Au}$ district; from 1893 to 1999 produced an estimated $342,489 \mathrm{oz} \mathrm{Au}$. Gold placers in Nolan Creek mined on surface and underground, both sources of large gold nuggets. Significant deep placer reserves remain (fig. D-3).

17 Chandalar mining district-Major Au-producing district; substantial production in excess of $65,860 \mathrm{oz} \mathrm{Au}$ through 1999 from lode and placer sources; lode Au found in crosscutting quartz veins that intrude schist and greenstone. Active development of placer deposits and lodes in progress. Inferred lode reserves estimated to be 45,000 tons with grade of $2 \mathrm{oz}$ ton Au (fig. D-3).

18 Porcupine Lake - Stratiform fluorite occurrences and argentiferous enargite, tetrahedrite associated with felsic volcanic rocks of late Paleozoic age. Reported grades of up to $30 \%$ fluorite $\left(\mathrm{CaF}_{2}\right)$ reported, with grab samples of $4.8 \% \mathrm{Cu}$ (fig. D-2).

19 Wind River - Stratabound $\mathrm{Pb}-\mathrm{Zn}$ massive sulfide prospects; reported grades of up to $5 \% \mathrm{~Pb}$ (fig. D-1).

20 Esotuk Glacier-Disseminated Mo-Sn-W- $\mathrm{Pb}-\mathrm{Zn}$ mineralization in skarns associated with Devonian(?) schistose quartz monzonite. Grab samples contain up to $0.08 \% \mathrm{Sn}$ and $0.15 \% \mathrm{~W}$ (fig. D-2).

21 Bear Mountain-Major stockwork Mo-W-Sn occurrence in intrusive breccia. Rock samples containing up to $0.8 \%$ Mo and $0.6 \% \mathrm{~W}$ occur within a 35 -acre area where soil samples average more than $0.2 \% \mathrm{MoS}_{2}$, and an adjacent 25 -acre area where rubble contains 
wolframite has soils averaging greater than $0.12 \%$ $\mathrm{WO}_{3}$. Rubble crop in this area indicates a Tertiary porphyry system as the source of the Mo and $\mathrm{W}$ (fig. D-2).

21a Galena Creek - Steeply dipping veins contain up to $21 \% \mathrm{Cu}, 3.5 \% \mathrm{Zn}$, and $1.3 \% \mathrm{~Pb}$ with $5.5 \mathrm{oz}$ ton $\mathrm{Ag}$ on the east side of the creek, and on the ridge west of the creek a large area of disseminated mineralization and veinlets contains predominantly $\mathrm{Zn}$ (fig. D-1).

22 Cape Creek-Major placer Sn producer. More than 500 tons $\mathrm{Sn}$ produced from 1935 to 1941 ; from 1979 to 1990 , produced 1,040 tons Sn. Derived from Cape Mountain in contact zone of Cretaceous granite and limestone (fig. D-2).

23 Buck Creek-Major placer Sn producer. More than 1,100 tons Sn produced from 1902 to 1953 (fig. D-2).

24 Lost River-Major Sn, fluorite, W, and Be deposit associated with Cretaceous $\mathrm{Sn}$ granite system. More than 350 tons $\mathrm{Sn}$ produced from skarn and greisen lode sources. Measured reserves amount to 24.6 million tons that grade $0.15 \% \mathrm{Sn}, 16.3 \% \mathrm{CaF}_{2}$, and $0.03 \% \mathrm{WO}_{3}$, based on $45,000 \mathrm{ft}$ of diamond drilling (fig. D-2).

25 Ear Mountain - Placer $\mathrm{Sn}$ district and $\mathrm{Sn}-\mathrm{Cu}-\mathrm{Au}-\mathrm{Ag}-$ $\mathrm{Pb}-\mathrm{Zn}$ skarn mineralization of Cretaceous age. Area also anomalous in U (fig. D-2).

26 Kougarok Mountain - Sn deposit hosted in quartztourmaline-topaz greisen of Cretaceous age. Grades may average $0.5 \% \mathrm{Sn}$ and $0.01 \% \mathrm{Ta}$ and $\mathrm{Nb}$, but a high-grade resource of 150,000 tons grading $1 \%+\mathrm{Sn}$ has been identified, with incrementally higher tonnage at lower grades (fig. D-2).

27 Hannum - Stratiform, carbonate-hosted $\mathrm{Pb}-\mathrm{Zn}-\mathrm{Ag}$ massive sulfide deposit of mid-Paleozoic age in heavily oxidized zone that ranges from 30 to $150 \mathrm{ft}$ thick. Mineralized zone reported to assay up to $10 \% \mathrm{~Pb}, 2.2 \%$ $\mathrm{Zn}, 0.04 \mathrm{oz} /$ ton $\mathrm{Au}$, and $1.76 \mathrm{oz} /$ ton $\mathrm{Ag}$ (fig. D-1).

28 Independence $\mathrm{Creek}-\mathrm{Pb}-\mathrm{Zn}-\mathrm{Ag}$ massive sulfide deposit; high-grade ore shipped in 1921 contained $30 \%$ $\mathrm{Pb}, 5 \% \mathrm{Zn}$, up to $150 \mathrm{oz}$ ton $\mathrm{Ag}$. Mineralization restricted to shear zone in carbonates (fig. D-1).

29 Sinuk River region - Several $\mathrm{Pb}-\mathrm{Zn}-\mathrm{Ag}-\mathrm{Ba}-\mathrm{F}$ bearing massive sulfide deposits and layered $\mathrm{Fe}$ deposits in carbonate and metavolcanic rocks of Nome Group. Mineralized zones extend for over $8,000 \mathrm{ft}$ along strike (fig. D-1).

30 Nome mining district-Major placer Au producer. Production from $1897-1999$ in excess of 4,978,449 oz Au all from placers. Sporadic Sb and $\mathrm{W}$ production in past (fig. D-3).

31 Rock Creek - 750,000 oz Au resource, with about 10.2 million tons grading $0.074 \mathrm{oz} /$ ton $\mathrm{Au}$ in vein swarms and stringers in an area 1,500 ft long, $500 \mathrm{ft}$ maximum width and $300 \mathrm{ft}$ deep (fig. D-3).

32 Big Hurrah - Epigenetic vein deposit in black slate and metasedimentary rocks of the Soloman schist. Deposit contains some $\mathrm{W}$ mineralization and has produced over $27,000 \mathrm{oz}$ Au from nearly 50,000 tons milled ore. Proven, inferred, and indicated reserves total 104,000 tons that grade $0.61 \mathrm{oz} /$ ton $\mathrm{Au}, 0.55 \mathrm{oz} /$ ton $\mathrm{Ag}$, and credits of $\mathrm{WO}_{3}$ (fig. D-3).

33 Solomon and Council mining districts - Major placer Au districts; produced over 1,046,513 oz through 1999. Three structurally controlled Au deposits in Bluff areaDaniels Creek, Saddle, and Koyana Creek - contain minimum inferred reserves of 6.5 million tons grading $0.1 \mathrm{oz}$ ton Au (fig. D-3).

34 Eagle Creek-U prospect in Cretaceous Kachauik alkalic intrusive rocks. Highly anomalous geochemical values and $U$ concentrations of $1,000 \mathrm{ppm}$ reported (fig. D-3).

35 Omalik - Vein-type $\mathrm{Pb}-\mathrm{Zn}-\mathrm{Ag}$ massive sulfide prospect in Paleozoic carbonate rocks; from 1881 to 1900 , produced 400 tons of $\mathrm{Pb}-\mathrm{Zn}$ ore that averaged about $10 \% \mathrm{~Pb}$ and $40 \mathrm{oz}$ ton $\mathrm{Ag}$. Grades of oxidized $\mathrm{Zn}$ ore reported to be up to $34 \% \mathrm{Zn}$ (fig. D-1).

36 Windy Creek - Disseminated $\mathrm{Mo}-\mathrm{Pb}-\mathrm{Zn}$ mineralization in quartz veins and skarns with reported values as high as $0.15 \%$ Mo (fig. D-2).

37 Quartz Creek - Significant $\mathrm{Pb}-\mathrm{Zn}-\mathrm{Ag}$ mineralization; reported grades of $15 \%$ combined $\mathrm{Pb}-\mathrm{Zn}$ and $10 \mathrm{oz} /$ ton $\mathrm{Ag}$ (fig. D-1).

38 Placer River-Significant Mo-F mineralization disseminated in intrusive rocks. Reported values of $0.2 \%$ Mo (fig. D-2).

39 Fairhaven/Inmachuk district - Placer deposits with 348,079 oz production from 1902-1999; significant reserves remaining in a large ancestral channel system. Large base metal sulfide concentrations and $U$ values in concentrates (fig. D-3).

40 Poovookpuk Mountain - Porphyry Mo mineralization. Reported grades of up to $0.25 \%$ Mo (fig. D-2).

41 Purcell Mountain-Mo and Ag occurrences associated with Cretaceous alkalic igneous plutons, alaskite, and bostonite dikes (fig. D-2).

42 Koyukuk-Hughes mining district - Production of $245,188 \mathrm{oz}$ Au from 1930 to 1999 , mainly from Alaska Gold Co. dredge at Hogatza; dredge reactivated in 1981, but deactivated in 1984, and reactivated again in 1990. Nonfloat mechanized operation on Utopia Creek produced significant amount of placer Au from 1930 to 1962 (fig. D-3).

43 Iditarod district-Major placer Au district; produced $1,562,674 \mathrm{oz}$ Au through 1999. Significant reserves of lode $\mathrm{Au}$ and lode $\mathrm{W}$ at Golden Horn deposit Chicken Mountain, and other known lodes in region associated with shear zones and monzonite intrusive rocks of Late Cretaceous age (fig. D-3).

44 Innoko-Tolstoi mining district-Major placer $\mathrm{Au}$ district with significant lode $\mathrm{Au}-\mathrm{Sb}-\mathrm{Hg}$ potential; lode sources for placers are Late Cretaceous volcanic- 
plutonic complexes and dike swarms that intrude Mesozoic flysch; mining district produced $723,290 \mathrm{oz}$ Au through 1999, almost all from placer deposits (fig. D-3).

45 Bonanza Creek - Skarn-type W mineralization along intrusive contact; no published information available (fig. D-2).

46 Ruby mining district-Placer $\mathrm{Au}-\mathrm{Sn}$ district; produced more than 477,171 oz Au from 1931 to 1999 ; mining district also contains $\mathrm{Pb}-\mathrm{Ag}$ prospects with grades reportedly as high as $82 \mathrm{oz} /$ ton $\mathrm{Ag}$ (fig. D-3).

47 Hot Springs mining district-Placer $\mathrm{Au}-\mathrm{Sn}$ district; produced more than $576,082 \mathrm{oz} \mathrm{Au}$ and over $720,000 \mathrm{lb}$ cassiterite through 1999. Includes Eureka and Tofty subdistricts (figs. D-2, D-3).

48 Livengood-Tolovana mining district - Placer $\mathrm{Au}$ district; produced more than $527,978 \mathrm{oz}$ Au since discovery in 1914 to 1999 . Substantial reserves remain mainly on Livengood Bench, a Pliocene ancestral channel (fig. D-3).

49 Fairbanks mining district - Nationally ranked $\mathrm{Au}$ producing district; largest producer in Alaska. Produced about 8,145,550 oz Au from placer deposits (19021999). Major lode Au and lode Sb producer; produced more than $304,548 \mathrm{oz}$ Au and over 4 million lb Sb from. veins and shear zones through 1990. Production of W exceeded 4,000 short ton units since 1915, all derived from skarn near Cretaceous quartz monzonite (fig. D-3).

49a Fort Knox - Disseminated Au deposit within granodiorite/quartz monzonite pluton near Fairbanks. Proven and probable reserves as of December 31, 1999, open at depth, are 2,968,000 oz of Au in 123.31 million tons of rock at an average Au grade of $0.024 \mathrm{oz} /$ ton. Possible reserves of 7.78 million tons at an average grade of $0.023 \mathrm{oz} /$ ton $\mathrm{Au}(176,000 \mathrm{oz}$ of $\mathrm{Au})$ and a resource of 63.71 million tons at an average grade of $0.0225 \mathrm{oz} /$ ton $\mathrm{Au}(1,422,000 \mathrm{oz}$ of $\mathrm{Au})$. The total gold resource at Fort Knox is 4.57 million oz of Au. Fairbanks Gold Mining Inc. mined $702,295 \mathrm{oz}$ in 1996,1997 , and 1998 at a cash cost of $\$ 170 /$ oz to $\$ 189 / \mathrm{oz}$ (fig. D-3).

49b Ryan Lode-Based on a $0.015 \mathrm{oz} /$ ton cutoff, total reserves in the metasediment-hosted Ryan Lode and subparallel igneous-hosted Curlew Shear are $822,200 \mathrm{oz}$ of $\mathrm{Au}$ in 14.6 million tons of rock. A geologic resource of about 2.4 million oz occurs within the total shear zone system (fig. D-3),

49c Grant Mine - A series of subparallel Au-bearing quartz veins in the schist and quartzite of Ester Dome based on exploration in 1990. Indicated reserves on one vein system, the O'Dea, are 212,000 tons of $0.36 \mathrm{oz} /$ ton Au. Other similar vein systems have been identified within the property (fig. D-3).

49d True North-Au occurs in siderite-quartz veins in carbonaceous quartzite and schist within a terrane containing eclogitic rocks. The mineral inventory is 18.2 million tons grading $0.072 \mathrm{oz} /$ ton Au for a contained 1,314,000 oz Au. Further exploration is expected to increase the reserve base (fig. D-3). 49e Dolphin-Recently recognized mineralized intermediate intrusion contains anomalous $\mathrm{Au}, \mathrm{As}, \mathrm{Bi}$ and $\mathrm{Sb}$. Discovery hole in 1995 intercepted $330 \mathrm{ft}$ of $0.049 \mathrm{oz}$ ton Au (fig. D-3).

$49 \mathrm{f}$ Gil Claims - Gold occurs in two calc-silicate zones within Paleozoic schist units. Gold enrichment occurs along iron-stained shears and within quartz-calcite veinlets. Drilling has identified an in-place Au resource of $433,000 \mathrm{oz}$ at an average grade of $0.04 \mathrm{oz} /$ ton $\mathrm{Au}$ (fig. D-3).

50 Mt. Prindle - Significant U-rare-earth mineralization in Mesozoic alkaline igneous rocks. Rock geochemical values of up to $0.7 \% \mathrm{U}$; up to $15 \%$ rare-earth elements reported (fig. D-3).

51 Twin Mountain - Significant W mineralization associated with skarn development along contact zone of quartz monzonite stock of Cretaceous age (fig. D-2).

52 Circle mining district - Currently one of Alaska's largest producing placer Au districts; produced $1,049,157 \mathrm{oz}$ Au since discovery in 1893 to 1999 . Has significant potential for $\mathrm{Sn}, \mathrm{W}$, and Au mineralization from variety of lode sources (fig. D-3).

53 Three Castle Mountain, Pleasant Creek, Casca VABM - Stratabound $\mathrm{Pb}-\mathrm{Zn}$ massive sulfide mineralization. Reported grades of up to $17 \% \mathrm{Zn}$ and $2 \% \mathrm{~Pb}$ (fig. D-1).

54 Bonnifield district massive sulfide deposits (Anderson Mountain, Dry Creek, Sheep Creek, Virginia Creek, BT, Liberty Belle) - Significant volcanogenic $\mathrm{Cu}-\mathrm{Pb}-$ $\mathrm{Zn}-\mathrm{Ag}$ massive sulfide deposits of Devonian to Mississippian age in Bonnifield mining district. Potential for high-grade deposits reported. Includes Liberty Belle stratabound $\mathrm{Au}-\mathrm{B}$ deposit and mineralization in Sheep Creek; latter contains $\mathrm{Sn}$ as well as base metals (fig. D-1).

55 Delta massive sulfide belt - Contains at least 30 known volcanogenic massive sulfide deposits and occurrences. Grades from 0.3 to $1.1 \% \mathrm{Cu}, 1.7$ to $5.7 \% \mathrm{Zn}, 0.5$ to $2.3 \% \mathrm{~Pb}, 0.7$ to $2.0 \mathrm{oz} /$ ton $\mathrm{Ag}$, and 0.018 to $0.061 \mathrm{oz} /$ ton $\mathrm{Au}$; estimated potential reserve of 40 million tons for all deposits. Recent exploration has identified several gold prospects associated with silicified structures in the White Gold trend (fig. D-1).

56 Mosquito, Peternie - Porphyry Mo prospects of early Tertiary age; reported grades of up to $0.17 \%$ Mo (fig. D-2).

57 Taurus - Significant major porphyry $\mathrm{Cu}-\mathrm{Au}$ prospect of Paleocene age. East Taurus Zone contains inferred reserves of 140 million tons grading about $0.30 \% \mathrm{Cu}$ and $0.01 \mathrm{oz} /$ ton $\mathrm{Au}$, and $0.03 \%$ Mo (fig. D-2).

58 Big Creek/Ladue - Stratabound $\mathrm{Pb}-\mathrm{Zn}-\mathrm{Ag}$ massive sulfide prospects in metavolcanic rocks (fig. D-1).

59 Slate Creek-At least 55 million tons of $6.3 \%$, highquality chrysotile asbestos in serpentinized ultramafic rocks of Permian(?) age (fig. D-3).

60 Fortymile mining district-Major placer Au district. Produced over $542,396 \mathrm{oz}$ placer and very minor lode Au since discovery in 1883 to 1999 , the longest 
continuous production of $\mathrm{Au}$ (113 years) of any Alaskan mining district (fig. D-3).

61 Kantishna mining district-Major placer Au and lode $\mathrm{Ag}-\mathrm{Au}-\mathrm{Pb}-\mathrm{Zn}-\mathrm{Sb}-\mathrm{W}$ district. Produced 99,307 oz placer and lode $\mathrm{Au}$, about $307,000 \mathrm{oz}$ lode $\mathrm{Ag}$, and 5 million lb Sb from shear zones and vein deposits hosted in metamorphic units of Yukon-Tanana terrane. Nearly 90 lode deposits have been identified; potential exists for significant $\mathrm{Ag}-\mathrm{Au}-\mathrm{Pb}-\mathrm{Zn}$ resources. Metalliferous stratabound base metal deposits occur in schist and quartzite (fig. D-3).

62 Stampede mine-Major Sb deposit; produced more than 3.5 million $\mathrm{lb}$ Sb from large shear zone in polymetamorphic rocks of Yukon-Tanana terrane (fig. D-3).

63 Coal Creek - Greisen-hosted $\mathrm{Sn}-\mathrm{Cu}-\mathrm{W}$ deposit in "McKinley" age pluton (55 million years old). Reported reserves of 5 million tons of ore that grade $0.28 \% \mathrm{Sn}$ and $0.3 \% \mathrm{Cu}$ with credits of $\mathrm{W}, \mathrm{Ag}$, and $\mathrm{Zn}$ (fig. D-2).

64 Golden Zone mine-Major $\mathrm{Au}-\mathrm{Cu}-\mathrm{Ag}$ deposits in Late Cretaceous breccia pipe and skarn deposits. Produced more than $1,581 \mathrm{oz} \mathrm{Au}, 8,617 \mathrm{oz} \mathrm{Ag}$, and $42,000 \mathrm{lb} \mathrm{Cu}$. On the basis of recent (1994) drilling, the Pipe, Bunkhouse, and Copper King deposits contain 13.3 million tons grading $0.095 \mathrm{oz}$ ton Au (figs. D-1 and D-3).

$65 \mathrm{Nim}$ Prospect-Porphyry $\mathrm{Cu}-\mathrm{Ag}-\mathrm{Au}$ deposit of Late Cretaceous age. Reported grades of up to $5.0 \% \mathrm{Cu}$ and $9 \mathrm{oz}$ ton $\mathrm{Ag}$ (fig. D-1).

66 Valdez Creek district-About $508,554 \mathrm{oz}$ Au production through 1999. Cambior Alaska Inc., the largest placer mine in Alaska, operated in this district until September 1995 (fig. D-3).

67 Denali Prospect-At least six small, stratabound $\mathrm{Cu}$ lodes in volcanic sedimentary rocks of Triassic age that may contain 5 million tons ore that grade about $2 \% \mathrm{Cu}$ with credits of $\mathrm{Ag}$ (fig. D-1).

67a Zackly-Disseminated $\mathrm{Cu}$ and $\mathrm{Au}$ in a garnet-pyroxene skarn and marble. Reserves are estimated at 1.4 million tons grading 2.6 percent $\mathrm{Cu}$ and $0.175 \mathrm{oz} /$ ton $\mathrm{Au}$ (fig. D-1).

68 Chistochina - Porphyry Cu prospects of Tertiary age and placer Au district; produced more than 181,261 oz $\mathrm{Au}$ and small amount $\mathrm{Pt}$ from placer deposits (figs. D-2, D-3).

69 Nabesna mine - Classic high-grade Au skarn that envelopes quartz diorite of Jurassic(?) age; produced over $66,500 \mathrm{oz} \mathrm{Au}$ from about 88,000 tons of ore from 1930 to 1941 (fig. D-3).

70 Spirit Mountain-Massive and disseminated $\mathrm{Cu}-\mathrm{Ni}$ mineralization in mafic-ultramafic complex (fig. D-3).

71 Kennecott deposits - Major stratiform $\mathrm{Cu}-\mathrm{Ag}$ massive sulfide deposits localized near contact between Chitistone Limestone and Nikolai Greenstone of Triassic age; contained some of highest grade $\mathrm{Cu}$ lodes mined in North America. From 1911 to 1938, produced more than 1.2 billion $\mathrm{lb} \mathrm{Cu}$ and 10 million oz $\mathrm{Ag}$ from 4.8 million tons ore. Some reserves remain (fig. D-1).
72 Binocular and other prospects - Kennecott-type $\mathrm{Cu}-$ Ag massive sulfide deposits (fig. D-1).

73 Bond Creek-Orange Hill-Two major porphyry $\mathrm{Cu}-$ Mo deposits of Late Cretaceous age; reported inferred reserves of 850 million tons ore that grade 0.3 to $0.5 \%$ $\mathrm{Cu}$ and $0.03 \%$ Mo (fig. D-2).

74 Carl Creek-Porphyry Cu prospect in altered intrusive complex; similar to locality 73 (fig. D-2).

75 Baultoff - Porphyry Cu prospect in altered intrusive rocks; inferred reserves of 145 million tons of $0.20 \%$ Cu; similar to locality 73 (fig. D-2).

76 Horsfeld - Porphyry Cu prospect; similar to locality 73 (fig. D-2).

77 Midas mine - Significant stratabound $\mathrm{Cu}(\mathrm{Ag}-\mathrm{Au}-\mathrm{Pb}$ $\mathrm{Zn}$ ) massive sulfide deposit in volcanic sedimentary rocks of Tertiary Orca Group. Produced more than 3.3 million $\mathrm{lb} \mathrm{Cu}$ from 49,350 tons ore (fig. D-1).

78 Ellamar - Stratabound $\mathrm{Cu}-\mathrm{Zn}-\mathrm{Au}$ massive sulfide deposit in sediment of Eocene(?) Orca Group. Produced more than 16 million $\mathrm{lb} \mathrm{Cu}, 51,307 \mathrm{oz} \mathrm{Au}$, and 191,615 oz Ag from about 301,835 tons ore (fig. D-1).

79 Willow Creek, Independence, Lucky Shot, War Baby-Major lode $\mathrm{Au}$ deposits $(\mathrm{Ag}-\mathrm{Cu}-\mathrm{Pb}-\mathrm{Zn}-\mathrm{Mo})$ in veins that cut Mesozoic quartz diorite. Produced more than $606,400 \mathrm{oz} \mathrm{Au}$ from lode sources and about 55,600 $\mathrm{oz} \mathrm{Au}$ from associated placer deposits (fig. D-3).

80 Latouche, Beatson-Major stratabound $\mathrm{Cu}-\mathrm{Zn}-\mathrm{Ag}$ massive sulfide deposits in Orca Group sedimentary rocks and mafic volcanic rocks. Produced more than 205 million $\mathrm{lb} \mathrm{Cu}$ from 6 million tons ore. Inferred reserves of 5 million tons ore that grade $1 \% \mathrm{Cu}, 1.5 \%$ $\mathrm{Pb}+\mathrm{Zn}$ (fig. D-1).

81 Rua Cove - Major stratabound $\mathrm{Cu}-\mathrm{Zn}$ massive sulfide deposit in complex ore shoots enclosed in mafic volcanic rocks of Orca Group. Reported reserves of over 1.1 million tons ore that grade $1.25 \% \mathrm{Cu}$ (fig. D-1).

82 Red Mountain and Claim Point - Significant $\mathrm{Cr}$ occurrence associated with layered ultramafic complexes of Tertiary age at Red Mountain near Seldovia. More than 39,951 tons of metallurgical-grade ore shipped through 1976; huge low-grade $\mathrm{Cr}$ resource may remain, of which 30 million tons grade $5.1 \% \mathrm{Cr}_{2} \mathrm{O}_{3}$ (fig. D-3).

83 Red Devil-Major Hg-Sb deposit; high-grade epither$\mathrm{mal} \mathrm{Hg-Sb}$ deposit hosted in shear zones in Kuskokwim Group sedimentary rocks. More than 35,000 flasks $\mathrm{Hg}$ produced from 75,000 tons ore (fig. D-3).

84 Aniak district - Significant placer Au district. Aniak mining district produced $578,708 \mathrm{oz}$ Au from placer deposits, mainly from the Nyac and Donlin Creek areas (fig. D-3).

85 Goodnews Bay - Major placer Pt district; estimated to have produced over $555,000 \mathrm{oz}$ refined PGE metals from 1934 to 1976; one of the largest known PGE metal resources in United States. Possible resources of 60 million $\mathrm{yd}^{3}$ of deep, PGE-bearing gravels remain. Lode source believed to be Alaskan-type zoned 
ultramafic complex of Jurasssic or Cretaceous age. Possible significant offshore placer potential (fig. D-3).

86 Apollo-Sitka mines-Major lode Au deposits; produced more than $107,600 \mathrm{oz}$ Au from ore that averaged about $0.22 \mathrm{oz}$ ton $\mathrm{Au}$. Inferred reserves are 748,000 tons grading $0.76 \mathrm{oz} /$ ton $\mathrm{Au}, 2.16 \mathrm{oz} /$ ton $\mathrm{Ag}$, with base metal credits (fig. D-3).

87 Pyramid - Late Tertiary porphyry Cu-Mo deposit; inferred reserves of 125 million tons ore that grade $0.4 \% \mathrm{Cu}$ and $0.03 \%$ Mo reported (fig. D-2).

88 Ivanof - Late Tertiary porphyry Cu prospect; grades of up to $0.72 \% \mathrm{Cu}$ reported. Potential for large tonnages (fig. D2).

89 Weasel Mountain, Bee Creek-Porphyry $\mathrm{Cu}-\mathrm{Mo}$ prospect of late Tertiary to Quaternary age; grades of up to $0.48 \% \mathrm{Cu}$ and $0.035 \%$ Mo reported. Potential for moderate tonnages of low-grade mineralization (fig. D-2).

90 Mike deposit-Porphyry Mo prospect of late Tertiary age; grades of up to $0.21 \%$ Mo reported. Potential for large tonnages of low-grade Mo mineralization (fig. D-2).

91 Rex deposit-Porphyry Cu prospect similar to locality 90 ; grades of up to $0.3 \% \mathrm{Cu}$ reported. Potential for moderate reserves of low-grade mineralization (fig. D-2).

92 Kasna Creek-Major stratiform $\mathrm{Cu}-\mathrm{Pb}-\mathrm{Zn}$ and skarnsulfide deposits of Mesozoic age in mafic, volcanic, and sedimentary rocks; reported reserves of over 10 million tons ore that grade more than $1 \% \mathrm{Cu}$ (fig. D-1).

93 Sleitat Mountain - High-grade east-west-trending, Sn$\mathrm{W}-\mathrm{Ag}$ topaz-quartz greisen system hosted in 59million-year-old binary granite and in hornfels. Zone up to $3,000 \mathrm{ft}$ long and $500 \mathrm{ft}$ wide. One drill-hole showed $85 \mathrm{ft}$ of $1.8 \% \mathrm{Sn}$, and $0.4 \% \mathrm{~W}$. Inferred resources are 128 to 212 million $\mathrm{lb} \mathrm{Sn}$ in 29 million tons ore (fig. D-2).

94 Jimmy Lake - Complex Cu-Ag-Sn mineralization of late Tertiary(?) age; reported grades of up to $105 \mathrm{oz} /$ ton $\mathrm{Ag}$ and $3 \% \mathrm{Cu}$ (fig. D-1).

95 Haines Barite/Palmer-Major stratiform $\mathrm{Ba}-\mathrm{Pb}-\mathrm{Zn}$ $\mathrm{Cu}-\mathrm{Ag}$ deposit in pillow basalt-dominated section of Paleozoic or Triassic age; consists of 48 - to 60 -ft-thick zone of $60 \%$ barite with upper zone ( 2 to $8 \mathrm{ft}$ thick) of massive sulfides that contain $2 \% \mathrm{~Pb}, 3 \% \mathrm{Zn}, 1 \% \mathrm{Cu}$, up to $4 \mathrm{oz} /$ ton $\mathrm{Ag}$, and $0.12 \mathrm{oz} /$ ton Au. Estimated to contain 750,000 tons of $65 \%$ barite with $\mathrm{Zn}$ and $\mathrm{Ag}$ credits (fig. D-1).

96 Klukwan-Major Fe-Ti deposits in zoned ultramafic complex of Mesozoic age; reported to contain 3 billion tons of material that contains $16.8 \% \mathrm{Fe}$ and 1.6 to $3.0 \% \mathrm{Ti}$ (fig. D-3).

97 Nunatak-Porphyry Mo deposit; reported reserves of 2.24 million tons ore grading $0.67 \% \mathrm{Mo}, 0.16 \% \mathrm{Cu}$, and 129.5 million tons of $0.026 \% \mathrm{Mo}, 0.18 \% \mathrm{Cu}$ (fig. D-2).
98 Brady Glacier-Major $\mathrm{Ni}-\mathrm{Cu}$ deposit in layered gabbro-pyroxenite complex of Tertiary age. Proven reserves of 100 million tons ore that grade $0.5 \% \mathrm{Ni}$, $0.3 \% \mathrm{Cu}$ reported and about $0.03 \% \mathrm{Co}$; also contains PGE concentrations (fig. D-3).

99 Mertie Lode and Funter Bay mining districtContains substantial reserves of lode Au mineralization. Past production totaled about $15,000 \mathrm{oz}$ Au. Deposits also contain significant $\mathrm{Ni}-\mathrm{Cu}$ and $\mathrm{Pb}-\mathrm{Zn}-\mathrm{Ag}$ mineralization. Funter Bay deposit contains reported reserves of 560,000 tons that grade $0.34 \% \mathrm{Ni}, 0.35 \% \mathrm{Cu}$, and $0.15 \%$ Co in gabbro-pipe system (fig. D-3).

100 Alaska-Juneau - Major lode Au deposit that consists of 100 - to 300 -ft-wide zone that contains en echelon, Aubearing quartz veins in metamorphic rocks; produced more than 3.52 million oz Au from 88.5 million tons ore from 1893 to 1944 . Reserves (all categories) of 105.7 million tons of $0.05 \mathrm{oz} /$ ton Au remain (fig. D-3).

101 Chichagof and Hirst Chichagof-Major lode $\mathrm{Au}$ deposits in quartz veins that cut Mesozoic graywacke; produced more than $770,000 \mathrm{oz} \mathrm{Au}$, most of which was produced at Chichagof Mine. Inferred leased reserves estimated to be $100,000 \mathrm{oz} \mathrm{Au}$ (fig. D-3).

102 Mirror Harbor- $\mathrm{Ni}-\mathrm{Cu}$ mineralization in layered gabbro complex of Mesozoic age; reported proven reserves of 8,000 tons of $1.57 \% \mathrm{Ni}$ and $0.88 \% \mathrm{Cu}$ and reported inferred reserves of several million tons ore that grade $0.2 \% \mathrm{Ni}$ and $0.1 \% \mathrm{Cu}$ (fig. D-3).

103 Bohemia Basin - Major Ni-Cu-Co mineralization in layered mafic complex similar to locality 102 ; reported reserves of 22 million tons ore that grade 0.33 to $0.51 \%$ $\mathrm{Ni}, 0.21$ to $0.27 \% \mathrm{Cu}$, and $0.02 \% \mathrm{Co}$, all of which are recoverable with standard flotation technology (fig. D-3).

104 Apex-EI Nido-Significant lode Au-W deposits that occur as crosscutting veins in graywacke; produced more than 50,000 oz Au (fig. D-3).

105 Greens Creek-Major sediment-hosted $\mathrm{Pb}-\mathrm{Zn}-\mathrm{Cu}-$ $\mathrm{Ag}-\mathrm{Au}$ volcanogenic massive sulfide deposit of Devonian or Triassic age; most recent reserve estimate of the original orebody is 11.0 million tons grading $0.12 \mathrm{oz}$ ton $\mathrm{Au}, 13.3 \mathrm{oz} /$ ton $\mathrm{Ag}, 12.8 \% \mathrm{Zn}$, and $4.0 \% \mathrm{~Pb}$. Additional reserves in the southwest orebody are 2.0 million tons grading $13.5 \% \mathrm{Zn}, 5.5 \% \mathrm{~Pb}, 0.27 \mathrm{oz} /$ ton $\mathrm{Au}$, and $33 \mathrm{oz} /$ ton $\mathrm{Ag}$. Total combined reserves and resources of the mine are estimated to be 18 million tons (fig. D-1).

106 Sumdum - Volcanogenic $\mathrm{Cu}-\mathrm{Pb}-\mathrm{Zn}$ massive sulfide deposit in Mesozoic metamorphic complex with potential strike length of over $10,000 \mathrm{ft}$. Inferred reserves of 26.7 million tons ore that grade $0.57 \% \mathrm{Cu}$, $0.37 \% \mathrm{Zn}$, and $0.3 \mathrm{oz}$ ton $\mathrm{Ag}$ reported (fig. D-1).

107 Snettisham - Fe-Ti deposit in mafic zoned intrusive complex; reported grades of about $18.9 \% \mathrm{Fe}$ and $2.6 \%$ Ti (fig. D-3).

108 Tracy Arm - Stratabound $\mathrm{Cu}-\mathrm{Zn}-\mathrm{Pb}$ massive sulfide prospect in Mesozoic schist; over 1,100 ft long and up to 
$12 \mathrm{ft}$ thick. Reported grades of $1.5 \% \mathrm{Cu}, 3.9 \% \mathrm{Zn}, 0.76$ $\mathrm{oz}$ ton $\mathrm{Ag}$, and $0.013 \mathrm{oz}$ ton Au (fig. D-1).

109 Red Bluff Bay - Significant chrome mineralization in Mesozoic ultramafic complex (probably ophiolite); reported reserves of 570 tons of material that grade $40 \% \mathrm{Cr}$ and 29,000 tons that grade 18 to $35 \% \mathrm{Cr}$ (fig. D-3).

110 Cornwallis Peninsula - Volcanogenic $\mathrm{Cu}-\mathrm{Pb}-\mathrm{Zn}-\mathrm{Ag}-$ Ba massive sulfide deposit of Triassic(?) age; reported grades of up to $20 \% \mathrm{~Pb}-\mathrm{Zn}$ and $23 \mathrm{oz} /$ ton $\mathrm{Ag}$ (fig. D-1).

111 Castle Island - Stratiform barite deposit of Triassic age hosted in carbonate and pillow basalt; about 856,000 tons of raw and refined barite produced from 1963 to 1980; also contains $\mathrm{Zn}, \mathrm{Pb}$, and Cu sulfides. Reported to be mined out (fig. D-1).

112 Groundhog Basin-Area contains several massive sulfide prospects in Mesozoic schist and gneiss whose origins are now thought to be plutonic associated. Reported grades of up to $8 \% \mathrm{~Pb}, 29 \mathrm{oz} /$ ton $\mathrm{Ag}$, and $0.5 \mathrm{oz}$ ton $\mathrm{Au}$. Sn has also been recently identified. Area also contains potential for porphyry Mo deposits (fig. D-1).

113 Snipe Bay - Ni-Cu deposit in zoned mafic-ultramafic complex; inferred reserves of 430,000 tons of $0.3 \% \mathrm{Ni}$, $0.3 \% \mathrm{Cu}$, and $0.13 \mathrm{oz}$ ton $\mathrm{Ag}$ reported (fig. D-3).

114 Kasaan Peninsula - Major skarn-type $\mathrm{Cu}-\mathrm{Fe}-\mathrm{Au}$ massive sulfide deposit of Jurassic age; area has produced over 28 million $\mathrm{Ib} \mathrm{Cu}$, and $55,000 \mathrm{oz} \mathrm{Ag}$. Reported reserves of 4 million tons ore that grade $50 \% \mathrm{Fe}$ and less than $2 \% \mathrm{Cu}$ (fig. D-1).

115 Salt Chuck - Cu-PGM-Ag-Au deposit in contact zone between pyroxenite and gabbro within Alaskan-type zoned mafic-ultramafic pluton. From 1900 to 1941 , 5 million $\mathrm{lb} \mathrm{Cu}$, over $20,000 \mathrm{oz}$ PGM, and $\mathrm{Au}$ and $\mathrm{Ag}$ credits were produced from 325,000 tons ore (fig. D-3).

116 Union Bay - Significant Fe-Ti mineralization in ultramafic complex; area also contains $\mathrm{Pt}$ and V concentrations (fig, D-3).

117 Hyder mining district-Area produced more than 25,000 tons high-grade $\mathrm{W}-\mathrm{Cu}-\mathrm{Pb}-\mathrm{Zn}-\mathrm{Ag}$ ore from 1925 to 1951 from crosscutting ore shoots in Texas Creek granodiorite of Tertiary age. Area also contains potential for porphyry Mo-W mineralization and massive sulfide-skarn $\mathrm{Pb}-\mathrm{Ag}-\mathrm{Au}-\mathrm{W}$ deposits (figs. D-1, D-2).

118 Jumbo $\mathrm{Cu}-\mathrm{Fe}-\mathrm{Mo}-\mathrm{Ag}$ skarn deposit; produced more than 10 million $\mathrm{lb} \mathrm{Cu}, 280,000 \mathrm{oz} \mathrm{Ag}$, and 7,000 oz Au from 125,000 tons ore. Zoned magnetite-Cu skarns are associated with epizonal granodiorite pluton of Cretaceous age. Reported reserves of 650,000 tons ore that grade $45.2 \% \mathrm{Fe}, 0.75 \% \mathrm{Cu}, 0.01 \mathrm{oz}$ ton $\mathrm{Au}$, and $0.08 \mathrm{oz}$ ton $\mathrm{Ag}$ (fig. D-1).

119 Copper City - Stratiform $\mathrm{Cu}-\mathrm{Zn}-\mathrm{Ag}-\mathrm{Au}$ massive sulfide deposit hosted in late Precambrian or earliest Paleozoic Wales Group. Reported grades of up to $12.7 \% \mathrm{Cu}, 2.7 \% \mathrm{Zn}, 2.5 \mathrm{oz} /$ ton $\mathrm{Ag}$, and $0.2 \mathrm{oz} /$ ton $\mathrm{Au}$ (fig. D-1).
120 Quartz Hill - A porphyry Mo deposit hosted in a 25million-year-old composite felsic pluton. Probable reserves are 232 million tons with a grade of $0.22 \%$ $\mathrm{MoS}_{2}$, and possible reserves are 1.2 billion tons with $0.12 \% \mathrm{MoS}_{2}$ (fig. D-2).

121 Niblack - Volcanogenic $\mathrm{Cu}-\mathrm{Pb}-\mathrm{Au}-\mathrm{Ag}$ massive sulfide deposit hosted in Precambrian(?) Wales Group or Ordovician to Silurian Descon Formation; produced more than 1.4 million $\mathrm{lb} \mathrm{Cu}, 11,000 \mathrm{oz} \mathrm{Au}$, and $15,000 \mathrm{oz} \mathrm{Ag}$. Current resource is 2.78 million tons at $3.3 \% \mathrm{Zn}, 1.7 \% \mathrm{Cu}, 1.14 \mathrm{oz} /$ ton $\mathrm{Ag}$ and $0.087 \mathrm{oz} /$ ton $\mathrm{Au}$. The deposit is open to expansion (fig. D-1).

122 Bokan Mountain - Numerous U-Th prospects associated with Jurassic peralkaline intrusive complex: from 1955 to 1971 , produced more than 120,000 tons ore that graded about $1 \% \mathrm{U}_{3} \mathrm{O}_{8}$. Contains inferred reserves of about 40 million tons of $0.126 \% \mathrm{Nb}$ and up to $1 \%$ REE metals (fig. D-3).

123 Kemuk Mountain - Magmatic Fe-Ti deposit hosted in Cretaceous(?) pyroxenite. Inferred reserves of 2.4 billion tons that average 15 to $17 \% \mathrm{Fe}, 2$ to $3 \% \mathrm{TiO}_{2}$, and $0.16 \% \mathrm{P}_{2} \mathrm{O}_{5}$ (fig. D-3).

124 McLeod - Porphyry Mo deposit that contains quartzmolybdenite fissure veins in quartz-feldspar porphyry. Chip samples contain up to $0.09 \%$ Mo (fig. D-2).

125 Johnson River-Epigenetic(?) quartz-sulfide stockwork or massive sulfide deposit hosted in volcaniclastic, pyroclastic, and volcanic rocks of Jurassic Talkeetna Formation. Deposit has drilled-out reserves at a $\$ 45 /$ ton cutoff with no cut of high Au assays, 1,099,580 tons grading $0.32 \mathrm{oz} /$ ton $\mathrm{Au}, 0.24 \mathrm{oz} /$ ton $\mathrm{Ag}, 0.76 \% \mathrm{Cu}$, $1.17 \% \mathrm{~Pb}$, and $8.37 \% \mathrm{Zn}$ (fig. D-3).

126 Nimiuktuk River - Small hill of massive, high-grade barite estimated to contain at least 1.5 million tons barite. Widespread stream-sediment $\mathrm{Ba}$ anomalies in area indicate further barite potential (fig. D-1).

127 Kensington - Stockwork quartz veins in sheared and chloritized quartz diorite produced 10,900 tons grading $0.18 \mathrm{oz} /$ ton Au prior to 1930 . Recent reserve estimates indicate at least 11.5 million tons grading $0.143 \mathrm{oz}$ ton Au. Subparallel Horrible vein system contains 3.93 million tons grading $0.11 \mathrm{oz} /$ ton $\mathrm{Au}$ (fig. D-3).

128 Jualin - Five quartz-fissure veins in Cretaceous quartz diorite, more than $15,000 \mathrm{ft}$ of underground workings; produced $48,387 \mathrm{oz} \mathrm{Au}$, mainly prior to 1930 . Reserves estimated at 1.07 million tons of $0.349 \mathrm{oz}$ ton $\mathrm{Au}$ (fig, D-3).

129 Pebble Copper-Cu-Au porphyry with identified resource of 1 billion tons grading $0.30 \% \mathrm{Cu}$ and $0.010 \mathrm{oz}$ ton Au with Mo in the 0.03 to $0.04 \%$ range (fig. D-1).

130 Pogo - Au hosted in a series (3 discovered to date) of sub-parallel and tabular, gently dipping, quartz vein zones hosted by Paleozoic gneisses intruded by Cretaceous felsic plutonic rocks. Au in the $3 \mathrm{ft}$ to $60 \mathrm{ft}$ thick quartz bodies has a strong correlation with $\mathrm{Bi}$. A 1999 conservative kriged geological resource for the 
Liese L1 and L2 zones is 10.7 million tons at an average grade of $0.524 \mathrm{oz} /$ ton, for a total of 5.6 million oz at a $0.1 \mathrm{oz}$ ton cut-off grade. Other high-grade Au targets have been identified along an 8-mi-long trend southeast of the Liese zones (fig. D-3).

131 Shotgun Hills - Quartz stockwork and breccia $\mathrm{Au}-\mathrm{Cu}-$ As mineralization in a Late Cretaceous rhyolite (granite porphyry) stock. A preliminary, inferred Au resource of $980,000 \mathrm{oz}$ (36.11 million tons at an average grade of $0.027 \mathrm{oz} /$ ton $\mathrm{Au}$ ) at a $0.016 \mathrm{oz} /$ ton Au cut-off grade, with initial metallurgical tests indicating $>90 \% \mathrm{Au}$ recovery by cyanide leaching (fig. D-3).

132 Illinois Creek- $\mathrm{Au}-\mathrm{Ag}-\mathrm{Cu}-\mathrm{Pb}-\mathrm{Zn}-\mathrm{Bi}-\mathrm{As}$-bearing, $\mathrm{Fe}-\mathrm{Mn}$ oxide (gossan) shear zone crosscutting dolomitic quartzite localized near Cretaceous granitic pluton. Shear zone averages $148 \mathrm{ft}$ wide, has a drill-defined east-west strike length of $11,600 \mathrm{ft}$, and is open along strike and depth. Produced approximately $56,600 \mathrm{oz} \mathrm{Au}$ and $222,000 \mathrm{oz} \mathrm{Ag}$ from 1997 to 1999. Proven and probable reserves as of December 31, 1997, calculated using a $\$ 330$ Au price, totalled $144,200 \mathrm{oz}$ of Au represented by 1.9 million tons of ore at a grade of $0.076 \mathrm{oz}$ of $\mathrm{Au}$ and $1.6 \mathrm{oz}$ of Ag/ton (figs. D-1, D-3).

133 Calder Mine - Seven recrystallized carbonate units exposed at the apex of a large regional antiform. Drilling has identified 13 million tons of chemically homogenous, high-brightness, high-whiteness marble with a purity of 98 to $99 \%$ calcium carbonate. Potential resource of 80 million tons of high-value calcium carbonate (fig. D-2).

134 Vinasale Mountain - Intrusive-hosted Au deposit. Au mineralization is associated with arsenopyrite and pyrite in quartz-dolomite hydrothermal breccias, magmatic breccias, and zones of phyllic and silicic alteration hosted within a $69 \mathrm{Ma}$ quartz monzonite stock. Both disseminated and veinlet mineralization exist. An inferred resources of 14.35 million tons grading 0.067 $\mathrm{oz} /$ ton, with an $0.03 \mathrm{oz} /$ ton cut-off grade has been identified by drilling in the Central zone (fig. D-3).

135 Nixon Fork-Au-Cu skarn deposits; Nixon Fork mine produced $59,500 \mathrm{oz} \mathrm{Au}$ from Late Cretaceous skarns associated with quartz monzonite-Devonian limestone contact zones. Underground mining resumed in October 1995 , with $133,900 \mathrm{oz}$ of $\mathrm{Au}, 1,800$ tons of $\mathrm{Cu}$, and significant Ag produced through 1999 (fig. D-3).

136 Von Frank Mountain-Au and very weak Cu mineralization are associated with chalcopyrite, pyrite, and rare molybdenite within a zone of quartz stockwork veining hosted in a $69 \mathrm{Ma}$ quartz-diorite stock. The stock is a cupola of the larger Von Frank Pluton. Drill intercepts include thicknesses up to $429 \mathrm{ft}$ with an average grade of $0.013 \mathrm{oz} /$ ton Au. Higher grade intercepts include 0.035 oz/ton Au up to $135 \mathrm{ft}$.

(fig. D-3).

137 Donlin Creek - Au mineralization associated with disseminated pyrite and arsenopyrite, sulfide veinlets, and quartz-carbonate-sulfide veinlets in sericite-altered Late Cretaceous to early Tertiary rhyodacitic porphyry dikes and sills. Au mineralization is structurally controlled and refractory. The 1998 core drilling program increased the overall gold resource to $11.5 \mathrm{mil}-$ lion oz of $\mathrm{Au}$, with a measured and indicated resource of 5.4 million oz of Au contained in 62.8 million tons of ore grading $0.0876 \mathrm{oz} /$ ton Au (fig. D-3).

138 Kaiyah-Au-Ag epithermal prospect in silicified Koyukuk sedimentary rocks adjacent to Poison Creek caldera. Quartz veins, some over 100 feet thick, and silicification are associated with pervasive alunite, jarosite, and sericite alteration (fig. D-3). 


\section{APPENDIX E \\ State and federal agencies and private interest groups involved in mineral development activities, 1999}

(Note: The 1998 Service Directory of the Alaska Miners Association lists technical and professional consultants and companies available for work in Alaska. The report is available for \$15 from the Association's Anchorage office.)

\section{STATE OF ALASKA AGENCIES}

\section{DEPARTMENT OF COMMUNITY AND ECONOMIC DEVELOPMENT}

State Office Building, 9th Fl.

P.O. Box 110800 (mailing)

Juneau, AK 99811-0800

(907) $465-2500$

(907) 465-3767 (fax)

Function: Promotes economic development in Alaska.

Division of Community and Business Development

550 W. 7th Ave., Ste. 1770

Anchorage, AK 99501

(907) $269-8110$

(907) 269-8125 (fax)

State Office Building, 9th Fl. 333 Willoughby Ave. P.O. Box 110804 (mailing) Juneau, AK 99811-0804 (907) 465-2017

(907) $465-3767$ (fax)

http://www.dced.state.ak.us/cbd

email: frankie pillifant $@$ dced.state.ak.us

Function: Primary state government advocacy agency for economic growth. Researches and publishes economic data on Alaska's mining industry. Attracts capital investment by advertising Alaska's resource potential. Provides research staff aid for the Alaska Minerals Commission. The Division also encourages the development of new markets for Alaska resources. increases the visibility of Alaska and its products in the international marketplace, and makes referrals and provides technical assistance to those interested in developing export markets for Alaska-produced or value-added goods and services

\section{DEPARTMENT OF ENVIRONMENTAL CONSERVATION}

410 Willoughby Ave., Ste. 105

Juneau, AK 99801-1795

(907) $465-5010$

(907) 465-5040 TTY

(907) 465-5065 Commissioner's Office

(907) 465-5060 Public Information

Function: Issues permits for activities (including mining) that affect air or water quality or involve land disposal of wastes. Sets air-and water-quality standards. Inspects, monitors, and enforce. environmental quality statutes, regulations, and permits. Reviews all federal permits.

Alaska Department of Environmental Conservation Anchorage Office

555 Cordova St.

Anchorage, AK 99501-2617

(907) $269-7500$

(907) 269-7511 TYY

Permits/Compliance Assistance

1-800-510-2332 (inside Alaska only)

1-800-269-7586 (outside Alaska)

email: compass@envircon.state.ak.us

(907) 269-7600 (fax)
Alaska Department of Environmental Conservation

Fairbanks Office

610 University Ave.

Fairbanks, AK 99709-3643

(907) $451-2360$

(907) $451-2184$ TTY

(907) 451-2188 (fax)

\section{DEPARTMENT OF FISH AND GAME}

1255 W. 8 th St.

P.O. Box 25526 (mailing)

Juneau, AK 99802-5526

(907) $465-4100$

http://www.state.ak.us/local/akpages/FISH.GAME/habitat/ hab_home.htm

Habitat and Restoration Division

(907) $465-4105$

Function: Protects habitat in fish-bearing fresh waters and manages refuges, sanctuaries, and critical habitats. Requires permits for any work involving: the blockage of fish passage, equipment crossings or operation in fresh waters used by anadromous fish; use, diversion, or pollution of streams containing anadromous fish; construction, exploration, or development work in state game refuges, game sanctuaries, and critical habitat areas.
Northern Regional Office

Habitat and Restoration

1300 College Rd.

Fairbanks, AK 99701-1599

(907) 459-7289

Southeastern Regional Office

Habitat and Restoration Division

802 3rd St., 2nd Fl.

P.O. Box 240020 (mailing)

Douglas, AK 99824-0020

(907) $465-4290$

\section{OFFICE OF MANAGEMENT AND BUDGET}

Division of Governmental Coordination

240 Main St., Ste. 500

P.O. Box 110030 (mailing)

Juneau, AK 99811-0030

(907) 465-3562

Function: Conducts coordinated State review of permits for mining projects within Alaska's Coastal Management Zone. Provides project design information to applicants for consistency with the policies and standards of the Alaska Coastal Management Program. Coordinates State response to direct federal actions, including proposed regulations, that affect Alaska's mining industry.

Southcentral Regional Office

550 W. 7th St., Ste, 1660

Anchorage, AK 99501-3568

(907) 269-7470
Southcentral Regional Office AK 99518-1599 (907) 267-2285
(907) 269-3981 (fax) 


\section{DEPARTMENT OF NATURAL RESOURCES}

400 Willoughby Ave., 5 th Fl.

Juneau, AK 99801-1724

(907) $465-2400$

http://www.dnr.state.ak.us

Division of Forestry

550 W. 7th Ave., Ste. 1450

Anchorage, AK 99501

(907) 269-8463

http://www.dnr.state.ak.us/forestry

Function: Establishes guidelines to manage mining in state forests.

Interior Regional Office

3700 Airport Way

Fairbanks, AK 99709-4699

(907) 451-2660

Division of Geological \& Geophysical Surveys

794 University Ave., Ste. 200

Fairbanks, AK 99709-3645

(907) 451-5000

email: dggs@dnr.state.ak.us

http://wwwdggs.dnr.state.ak.us

(907) $451-5050$ (fax)

Function: Conducts geological and geophysical surveys to determine: the potential of Alaska land for production of metals, minerals, fuels, and geothermal resources; locations and supplies of construction materials; potential geologic hazards to buildings, roads, bridges, and other installations and structures; and other surveys and investigations as will advance knowledge of the geology of Alaska and general geologic inventories. Publishes a variety of reports that contain the results of these investigations. Advises the public and government agencies on geologic issues. Maintains a library of geologic bulletins, reports, and periodicals. Maintains a geologic materials storage facility at Eagle River.

Geologic Materials Center

P.O. Box 772805

Eagle River, AK 99577-2805

(907) 696-0079

(907) 696-0078 (fax)

Division of Mining, Land \& Water

550 W. 7 th Ave., Ste. 1070

Anchorage, AK 99501

(907) 269-8600

(907) 269-8904 (fax)

http://www.dnr.state.ak.us

\section{A. Mining}

Function: Principal agency for management of mining and reclamation on state land in Alaska. Maintains a mining office in Fairbanks. Issues property rights to leasable minerals; manages locatable mineral filings. Issues permits for hard-rock and placermining activity. Maintains records of mineral locations, permits, and leases. Provides technical, legal, and land-status information. Administers the Alaska Surface Mining Control and Reclamation Act (ASMCRA), which includes permitting and inspection of coal mining activity and reclamation of abandoned mines.

B. Land

Function: Manages surface estate and resources, including materials (gravel, sand, and rock). Handles statewide and regional land-use planning. Issues leases, material-sale contracts, mill-site leases, land-use permits, and easements for temporary use of State land and access roads. Administers land sales program.

\section{Water Management}

Function: Manages water resources of the state; issues waterappropriation permits and certificates; responsible for safety of all dams in Alaska; conducts surveys to determine the locations, quantity, and quality of ground and surface water.

Northern Regional Office

3700 Airport Way

Fairbanks, AK 99709-4699

(907) $451-2700$

(907) 451-2751 (fax)

Southeastern Regional Office 400 Willoughby Ave., 4th Fl. Juneau, AK 99801-1724

(907) 465-3400

(907) 586-2954 (fax)

Division of Parks and Outdoor Recreation

550 W. 7th Ave., Ste.1310

Anchorage, AK 99501

(907) $269-8700$

Function: Manages approximately 3,000,000 acres of state park lands primarily for recreational uses, preservation of scenic values, and watershed. Responsible for overseeing mining access, recreational mining activity, and valid mining-claim holdings within state park lands. The Office of History and Archaeology reviews mining permit applications on all lands within the state for impacts to historic resources.

Northern Regional Office

3700 Airport Way

Fairbanks, AK 99709-4699

(907) 451-2695

Office of History and Archaeology

550 W. 7th Ave., \#1310

Anchorage, AK 99501

(907) 269-8721

email: michelej@dnr.state.ak.us

\section{DEPARTMENT OF PUBLIC SAFETY}

450 Whittier St. P.O. Box 111200 (mailing)

Juneau, AK 99811-1200

(907) $465-4322$

\section{Division of Fish and Wildlife Protection}

5700 East Tudor Rd.

Anchorage, AK 99507-1225

(907) 269-5509

Function: Enforces state laws, in particular AS Title 16. Protects Alaska's fish and wildlife resources through enforcement of laws and regulations governing use of natural resources within Alaska. These laws are in Alaska Statutes 8, 16, 46, and Alaska Administrative Codes 5, 12, and 20 .

\section{DEPARTMENT OF REVENUE}

State Office Bldg.

11 th Fl., Entrance A

P.O. Box 110400 (mailing)

Juneau, AK 99811-0400

(907) $465-2300$

http://www.revenue.state.ak.us

Tax Division

State Office Bldg., Il th Fl., Entrance B

P.O. Box 110420 (mailing)
Southeastern Regional Office 400 Willoughby Ave., 4th Fl. Juneau, AK 99801-1724 (907) $465-4563$
Southcentral Regional Office Anchorage, AK 99501

907) $269-8503$

907) 269-8947 (fax) 
Juneau, AK 99811-0420

(907) $465-2320 \quad$ (907) $465-2375$ (fax)

email: fish excise@revenue.state.ak.us

http://www.revenue.state.ak.us/iea/

Function: Issues licenses for mining, production, and sale of minerals. Administers mining-license tax based on net income. including royalties. New mining operations - except sand and gravel mining - can apply for and receive certificates of tax exemption for the first $31 \% 2$ years of operation. (Tax returns must be filed annually.)

\section{UNIVERSITY OF ALASKA}

College of Science, Engineering, and Mathematics

Department of Geology \& Geophysics

308 Natural Sciences Bldg.

University of Alaska Fairbanks

Fairbanks, AK 99775-5780

(907) $474-7565$

email: geology@zorba.uafadm.alaska.edu

http://www.uaf.edu/geology

Function: Provides undergraduate and graduate education in geology and geophysics and conducts basic and applied research in geologic sciences. Offers B.S., M.S., and Ph.D. program options in general geology, economic geology, petroleum geology, geophysics, and ice-snow-permafrost geophysics.

\section{School of Mineral Engineering}

P.O. Box 755960

Brooks Building - Rm. 209

University of Alaska Fairbanks

Fairbanks, AK 99775-5960

(907) 474-7366

(907) 474-6994 (fax)

email: FYSME@uaf.edu

http://sme.uaf.edu

Function: Provides undergraduate and graduate education programs in geological engineering, mining engineering, mineral preparation engineering, and petroleum engineering. Through research programs conducts laboratory and field studies to promote mineral and energy development.

Mineral Industry Research Laboratory (MIRL)

School of Mineral Engineering

O'Neill Resources Bldg., Rm. 229

University of Alaska Fairbanks

Fairbanks, AK 99775-7240

(907) 474-6746

(907) 474-5400 (fax)

Function: Conducts applied and basic research in exploration, development, and utilization of Alaska's mineral and coal resources with emphasis on coal characterization, coal utilization, coal upgrading, coal preparation, mineral beneficiation, fine gold recovery, hydrometallurgy, and environmental concerns. Publishes reports on research results and provides general information and assistance to the mineral industry.

\section{Mining Extension Program}

Duckering Bldg., Rm. 401

University of Alaska Fairbanks

Fairbanks, AK 99775-5800

(907) $474-7702$

Function: Offers prospecting and introductory mineral and mining courses under an open admissions policy.

Mining and Petroleum Training Service 155 Smith Way, Ste. 101

University of Alaska Anchorage

Soldotna, AK 99669

(907) 262-2788

Function: Provides direct training and assistance to mine operators, service and support companies, and governmental agencies in mine safety and health, mining extension, vocational mine training, and technical transfer. Specialized training services in hazardous materials, first aid and CPR, industrial hygiene, and professional safety education and consulting are available on demand.

\section{FEDERAL AGENCIES}

\section{U.S. DEPARTMENT OF THE INTERIOR}

Office of the Secretary

1689 C St., Ste. 100

Anchorage, AK 99501-5151

(907) $271-5485$

(907) $271-4102$

Function: Coordinates the Department of the Interior's policy and stewardship with DOI bureaus for the management of over 200 million acres of public land in Alaska.

\section{Bureau of Land Management}

Alaska State Office

Division of Lands, Minerals, and Resources

222 West 7th Ave., Ste. 13

Anchorage, AK 99513-7599

(907) 271-5477

Lands \& Minerals Group

Public Land Information Center

Anchorage Mineral Resources Team

http://www.ak.blm.gov/

(907) 271-5049

(907) $271-5960$

(907) $271-2454$

Function: Surface manager of federal public lands (except national parks, wildlife refuges, national monuments, national forests, and military withdrawals). Performs a variety of land administration functions for federal lands. Responsible for many minerals functions on federal lands, including issuing leases for all federal leasable minerals including oil and gas, coal, phosphates, and oil shale. Arranges for sale of minerals other than leasable or materials, such as sand, gravel, or stone. Issues rights-of-way and special use permits. Monitors mining operations to ensure protection of surface resources. Maintains land status plats and issues patents. Records federal mining claims and annual assessment affidavits, and collects annual claim holding fees.

The Anchorage and Juneau Mineral Resources Teams conduct studies that aid environmentally sound development of a viable mineral industry in Alaska. Emphasis is on field programs that identify the type, amount, and distribution of mineral deposits in Alaska. The field information is augmented by studies of beneficiation technologies, economic feasibility, and economic and environmental effects of mineral development. Information is provided to government agencies to aid land-planning and landuse decisions, and to the private sector to identify targets of opportunity for further exploration and/or development.

Anchorage Field Office 6881 Abbott Loop Rd.

Anchorage, AK 99507-2599

(907) $267-1246$

(907) $267-1267$ (fax)

Juneau Mineral Information Center Juneau Mineral Resources Team 100 Savikko Rd.
Glennallen Field Office

P.O. Box 147

Glennallen, AK 99588

(907) $822-3217$

(907) $822-3120$ (fax) 
Mayflower Island

Douglas, AK 99824

(907) $364-1553$

email: jalbrech@ak.blm.gov

(907) $364-1574$ (fax)

http://juneau.ak.blm.gov

Function: Conducts mineral assesment and economic engineering and environmental studies primarily on federal lands. Library contains 20,000 geologic and minerals publications and provides a variety of on-line land status and mineral information services.

Kotzebue Field Station

P.O. Box 1049

Kotzebue, AK 99752-1049

(907) 442-3430

(907) $442-2720$ (fax)

Northern Field Office

1150 University Ave.

Fairbanks, AK 99709-3899

(907) 474-2200

(907) 474-2251 Public Room

$1-800-437-7021$

\section{U.S. Fish and Wildlife Service}

Region 7 Office

1011 East Tudor Rd.

Anchorage, AK 99503

(907) $786-3542$

http://www.r7.fws.gov/

Function: Administers the federal public lands in national wildlife refuges, issues special-use permits for activities on refuges, reviews permits and applications for various mining activities on all private and public lands and waters, and provides information to regulatory agencies on fish and wildlife and their habitat. Makes recommendations to regulatory agencies to mitigate adverse environmental impacts.

U.S. Fish and Wildlife Service Fairbanks Ecological Services 101 12th Ave., Rm. 110

Box No. 19

Fairbanks, AK 99701

(907) 456-0327

(907) 456-0208 (fax)

P.O. Box 925

Nome, AK 99762-0925

(907) 443-2177

(907) 443-3611 (fax)

U.S. Fish and Wildlife Service

Anchorage Field Office

605 West 4th Ave., Rm. G-62

Anchorage, AK 99501

(907) 271-2888

(907) 271-2786 (fax)

\section{U.S. Geological Survey}

Geological Division

4200 University Dr.

Anchorage, AK 99508-4663

(907) $561-1181$

Function: Investigates and reports on the occurrence, quality, quantity, and environmental characteristics of mineral resources, the processes that create and modify them, models for assessing mineral endowment. and the potential impacts of mineral development. A major aspect of this research involves 1:250,000scale geologic mapping.

Water Resources Division

4230 University Dr., Ste. 201

Anchorage, AK 99508-4664

(907) $786-7100$
U.S. Geological Survey Earth Science Information Center

National Mapping Division

4230 University Dr., Ste. 101

Anchorage, AK 99508-4664

(907) 786-7011

Function: Publishes and distributes all available topographic maps of Alaska, digital products, and aerial photography.

National Park Service

Alaska Regional Office

Physical Resources

2525 Gambell St.

Anchorage, AK 99503-2892

(907) $257-2632$

(907) $257-2448$ (fax)

Function: Administers lands within the national park system in Alaska. Manages oil and gas operations and pre-existing valid mining claims in parklands through plans of operation under Mining in Parks Act, National Park Service regulations, and other applicable federal and state laws and regulations.

\section{U.S. DEPARTMENT OF LABOR}

Mine Safety and Health Administration

205 N. 4th St.

Coeur d'Alene, ID 83814-2877

$\begin{array}{ll}\text { (208) } 667-6680 & \text { (208) } 765-3099 \text { (fax) }\end{array}$

Mine Safety and Health Administration

Anchorage Federal Building

US Courthouse - Rm. 126

222 West 7th Ave., Box 30

Anchorage, AK 99513

(907) $271-1250$

email: osborn-russell@msha.gov

(907) $271-1252$ (fax)

Function: Administers health and safety standards to protect the health and safety of metal, nonmetal, and coal miners. Cooperates with the State to develop health and safety programs and develops training programs to help prevent mine accidents and occupationally caused diseases. Under agreement with the Coal Mine Safety and Health Office, the MSHA metal/nonmetal section has assumed responsibility for enforcement and training activities at coal mines in Alaska.

Mine Safety and Health Administration

Coal Mine Safety and Health, District 9

P.O. Box 25367

Denver, CO 80225

(303) $231-5458$

http://www.msha.gov

(303) 231-5553 (fax)

Function: Administers health and safety standards according to the Code of Federal Regulations to protect the health and safety of coal miners; requires that each operator of a coal mine comply with these standards. Cooperates with the State to develop health and safety programs and develops training programs to help prevent coal or other mine accidents and occupationally caused diseases in the industry.

\section{U.S. DEPARTMENT OF AGRICULTURE}

\section{Forest Service}

Regional Office, Federal Bldg.

P.O. Box 21628

Juneau, AK 99802-1628

(907) 586-7869

(907) 586-7866 (fax)

email: jkato@fs.fed.us

http://www.fs.fed.us/

http://www.fs.fed.us/r10/ 
Function: With the Bureau of Land Management, provides joint administration of general mining laws on national forest system lands. Cooperates with Department of Interior agencies in the review and issuance of mineral leases. Issues permits for disposal of sand, gravel, and stone.

\section{U.S. ENVIRONMENTAL PROTECTION AGENCY}

Region 10 Regional Office

1200 6th Ave., MS OW-130

Seattle, WA 98101

(206) $553-1200$

(206) 553-1746 (NPDES permits)

http://www.epa.gov/rioearth/

Function: Issues National Pollutant Discharge Elimination System (NPDES) permits under the Clean Water Act to regulate effluent discharges. Implements a compliance enforcement program. Maintains regulatory and review authority over wetland and NEPA/EIS-related issues.
Alaska Operations Office

222 West 7 th Ave., Rm. 537

222 W. 7th Ave., Box 19 (mailing)

Anchorage, AK 99513-7588

(907) $271-5083$
Alaska Operations Office

Ste. 100

410 Willoughby Ave.

Juneau, AK 99801

(907) $586-7619$

\section{U.S. DEPARTMENT OF THE ARMY}

\section{Corps of Engineers}

Regulatory Branch

Attention: CEPOA-CO-R

P.O. Box 898

Anchorage, AK 99506-0898

(907) $753-2712$

(800) 478-2712 (in Alaska only)

(907) $753-2716($ fax)

Function: Regulates structures or work in navigable waters of the U.S. and discharge of dredged or fill material into U.S. waters, including wetlands. Examples of regulated mining activities include construction of berms, dikes, diversions, ponds, overburden stripping, stockpiling, and reclamation activities.

\section{COOPERATIVE STATE-FEDERAL AGENCIES}

Alaska Public Lands Information Center

250 Cushman St., Ste. 1A

Fairbanks, AK 99701

(907) 456-0527 (907) 456-0514 (fax)

(907) 456-0532 (TDD for hearing impaired)

http://www.nps.gov/aplic

Function: Clearinghouse for general information on outdoor recreation in Alaska. Information sources include U.S. Forest Service, U.S. Fish and Wildlife Service, U.S. Bureau of Land Management, U.S. Geological Survey, National Park Service, Alaska Departments of Natural Resources and Fish and Game, and Alaska Division of Tourism.

\section{BOARDS AND COMMISSIONS}

Alaska Minerals Commission
Irene Anderson, Chair
c/o Sitnasuak Native Corp.
P.O. Box 905
Nome, AK 99762
$\begin{array}{ll}\text { (907) } 443-2632 & \\ \text { (907) 443-4023 } & \text { (907) } 443-3063 \text { (fax) } \\ \text { email: Ianderson@snc.org } & \end{array}$

Function: The Minerals Commission was created by the Alaska State Legislature in 1986 to make recommendations to the Governor and the Legislature on ways to mitigate constraints on the development of minerals in Alaska. The Commission has published anmual reports since 1987.

Alaska Science \& Technology Foundation

4500 Diplomacy Dr., Ste. 515

Anchorage, AK 99508

(907) $272-4333$

(907) 274-6228 (fax)

email: bchaney@astf.org

http://www.astf.org

Function: The Foundation was created to make public funds available for long-term investment in economic development and technological innovation within the state and to improve the health status of its residents. Through the awarding of grants for basic and applied research and development, the Foundation will enhance the state's economy and help build its science and engineering capabilities.

\section{CHAMBERS OF COMMERCE}

Alaska State Chamber of Commerce

217 Second St., Ste. 201

Juneau, AK 99801

(907) $586-2323$

(907) $463-5515$ (fax)

email: asccjuno@ptialaska.net

http://www.alaskachamber.com

Function: The State Chamber of Commerce researches and formulates positions on Alaskan resource development. Recommendations for consideration are submitted to the State Chamber of Commerce board of directors.

Anchorage Chamber of Commerce

441 West 5 th Ave., Ste. 300

Anchorage, AK 99501

(907) 272-2401

email: info@anchoragechamber.org

http://www.anchoragechamber.org

Greater Fairbanks Chamber of Commerce

250 Cushman St., Ste. 2D

Fairbanks, AK 99701-4665

(907) 452-1105

(907) 456-6968

email: cocstaff $@$ mosquitonet.com

http://www. fairbankschamber.org

Juneau Chamber of Commerce

3100 Channel Dr., Ste. 300

Juneau, AK 99801

(907) 463-3488

email: jchcomm $a$ ptialaska.net

(907) 463-3489 (fax) 


\section{PUBLIC INTEREST GROUPS} AND ASSOCIATIONS

Alaska Miners Association Inc.

Statewide Office

3305 Arctic Blvd., Ste. 202

Anchorage, AK 99503

$\begin{array}{ll}\text { (907) } 563-9229 & \text { (907) 563-9225 (fax) }\end{array}$

email: ama@alaskaminers.org

http://www.alaskaminers,org

Denali Branch of AMA

P.O. Box 1000

Healy, AK 99743

(907) 683-2226, ext. 719

Fairbanks Branch of AMA

P.O. Box 81906

Fairbanks, AK 99708-1906

(907) 458-8951

Juneau Branch of AMA

3100 Channel Dr., \#2

Juneau, AK 99801

(907) 463-4489

Kenai Branch of AMA

P.O. Box 3503

Soldotna, AK 99669-3503

(907) 262-4472

Nome Branch of AMA

P.O. Box 1107

Nome, AK 99762-1107

(907) 443-5168

Alaska Women in Mining

Juneau Branch

P.O. Box 34044

Juneau, AK 99804

(907)586-4161

Anchorage Branch

P.O. Box 240334

Anchorage, AK 99524

(907) 276-6762

Alaskans for Juneau

P.O. Box 22428

Juneau, AK 99802-2428

(907) 463-5065

American Institute of

Professional Geologists

8703 Yates Dr., Ste. 200

Westminster, CO 80031-3681

$\begin{array}{ll}\text { (303) } 412-6205 & \text { (303) } 412-6219 \text { (fax) }\end{array}$

email: aipg@aipg.org

http://www.aipg.org

Alaska Section

7127 Old Seward Highway

Anchorage, AK 99518

(907) 563-2890
Earthjustice Legal Defense Fund

325 Fourth St.

Juneau, AK 99801

$\begin{array}{ll}\text { (907) } 586-2751 & \text { (907) 463-5891 (fax) }\end{array}$ email: eajusak@earthjustice.org

http://www.earthjustice.org

National Wildlife Federation

750 W. Second Ave., Ste. 200

Anchorage, AK 99501

$\begin{array}{ll}\text { (907) } 258-4800 & \text { (907) 258-4811 (fax) }\end{array}$

Neighborhood Mine Watch

P.O. Box 84531

Fairbanks, AK 99708-4531

(907) 479-3096

email: nmw@mosquitonet.com

Northern Alaska Environmental Center

218 Driveway St.

Fairbanks, AK 99701-2806

(907) 452-5021

(907) 452-3100

email: naec@northern.org

http://www.northern.org

Northwest Mining Association

10 North Post St.. Ste. 414

Spokane, WA 99201

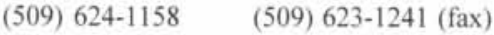

email: nwma@nwma.org

http://www.nwma.org

Resource Development

Council for Alaska, Inc.

121 W. Fireweed Ln., Ste. 250

Anchorage, AK 99503

$\begin{array}{ll}\text { (907) } 276-0700 & \text { (907) } 276-3887 \text { (fax) }\end{array}$

email: Resources@akrdc.org

Society for Mining, Metallurgy, and

Exploration Inc.

P.O. Box 625002

Littleton. CO 80162-5002

$\begin{array}{lll}\text { (303) } 973-9550 & \text { (303) } 973-3845 \text { (fax) }\end{array}$

Secretary Treasurer-John Rishel

1505 Atkinson Dr.

Anchorage, AK 99504

(907) 337-0511

Southeast Alaska Conservation Council

(SEACC)

419 6th St., Ste. 328

Juneau, AK 99801

(907) 586-6942 (907) 463-3312 (fax)

email: info@seacc.org

http://www.seacc.org

Trustees for Alaska

1026 W. 4th Ave., \# 201

Anchorage, AK 99501-1980

(907) 276-4244

email: ecolaw@ trustees.org

\section{ORGANIZED MINING DISTRICTS}

Circle Mining District

P.O. Box 80674

Fairbanks, AK 99708

(907) 488-6058

Fairbanks Mining District

105 Dunbar

Fairbanks, AK 99701

(907) 456-7642

Haines Mining District

P.O. Box 149

Haines, AK 99827

(907) $766-2228$

Iditarod Mining District

John A. Miscovich

General Delivery

Flat, AK 99584

Kantishna Mining District

Valerie Mundt

P.O. Box 84608

Fairbanks, AK 99708

vmundt@hotmail.com

Livengood-Tolovana Mining District

P.O. Box 55698

North Pole, AK 99705

(907) 488-6453

Valdez Creek Mining District

P.O. Box 875534

Wasilla, AK 99687-5534

Yentna Creek Mining District

P.O. Box 211

Talkeetna, AK 99676

\section{MINERAL EDUCATION PROGRAMS}

ALASKA MINERAL AND ENERGY RESOURCE EDUCATION FUND (AMEREF)

c/o RDC

121 W. Fireweed Ln., Ste. 250

Anchorage, AK 99503

$\begin{array}{ll}\text { (907) } 276-0700 & \text { (907) 276-3887 (fax) }\end{array}$

email; resources@akrdc.org

Function: A nonprofit corporation formed to help prepare students in grades $K-12$ to make informed decisions about Alaska's mineral and energy resources.

\section{Alaska Department of Education and} Early Development

801 W. 10th St., Ste. 200

Juneau, AK 99801-1894

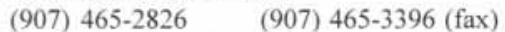

email: Cynthia_Curran@eed.state.ak.us http://www.eed.state.ak.us/tls/minerals/

minerals.html 


\section{NATIVE REGIONAL CORPORATIONS}

\section{AHTNA INC}

Main Office

P.O. Box 649

Glennallen, AK 99588-0649

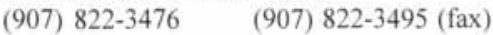

http://www.ahtna-inc.com/

\section{Anchorage Office}

406 Fireweed Ln., Ste. 204

Anchorage, AK 99503-2649

(907) 274-7662 (907) 274-6614 (fax)

\section{THE ALEUT CORP.}

4000 Old Seward Hwy., Ste. 300

Anchorage, AK 99503-6087

(907) $561-4300 \quad$ (907) $563-4328$ (fax)

email:aleut@alaska.net

http://www.aleutcorp.com

\section{ARCTIC SLOPE REGIONAL CORP.}

P.O. Box 129

Barrow, AK 99723-0129

(907) $852-8633$

(907) 852-5733 (fax)

http://www.asrc.com/

Anchorage Office

301 Arctic Slope Ave., Ste. 300

Anchorage, AK 99518-3035

(907) $349-2369$

(907) 349-5476 (fax)
BERING STRAITS NATIVE CORP.

P.O. Box 1008

Nome, AK 99762-1008

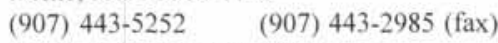

email: sparks@beringstraits.com

http://www.beringstraits.com/

\section{BRISTOL BAY NATIVE CORP.}

800 Cordova St., Ste. 200

Anchorage, AK 99501-3717

(907) 278-3602

(907) 276-3924 (fax)

http://www.bbnc.net

\section{CALISTA CORP.}

301 Calista Court, Ste. A

Anchorage, AK 99518-3028

(907) 279-5516

(907) $272-5060$ (fax)

http://www.calistacorp.com/

\section{CHUGACH ALASKA CORP.}

560 E. 34th Ave., Ste. 200

Anchorage, AK 99503-4196

$\begin{array}{lll}\text { (907) } 563-8866 & \text { (907) } 561-6961 \text { (fax) }\end{array}$

email: rrogers@chugach-ak.com

http://www.chugach-ak.com/

\section{COOK INLET REGION INC}

and its subsidary North Pacific

Mining Corporation

P.O. Box 93330

Anchorage. AK 99509-3330

$\begin{array}{lll}\text { (907) } 274-8638 & \text { (907) 263-5190 (fax) }\end{array}$

email: cbeery@ciri.com

http://www.ciri.com/
DOYON LTD.

1 Doyon Place, Ste. 300

Fairbanks, AK 99701-2941

$\begin{array}{ll}\text { (907) } 459-2030 & \text { (907) 459-2062 (fax) }\end{array}$

email: land@doyon.com

http://www.doyon.com

\section{KONIAG INC.}

4300 B St., Ste. 407

Anchorage, AK 99503

$\begin{array}{ll}\text { (907) } 561-2668 & \text { (907) } 562-5258 \text { (fax) }\end{array}$

http://www.koniag.com

\section{NANA REGIONAL CORP.}

P.O. Box 49

Kotzebue, AK 99752

(907) 442-3301

(907) 442-2866 (fax)

http://www.nana-online.com/

Anchorage Office

1001 E. Benson Blvd.

Anchorage, AK 99508

$\begin{array}{ll}\text { (907) } 265-4100 & \text { (907) } 265-4123 \text { (fax) }\end{array}$

\section{SEALASKA CORP.}

One Sealaska Plaza, Ste. 400

Juneau, AK 99801

(907) 586-1512 (907) 586-2304 (fax)

http://www.sealaska.com/ 


\section{APPENDIX F Alaska Mining Websites}

\section{Mining Companies}

\begin{tabular}{|c|c|}
\hline $\begin{array}{l}\text { Abacus Minerals Corp. } \\
\text { Almaden Resources Corp. } \\
\text { Atna Resources Ltd. }\end{array}$ & $\begin{array}{l}\text { http://www.abacusminerals.com/ } \\
\text { http://www.almadenresources.com/ } \\
\text { http://www.atna.com/ }\end{array}$ \\
\hline Avalon Development Corp. & http://www.alaska.net/ avalon/ \\
\hline Barrick Gold Co. & http://www. barrick.com/ \\
\hline Boliden Limited & http://www.boliden.ca/ \\
\hline Cambior Inc. & http://www.cambior.com \\
\hline Camflo Resources Ltd. & http://www.camflo.com/s/default.asp \\
\hline Camnor Resources Ltd. & http://www.northair.com/camnor/ \\
\hline Coeur d'Alene Mines Corp. (Coeur Alaska Inc.) & http://www.coeur.com/ \\
\hline Cominco Ltd. (Cominco Alaska Inc.) & http://www.cominco.com/ \\
\hline Copper Ridge Explorations Inc. & http://www.copper_ridge.com \\
\hline Cusac Gold Mines Ltd. & http://www.cusac.com \\
\hline Engineer Mining Corp. & http://www.emcorp.yk.ca/ \\
\hline Exploration Orbite VSPA Inc. (Yellow Eagle Mining Co.) & http://www.explorationorbite.com/Index.html \\
\hline Golden Phoenix Minerals Inc. & http://www.golden-phoenix.com/ \\
\hline Grayd Resource Corp. & http://www.grayd.com/ \\
\hline Great Quest Metals Ltd. & http://www.greatquest.com \\
\hline $\begin{array}{l}\text { Hecla Mining Co. } \\
\text { Hyder Gold Inc. } \\
\text { Inco Ltd. }\end{array}$ & $\begin{array}{l}\text { http://www.hecla-mining.com/ } \\
\text { http://www.bmts.bc.ca/hgi// } \\
\text { http://www.incoltd.com/ }\end{array}$ \\
\hline International Bravo Resource Corp. & http://www.internationalbravo.com \\
\hline International Freegold Mineral Development Inc. & http://www.augoldgroup.com/itf.html \\
\hline Kennecott Exploration Co. & http://www.kennecottexploration.com/ \\
\hline Kennecott Minerals Co. & http://www.kennecottminerals.com/ \\
\hline Kinross Gold Corp. & http://www.kinross.com/ \\
\hline Latitude Mineral Corp. & http://www.latitudeminerals.com \\
\hline Newmont Mining Corp. & http://www.newmont.com/ \\
\hline North Star Exploration Inc. & http://www.northstarexploration.com/ \\
\hline NovaGold Resources Inc. & http://www.nrigold.com/ \\
\hline Pacific Bay Minerals Ltd. & http://www.pacific-bay.com/ \\
\hline Placer Dome Inc. & http://www.placerdome.com/ \\
\hline Rimfire Minerals Corp. & http://rimfire.bc.ca/ \\
\hline Rubicon Minerals Corp. & http://www.rubiconminerals.com/home.htm \\
\hline Shear Minerals Ltd. & http://www.shearminerals.com \\
\hline Silverado Gold Mines Ltd. & http://www.silverado.com/ \\
\hline Teck Corp. & http://www.teckcorp.cal \\
\hline Teryl Resources Corp. & http://www.terylresources.com \\
\hline Tri-Valley Corp. & http://www.tri-valleycorp.com/ \\
\hline Troymin Resources Ltd. & http://www.troymin.com/ \\
\hline Usibelli Coal Mine Inc. & http://www.usibelli.com/ \\
\hline Ventures Resource Corp. & http://www.venturesresource.com/ \\
\hline Viceroy Exploration Corp. & http://www.viceroyresource.com/ \\
\hline Western Keltic Mines Inc. & http://www.keltic.com/ \\
\hline
\end{tabular}




\section{Alaska Native Corporations}

\begin{tabular}{|c|c|}
\hline $\begin{array}{l}\text { Ahtna Inc. } \\
\text { Aleut Corp. } \\
\text { Arctic Slope Regional Corp. }\end{array}$ & $\begin{array}{l}\text { http://www.ahtna-inc.com/ } \\
\text { http://www.aleutcorp.com/ } \\
\text { http://www.asrc.com/ }\end{array}$ \\
\hline $\begin{array}{l}\text { Bering Straits Native Corp. } \\
\text { Bristol Bay Native Corp. } \\
\text { Calista Corp. }\end{array}$ & $\begin{array}{l}\text { http://www. beringstraits.com/ } \\
\text { http://touchngo.com/BBNC/ } \\
\text { http://www.calistacorp.com/ }\end{array}$ \\
\hline $\begin{array}{l}\text { Chugach Alaska Corp. } \\
\text { Cook Inlet Region Inc. } \\
\text { Doyon Ltd. }\end{array}$ & $\begin{array}{l}\text { http://www.chugach-ak.com/ } \\
\text { http://www.ciri.com/ } \\
\text { http://www.doyon.com/ }\end{array}$ \\
\hline $\begin{array}{l}\text { Koniag Inc. } \\
\text { NANA Regional Corp. } \\
\text { Sealaska Corp. }\end{array}$ & $\begin{array}{l}\text { http://www.koniag.com/ } \\
\text { http://www.nana.com/ } \\
\text { http://www. sealaska.com/ }\end{array}$ \\
\hline
\end{tabular}


APPENDIX G

\section{U.S. Customary Units/Metric Units Conversion Chart}

To convert from:

To:

Multiply by:

\begin{tabular}{|c|c|c|}
\hline \multicolumn{3}{|c|}{ Weight/Mass/Ore Content } \\
\hline ounces (avoirdupois) & grams & 28.350 \\
\hline ounces (troy) & grams & 31.1035 \\
\hline pounds & kilograms & 0.4536 \\
\hline short tons & metric tons & 0.9072 \\
\hline grams & ounces (avoirdupois) & 0.03527 \\
\hline & ounces (troy) & 0.03215 \\
\hline kilograms & pounds & 2.2046 \\
\hline metric tons & short tons & 1.1023 \\
\hline parts per million (ppm) & parts per billion (ppb) & 1,000 \\
\hline parts per million (ppm) & ounces per ton & 0.0292 \\
\hline parts per million (ppm) & grams/metric tons (tonnes) & 1.00 \\
\hline \multicolumn{3}{|c|}{ Length } \\
\hline miles & kilometers & 1.6093 \\
\hline yards & meters & 0.9144 \\
\hline \multirow[t]{3}{*}{ feet } & meters & 0.3048 \\
\hline & centimeters & 30.48 \\
\hline & millimeters & 304.80 \\
\hline \multirow[t]{2}{*}{ inches } & centimeters & 2.54 \\
\hline & millimeters & 25.4 \\
\hline kilometers & miles & 0.6214 \\
\hline \multirow{2}{*}{ meters } & yards & 1.0936 \\
\hline & feet & 3.2808 \\
\hline \multirow[t]{2}{*}{ millimeters } & feet & 0.00328 \\
\hline & inches & 0.03937 \\
\hline centimeters & inches & 0.3937 \\
\hline \multicolumn{3}{|c|}{ Area } \\
\hline square miles & square kilometers & 2.590 \\
\hline \multirow{2}{*}{ acres } & square meters & $4,046.873$ \\
\hline & hectares & 0.4047 \\
\hline square yards & square meters & 0.8361 \\
\hline square feet & square meters & 0.0929 \\
\hline \multirow[t]{2}{*}{ square inches } & square centimeters & 6.4516 \\
\hline & square millimeters & 645.16 \\
\hline square kilometers & square miles & 0.3861 \\
\hline \multirow[t]{3}{*}{ square meters } & acres & 0.000247 \\
\hline & square feet & 10.764 \\
\hline & square yards & 1.196 \\
\hline \multirow[t]{2}{*}{ hectares } & acres & 2.471 \\
\hline & square meters & $10,000.00$ \\
\hline square centimeters & square inches & 0.155 \\
\hline square millimeters & square inches & 0.00155 \\
\hline \multicolumn{3}{|c|}{ Volume } \\
\hline cubic yards & cubic meters & 0.7646 \\
\hline cubic feet & cubic meters & 0.02832 \\
\hline cubic inches & cubic centimeter & 16.3871 \\
\hline \multirow[t]{2}{*}{ cubic meters } & cubic yards & 1.3079 \\
\hline & cubic feet & 35.3145 \\
\hline cubic centimeters & cubic inches & 0.06102 \\
\hline gallons (U.S.) & liters & 3.7854 \\
\hline liters & gallons (U.S.) & 0.2642 \\
\hline milliliters & ounces (fluid) & 0.03381 \\
\hline ounces (fluid) & milliliters & 29.5735 \\
\hline
\end{tabular}

Temperature conversions:

From degrees Fahrenheit to degrees Celsius, subtract 32 and multiply by $5 / 9$.

From degrees Celsius to degrees Fahrenheit, multiply by $9 / 5$ and add 32 . 
APPENDIX H

Primary metals production in Alaska, 1880-1999

\begin{tabular}{|c|c|c|c|c|c|c|c|c|c|c|c|c|c|c|c|c|c|c|c|c|}
\hline \multirow[b]{2}{*}{ Year } & \multirow{2}{*}{\multicolumn{2}{|c|}{ Gold }} & \multirow{2}{*}{\multicolumn{2}{|c|}{ Silver }} & \multirow{2}{*}{\multicolumn{2}{|c|}{ Mercury }} & \multirow{2}{*}{\multicolumn{4}{|c|}{\begin{tabular}{lll} 
Antimony & \multicolumn{1}{c|}{ Tin } \\
(lb) (IS) & (lb) & (1S)
\end{tabular}}} & \multirow{2}{*}{\multicolumn{4}{|c|}{ Lead }} & \multirow{2}{*}{\multicolumn{2}{|c|}{ Platinum }} & \multirow{2}{*}{\multicolumn{2}{|c|}{ Copper }} & \multirow{2}{*}{\multicolumn{2}{|c|}{ Chromium }} \\
\hline & & & & & & & & & & & & & & & & & & & & \\
\hline $\begin{array}{l}1880 . \\
1899\end{array}$ & $1,153.889$ & 23.85 & 496,101 & 329.0 & .. & $\cdots$ &.. & $\cdots$ & .. & $\ldots$ & 250 & 17.0 & .. & .. & 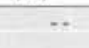 & $\cdots$ & .. & $\ldots$ & $\cdots$ & $\ldots$ \\
\hline 1900 & 395,030 & 8.17 & 73,300 & 45.5 & ... & .. & -. & & & .. & 40 & 3.4 & .. & .. & .. & .. & & & & .. \\
\hline 1901 & 335,369 & 6.93 & 47,900 & 28.6 & $\therefore$ & $\therefore$ & -. & $\cdots$ & $\cdots$ & & 40 & 3.4 & .. & .. & .. & .. & 250.600 & 0.04 & .. & -. \\
\hline 1902 & 400,709 & 8.28 & 92,000 & 48.5 & $\cdots$ & .. & -. & & 30,000 & 8.0 & 30 & 2.5 & $\ldots$ & & & & 360,000 & 0.04 & & -. \\
\hline 1903 & 420.069 & 8.68 & 143,600 & 77.8 & & -. & .. & .. & 50,000 & 14.0 & 30 & 2.5 & .. & & & .. & $1,200,000$ & 0.16 & & \\
\hline 1904 & 443,115 & 9.16 & 198.700 & 114.9 & .. & .. & .. & & 28.000 & 8.0 & 30) & 2.5 & .. & .. & & & $2,043,586$ & 0.28 & .. & .. \\
\hline 1905 & 756.101 & 15.63 & 132.174 & 80.2 & & $\therefore$ & & & 12,000 & 4.0 & 30 & 26 & ... & & & & $4,805,236$ & 0.75 & & \\
\hline 1906 & $1,066,030$ & 22.04 & 203,500 & 136.4 & & .. & -. & .. & 68.000 & 38.6 & 30 & 3.4 & .. & .. & .. & .. & 5.871 .811 & 1.13 & .. & \\
\hline 1907 & 936,043 & 19.35 & 149.784 & 98.8 & .. & $\therefore$ & .. & & 44,000 & 16.8 & 30 & 3,2 & .. & .. & .. & & $6,308,786$ & 1.26 & .. & .. \\
\hline 1908 & 933.290 & 19.29 & 135,672 & 71.9 & & .. & & & 50,000 & 15.2 & 40 & 3.4 & .. & & & & $4.585,362$ & 0.61 & & \\
\hline 1909 & 987,417 & 20.41 & 147,950 & 76.9 & .. & .. & .. & .. & 22.060 & 7.6 & 69 & 5.9 & -. & .. & .. & $\ldots$ & $4,124,705$ & 0.54 & .. & .. \\
\hline 1910 & 780,131 & 16.13 & 157,850 & 85.2 & .. & $\cdots$ & .. & $\cdots$ & 20,000 & 8.3 & 75 & 6.6 & ... & $\ldots$ & .. & .. & $4,241,689$ & 0.54 & -. & .. \\
\hline 1911 & 815,276 & 16.85 & 460.231 & 243.9 & .. & .. & *. & .. & 122.000 & 52.8 & 51 & 4.5 & .. & $\ldots$ & .. & $\cdots$ & $27,267.778$ & 3.40 & -. & .. \\
\hline 1912 & 829,436 & 17.14 & 515,186 & 316.8 & .. & .. & .. & ... & 260,000 & 119.6 & 45 & 4.1 & .. & .. & .. & .. & 29.230 .491 & 4.82 & .. & .. \\
\hline 1913 & 755.947 & 15.63 & 362.563 & 218.9 & .. & .. & .. & $\cdots$ & $100.000^{\mathrm{C}}$ & $44.1^{c}$ & 6 & 0.6 & .. & .. & .. & .. & $21,659.958$ & 3.35 & .. & .. \\
\hline 1914 & 762,596 & 15.76 & 394.805 & 218.3 & .. & .. & & .. & 208.000 & 66.6 & 28 & 1.3 & .. & .. & .. &.. & 21.450 .628 & 2.85 & .. & .. \\
\hline 1915 & 807.966 & 16.70 & $1,071,782$ & 543.3 & .. & .. & 520,000 & w & 204.000 & 78.8 & 437 & 41.1 & ... & .. & .. & $\cdots$ & 86.509 .312 & 15.14 & ... & .. \\
\hline 1916 & 834,068 & 17.24 & $1,379,171$ & 907.4 & .. & .. & 1.200 .000 & w & 278,000 & 121.0 & 820 & 113.2 & .. &.. & 8 & 0.7 & 119.654 .839 & 29.50 & .. & $\ddot{z}$ \\
\hline 1917 & 709,049 & 14.66 & $1,239.150$ & $1,020.6$ & .. & .. & 500.000 & w & 200,000 & 123.3 & 852 & 146.6 & .. & .. & 53 & 5.5 & $88,793,400$ & 24.40 & 1.100 & w \\
\hline 1918 & 458.641 & 9.48 & 847,789 & 847.8 & .. & .. & 540,000 & w & 136,000 & 118.0 & 564 & 80.1 & .. & .. & 284 & 36.6 & $69.224,951$ & 17.10 & 1,100 & w \\
\hline 1919 & 455.984 & 9.42 & 629.708 & 705.3 & .. & $\ldots$ & .. & $\ldots$ & 112.000 & 73.4 & 687 & 72.1 & & $\ldots$ & 569 & 73.7 & $47,220.771$ & 8.80 & & $\therefore$ \\
\hline 1920 & 404,683 & 8.37 & 953.546 & $1,039.7$ & .. & .. & ... & .. & 32,000 & 16.1 & 875 & 140.0 & .. & .. & 1,478 & 160.1 & $70,435,363$ & 13.00 & .. & .. \\
\hline 1921 & 390,558 & 8.07 & 761,085 & 761.1 & 45 & 1.5 & .. & .. & 8.000 & 2.4 & 759 & 68.3 & .. & .. & 40 & 2.7 & $57,011,597$ & 7.40 & .. & .. \\
\hline 1922 & 359.057 & 7.42 & 729,945 & 729.9 & . & $\cdots$ & .. & & 2,800 & 0.9 & 377 & 41.5 & .. & .. & 29 & 2.8 & $77,967,819$ & 10.50 & $\ldots$ & -. \\
\hline 1923 & 289,539 & 5.98 & 814,649 & 668.1 & & .. & & .. & 3,800 & 1.6 & 410 & 57.4 & -. & & .. & & $85,920,645$ & 12.60 & & \\
\hline 1924 & 304,072 & 6.29 & 669,641 & 448.6 & 2 & 0.3 & $\ddot{*}$ & i. & 14,000 & 7.1 & 631 & 100.9 & - & .. & 28 & 2.6 & $74,074,207$ & 9.70 & $\cdots$ & .. \\
\hline 1925 & 307.679 & 6.36 & 698.259 & 482.4 & 44 & 3.6 & w & w & 28.600 & 15,4 & 789 & 140.6 & -. & & 10 & 1.2 & $73,055,298$ & 10.30 & & .. \\
\hline 1926 & 324,450 & 6.70 & 605,190 & 377.0 & 22 & 1.7 & w & w & 16.000 & 10.4 & 778 & 124.4 & -. & & 3,570 & 274.5 & $67,778,000$ & 9.49 & & \\
\hline 1927 & 286,720 & 5.97 & 350,430 & 215.0 & .. & -. & -. & & 53,400 & 34.0 & 1,008 & 127.0 & . & $\ldots$ & & & $55,343,000$ & 7.25 & .. & .. \\
\hline 1928 & 331,140 & 6.85 & 351,730 & 187.0 & & $\because$ & & .. & 82,000 & 41.0 & 1.019 & 118 & $\ldots$ & & 120 & 9.0 & $41,421,000$ & 5.96 & & \\
\hline 1929 & 375,438 & 7.76 & 472,900 & 252.0 & 4 & 0.5 & .. & .. & 77,200 & 35.0 & 1,315 & 166 & $\ldots$ & .. & 475 & 32.0 & $40,570,000$ & 7.13 & ... & .. \\
\hline 1930 & 408.983 & 8.47 & 408,570 & 157 & .. & $\ldots$ & .. & $\ldots$ & 29,400 & 9.3 & 1,365 & 136 & ... & ... & .. & .. & 32.651 .000 & 4.24 & ... & .. \\
\hline 1931 & 459.000 & 9.51 & 352,000 & 102 & 15 & 1.2 & .. & .. & 8.200 & 2.0 & 1.660 & 126.0 & .. & .. & 393 & 14.0 & $22.614,000$ & 1.88 & ... & .. \\
\hline 1932 & 493.860 & 10.20 & 234,050 & & 8 & 0.5 & .. & .. & & & 1.260 & & .. & $\cdots$ & $\cdots$ &.. & $8,738.500$ & 0.55 & $\ldots$ & .. \\
\hline 1933 & 469.286 & 9.70 & 154,700 & 55.0 & ... & .. & .. &.. & 5,800 & 2.3 & 1.157 & 85. & .. & .. & 605 & 18.6 & 29,000 & 0.02 & $\therefore$ & .. \\
\hline 1934 & 537.281 & 8.78 & 154,700 & 100.0 & .. & $\cdots$ & .. & $\cdot \cdot$ & $8.200^{\mathrm{C}}$ & 4.3 & 839 & 62.1 & $\cdots$ & $\cdots$ & 2.555 & 85.6 & 121.000 & 0.06 & $\because$ & .. \\
\hline 1935 & 469,495 & 16.43 & 286,600 & 206.0 & .. & .. & .. & .. & 98.800 & 49.8 & 815 & 65.2 & .. & .. & 8.685 & 259.6 & $15,056,000$ & 1.25 & .. & $\cdots$ \\
\hline 1936 & 540,580 & & 484,306 & & .. & $\cdots$ & & .. & 226,000 & 105.0 & 941 & 86. & .. & $\ldots$ & 5.654 & 241.9 & $39,267,000$ & 3.72 & .. & .. \\
\hline 1937 & 627,940 & 21.98 & 494,340 & 382.0 & .. & $\cdots$ & 962.000 & 147.6 & $372.000^{c}$ & $202.3^{c}$ & 823 & 97.1 & ... &.. & 9.823 & 313.4 & 36.007 .000 & 4.74 & .. & -. \\
\hline 1938 & 662,000 & 23.17 & 479.853 & & 8 & 0.6 & 444,000 & 54.8 & 210.000 & 89.1 & 994 & 91.5 & .. &.. & 41,000 & 2.460 .0 & $29,760,000$ & 2.98 & .. & .. \\
\hline 1939 & 676.780 & 23.68 & 201.054 & & $\ldots$ & & 210,000 & 25.9 & 66,000 & 38.0 & 937 & 88.1 & ... & $\ldots$ & 33.900 & 2.034 .0 & 278,500 & 0.04 & .. & .. \\
\hline 1940 & 755,900 & 26.45 & 191.679 & 136.3 & $156^{\mathrm{c}}$ & 130.9 & 306,000 & 42.8 & 92,000 & 52.0 & 840 & 72.0 & .. & & 28,886 & 1.093 .0 & 110,000 & 0.02 & & .. \\
\hline 1941 & 692,314 & 24.23 & 199,700 & 142.0 & w & w & 774,000 & 87.3 & $93,600^{\mathrm{C}}$ & $61.0^{\mathrm{c}}$ & 742 & 58.0 & -. & $\cdots$ & 22,630 & 813.0 & 144,000 & 0.02 & .. & .. \\
\hline 1942 & 487,657 & 17.07 & 135.200 & 96.0 & w & w & 316,000 & 41.0 & 5,600 & 2.5 & 523 & 44.0 & .. & -. & 22,000 & 779.0 & 48,000 & 0.01 & & \\
\hline 1943 & 99,583 & 3.49 & 31,700 & 22.0 & 786 & 153.4 & 368,000 & 33.3 & $2,000^{\mathrm{c}}$ & $1.0^{c}$ & 200 & 22.0 & .. & & 27,900 & $1,020.0$ & 54,000 & 0.01 & 5.564 & 186.3 \\
\hline 1944 & 49,296 & 1.73 & 15,240 & 10.8 & 841 & 165.0 & 70,080 & 30,0 & .. & .. & 44 & 5.8 & .. & & 33,616 & $2,017.0$ & 4,000 & 0.01 & 1.845 & 64.6 \\
\hline 1945 & 68.117 & 2.38 & 9,983 & 6.2 & 275 & 180.0 & w & $w$ & .. & & 11 & 1.8 & .. & .. & 22,949 & $1,377.0$ & 10,000 & 0.01 & .. & .. \\
\hline 1946 & 226,781 & 7.93 & 41,793 & 26.3 & 699 & 68.7 & w & w & .. & & 115 & 25.0 & .. & & 22,882 & $1,418.7$ & 4,000 & 0.01 & . & .. \\
\hline 1947 & 279.988 & 9.79 & 66.150 & 46.3 & 127 & 10.6 & 52,000 & 16.1 & 2,000 & 2.2 & 255 & 76 & 226 & 0.15 & 13,512 & 1,351.2 & 24,000 & 0.06 & .. & .. \\
\hline 1948 & 248.395 & 8.69 & $\begin{array}{l}67,341 \\
36056\end{array}$ & 58.7. & 108 & 7.8 & 88,000 & 29.3 & $\begin{array}{r}10,000 \\
\end{array}$ & 10.8 & 317 & 88.9 & 226 & 0.15 & 13.741 & $1,209.2$ & 28,000 & 0.07 & .. & .. \\
\hline 1949 & 229,416 & 8.03 & 36,056 & 32.4 & 102 & 7.9 & 88.000 & 31.31 & 114,000 & 100.8 & 49 & 11.2 & 226 & 0.15 & 17,169 & 1.545 .2 & 7,700 & 0.02 & .. & \\
\hline
\end{tabular}


APPENDIX H

continued

\begin{tabular}{|c|c|c|c|c|c|c|c|c|c|c|c|c|c|c|c|c|c|c|c|c|}
\hline \multirow[b]{2}{*}{ Year } & \multicolumn{2}{|c|}{ Gold } & \multicolumn{2}{|c|}{ Silver } & \multicolumn{2}{|c|}{ Mercury } & \multicolumn{2}{|c|}{ Antimony } & \multicolumn{2}{|c|}{ Tin } & \multicolumn{2}{|c|}{ Lead } & \multicolumn{2}{|c|}{ Zine } & \multicolumn{2}{|c|}{ Platinum } & \multicolumn{2}{|c|}{ Copper } & \multicolumn{2}{|c|}{ Chromium } \\
\hline & (oz) & (mS) & $(o z)$ & (I\$) & (flask $)^{b}$ & (15) & (b) & (15) & (b) & (15) & (tons) & (15) & (tons) & (IS) & (oz) & (IS) & & (mS) & (tons) & (I\$) \\
\hline 1950 & 289,285 & 10.13 & 52.638 & 48.0 & w & w & w & w & 158,000 & 170.3 & 144 & 27.5 & . & $\ldots$ & w & w & 12,000 & 0.03 & $\ldots$ & .. \\
\hline 1951 & 239,628 & 8.38 & 32,870 & 29.8 & 28 & w & $1,718,000$ & $2,061.6$ & 138,000 & 198.0 & 21 & 7.2 & $\cdots$ & $\cdots$ & w & w & 2,000 & 0.01 & -. & - \\
\hline 1952 & 240,571 & 8.42 & 31,825 & 28.7 & 40 & w & 740,000 & 1.406 .0 & 180,000 & 243.9 & 1 & 0.3 & .. & .. & w & w & . & & w & w \\
\hline 1953 & 253,771 & 8.88 & 35,387 & 32.1 & 1.023 & 270.0 & & w & 98.000 & 105.9 & .. & .. & .. & .. & 17.489 & 1.696 .4 & .. & .. & w & w \\
\hline 1954 & 248.511 & 8.70 & 33.694 & 31.8 & 1.046 & 276.0 & .. & .. & 398.000 & 409.9 & ... & 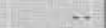 & .. & .. & 18.790 & 1.6159 & 8.000 & 0.02 & 2.953 & 208.0 \\
\hline 1955 & 249,294 & 8.73 & 33,693 & 30.4 & 43 & 12.0 & .. & & 172,000 & 182.5 & 1 & 0.3 & -. & .. & 17.253 & 1.466 .5 & 2,000 & 0.01 & 7.082 & 625.3 \\
\hline 1956 & 204,300 & 7.33 & 26.700 & 24.1 & 3.414 & 837.0 & 134,400 & 150.0 & .. & .. & i & 0.3 & .. & .. & 17.934 & 1.829 .3 & .. & $\ldots$ & 7.200 & 711.5 \\
\hline 1957 & 215.467 & 7.54 & 28.862 & 26.0 & 5.461 & 1.349 .0 & 71.120 & 80.0 & .. & .. & 9 & 3.0 & .. & .. & 15.479 & $1,377.6$ & .. & & 4,207 & 431.0 \\
\hline 1958 & 186,000 & 6.53 & 24,000 & 22.0 & 3.380 & 774.0 & .. & .. & .. &.+ & .. & .. & .. & .. & 10.284 & 647.9 & 10,000 & 0.03 & .. & .. \\
\hline 1959 & 171,000 & 5.99 & 22,000 & 20.0 & 3.750 & 852.0 & .. & .. & .. & $\ldots$ & .. & .. & .. & & 10,698 & 770.3 & 72,000 & 0.04 & .. & .. \\
\hline 1960 & 180,000 & 6.30 & 23,000 & 21.0 & 4,450 & 938.0 & w & w & .. & .. & .. & .. & .. & $\cdots$ & 13.352 & $1,054,8$ & 82,000 & 0.04 & .. & \\
\hline 1961 & 114,228 & 3.99 & .. & .. & 4,080 & 816.0 & .. & .. & .. & .. & .. & -. & .. & $\cdots$ & 16,133 & $1,274.5$ & 184.000 & 0.06 & $\cdots$ & .. \\
\hline 1962 & 165,142 & 5.78 & .. & .. & 3,843 & 711.0 & .. & .. & & $\cdots$ & . & .. & & & 12,520 & 951.5 & . & .. & .. & .. \\
\hline 1963 & 99,000 & 3.48 & 6.100 & 9.0 & 400 & 76.0 & w & w & .. & .. & 5 & 1.1 & & & 12,322 & 961.1 & & .. & .. & \\
\hline 1964 & 58,000 & 2.05 & 7,200 & 6.0 & 303 & 95.0 & 46,400 & 60.3 & & .. & $\therefore$ & .. & $\cdots$ & ... & 13,010 & 1.522 .2 & 22,000 & 0.01 & .. & .. \\
\hline 1965 & 43,000 & 1.51 & 5.000 & 6.0 & 180 & 104.0 & 46.400 & 60.3 & .. & .. & 14 & 4.0 & & & 10.365 & $1,368.2$ & 64,000 & 0.03 & .. & \\
\hline 1966 & 27,325 & 0.96 & 7.000 & 9.0 & 185 & 101.0 & 16,000 & 19.2 & .. & .. & 19 & 4.3 & .. & .. & 9,033 & $1,273.7$ & .. & $\cdots$ & .. & .. \\
\hline 1967 & 22,948 & 0.80 & 6,000 & 9.0 & 161 & 79.0 & 20,000 & 22.0 & & .. & $\therefore$ & .. & & & 7.888 & 1.238 .4 & w & w & .. & .. \\
\hline 1968 & 21.000 & 0.81 & 3,000 & 6.5 & 156 & 78.0 & 6,000 & 6.0 & .. & .. & $\because$ & $\because$ & $\cdots$ & & 8,433 & 1.652 .9 & .. & .. & .. & -. \\
\hline 1969 & 21,227 & 0.88 & 2,000 & 4.2 & 238 & 100.0 & 94,000 & 100.0 & .. & $\ldots$ & 2 & 0.5 & .. & .. & 8,500 & $2,321.2$ & & & .. & \\
\hline 1970 & 38,400 & 1.38 & 4,000 & 7.0 & 3,100 & $1,260.0$ & 365,000 & 410.0 & & & .. & .. & .. & $\cdots$ & 6,015 & 925.1 & W & w & $\cdots$ & .. \\
\hline 1971 & 34,000 & 1.36 & 2.000 & 4.0 & 675 & 285.0 & 68,000 & 74.0 & 34,000 & 47.0 & .. & .. & .. & 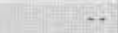 & 5.407 & 625.6 & .. & . & .. & .. \\
\hline 1972 & 8.639 & 0.56 & 1.000 & 2.0 & 125 & 44.0 & 160.000 & 185.0 & w & w & .. & 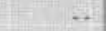 & .. & .. & 6,478 & 985.5 & .. & .. & .. & .. \\
\hline 1973 & 15,000 & 1.86 & 13.200 & 22.0 & 70 & 52.5 & 420,000 & 515.0 & 10,000 & 12.0 & 6 & 2.0 & .. & $\cdots$ & 5.524 & 964.5 & .. & .. & .. & .. \\
\hline 1974 & 16,000 & & 1.500 & 3.5 & 70 & 52.5 & 80,000 & 95.0 & w & w & .. & $\ldots$ & $\ldots$ & $\ldots$ & 4,351 & 1.067 .0 & $\ldots$ & .. & .. & .. \\
\hline 1975 & 14.980 & & & 25.0 & .. & & 120.000 & 145.0 & 22,000 & 60.0 & .. & .. & .. & .. & 3,726 & 623.3 & .. & .. & .. & .. \\
\hline 1976 & 22,887 & 6.90 & 6,500 & 24.0 & .. & $\cdots$ & 160,000 & 165.0 & w & w & 14 & 6.0 & .. & $\ldots$ & 3.212 & 515.2 & $\cdots$ & .. & $8,000^{C}$ & $1.200 .0^{e}$ \\
\hline 1977 & 50,000 & 7.80 & 8.000 & 20.0 & .. & .. & w & w & w & w & .. & .. & .. &.. & 6.891 & $1,119.8$ & .. & $\ldots$ & .. & .. \\
\hline 1978 & .000 & 12. & & & .. & .. & w & w & w & w & .. & .. & .. & ... & .. & & .. & .. & .. & .. \\
\hline 1979 & & & 6.500 & 93. & .. & .. & 100.000 & 125.0 & 100.000 & 830.0 & $\ldots$ & .. & .. &.. & .. & .. & $\cdots$ & .. & $\ldots$ & .. \\
\hline 1980 & 75,000 & & 7,500 & & .. & .. & .. & .. & 120,000 & 984.0 & 31 & 29.0 & .. & $\ldots$ & $\ldots$ & .. & .. & .. & .. & .. \\
\hline 1981 & 134,200 & 55.2 & 13,420 & & w & w & .. & .. & 106,000 & & $\ldots$ & $\ldots$ & .. & .. & 900 & 200.0 & .. & .. & .. & .. \\
\hline 1982 & 175,000 & 69.9 & 22,000 & & .. & .. & .. & $\cdots$ & 198,000 & $1,365.0$ & & .. & .. & & w & w & .. & .. & $\ldots$ & .. \\
\hline 1983 & 169,000 & 67.60 & 33,200 & 332. & . & & 22,400 & 45.0 & 215,000 & I, 100.0 & $\ldots$ & $\ldots$ & .. & $\ldots$ & w & w & .. & .. & .. & .. \\
\hline 1984 & 175,000 & 62.13 & 20,000 & & 5 & 1.5 & 135,000 & 225.8 & 225,000 & & & .. & .. & & w & w & $\ldots$ & & $\cdots$ & \\
\hline 1985 & 190,000 & 61. & 28.500 & 17 & 27 & 10.0 & 65,000 & 98.0 & 300,000 & 65 & .. & .. & .. & & .. & & $\cdots$ & .. & . & .. \\
\hline 1986 & 160.000 & 60 & 24,000 & 13 & 12 & 2.8 & 45,000 & 67.5 & 340,000 & 89 & & .. & .. & .. & w & w & $\cdots$ & .. & $\cdots$ & .. \\
\hline 1987 & 229.707 & 104.51 & 54,300 & & .. & .. & .. & .. & 288,000 & 460.0 & & .. & .. & & w & w & & & $\ldots$ & \\
\hline 1988 & 265.500 & 112.84 & 47,790 & 282.0 & w & w & .. & $\therefore$ & 300,000 & 950.0 & .. & .. & .. & $\ldots$ & 25 & 13.8 & .. & .. & $\ldots$ & .. \\
\hline 1989 & 284,617 & 108.70 & $5,211,591$ & 27.300 .0 & .. & & .. & NR & 194,000 & 672.0 & 9,585 & $7,700.0$ & 19,843 & $29,400.0$ & & & $\ldots$ & .. & .. & .. \\
\hline 1990 & 231.700 & 89.20 & $10,135,000$ & 50.675 .0 & .. & .. & .. & .. & 57,000 & 200.0 & 44.220 & 30.954 .0 & 181,200 & $253,680.0$ & .. & .. & .. & .. & .. & .. \\
\hline 1991 & 243,900 & & & & & & & & 6.800 & 22.1 & 69.591 & $33,403.7$ & 278,221 & 278.221 .0 & 15 & 5.3 & .. & .. & .. & .. \\
\hline 1992 & 262.530 & 88 & 55 & & .. & .. & .. & .. & 1.500 & 5. & & & 274.507 & 301.957 .7 & . & 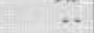 & .. & .. & .. & .. \\
\hline 1993 & 191,265 & & 8 & & .. & .. & .. & .. & 21,000 & 50.6 & 38,221 & & 8.769 & & 3 & 1.2 & .. & .. & .. & .. \\
\hline 1994 & 182,1 & & 00 & & .. & .. & .. & .. & .. & .. & 36,447 & & 329.003 & & 5 & 2.1 & .. & .. & .. & .. \\
\hline 1995 & 141,882 & & 25.730 & & .. & .. & .. & .. & .. & $\cdots$ & 58,0 & & 950 & & 1 & 0.4 & .. & .. & .. & .. \\
\hline 1996 & 161.565 & 62.62 & 3.676 .000 & $19,078.0$ & .. & ... & .. & .. & .. & .. & 70.086 & 52.2 & 366,780 & & 2 & 0.8 & 780,000 & 0.80 & .. & .. \\
\hline 1997 & 590,516 & 207.29 & $14,401,165$ & $70,710,0$ & .. & .. & .. & .. & .. & . & 88.560 & $49,593.0$ & 419.097 & 494.888 .0 & .. & $\cdots$ & $3.440,000$ & 3.54 & .. & .. \\
\hline 1998 & 594.191 & 174.62 & $14.856,000$ & $82,154.0$ & .. & .. & .. & .. & .. & .. & 102,887 & 49.386 .0 & 549.348 & $505,400.0$ & .. & .. & $3.800,000$ & 2.85 & .. & .. \\
\hline 1999 & 517,890 & 144.26 & $16.467,000$ & 85.628 .0 & $\ldots$ & $\ldots$ & .. & .. & .. & .. & 125.208 & 57.596 .0 & 643,642 & 630.769 .0 & .. & & $4.200,000$ & 3.00 & .. & .. \\
\hline Other & & & & & 1,438 & .. & .. & -. & .. & & & & & & 71,946 & 17.091 .9 & .. & & .. & -. \\
\hline TOTAL. & $35,242,310$ & $2,588.73$ & $111,809,918$ & $467,294.0$ & 40,945 & 9,910.5 & $11,070,800$ & $6,655.1$ & $7,287,700$ & $12,523.5$ & 737,867 & $389,211.9$ & $3,691,038$ & $3,734,133,6$ & $668,548^{d}$ & $65,815.7$ & $1,390,013,932$ & 238.22 & 39,051 & $3,426.7$ \\
\hline $\begin{array}{l}\text { From pl } \\
\text { b76-lb fl } \\
\text { cNot trac }\end{array}$ & ished and & npubli & ed state ar & $\mathrm{d}$ federa & cum & & $\begin{array}{l}{ }^{\mathrm{d}} \text { Crude pla } \\
575,000 \text { o: } \\
\text { W = Withl }\end{array}$ & num; & tal prod & tion of & efined & etal is : & & $\begin{array}{l}\cdots=\mathrm{Not} \\
\mathrm{t} \mathrm{S}=\mathrm{Tho} \\
\mathrm{mS}=\mathrm{M}\end{array}$ & $\begin{array}{l}\text { reported } \\
\text { usand do } \\
\text { illion doll }\end{array}$ & & & & & \\
\hline
\end{tabular}




\section{APPENDIX I}

Production of industrial minerals, coal, and other commodities in Alaska, 1880-1999

\begin{tabular}{|c|c|c|c|c|c|c|c|c|c|}
\hline \multirow[b]{2}{*}{ Year } & \multicolumn{2}{|c|}{ Coal } & \multicolumn{2}{|c|}{ Sand and gravel } & \multicolumn{2}{|c|}{ Rock $^{\mathrm{a}}$} & \multicolumn{2}{|c|}{ Barite } & \multirow{2}{*}{$\begin{array}{c}\text { Other }^{b} \\
\$\end{array}$} \\
\hline & s. tons & $\mathrm{mS}$ & s. tons & $\mathrm{mS}$ & s. tons & $\mathrm{mS}$ & s. tons & t\$ & \\
\hline $1880-1899^{c}$ & 19,429 & 0.14 & .. & .. & 7,510 & 0.04 & .. & .. & .. \\
\hline 1900 & $1,200^{\mathrm{d}}$ & $0.02^{\mathrm{d}}$ & $\cdots$ & $\cdots$ & 510 & 0.01 & $\cdots$ & $\cdots$ & $\cdots$ \\
\hline 1901 & $1,300^{\mathrm{d}}$ & $0.02^{\mathrm{d}}$ & $\cdots$ & - & 700 & 0.01 & -. & $\cdots$ & 500 \\
\hline 1902 & $2,212^{\mathrm{d}}$ & $0.02^{\mathrm{d}}$ & - & - & 800 & 0.01 & - & - & 255 \\
\hline 1903 & 1,447 & 0.01 & - & - & 920 & 0.01 & -. & - & 389 \\
\hline 1904 & 1,694 & 0.01 & -. & $\cdots$ & 1,080 & 0.02 & -. & - & 2,710 \\
\hline 1905 & 3,774 & 0.02 & -. & - & 970 & 0.02 & - & $\cdots$ & 740 \\
\hline 1906 & 5,541 & 0.02 & $\cdots$ & $\cdots$ & 2,863 & 0.03 & -. & $\cdots$ & 19,965 \\
\hline 1907 & 10,139 & 0.05 & & $\cdots$ & 3,899 & 0.03 & .. & $\cdots$ & 54,512 \\
\hline 1908 & $3,107^{\mathrm{d}}$ & $0.01^{\mathrm{d}}$ & -. & $\cdots$ & 2,176 & 0.03 & -. & $\cdots$ & 81,305 \\
\hline 1909 & 2,800 & 0.02 & .. & .. & 1.400 & 0.01 & $\ldots$ & .. & 86,027 \\
\hline 1910 & $1,000^{\mathrm{d}}$ & $0.01^{d}$ & $\cdots$ & .. & W & W & $\ldots$ & .. & 96,408 \\
\hline 1911 & $900^{d}$ & $0,01^{d}$ & $\cdots$ & .. & W & W & .. & . & 145,739 \\
\hline 1912 & $355^{\mathrm{d}}$ & $0.01^{d}$ & -. & .. & w & w & $\ldots$ & .. & 165,342 \\
\hline 1913 & 2,300 & 0.01 & . & . & W & W & $\cdots$ & . & 286,277 \\
\hline 1914 & 1,190 & 0.01 & .. & $\ldots$ & W & W & .. & . & 199,767 \\
\hline 1915 & 1,400 & 0.03 & .. & .. & W & W & . & .. & 205,061 \\
\hline 1916 & 12,676 & 0.05 & $\cdots$ & -. & W & W & .. & .. & 326,731 \\
\hline 1917 & 54,275 & 0.27 & . & $\ldots$ & W & W & -. & .. & 203,971 \\
\hline 1918 & 75,816 & 0.41 & $\cdots$ & .. & W & W & . & $\cdots$ & 171,452 \\
\hline 1919 & 60.894 & 0.35 & $\ldots$ & .. & 50,014 & 0.29 & .. & .. & 214,040 \\
\hline 1920 & 61,111 & 0.36 & - & .. & 37,044 & 0.27 & $\cdots$ & $\cdots$ & 372,599 \\
\hline 1921 & 76,817 & 0.49 & $\cdots$ & - & 59,229 & 0.31 & - & . & 235,438 \\
\hline 1922 & 79,275 & 0.43 & - & -. & 54,251 & 0.30 & $\cdots$ & . & 266,296 \\
\hline 1923 & 119.826 & 0.76 & - & . & 83,586 & 0.41 & -. & . & 229,486 \\
\hline 1924 & 99,663 & 0.56 & - & -. & 35,294 & 0.26 & $\cdots$ & . & 348,728 \\
\hline 1925 & 82,868 & 0.40 & $\cdots$ & . & 32,193 & 0.19 & - & . & 454,207 \\
\hline 1926 & 87.300 & 0.46 & $\cdots$ & $\cdots$ & 33,283 & 0.20 & - & . & 423,000 \\
\hline 1927 & 104,300 & 0.55 & $\cdots$ & $\cdots$ & 41,424 & 0.22 & - & $\cdots$ & . \\
\hline 1928 & 126,100 & 0.66 & -. & - & 63,347 & 0.31 & -. & $\cdots$ & $\cdots$ \\
\hline 1929 & 100,600 & 0.53 & .. & -. & 54,766 & 0.26 & - & $\ldots$ & 194,000 \\
\hline 1930 & 120,100 & 0.63 & .. & .. & 66,234 & 0.33 & $\cdots$ & $\cdots$ & 157,300 \\
\hline 1931 & 105,900 & 0.56 & .. & . & 59,175 & 0.29 & . & . & 108,000 \\
\hline 1932 & 102,700 & 0.53 & .. & .. & 54,167 & 0.27 & $\cdots$ & .. & 223,400 \\
\hline 1933 & 96,200 & 0.48 & .. & .. & 56,291 & 0.28 & .. & $\cdots$ & . \\
\hline 1934 & 107,500 & 0.45 & . & . & 64,234 & 0.36 & - & $\cdots$ & 46,155 \\
\hline 1935 & 119,425 & 0.50 & . & .. & 74,049 & 0.38 & .. & .. & 46,755 \\
\hline 1936 & 136,593 & 0.57 & -. & - & 76,379 & 0.38 & .. & $\ldots$ & 45,807 \\
\hline 1937 & 131,600 & 0.55 & .. & .. & 50,057 & 0.25 & $\cdots$ & . & 147,048 \\
\hline 1938 & 159,230 & 0.62 & . & - & 189,090 & 0.21 & $\cdots$ & $\cdots$ & 125,302 \\
\hline 1939 & 143,549 & 0.60 & 42.332 & 0.02 & .. & .. & .. & . & .. \\
\hline 1940 & 170,174 & 0.88 & 515,011 & 0.10 & $\cdots$ & $\cdots$ & $\cdots$ & $\cdots$ & $\ldots$ \\
\hline 1941 & 241,250 & 0.97 & 530,997 & 0.09 & $\cdots$ & -. & - & $\cdots$ & $1,367,000$ \\
\hline 1942 & 246,600 & 0.99 & W & W & -. & .. & .. & . & $1,124,000$ \\
\hline 1943 & 289,232 & 1.84 & W & W & $\cdots$ & - & -. & . & - \\
\hline 1944 & 352,000 & 2.37 & 712,496 & 0.50 & - & -. & -. & . & $2,350,309$ \\
\hline 1945 & 297,644 & 1.87 & W & W & $\cdots$ & - & - & - & $5,910,704$ \\
\hline 1946 & 368,000 & 2.36 & W & W & $\ldots$ & . & . & $\cdots$ & $2,005,241$ \\
\hline 1947 & 361,220 & 2.55 & W & W & 219,000 & 1.00 & $\cdots$ & $\cdots$ & $5,927,319$ \\
\hline 1948 & 407.906 & 2.79 & W & W & 67,341 & 0.33 & $\cdots$ & $\cdots$ & $1,257,699$ \\
\hline 1949 & 455,000 & 3.60 & W & W & W & W & - & .. & $7,181,886$ \\
\hline 1950 & 421,455 & 3.03 & $3,050,020$ & 2.38 & W & W & $\cdots$ & $\cdots$ & $2,100,000$ \\
\hline 1951 & 494,333 & 3.77 & $6,818,000$ & 3.54 & W & W & . & .. & $3,600,000$ \\
\hline 1952 & 648,000 & 5.77 & $6,817,800$ & 3.54 & W & W & -. & $\cdots$ & $9,052,000$ \\
\hline 1953 & 861,471 & 8.45 & $7,689,014$ & 5.08 & 47,086 & 0.17 & .. & $\cdots$ & $1,231,350$ \\
\hline 1954 & 666,618 & 6.44 & $6,639,638$ & 6.30 & 283,734 & 0.47 & . & $\cdots$ & $1,572,150$ \\
\hline 1955 & 639,696 & 5.76 & $9,739,214$ & 8.24 & 265,740 & 0.29 & - & . & $1.552,427$ \\
\hline 1956 & 697,730 & 6.37 & $9,100,000$ & 8.30 & 50,000 & 0.02 & .. & .. & $1,551,500$ \\
\hline 1957 & 842,338 & 7.30 & $6,096,000$ & 8.79 & 528,000 & 1.95 & . & .. & $2,751,000$ \\
\hline 1958 & 759,000 & 6.93 & $4,255,000$ & 3.87 & 615,000 & 2.07 & -. & -. & 695,000 \\
\hline 1959 & $602.000^{d}$ & $5.88^{d}$ & 5.600 .000 & 5.10 & 54,000 & 0.20 & .. & $\cdots$ & 1.338 .000 \\
\hline
\end{tabular}




\begin{tabular}{|c|c|c|c|c|c|c|c|c|c|}
\hline \multirow[b]{2}{*}{ Year } & \multicolumn{2}{|c|}{ Coal } & \multicolumn{2}{|c|}{ Sand and gravel } & \multicolumn{2}{|l|}{ Rock $^{\mathrm{a}}$} & \multicolumn{2}{|c|}{ Barite } & \multirow{2}{*}{$\begin{array}{l}\text { Other } \\
\$\end{array}$} \\
\hline & s. tons & $\mathrm{m \$}$ & s. tons & $\mathrm{m} \$$ & s. tons & $\mathrm{ms}$ & s. tons & t\$ & \\
\hline 1960 & $669,000^{\mathrm{d}}$ & $5.95^{\text {d }}$ & $5,892,000$ & 5.35 & 80,000 & 0.30 & - & $\cdots$ & 975,000 \\
\hline 1961 & $650,000^{d}$ & $5.87^{d}$ & $5,241,000$ & 4.19 & - & - & $\cdots$ & $\cdots$ & . \\
\hline 1962 & $675,000^{d}$ & $6.41^{d}$ & $5,731,000$ & 5.36 & $\cdots$ & - & - & $\cdots$ & . \\
\hline 1963 & 853,000 & 5.91 & $16,926,000$ & 22.01 & W & W & W & W & $2,589,000$ \\
\hline 1964 & 745,000 & 5.01 & $26,089,000$ & 18.49 & W & W & w & W & $4,912,000$ \\
\hline 1965 & $860,000^{d}$ & $5.88^{\mathrm{d}}$ & $29,959,000$ & 33.93 & W & W & W & W & $5,296,000$ \\
\hline 1966 & 927,000 & 6.95 & $17,457,000$ & 21.79 & W & W & 44,000 & 350.0 & $6,167,000$ \\
\hline 1967 & 930,000 & 7.18 & $22,300,000$ & 26.25 & W & W & W & W & $4,924,000$ \\
\hline 1968 & $812,000^{d}$ & $5.03^{\mathrm{d}}$ & $17,515,000$ & 20.73 & W & W & 91,000 & W & $4,117,000$ \\
\hline 1969 & $728,000^{\mathrm{d}}$ & $4.65^{\text {d }}$ & $16,205,000$ & 18.62 & $1.954,000$ & 3.90 & 90,000 & 850.0 & $5,163,000$ \\
\hline 1970 & $786,000^{\mathrm{d}}$ & $5.28^{\mathrm{d}}$ & $20,375,000^{d}$ & $26.07^{d}$ & $6,470,000$ & 10.01 & $134,000^{d}$ & $1,875.0$ & $7,994,000$ \\
\hline 1971 & $748,000^{\mathrm{d}}$ & $5.05^{d}$ & $26,391,000$ & 41.99 & $2,658,000$ & 5.07 & $102,000^{d}$ & $1,075.0$ & . \\
\hline 1972 & $720,000^{d}$ & $6.26^{d}$ & $14,187,000$ & 15.21 & 652,000 & 3.01 & W & W & .. \\
\hline 1973 & $700,000^{d}$ & $6.23^{d}$ & $19,350,000$ & 19.01 & $5,967,000$ & 12.00 & 112,000 & $1,792.0$ & $12,846,000$ \\
\hline 1974 & 700,000 & 7.34 & $118,740,000^{d}$ & $240.94^{d}$ & $5,484,000$ & 12.95 & 110,000 & $1,895.0$ & $14,495,000$ \\
\hline 1975 & 766,000 & 7.81 & $48,145,000$ & 95.78 & $8,877,000$ & 26.65 & $2,000^{d}$ & 30.0 & $12,731,000$ \\
\hline 1976 & 705,000 & 8.00 & $74,208,000^{\mathrm{d}}$ & $204.73^{d}$ & $6,727,000$ & 20.09 & W & W & $14,019,000$ \\
\hline 1977 & $780,000^{d}$ & $12.00^{\mathrm{d}}$ & $66,126,000$ & 134.25 & $4,008,000$ & 17.47 & - & - & $14,486,000$ \\
\hline 1978 & 750,000 & 15.00 & $51,100,000$ & 122.00 & $3,437,000$ & 14.65 & 22,000 & 750.0 & . \\
\hline 1979 & 750,000 & 16.00 & $50,900,000$ & 104.90 & $3,650,000$ & 15.45 & 20,000 & 800.0 & 930,000 \\
\hline 1980 & 800,000 & 16.00 & $40,000,000$ & 86.00 & $3,700,000$ & 15.40 & 50,000 & $2,000.0$ & 97,500 \\
\hline 1981 & 800,000 & 17.60 & $46,000,000$ & 88.20 & $4,200,000$ & 19.30 & - & - & 256,000 \\
\hline 1982 & 830,000 & 18.00 & $45,000,000$ & 91.00 & $3,400,000$ & 15.60 & $\cdots$ & $\cdots$ & 150,000 \\
\hline 1983 & 830,000 & 18.00 & $50,000,000$ & 105.00 & $5,270,000$ & 25.00 & $\cdots$ & - & 242,000 \\
\hline 1984 & 849,161 & 23.75 & $27,000,000$ & 95.00 & $2,700,000$ & 16.00 & $\cdots$ & $\cdots$ & 875,875 \\
\hline 1985 & $1,370,000$ & 39.73 & $28,184,080$ & 112.06 & $2,500,000$ & 12.00 & $\cdots$ & $\cdots$ & 559,000 \\
\hline 1986 & $1,492,707$ & 40.10 & $20,873,110$ & 75.76 & $4,200,000$ & 20.32 & - & $\cdots$ & 384,800 \\
\hline 1987 & $1,508,927$ & 42.35 & $16,696,374$ & 42.66 & $1,805,000$ & 11.62 & - & $\cdots$ & 388,400 \\
\hline 1988 & $1,551,162$ & 44.30 & $17,264,500$ & 48.75 & $3,600,000$ & 24.65 & $\cdots$ & $\cdots$ & 389,000 \\
\hline 1989 & $1,452,353$ & 41.46 & $14,418,000$ & 39.88 & $2,914,000$ & 20.34 & - & $\cdots$ & $1,492,000$ \\
\hline 1990 & $1,576,000$ & 44.99 & $15,013,500$ & 40.82 & $3,200,000$ & 22.10 & . & $\cdots$ & 400,000 \\
\hline 1991 & $1,540,000$ & 39.00 & $14,160,011$ & 45.45 & $3,000,000$ & 22.50 & $\cdots$ & $\cdots$ & 462,000 \\
\hline 1992 & $1,531,800$ & 38.30 & $14.599,746$ & 42.20 & $2,900,000$ & 22.97 & $\cdots$ & .. & 430,000 \\
\hline 1993 & $1,586,545$ & 38.10 & $13,162,402$ & 40.64 & $3,561,324$ & 26.21 & $\cdots$ & $\cdots$ & 465,000 \\
\hline 1994 & $1,490,000$ & 36.75 & $13,518,321$ & 40.95 & $3,843,953$ & 27.04 & .. & .. & 459,500 \\
\hline 1995 & $1,640,000$ & 41.30 & $9,847,550$ & 30.89 & $2,811,152$ & 22.13 & $\cdots$ & $\cdots$ & 182,500 \\
\hline 1996 & $1,481,000$ & 38.00 & $9,890,463$ & 32.20 & $3,000,045$ & 23.56 & $\cdots$ & $\cdots$ & 200,000 \\
\hline 1997 & $1,446,000$ & 38.05 & $13,800,000$ & 51.91 & $3,200,000$ & 20.00 & $\ldots$ & .. & 217,000 \\
\hline 1998 & $1,339,000$ & 35.23 & $12,363,450$ & 57.28 & $1,636.200$ & 14.04 & .. & .. & 215.000 \\
\hline 1999 & $1,560,000$ & 41.05 & $10,600,000$ & 52.42 & $1,640,000$ & 18.01 & . & $\cdots$ & . \\
\hline Other ${ }^{d}$ & $\cdots$ & $\cdots$ & $\cdots$ & $\cdots$ & $2,300,000^{\mathrm{e}}$ & W & 79,000 & W & $\cdots$ \\
\hline TOTAL $^{f}$ & $54,174,000$ & 931.98 & $1,152,834,000$ & $2,456.52$ & $118,733,000$ & 552.83 & 856,000 & $11,417.00$ & $177,761,872$ \\
\hline
\end{tabular}

aBuilding-stone production figures for 1880-1937 are for the southcentral and interior regions of Alaska only.

'Includes 2.4 million $\mathrm{lb} \mathrm{U}_{3} \mathrm{O}_{8}$ (1955-71); 505,000 tons gypsum (1905-26); 286,000 lb WO (intermittently 1916-80); 94,000 lb asbestos (1942-44); $540,000 \mathrm{lb}$ graphite (1917-18 and 1942-50); and undistributed amounts of zinc, jade, peat, clay, soapstone, miscellaneous gemstones, and other commodities (1880-1993).

cProduction not traceable by year.

${ }^{\mathrm{d}}$ When state (territorial) and federal figures differ significantly, state figures are used. Figures for sand and gravel production in 1974 show state estimates $(118,740,000 \mathrm{~s}$. tons; $240.94 \mathrm{~m} \$)$ and federal $(42,614,000 \mathrm{~s}$. tons; $88.96 \mathrm{m \$})$. The federal estimate was not added to total production. eMarble quarried on Prince of Wales Island, southeastern Alaska (1900-41).

fRounded to nearest 1.000 ton. $\mathrm{mS}=$ Million dollars .

$\mathrm{t} \$=$ Thousand dollars

- = Not reported.

$\mathrm{W}=$ Withheld . 
Unsurveyed Candidate Areas (not in order of priority)

1. Arctic (Ambler schist belt)

2. Candle

4. Nome - east

5. Farnifield

6. Boulder Creek

. Iditarod (Flat Donlin)

8. Sleetmute

9. Yentna

10. 60-Mile Butte

11. Wiseman

13. DeLong Mountains

14. Haines/Klukwan

15. Chichagof

16. Gold Hill

17. Steese/Upper Chena

18. Skwentna

19. Sheep Mountain

20. King Mountain

21. Mentasta/Slana

22. Cantwell/Windy Pass

23. Paxson/McLaren

24. Tonsina/Tiekel

25. Goodpaster

26. Tanana/Melozi

28. Yenlo Hills

29. Upper Kobuk River

30. Baird Mountains

31. Marshall

32. Delta

33. Pebble

24. Jurassic

36. Shotgun Hills

36. Shotgun Hills
37. Shaw Creek

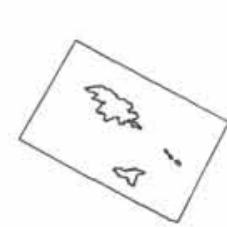

A. Circle, 1994

B. Fairbanks, 1998

C. Nome - west, 1994

D. Nyac, 1994

E. Valdez Creek, 1994

F. Richardson, 1995

G. Rampart/Manley, 1996, 1997

H. Chulitna, 1997

I. Petersville, 1997

J. Stikine, 1997

K. Ruby, 1998

L. Iron Creek, 1998

M. Koyukuk, 1998

N. Livengood, 1999

O. Fortymile, 1999

P. Ketchikan, 1999

\section{Alaska Airborne Geophysical/ Geological Mineral Inventory}

Progress as of September 1999

Lightly shaded areas indicate State Interest Lands.

Dots indicate approximate locations of candidate areas.

To date, with the support of the Administration, Alaska Legislature, the Alaska federal delegation, the U.S. Bureau of Land Management, municipalities, Native Corporations, a d the private sector, DGGS has been able to geophysically/geologically survey 17 highly prosective mineral tracts. Many other candidate survey tracts located on state investigated. Candidate lands are identified through ongoing study and communication with members of Alaska's geologic community. 

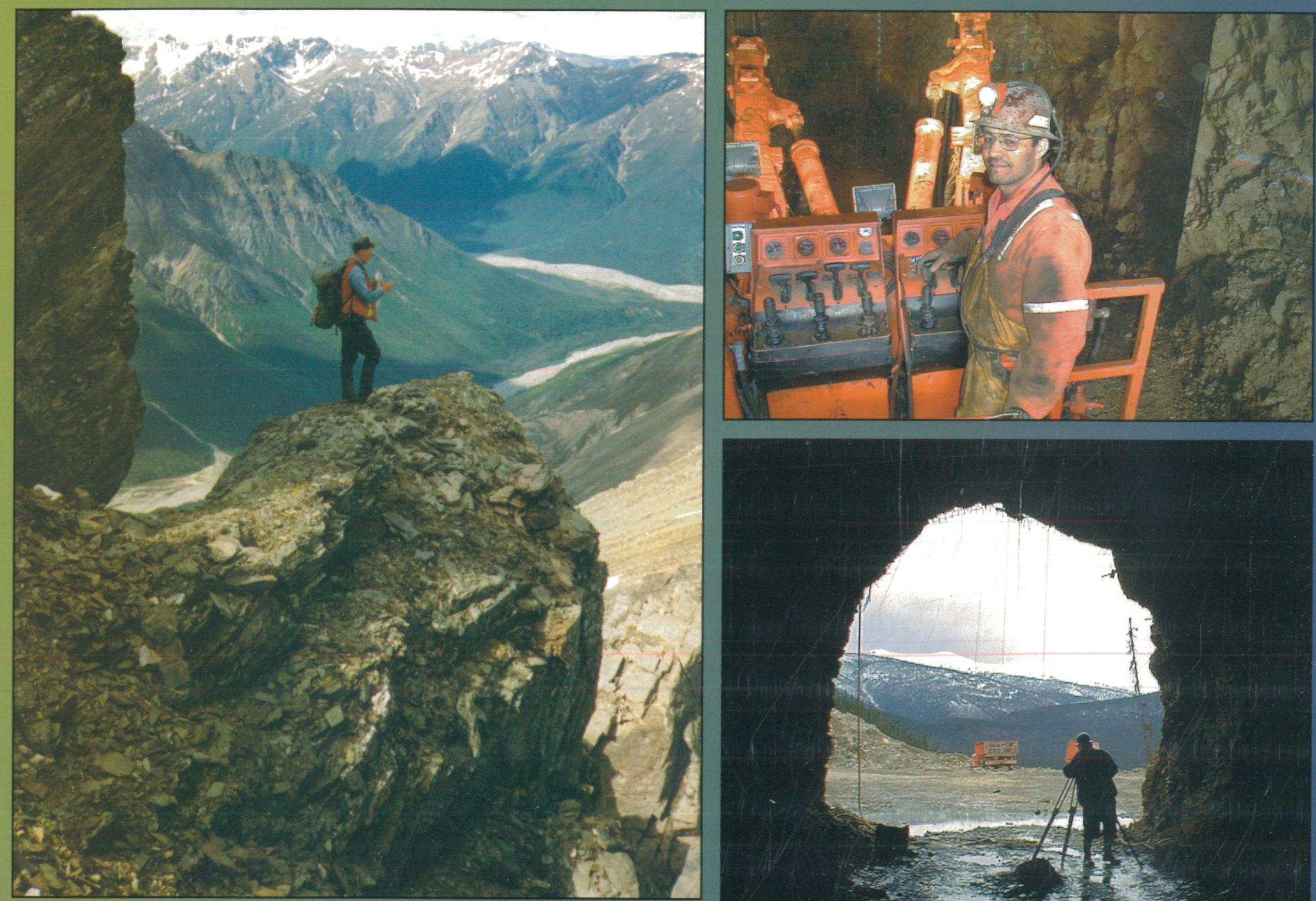

Top LEFT: Northern Associates Inc. geologist Ed Hunter mapping above Rumble Creek in the Delta Mineral Belt. (Photo provided by Sam Dashevsky) Tор Rıзнт: Angel Vilar, one of the underground miners working in the decline at Teck Corp./Sumitomo Corp.'s Pogo gold deposit. (Photo provided by Teck Resources Inc.)

Right: Pogo decline with surveyor. (Photo provided by Teck Resources Inc.) Воттом Righт: Curt Freeman examining outcropping quartz veins in the Goodpaster mining district. (Photo provided by Avalon Development Corp.) Воттом LeFT: Airborne Exploration Inc. technician observes Art Gaona adjusting drillstem on Bombardier auger drilling rig in Fairbanks district. (Photo provided by Avalon Development Corp.)
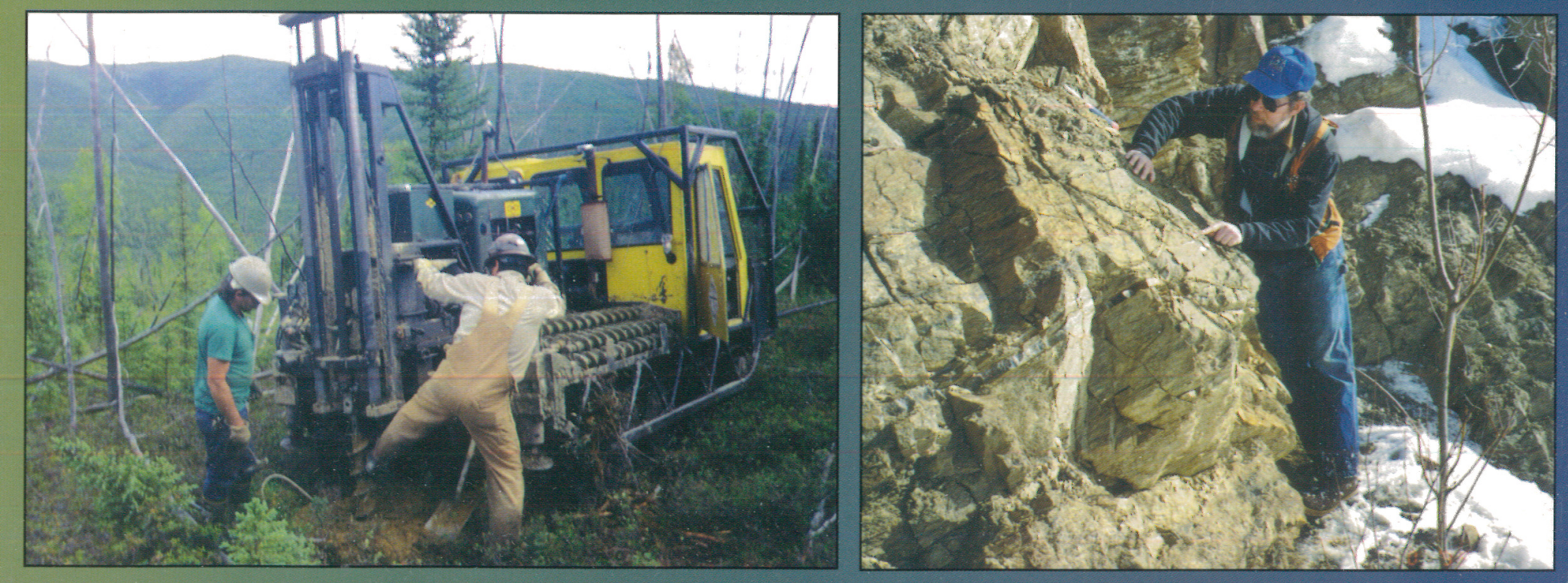